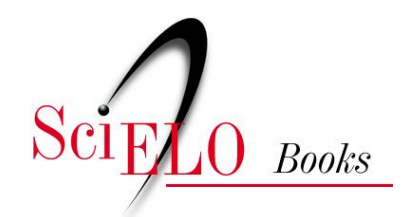

\title{
Etnografia e educação
}

conceitos e usos

\author{
Carmem Lúcia Guimarães de Mattos \\ Paula Almeida de Castro \\ (orgs.)
}

MATTOS, CLG., and CASTRO, PA., orgs. Etnografia e educação: conceitos e usos [online].

Campina Grande: EDUEPB, 2011. Autores. 298 p. ISBN 978-85-7879-190-2. Available from SciELO Books < http://books.scielo.org>.

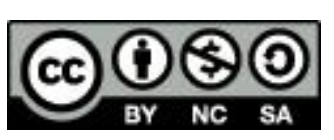

All the contents of this work, except where otherwise noted, is licensed under a Creative Commons Attribution-Non Commercial-ShareAlike 3.0 Unported.

Todo o conteúdo deste trabalho, exceto quando houver ressalva, é publicado sob a licença Creative Commons Atribuição Uso Não Comercial - Partilha nos Mesmos Termos 3.0 Não adaptada.

Todo el contenido de esta obra, excepto donde se indique lo contrario, está bajo licencia de la licencia Creative Commons Reconocimento-NoComercial-CompartirIgual 3.0 Unported. 


\section{Universidade Estadual da Paraíba}

Profa. Marlene Alves Sousa Luna

\section{Reitora}

Prof. Aldo Bezerra Maciel

Vice-Reitor

\section{eduepb \\ Editora da Universidade \\ Estadual da Paraíba}

\section{Diretor}

Cidoval Morais de Sousa

\section{Coordenação de Editoração}

Arão de Azevedo Souza

\section{Conselho Editorial}

Célia Marques Teles - UFBA

Dilma Maria Brito Melo Trovão - UEPB

Djane de Fátima Oliveira - UEPB

Gesinaldo Ataíde Cândido - UFCG

Joseilda de Sousa Diniz - UEPB

Joviana Quintes Avanci - FIOCRUZ

Marcionila Fernandez - UEPB

Rosilda Alves Bezerra - UEPB

Waleska Silveira Lira - UEPB

\section{Editoração Eletrônica}

Jefferson Ricardo Lima Araujo Nunes

Leonardo Ramos Araujo

\section{Capa}

Arão de Azevedo Souza

Comercialização e Divulgação

Júlio Cézar Gonçalves Porto

Zoraide Barbosa de Oliveira Pereira 
Carmem Lúcia Guimarães de Mattos

Paula Almeida de Castro

(Organizadoras)

\section{Etnografia e Educação Conceitos e usos}

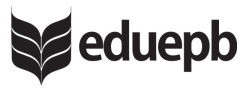

Campina Grande-PB

2011 


\section{Copyright $\odot 2011$ EDUEPB}

A reprodução não-autorizada desta publicação, por qualquer meio, seja total ou parcial, constitui violação da Lei n 9.610/98.

A EDUEPB segue o acordo ortográfico da Língua Portuguesa de 1990, em vigor no Brasil, desde 2009.

Depósito legal na Biblioteca Nacional, conforme decreto $n^{\circ}$ 1.825, de 20 de dezembro de 1907. FICHA CATALOGRÁFICA ELABORADA PELA BIBLIOTECA CENTRAL - UEPB

305.8

E84 Etnografia e educação: conceitos e usos./Carmem Lúcia Guimarães de Mattos, Paula Almeida de Castro (Organizadoras). Campina Grande: EDUEPB, 2011.

298 p.: Il.color.

ISBN 978-85-7879-088-2

1. Etnografia. 2. Pragmática do Discurso. 3.Filosofia das Ciências. I. MATTOS, Carmem Lúcia Guimarães.

21. ed. $C D D$

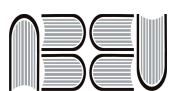

Editora filiada a ABEU

\section{EDITORA DA UNIVERSIDADE ESTADUAL DA PARAÍBA}

Rua Baraúnas, 351 - Bairro Universitário - Campina Grande-PB - CEP 58429-500

Fone/Fax: (83) 3315-3381 - http://eduepb.uepb.edu.br - email: eduepb@uepb.edu.br 


\section{Prefácio}

\section{Ao livro Etnografia e Educação: conceitos e usos}

\section{Luiz Antonio Gomes Senna}

A despeito de todos os nossos sonhos, o Século XX chegava ao fim juntamente com a famigerada guerra-fria, aquela coisa abstrata que percorreu sombriamente os horrores das duas grandes guerras mundiais e habitou o imaginário coletivo povoado por espiões, torturadores, cortinas-de-ferro e tantas outras temíveis bobagens. Ao se calarem os sonhos, toda a realidade do mundo se descortinou diante de nós mesmos e pudemos ver, perplexos, para além das ideologias revolucionárias situadas na linha de mão única entre direita e esquerda, que a maioria das pessoas do planeta sequer ingressara no Século XIX. De fato, os últimos anos do século XX foram como os de o final de uma guerra que durou um século, quando dos escombros insurgiam-se os desassistidos, os miseráveis, os excluídos, mantidos à sombra da Modernidade, bem ao estilo dos deterministas. E eram excluídos de toda espécie que, de toda parte, de súbito, faziam-se presentes, clamando por reconhecimento. Houve quem visse naqueles anos uma pós-modernidade, mas não havia nada de novo ali, embora parecessem inéditas aquelas presenças rotas por toda parte. Nem mesmo aquela terrível sensação de decepção se pudesse tomar como novidade, pois já se vivera algo similar entre os Românticos do Século XIX. Não, a dita pós-modernidade não foi mais do que uma das ideologias intelectuais daquele século já repleto de doutrinas, "ismos", paradigmas, princípios etc. O que lá se via era ela mesma, a Modernidade, enroscada em seus próprios intestinos, processando as fezes do mundo, fervendo um novo século que já se vislumbrava como o clichê da luz no fim do túnel. 
Ao fim do túnel, pouco antes de se virem as luzes do século XXI, o pensamento estruturalista - base de todo o modelo de Humanismo erigido no interior das chamadas ciências humanas - já dava sinais de estar em cheque, à medida que perdia força a crença em um sujeito ideal, estritamente lógico, a-histórico e apátrida. As correntes da Pragmática do Discurso surgidas a partir de movimentos acadêmicos da lingüística francesa entre os anos de 1960 e 1970 (no auge dos movimentos sociais que cobravam o final dos ecos da guerra-fria na Europa), não tardaram a se expandir para outros segmentos das ciências humanas. Iniciava-se aí um namoro com o homem tomado enquanto figura real, vivaz, eloqüente e, acima de tudo, social. Um homem cujos estatutos não se formulavam segundo dogmas positivistas ou religiosos, porém, segundo dinâmicas absolutamente prosaicas, casuais e medidas conforme as interações de cada qual com cada qual. E assim, DOSSE ${ }^{1}$ (1991:384), descrevendo a contribuição de Michel Foucault para a pragmática do discurso, nos explica: "o que é novo, entretanto, é o objeto dessa problematização, o sujeito, em sua relação com a ética. Nesse domínio muito clássico da filosofia, Foucault procede ainda uma vez mais à inversão da ótica tradicional, ao dissociar a moral da ética. Já não se trata de situar-se no plano dos sistemas prescritivos da moral impostos de fora e que opõem um sujeito-desejo a um código repressivo, mas de perceber os modos de produção do sujeito através da problematização da sua própria existência numa ética e estética de si".

Na pragmática do discurso, um domínio em que os sentidos do enunciado expresso se desvendam nas intenções subjacentes a cada ato comunicativo, nos termos de Jürgen Habermas ${ }^{2}$, os sujeitos não se revelam a priori, como cobaias humanas vivas, mas como fenômeno social, uma história a ser re-contada pelo pesquisador, re-significada em suas dimensões semânticas.

1 DOSSE, François (1991) História do Estruturalismo. Vol. 2 O canto do cisne, de 1967 a nossos dias. Trad. Portuguesa: Campinas: UNICAMP.

2 HABERMAS, Jürgen (1990) "Ações, atos de fala, interações mediadas pela linguagem e mundo da vida”, in Pensamento Pós-metafísico. Rio de Janeiro: Tempo Brasileiro. 
Ainda segundo DOSSE (1991: 270), "É a esfera discursiva que interessa a Foucault e não o referente, que continua sendo objeto privilegiado do historiador". Não obstante marcar o início das reformas que viriam a caracterizar a produção de conhecimento nas Humanidades mais à frente, os primeiros passos da Pragmática do Discurso ainda se apresentavam relativamente tímidos no que concerne à superação do dogma estruturalista que tomava do sujeito da pesquisa como um sujeito ideal, tal "como escreveu Habermas, nessa configuração do saber a hermenêutica é dispensada, visto que a compreensão deixou de ser o horizonte teórico de tal postura" (DOSSE 1991: 271). De fato, Habermas nos diz que "O arqueológico procederá de maneira que os documentos falantes voltem a ser monumentos mudos, devendo os objetos ser liberados de seu contexto a fim de ficarem ao alcance de uma descrição de tipo estruturalista" (HABERMAS 1988: 296) $)^{3}$.

Perpetrando, então, a mudez de seus "documentos falantes" - e lá já bem se veja como se fazem calar as pessoas por de trás dos discursos - e lhes concedendo o extrato de "monumentos mudos", a Pragmática do Discurso reveste-se de um adorável fetiche acadêmico, um exercício de formulação de juízos, ao deleite dos intelectuais que os promovessem, no aconchego de seus gabinetes ensolarados da bela Paris. Um fazer mais retórico do que agregado aos movimentos políticos que seus defensores abraçavam entre uma aula e outra. O final do Século $\mathrm{XX}$, datado propriamente junto com o final da crença numa Humanística concebida a partir de “monumentos mudos”, veria já por se consolidarem movimentos acadêmicos clamando pelo resgate do homem real, este ser histórico instituído nos sistemas de valor que se produzem e re-produzem no cotidiano e no prosaico da vida, a exemplo da teoria de sistemas de representação postulada por Sylvain Auroux ${ }^{4}$, no âmbito de uma filosofia da linguagem pós-estruturalista.

3 HABERMAS, Jürgen (1985) Le discours phisophique de la modernité. Paris: Gallimard.

4 Cf. AUROUX, S. (1979) La sémiotique des encyclopedistes. Paris: Payot. P.11. 
A emergência da uma humanidade plena de vida e voz, às portas do Século XXI, traria à cena acadêmica um problema epistemológico essencial e paralisante: a que pessoas nos referíamos nós entre aqueles recém desenterrados dos escombros da guerra fria? A superação do discurso acadêmico estruturalista, que até então determinara as bases gerais com que as Humanidades haviam definido tudo acerca do Homem, esbarrara, então, na mais primária das demandas de qualquer ciência, a saber, o conhecimento de seu objeto de investigação. Que homens haveria, então, no mundo, para além dos modelos previamente ditados nos paradigmas humanísticos da Modernidade? Eric Hobsbawm ${ }^{5}$ (2004: 504) apresenta-nos que "Nenhum período da história foi mais penetrado pelas ciências naturais nem mais dependente delas do que o século XX. Contudo, nenhum período, desde a retratação de Galileu, se sentiu menos à vontade com elas", com isto evocando a extrema dificuldade vivida naquele século para se coordenar o uso da ciência e o uso social e político da ciência. Esta desconfiança no sentido da ciência - também aplicável às Humanidades - exacerbouse entre os excluídos da esfera pública da Modernidade, ao mesmo tempo que estes ganharam espaço e ligitimidade na sociedade do Século XXI.

O plano de conflito entre excluídos, de um lado, e intelectuais, de outro, junto aos quais se formulavam as políticas públicas de governo orientadas para as minorias sociais, apresenta-se como cenário para o desenvolvimento de um ramo das ciências humanas chamado Etnografia, cujos objetos são a identificação e o registro dos sujeitos sociais situados para além dos imaginários clássicos da Modernidade. A etnografia é, portanto, a porta através da qual o pós-estruturalismo pôde vir a se tornar uma prática com verdadeiro impacto social, revolucionário, pois que vai ao povo, torna-o visível, cônscio de si e o traz para o centro da sociedade, sem máscaras, sem vergonha, sem pudores higienistas.

5 HOBSBAWM, E. (2004) Era dos extremos - o breve século XX: 19141991. S. Paulo: Cia. das Letras. 
Do mesmo modo que entre os séculos XIX e XX o pensamento estruturalista determinou a necessidade de que as ciências e as Humanidades erigissem seus próprios códigos epistemológicos, nas chamadas filosofias das ciências, as demandas epistemológicas contemporâneas sugerem a necessidade de que cada uma das ciências abrace a Etnografia como ponto de partida para si mesma. Seja partindo de uma reflexão interna no que tange aos modos e às práticas de pesquisa, assim como às dinâmicas sociais e políticas de validação do conhecimento produzido, que se realizam no domínio da realidade dos laboratórios, de formas muitas vezes inconscientes e alheias aos códigos de conduta consagrados. Seja partindo de um exercício sistemático de busca do sujeito objeto de pesquisa subjacente às pessoas investigadas, na maioria das vezes constituídas por traços fisiológicos e simbólicos não redutíveis às teorias de sujeitos previamente traçados na cultura de cada ciência. Estes exercícios de reflexão sobre as práticas de pesquisa e sobre os sujeitos de pesquisa resulta da prática etnográfica, definindo aquilo que Carmen de Mattos muito bem sintetiza como a prática de tornar o estranho familiar e o familiar, estranho. Esta definição, embasada na noção de habitus de Pierre Bourdieu, orienta todo o seu trabalho e se reflete diretamente nos textos que seguem aqui publicados.

No caminho de uma etnografia da educação brasileira, este livro nos provoca a refletir sobre a condição social da instituição escolar, numa sociedade marcada pelo profundo desconhecimento dos mecanismos que cotidianamente se empregam para perpetuar a desigualdade social. Fruto de uma aprimorada aplicação do conceito de pesquisa participante, nos termos definidos em Giddens (2001: 654-661) nidos desenham um curso de etnografia dedicado a provocar reflexão teórica e reflexão metacognitiva sobre os espaços institucionais da escola.

6 BOURDIEU, Pierre (2004) 0 poder simbólico. Rio de Janeiro: Bertrand.

7 GIDDENS, Anthony (2001) Sociologia. Tradução portuguesa: Lisboa: Fundação Calouste Gulbenkian. 
Especialmente nos dois capítulos que abrem o livro, Carmen de Mattos cuida de nos situar a etnografia no campo da Educação, dando-nos a dimensão daquilo que se pode compreender como o específico da etnografia para área acadêmica da Educação, tanto na dimensão epistemológica (no que concerne às práticas de investigação e produção de conhecimento em Educação, perpassadas por condutas etnográficas), como na dimensão histórica, neste caso, apresentando-nos uma revisão das tendências gerais que influenciaram a etnografia enquanto campo de estudos e enquanto campo de aplicação na educação. No estudo apresentado, Mattos permite-nos avançar na discussão previamente introduzida na Pragmática do Discurso, décadas atrás, porém sob a ressalva de respeito aos sistemas simbólicos reais e históricos, como clamados por Syvain Auroux, tal como expõe no capítulo A abordagem etnográfica na investigação científica: " $A$ maior preocupação da etnografia é obter uma descrição densa, a mais completa possível sobre um grupo particular de pessoas e o significado das perspectivas imediatas que eles têm do que fazem".

A perspectiva de abordagem etnográfica do fenômeno institucional escolar apresentado por Carmen de Mattos, Paula Castro e seus colaboradores neste livro apresenta-nos um salto à frente até mesmo de abordagens consagradas de questões como a do fracasso escolar. É o caso de Giddens (2001: 524), cuja abordagem, de cunho eminentemente sociológico, ainda resiste em problematizar a participação da escola enquanto mecanismo que atua sobre o comportamento do aluno oriundo das minorias sociais, tal como em "... Tal como vimos anteriormente, muitos jovens estão acrescer em condições conturbadas, com falta de orientação e apoio por parte dos adultos [... ...] Para os jovens que crescem neste cenário conturbado, as escolas podem parecer irrelevantes ou demasiado autoritárias, em lugar de constituírem um local de oportunidades e desenvolvimento". Mattos e Coelho, no capitulo Violência na escola: reconstruindo e revisitando trajetórias e imagens de pesquisas produzidas por no NetEdu entre 1992 e 2007, assim dimensionam a responsabilidade da instituição escolar sobre a violência: "Supomos que a violência não se reduz àqueles atos 
violentos visíveis aos nossos olhos, como também se esconde em ações silenciadoras, discriminadoras, de desrespeito e de humilhação, nem sempre reconhecidas como violentas [... ...] Supomos também que, nas práticas de violência escolar, docentes e alunos se antagonizam, se posicionam em disputa ou luta por autoridade, disciplina e autonomia”. É neste sentido, que os capítulos desta obra, ao buscarem provocar novos sentidos sobre as práticas institucionalizadas de educação formal, contribuem para o projeto maior da área de Educação, concernente à construção de uma escola capaz de agregar, formar e educar sem ferir os novos sujeitos sociais saídos da marginalidade pública.

Trata-se de um livro destinado ao educador contemporâneo, especialmente o que atua nos sistemas públicos de ensino, cuja meta é cumprir a Educação do povo deste país e cumpri-la de forma digna e respeitosa, mesmo diante do fato - maravilhoso fato - de que somos um país destinado à pluralidade cultural. Muito me honrou escrever o prefácio a esta obra a convite de Carmen e Paula, contribuindo, ainda que singelamente, para situá-la no contexto do pensamento contemporâneo da Educação. 



\section{Sumário}

Estudos etnográficos da educação:

uma revisão de tendências no Brasil

Carmen Lúcia Guimarães de Mattos

A abordagem etnográfica na investigação científica ... 49 Carmen Lúcia Guimarães de Mattos

A pesquisa em colaboração com

o professor: vivências de campo em

etnografia crítica de sala de aula

Carmen Lúcia Guimarães de Mattos

Imagens da exclusão na microanálise

da sala de aula: uma instância interativa

de confronto cultural

Carmen Lúcia Guimarães de Mattos

O espaço da exclusão: o limite do corpo na sala de aula.

Carmen Lúcia Guimarães de Mattos 
Uma análise etnográfica das dificuldades educacionais de alunos e alunas e do (des)controle de professores

e professoras: $\boldsymbol{c}$ mais $\boldsymbol{d}$ o que dá?

Carmen Lúcia Guimarães de Mattos

Paula Almeida de Castro

Os Ciclos e as Classes de Progressão na Rede Pública do Rio de Janeiro: percepções sobre a implementação, organização e práticas a partir das falas dos atores sociais da escola no período entre 2002 a 2004.

Paula Almeida de Castro

Tatiana Bezerra Fagundes

Carmen Lúcia Guimarães de Mattos

Programa Especial Adolescente 2007 para alunos em de 14 e 15 anos de idades: um estudo de caso etnográfico em uma Escola da Rede Pública Municipal do Rio de Janeiro.

Carmen Lúcia Guimarães de Mattos

Adriana Maria Ribeiro Gil Ferreira (anteriormente Dantas)

Violência na escola: reconstruindo e revisitando trajetórias e imagens de pesquisas produzidas por no Núcleo de Etnografia em Educação

entre 1992 e 2007.

Carmen Lúcia Guimarães de Mattos

Maria Inês de Matos Coelho

As interações de gênero e de poder em instituições de internação de jovens em cumprimento de medidas socioeducativas: um estudo etnográfico. .....221 Carmen Lúcia Guimarães de Mattos Sandra Maciel de Almeida 
Conselhos de Classe: avaliações, apreciações

e percepções sobre meninos e meninas

com implicações para as interações de gênero.

249

Daiane de Macedo Costa

Carmen Lúcia Guimarães de Mattos

O absenteísmo escolar e sua regulamentação

271

Suziane Santana de Vasconcellos

Carmen Lucia Guimarães de Mattos

Sobre os autores 



\section{Apresentação}

A pesquisa etnográfica tem sido alvo de aproximações com a abordagem sócio-antropológica e a área da educação, mais efetivamente nas últimas décadas. Nestes estudos debatia-se a possibilidade de através da etnografia ser possível dar voz aos sujeitos do fracasso, no caso os alunos em condição de exclusão e vulnerabilidade social. Entretanto, realizados no âmbito do nosso grupo de pesquisa Etnografia e Exclusão (Grpesq/CNPq) do Núcleo de Etnografia em Educação (netEDU) chegou-se ao entendimento de que mais do que dar voz aos ditos sujeitos da exclusão era preciso ouvi-los para então obter resultados de pesquisas que refletissem a percepção e a participação desses sujeitos no desenvolvimento, na análise dos dados e nos resultados da pesquisa. Este mesmo processo poderia informar sobre as políticas educacionais e, ainda, promover mudanças em suas vidas.

É com este direcionamento que os textos apresentados nesse livro pretendem informam aos leitores sobre a perspectiva da etnografia nos estudos em educação. Há que se destacar que os estudos apresentados foram realizados em escolas públicas do estado do Rio de Janeiro utilizando a etnografia tanto como um aporte teórico-metodológico quanto como um paradigma. Para compor este livro são apresentados em textos etnográficos os resultados de quatro pesquisas.

1) A pesquisa "Picturing school failure: a study of diversity in explanations of educational difficulties of difficulties among rural and urban youth in Brazil” (1989-1992) reflete um estudo sobre o fracasso escolar entre alunos com múltiplas repetências ( 3 vezes ou mais) do ensino fundamental de ensino público. Duas escolas fizeram parte do estudo: uma rural no município de Cachoeiras 
de Macacu, RJ e a outra na zona urbana da cidade do Rio de Janeiro onde a maioria dos alunos eram originários da favela da Rocinha. Utilizou a abordagem etnográfica de pesquisa com os seguintes procedimentos: observação participante, entrevistas etnográficas, documentos, redações, gravações em vídeos, dentre outros. O objetivo foi analisar as percepções dos jovens sobre as dificuldade educacionais e sobre o fracasso escolar. Fizeram parte do estudo 187 participantes: alunos, professores, políticos, diretores, orientadoras educacionais e pais. A base teórica utilizada partiu do pressuposto de que a realidade dos jovens é construída socialmente. Os resultados evidenciaram que os jovens estudados percebiam que eles próprios eram os causadores da repetência. Entretanto, um dos grupos escolheu permanecer na escola, apesar das lutas travadas em seu interior através dos múltiplos fracassos, pois acredita que a escola era um lugar onde se aprende. Outro grupo, escolheu sair da escola por achar que os professores não ensinavam e que a rua tinha mais atrativos para eles. As questões apontadas como parte do problema do fracasso escolar foram: absenteísmo de professores e de alunos; o entendimento sobre o conceito de indisciplina; a expulsão; a prática de rebaixamento de alunos oriundos de outras escolas; a falta de interesse dos professores e a falta de responsabilidade dos governos com a situação dos jovens. Os dados sugeriram que políticas educacionais mais claras e mais permanentes precisam ser implementadas como forma de minimizar o fracasso escolar de jovens e de melhorar o sistema público de ensino.

2) Fracasso escolar: imagens de explicações populares sobre dificuldades educacionais entre jovens de áreas rural e urbana do Estado do Rio de Janeiro (1992-1996) pesquisa concluída, de abordagem etnográfica que buscou ampliar dados da pesquisa de Doutorado desenvolvida por Mattos (1992). Foi realizada nas mesmas escolas que participaram da pesquisa anterior: uma urbana da rede pública do município do Rio de Janeiro, e a outra rural da rede pública deste estado no município 
de Cachoeiras de Macacu. Nesta etapa o estudo dedicouse ao fracasso escolar no interior da escola, de modo a ampliar o entendimento sobre as percepções que alunos e alunas repetentes sobre suas dificuldades educacionais. Foram acessadas ainda, as professoras, as diretoras e as coordenadoras dessas escolas. Duas professoras de $4^{\text {a }}$ série colaboram com a pesquisa e foram acompanhadas por dois anos consecutivos. Um total de 360 sujeitos fez parte da amostra. Os conselhos de classe e reuniões de professores também foram observados. Todas as observações foram acompanhadas de gravação de vídeo e áudio. Os resultados foram descritos em relatório científico circunstanciado e em trabalhos de monografia e outros divulgados em congressos e revistas científicas.

3) a pesquisa Metacognição em sala de aula: um estudo sobre os processos de construção do conhecimento na perspectiva do jovem infrator no Estado do Rio de Janeiro (1997-1999) foi parte da "Construção de Planos de Ações Socioeducativas e de Cooperação Técnica UERJ/DEGASE” (Departamento Geral de Ações Socioeducativas) viabilizado no Projeto de Excelência da Secretaria de Justiça e Interior do Estado do Rio de Janeiro. O tema da pesquisa foi a natureza da construção do conhecimento de alunos e alunas do ensino fundamental. Esse tema foi proposta pela equipe do DEGASE de modo a nortear novas políticas de atuação junto a jovens infratores que cumprem medidas socioeducativas em suas unidades. Foi investigado o entendimento que o jovem inserido no "Sistema de atendimento ao adolescente infrator no Estado do Rio de Janeiro" tem sobre seu próprio processo de construção do conhecimento e facilitação na solução de tarefas acadêmicas. Foram descritas as estratégias metacognitivas utilizadas por esses jovens dentro do contexto educacional oferecido pelo sistema. A pesquisa realizouse de acordo com a abordagem de pesquisa etnográfica, observando as forças estruturais da sociedade, como um sistema de significados mediadores entre as estruturas sociais e a ação humana. 
4) Imagens Etnográficas da Inclusão Escolar: o fracasso escolar na perspectiva do aluno (2005-2008) foi uma pesquisa etnográfica e teórica, concluída sobre o tema fracasso escolar na perspectiva do aluno. Foi realizada em um Centro Integrado de Educação Pública (CIEP1) e em duas escolas da rede municipal de ensino do Rio de Janeiro. Incluindo duas Classes de Progressão (I e II), uma classe do primeiro segmento do ciclo de formação, uma classe de 14 e 15 anos (programa adolescentes 2008/2009) e conselhos de classes realizados pelas escolas. Um total de 260 sujeitos fizeram parte do estudo. Os procedimentos de pesquisa envolveram: 1) observação participante; entrevista etnográfica com alunos professores e diretores; fotografia; redação; documentos; dentre outros. Imagens e sons do ambiente escolar, das salas de aulas e dos conselhos de classe foram registrados. Uma revisão de literatura de 863 artigos científicos sobre o fracasso escolar foi parte dos resultados da pesquisa. Artigos para congressos, dissertações de mestrado, monografias de graduação e um relatório técnico foi a produção científica do trabalho. Nestes documentos os principais temas e categorias estudadas foram: afiliação, pertencimento, identidade, diferença, violência e intolerância.

Cada uma destas pesquisas constitui um conjunto de dados que possibilitou repensar as políticas e as práticas educacionais na perspectiva dos sujeitos escolares e jovens em privação de liberdade. Pautado nessa perspectiva o livro foi idealizado com uma parte conceitual sobre a abordagem etnográfica e outra parte apresentando a pesquisa etnográfica na prática educacional.

A primeira parte divide-se em três capítulos. No primeiro capítulo "Estudos Etnográficos em Educação: uma revisão de tendências no Brasil” apresenta-se a etnografia na pesquisa qualitativa indicando seus usos, abusos, limites e possibilidades nos estudos realizados no campo educacional. O texto ainda propõe o questionamento sobre quem pode fazer etnografia. 
O segundo capítulo "A abordagem etnográfica na investigação etnográfica” explora conceitos e instrumentos da etnografia sendo reformulados para pesquisas educacionais. Ao final, propõe alguns passos iniciais a serem seguidos por aqueles (alunos, professores e pesquisadores) que pretendem realizar um estudo etnográfico.

No terceiro capítulo da primeira parte "A pesquisa em colaboração com o professor: vivências de campo em etnografia crítica de sala de aula" apresenta o relato de experiências sobre a colaboração em pesquisa entre professores e pesquisadores. O texto aponta aproximações entre a etnografia crítica de sala de aula e a pesquisa em colaboração com o professor como possibilidade genuína de ajuda mútua e intercâmbio entre o trabalho de pesquisa e o ensino.

A segunda parte divide-se em nove capítulos. Ressalta-se que os textos que compõem a segunda parte foram organizados visando ampliar as possibilidades de utilização da etnografia em pesquisas na escola, na sala de aula e em instituições de privação da liberdade. A composição dos textos envolve a apresentação do contexto da pesquisa, a abordagem teórica que dá suporte ao objeto de estudo, as análises e os resultados. Destaca-se que os estudos realizados pelo grupo de pesquisa privilegiam a apresentação dos resultados no formato de vinhetas etnográficas pelo caráter indutivo, colaborativo e teórico da triangulação dos dados no processo analítico.

Apresenta-se no terceiro capítulo "Imagens da Exclusão na microanálise da sala de aula: uma instância interativa de confronto cultural" apresenta-se como objeto de estudo a interação entre a professora Leonora (nomes de pessoas e de escolas são fictícios) e seus alunos em sala de aula, na Escola São Sebastião. Este texto centra-se na análise da interação de sala de aula, como uma fonte de dados reveladores das práticas escolares que resultam, parcialmente, em uma batalha silenciosa entre os alunos e a professora.

No quarto capítulo "O espaço da exclusão: o limite do corpo na sala de aula” são apresentadas as análises possíveis sobre a questão das dificuldades escolares entre alunos do ensino 
fundamental. As análises dos dados indicaram a organização da sala de aula como uma das formas utilizadas para desvelar as origens do fracasso escolar. Entretanto, o espaço físico e o espaço do corpo, tem sido pouco analisados no âmbito das pesquisas educacionais como fatores de exclusão social do aluno em sala de aula. Dessa forma, pretende-se demonstrar como o espaço delimita os corpos e marca a identidade social do aluno enquanto excluído do grupo-membro da sala de aula.

O quinto capítulo "Uma análise etnográfica das dificuldades educacionais de alunos e alunas e do (DES) controle de professores e professoras: C mais D o que dá?” se dedica a descrever a função de controle exercida pelo professor, através da nota, do julgamento que faz de seus alunos e alunas. Neste texto, dois aspectos do processo de controle exercido pelo professor foram estudados. O primeiro discute o controle pela nota, levantando, por um lado, aspectos sobre a coerção, a chantagem e a manipulação do professor, e por outro, a compreensão pelo aluno de que ele necessita da nota para passar de série, e que muitas vezes, não sabe como obter essa nota. Enquanto o segundo aspecto do controle discute as formas pelas quais os julgamentos e/ou objetivos pouco claros que os professores produzem sobre os seus alunos e alunas interferem no resultado acadêmico obtido por eles/as.

O sexto capítulo "Os Ciclos e as Classes de Progressão na Rede Pública do Rio de Janeiro: percepções sobre a implementação, organização e práticas a partir das falas dos atores sociais da escola no período entre 2002 a 2004" analisou aspectos da implementação, organização e práticas dos Ciclos de Aprendizagem e das Classes de Progressão a partir dos conteúdo das falas de alguns atores sociais da escola que vivenciaram estes programas compensatórios dentro da Rede de Ensino da Secretaria Municipal de Educação do Rio de Janeiro (SME/RJ) entre 2002 a 2004.

O sétimo capítulo "Classes de 14 e 15 anos: um programa compensatório de superação do fracasso escolar - um estudo de caso etnográfico" apresenta os resultados de um estudo realizado contexto de implementação das classes do Projeto 
Especial Adolescentes em 2007. Este trabalho objetivou estudar a natureza do fracasso escolas através da análise de políticas assistenciais, compensatórias e de inclusão educacional perpassando a realidade das escolas e suas diferenças.

No oitavo capítulo "Imagens de violência na escola: a negação dos sujeitos de aprender e dos sujeitos de ensinar" buscou subsidiar a reflexão sobre como a violência em diferentes formas, se insere nos processos de fracasso escolar e de exclusão, num jogo de oponentes entre a autoridade docente e a disciplina (disciplinamento/controle) dos alunos. O trabalho foi desenvolvido a partir de uma releitura de resultados de pesquisas sobre o fracasso escolar que têm sido realizadas pelo Núcleo de Etnografia em Educação no período entre 1992 e 2007, em escolas públicas de ensino fundamental no Rio de Janeiro, assim como da revisitação dos vídeos destas pesquisas.

O nono capítulo "Infração juvenil: uma questão de gênero" ilustra como a educação para jovens em conflito com a lei ainda é um desafio para os profissionais da educação. O estudo, propôs uma revisão dos dados da pesquisa Metacognição em Sala de Aula: um estudo sobre os processos de construção do conhecimento na perspectiva do jovem infrator no Estado do Rio de Janeiro (1998-2001) especificamente no que se refere às questões de gênero existentes na instituição de internação feminina acrescentando dados do estudo(MATTOS; CASTRO; ALMEIDA, 2011) para ampliar o escopo das análises.

O décimo capítulo "O absenteísmo escolar e sua regulamentação" analisou a regulamentação sobre o absenteísmo e suas implicações para o aluno, dados empíricos de sala de aula e argumentos sobre o absenteísmo entre os alunos.

O décimo primeiro capítulo "Conselho de classe não mudou em 40 anos: uma análise crítica de documentos legais e científicos - contradições e divergências entre a teoria e a prática” analisou o Conselho de Classe e sua dinâmica no processo educacional. $\mathrm{O}$ objetivo desse estudo foi fazer considerações a respeito dessa instância que surgiu no Brasil na década de 70 e que se mantém como principal instrumento avaliativo tanto em escolas da rede pública como da rede privada. 
As pesquisas que originaram os capítulos que compõem esse livro receberam financiamento da Universidade do Estado do Rio de Janeiro (UERJ), do Conselho Nacional de Desenvolvimento Científico e Tecnológico (CNPq), da Fundação Carlos Chagas Filho de Amparo à Pesquisa do Estado do Rio de Janeiro (FAPERJ) e da Coordenação de Aperfeiçoamento de Pessoal de Nível Superior (CAPES). A consolidação dos resultados desse trabalho contou com a consultoria de pesquisadores das seguintes instituições: The University of Sydney (Austrália), University of Birmingham (UK), University of Cambridge (UK), University of Pennsylvania (USA), Bielefeld University (Alemanha) University of California (Los Angeles). 


\title{
Estudos etnográficos da educação: uma revisão de tendências no Brasil ${ }^{1}$
}

\author{
Carmen Lúcia Guimarães de Mattos
}

A educação escolar, em sua complexidade, pode ser entendida como ciência oriunda do estatuto das Ciências Humanas e Sociais no qual o sujeito e objeto aparentemente se fundem. As ciências podem afirmar a prioridade epistemológica da realidade objetiva do cientista, isto é, a realidade a ser estudada existe objetivamente antes da intenção particular do pesquisador para estudá-la. Entretanto, em Educação, esta realidade estudada é cultural, assim como a do pesquisador que a estuda. $\mathrm{Na}$ dialética entre essas duas culturas, a do sujeito pesquisador e a do sujeito pesquisado, é que a complexidade se instaura e é sobre ela que se movimenta o trabalho de pesquisar. Portanto, qualquer que seja a abordagem de pesquisa, é a partir da dialética entre pesquisador e sujeito-objeto que se inicia o processo, estabelece-se as relações com o contexto a ser pesquisado, desenvolve-se o trabalho de coleta de dados, processa-se as análises e se constrói o trabalho científico.

O design de pesquisa a ser seguido é meramente uma escolha que o pesquisador exerce dentre as várias possíveis para teorizar o objeto que está examinando e, então, construir o conhecimento científico. A partir desta premissa, descrevo alguns tópicos que nos alertam sobre a abordagem de nossa escolha, que é a Etnografia.

1 Este texto foi proferido como conferência no IV Fórum de Investigação Qualitativa - III Painel Brasileiro/ Alemão de Pesquisa (2005), Juiz de Fora e parcialmente publicado na revista Educação em foco (2006). 
No primeiro tópico, decidimos iniciar por um histórico da Etnografia na Antropologia e explicar as implicações e influências que esta área trouxe à Educação em termos teórico-metodológicos, especialmente em termos da natureza de cada uma dessas áreas do conhecimento. No segundo tópico, formulamos uma pergunta a partir deste histórico - Quem pode fazer etnografia? - e tentamos respondê-la com base nos pressupostos de alguns autores. No tópico seguinte, descrevemos alguns recursos instrumentais e metodológicos concernentes a etnografia tentando analisar as implicações de seu uso na área de educação. No quarto tópico, o assunto tratado é a diferenciação entre a pesquisa qualitativa, a reflexiva e a etnográfica. No quinto tópico exploramos o que está acontecendo com a etnografia no Brasil. Neste tópico, refletimos sobre os princípios básicos que norteiam a pesquisa etnográfica e como eles têm sido aplicados nas pesquisas educacionais no Brasil, alertando para as dificuldades que têm sido enfrentadas por pesquisadores nesse campo. Dois princípios tratados são a objetivação participante (BOURDIEU, 2004) e a observação participante (SPRADLEY, 1981). Estes dois conceitos, devido à sua complexidade e similaridade, parecem confundir enormemente a tarefa de trabalho de campo. No sexto e último tópico, apresentamos as tendências da abordagem etnográfica partindo do paradoxo entre o seu uso em demasia e a sua falta de credibilidade na área educacional. Apontamos quais as possibilidades para este dilema, refletindo sobre certas preocupações e chamando a atenção dos profissionais do ensino para a necessidade de maior seriedade no treinamento e utilização da Etnografia como abordagem de pesquisa em Educação.

A partir destes tópicos, são oferecidos argumentos para o debate sobre o panorama das tendências da Etnografia na Educação no Brasil e ilustrá-las com as pesquisas que venho desenvolvendo nos últimos anos baseadas na abordagem etnográfica. Embora não esteja trazendo dados de trabalhos de outros colegas, espero que essas ilustrações nos ajudem a entender melhor o processo de construção do trabalho etnográfico, enquanto trabalho científico. 


\section{Histórico: Antropologia é Ciência? Educação é prática? Existem outras possibilidades?}

O fazer antropológico surge com a expansão do mundo através da "descoberta” pelos europeus de outros povos, cujas culturas distanciavam-se sobremaneira daquela do velho mundo.

O diferente, o desconhecido, deu margem para se fazerem questionamentos cujas respostas, segundo Gusmão (1997), "permitiram a constituição de um saber legítimo e reconhecido como ciência” (p.8). O olhar sobre o outro, entretanto, é acompanhado de diferentes formas de interpretação que, ao final do século XIX e no decorrer do século XX, caracterizam a Antropologia como sendo uma Ciência na qual os pressupostos que a orientam indicam os caminhos de busca para as respostas que se pretendem obter.

O evolucionismo então surge, no século XIX, como a primeira teoria calcada nos pressupostos antropológicos. Neste período, o homem europeu é colocado no centro e os outros grupos sociais passam a ser pensados a partir deste modelo único de humanidade. Tal forma de se compreender o outro fez com que a etnografia se caracterizasse, a partir do nosso olhar contemporâneo sobre este momento histórico, como um fazer científico discriminatório e estereotipado.

Boas (1943) inaugura uma nova corrente de pensamento sobre o fazer antropológico rompendo com a corrente evolucionista. Para este antropólogo, cada grupo possui uma história singular, dentro de sua cultura e é preciso entendê-la como parte de um momento específico; a história da humanidade pode ter seguido por diferentes caminhos, logo, o pensamento evolucionista etnocêntrico é desconsiderado.

A partir desta perspectiva, Boas (1943) critica não só os valores liberais da sociedade, baseados na ideia da evolução, mas também os sistemas e as práticas escolares, especialmente dos Estados Unidos, onde as escolas se constituíam como instituições dependentes do todo social, e cujos objetivos eram formar 
sujeitos de acordo com modelos pré-estabelecidos e idealizados, segundo a lógica dos sistemas produtivos, em detrimento da diversidade presente na própria escola e nos indivíduos. Portanto, o ideário estruturalista da sociedade liberal era criticado por Boas (1943) por ser tão discriminatório e estereotipado quanto o evolucionista.

O fazer científico antropológico passa a ser entendido também como história cultural ou culturalismo e o "trabalho de campo" ganha importância nas pesquisas que pretendiam conhecer a cultura do outro ou de si próprio. A Antropologia Cultural, vertente da Antropologia Social, emerge através do funcionalismo, representado na pessoa de Malinowski, considerado um dos pais da etnografia à medida que sistematiza os caminhos que se deve percorrer para realizar, no campo, a própria pesquisa.

Uma das formas de pensar como se realiza esse caminho e que tendências foram delineadas nessa época reside na reposta à pergunta: Quem pode fazer etnografia? A partir dos anos vinte, Malinowski (1922) preconizou que, apenas pela "observação participante”, seria possível ao pesquisador conhecer o outro em profundidade e superar os pressupostos evolutivos e o etnocentrismo (visão pela qual o homem branco europeu letrado seria superior a todos quantos apresentassem diferentes constituições, tanto físicas quanto de formas de vida e de pensamento).

Para isso, a etnografia deveria ser uma pesquisa intensiva, de longa duração: o etnógrafo precisaria viver no local, aprender a língua nativa e, sobretudo, observar a vida cotidiana. O pesquisador deveria dar conta da totalidade da vida da tribo observada, a partir da constituição da sociedade, da vida real e do espírito do nativo. Diferente desta concepção é o chamado paradigma hermenêutico, no qual se assentaram os pós-modernos em sua defesa da polifonia, ou seja, da necessidade de dar voz ao participante. Geertz (1978) sustentará que a cultura deve ser vista, antes de tudo, como uma "teia de significados que o próprio homem teceu" e a tarefa da antropologia é realizar o desvelamento desta cultura. Se a cultura precisa ser 
interpretada, não é possível aceitar que o seja a partir de um só olhar ao qual o estatuto da ciência confere maior autoridade. Os pós-modernos não aceitam mais a ideia desta autoridade soberana e passam a ter, como objeto a ser desconstruído, o próprio texto etnográfico e a relação de poder do pesquisador em relação aos pesquisados. É bem verdade, porém, que no rol das boas intenções (autocrítica que atinge o caráter colonialista e dominador do etnógrafo dos países ricos), encontram-se práticas questionáveis. Ao propor a revisão da etnografia, ao propugnar a multiplicidade das vozes, desviou-se a polêmica da disputa teoria versus prática para uma disputa no interior do registro da pesquisa, o que favoreceu um certo rebaixamento da própria qualidade da pesquisa, tal perspectiva é bem discutida por Peirano (1995).

Nos anos 30, a antropóloga M. Mead fez da Educação objeto privilegiado da Antropologia no interior da escola. Sua obra clássica, intitulada "Growing up in New Guinea" (1931), buscava entender de que forma valores, gestos, atitudes e crenças eram inculcados nas crianças pelos adultos com o objetivo de formálas para viver dentro da sua sociedade. Esta pesquisadora investigou tanto os modos de transmissão das gerações mais velhas para as mais novas, como a própria formação da personalidade e as formas de aprendizagem existentes na escola. Esta abordagem analisada por Dauster (1997) revelava as especificidades culturais travando um diálogo com a psicologia e a psicanálise tendo em vista sustentar a existência de "personalidades culturais" no interior da escola.

André (1997) sustenta que, o interesse dos pesquisadores, a partir da década de 70, está em estudar as questões relacionadas à integração na sala de aula — interação professor - aluno - e aos métodos de avaliação educacional - habilidades de ensino junto aos docentes. Estes são temas recorrentes nos estudos etnográficos em educação neste período. No campo da Educação, encontramos também as tendências aos estudos etnográficos diagnósticos, os etnohistoriográficos, que ganham muita força até os dias de hoje, assim como os etnomatemáticos. 
Nos anos 80, ainda segundo André, a abordagem etnográfica ganhou muita popularidade, inclusive na área educacional. Nesta década, foram desenvolvidas teses e dissertações que descreviam as atividades em sala de aula e as relações construídas diariamente neste espaço educacional.

Um outro enfoque localiza-se na vertente da escola sociológica francesa. Pierre Bourdieu (2004) trabalha a noção de habitus tendo em vista o processo educativo que, por intermédio de sua teoria, surge de forma dinâmica como inculcação de disposição durável, matriz de percepções, juízos e ações que configuram uma razão pedagógica, ou seja, a lógica e a estratégia que uma cultura desenvolve para transmitir seus valores.

Na atualidade, a etnografia, no campo da antropologia, não pretende "tornar familiar o exótico" cuja exoticidade, mas que intrigar ou atrair, objetiva fazer o leitor pensar: "eu nunca tinha pensado que a etnografia significasse isso ou que desse margem a essa interpretação”. Essa ideia se aproxima do procedimento mencionado por Da Matta (1978), que seria o de tornar exótico o familiar. Trata-se de adotar um recurso metodológico de estranhar, distanciar-se das regras, da visão de mundo e das atitudes legitimadas pela sociedade e por suas instituições, tirando estas da opacidade em que a cultura as coloca.

De acordo com Novaes (1992), a Antropologia e a Educação possuem uma relação desafiante que se articula pelos projetos singulares que apresentam. A primeira, pelo "projeto antropológico do conhecimento das diferenças" e a segunda, pelo "projeto educacional de intervenção na realidade". Nesses sentidos, o pensamento de Novaes (1992) concorre com o de Boas (1943) sobre o fazer antropológico.

Antropologia e Educação hoje, segundo Gusmão (1997), parecem constituir um campo de confrontação no qual o compartilhamento do saber atribui àquela a condição de ciência e a esta a condição de prática. Dentro desta divergência primordial, os profissionais de ambos os lados se acusam e se defendem com base em pré-noções, práticas reducionistas e muita falta de conhecimento. Se há muitas coisas que nos 
separam - antropólogos e educadores —, há muitas outras que nos unem. O que nos une é anterior ao que nos separa e nele se inscreve o diálogo do passado, tanto quanto a possibilidade do diálogo do futuro.

Buscando responder a pergunta - Quem pode fazer etnografia? -, diria que qualquer pesquisador culturalmente sensível pode fazê-la, embora minha resposta aos meus alunos seja: aquele que sente um grande desconforto na boca do estômago com algo que não vai bem na sociedade e que não passa por ele muito facilmente, isto é, se algum fenômeno social está “caindo mal” para você, este é o seu objeto de estudo. Portanto, qualquer pesquisador bem treinado em etnografia e com uma pergunta socialmente relevante deve fazer pesquisa etnográfica. Como fazê-la? Só o pesquisador ou pesquisadora pode responder a este questionamento através do campo, pois cada campo é único, cada pesquisa é única e cada dia na própria pesquisa é único.

\section{Recursos etnográficos e as implicações de seu uso}

A partir dos anos 80 e até os dias atuais, alguns instrumentos etnográficos passaram a ser frequentemente utilizados em pesquisas educacionais, por isso vale a pena citar alguns, são eles: observação participante, entrevista, imagens de vídeo, história de vida, questionários, dentre outros.

Decorrentes desses tipos de coleta, podemos apontar algumas formas de análises: análises indutivas, microanálise etnográfica, análise de contexto, análise de discurso, análise sociolinguística, análise documental, análise histórica, análise representacional, análise cultural, análise hermenêutica e análise crítica.

Com relação às maneiras que estes trabalhos são relatados, podemos encontrar as mais variadas nuances que vão desde processos narrativos livres com simples descrições de falas sobre o que os participantes dizem, até fotografias com análises detalhadas de representações e significados para pesquisadores e pesquisados. Quanto aos relatórios das análises 
de contextos e de discursos, pode-se dizer que estes muitas vezes se misturam, como se seus procedimentos descritivos tivessem as mesmas origens e processos. Os relatórios históricos e documentais, por sua vez, distanciam-se das vinhetas etnográficas enquanto entidades próprias pertencentes a um corpo teórico-metodológico-epistemológico separado dos dados etnográficos.

As análises sociolinguísticas, geralmente associadas às interações de sala de aula, pertencem a um grupo raro que quase sempre respeita as análises culturais e os processos analíticos indutivos, desenvolvendo relatórios e descrições etnográficas e microetnográficas, na maioria das vezes, apropriados em termos etnográficos.

A crítica que podemos fazer aos procedimentos mais frequentes em pesquisas que se intitulam etnográficas são: em primeiro lugar, o uso indiscriminado e individualizado de instrumentos sem o devido cuidado e treinamento do pesquisador e de sua equipe e, em segundo lugar, o processo de análise geralmente o pesquisador não leva em conta a voz ou a presença do participante na pesquisa e no relato final do trabalho.

O lugar de onde o pesquisador fala é do seu próprio lugar e não daquele do pesquisado, isto é, ele fala sobre o pesquisado e não com ele. Este fato cria um fator anulador da opção pela abordagem etnográfica, pois nesta abordagem o pressuposto maior é que o lugar do participante é como agente da pesquisa. Portanto, como avaliar, analisar ou relatar uma pesquisa a partir da sua experiência e não da experiência do outro, se o outro é o seu objeto-sujeito da pesquisa?

Uma dos instrumentos que parecem vir para ficar é a etnografia visual (uso de vídeo, TV, jornais, fotografia, pinturas, imagens em geral) auxiliada pelo uso do microcomputador. $\mathrm{O}$ uso de vídeo ganha cada vez mais espaço como instrumento recorrente na pesquisa de um modo geral e, particularmente, na pesquisa educacional, especialmente na coleta de dados no contexto escolar. Seu objetivo é contribuir para um maior entendimento das ações ocorridas em um evento interativo. (MATTOS; CASTRO, 2004). 
As cenas rotineiras tornam-se, por vezes, invisíveis às observações comuns da etnografia, isto é, os instrumentos por ela utilizados para coletar e analisar os dados - imagem — surgem como alternativa para tornar mais visíveis as rotinas a serem estudadas, além de permitir, tanto ao pesquisador quanto aos participantes da pesquisa, a tomada de consciência sobre a necessidade ou não de uma mudança de rotina (ERICKSON; SCHULTZ, 1977).

O vídeo possibilita observar e (re)observar um evento no momento de sua ocorrência, ao passo que a observação única pode deixar escapar algum detalhe na interação da cena ou do evento em estudo. Além disso, serve como contraponto quando da comparação com as anotações de campo (PINK 2001).

No que diz respeito ao uso de computadores nas Ciências Sociais, pode-se inferir que este uso tem crescido rapidamente e a etnografia, enquanto abordagem de pesquisa utilizada em tais ciências, participa deste processo (DELAMONT, 1992; Agar, 1983).

Os métodos de análise têm se beneficiado com este uso, sobretudo a análise de conteúdo, através de inúmeros softwares que fazem o levantamento cruzado de categorias temáticas que culminam com tendências que favorecem as análises indutivas.

$\mathrm{Na}$ análise indutiva, partimos de dados particulares para o geral e, através de objetivos ou afirmações argumentativas, ampliamos o foco das análises para um universo mais generalizado, formulando premissas universais típicas ou atípicas que podem ser comprovadas e sustentadas através dos dados e das teorias formando assim a base do conhecimento que está sendo construído ou relatado como resultante da análise.

Nos Estados Unidos, Inglaterra e França utilizam-se largamente, e com bastante êxito, esses softwares, o que agiliza o árduo trabalho de análise, especialmente quando o campo é realizado por um longo período de tempo e o acervo de dados é grande, o que é comum em quase todas as pesquisas etnográficas (AGAR, 1983; MASON, 2005). 
O volume de dados e de transcrições manuais tem sido reduzido pelo uso de gravadores digitais que copiam textualmente as vozes para o computador com pequenos erros. O uso de softwares faz com que o levantamento de frases e palavras reincidentes no texto escrito diminuam o tempo de análise e de relato e de dados de modo significativo, facilitando a análise de conteúdo e a categorização de dados.

No Brasil, esses softwares ainda são poucos e estão sendo elaborados por equipes de sociolinguístas, com pouca participação da área de educação até por conta da escassez de financiamento em nossa área (MASON, 2005).

\section{A etnografia na pesquisa qualitativa}

Para entendermos as tendências na etnografia, temos que pensar nas dúvidas que pairam sobre os temas: pesquisa educacional, pesquisa reflexiva (pesquisa-ação ou pesquisa sobre a própria prática) e pesquisa etnográfica.

Vou utilizar uma caracterização realizada por Sara Delamont (1992) para refletir sobre esse debate. Ela elenca três tipos de pesquisa - a qualitativa, a reflexiva e a etnográfica - e, através dos instrumentos utilizados por cada uma delas, classifica-as.

Na pesquisa qualitativa, geralmente, utilizam-se recursos como: entrevistas (com perguntas abertas e fechadas), história de vida, entrevista oral, estudo pessoal, mapas mentais, estudos observacionais, observação participante ou não.

A pesquisa reflexiva, por sua vez, envolve a autoconsciência. Significa dizer que o pesquisador reconhece e termina o ciclo da interação e da percepção que caracteriza as relações com outros participantes da pesquisa durante a mesma. Geralmente este tipo de pesquisa se dá através da colaboração entre pesquisador e participantes ou quando o pesquisador pesquisa a sua própria prática. 
Hammersley (1992); Delamont (1992) e Atkinson (1982) descrevem em seus trabalhos a natureza reflexiva da pesquisa, sendo a autoconsciência um conceito central e relevante, não só no processo de coleta e análise de dados, como também na construção do texto. Neste, o pesquisador precisa deixar explícito questões de validade e fidedignidade.

A pesquisa etnográfica inclui todos os recursos das anteriores e mais, necessariamente, a observação participante, o participante como protagonista da pesquisa, a imersão na cultura local por prolongado período de tempo, a busca por eventos típicos e atípicos e a análise por processos indutivos.

Concluindo, parece fácil reconhecer a pesquisa qualitativa, mas destacar dela a etnografia é uma tarefa que exige olhos exigentes e perspicazes. Entretanto, as metodologias ou os procedimentos não qualificam ou desqualificam uma pesquisa, o que o faz é a rigorosidade, o compromisso, a relevância científica e social, a capacidade do pesquisador em proceder e comunicar aquilo que fez e o que resultou do seu fazer científico.

Em etnografia, o que buscamos é que esta abordagem, mais que um design de pesquisa, se torne um paradigma científico de contorno epistemológico-científico.

Para Delamont (1992), como para nós, as dificuldades em se reconhecer a pesquisa etnográfica ou os seus elementos básicos parece originar-se do pouco treinamento dos pesquisadores.

Em nosso entendimento, o domínio de uma técnica não garante uma pesquisa. A etnografia, como as demais abordagens de pesquisa, pertence a um campo teórico-epistemológico que precisa ser compreendido para que possa ser utilizado pelo pesquisador. No campo da sócio-antropologia e/ou da sociologia da educação, podemos afirmar que existe uma atração entre as áreas de exclusão social e as pesquisas etnográficas, isto é, o "etnoe", que é um radical grego que significa o outro, escrever sobre o outro, mas na perspectiva dele. 


\section{O que está acontecendo hoje com a etnografia educacional?}

Uma reflexão que nos parece importante sobre a abordagem etnográfica de pesquisa no Brasil diz respeito ao desconhecimento dos pesquisadores sobre os princípios básicos da etnografia, à falta de clareza sobre o papel da teoria na pesquisa, as dificuldades existentes em lidar teórica, metodológica e epistemologicamente com as questões da objetivação participante e da observação participante (BOURDIEU 2004), e ainda faltando ao pesquisador desenvolver um olhar relativizador de que nos fala André (1986 e 1995), Dauster (1994, 1997) e Rockwell (1980). Tais pontos podem não só comprometer, mas inviabilizar pesquisas educacionais de base etnográfica.

A partir destes pressupostos, passo a explicitar os princípios básicos considerados necessários ao desempenho da tarefa do etnógrafo educacional e que algumas vezes são desconhecidos ou ignorados pelo pesquisador.

O primeiro deles é a descrição densa (GEERTZ, 1978). Este tipo de descrição foca a cultura local sem perder a especificidade do particular mas retornando sempre ao geral ou à totalidade do evento ou da cena estudada.

O segundo ponto é a clareza sobre o papel da teoria na pesquisa. As tensões provocadas pela entrada da etnografia no campo da pesquisa educacional culminaram no descrédito das práticas etnográficas na educação, atribuídas especialmente à fragilidade do processo de validação científica e ao reduzido número da amostragem que fragilizaram também suas bases teóricas. Nesse território de descrédito, a utilização do método indutivo de análise, próprio da etnografia, dá pouca margem à comprovação de teorias já testadas e comprovadas em contextos diversos daqueles da pesquisa que está sendo realizada no momento. Diferentemente de uma pesquisa cujo aporte se dá a partir de conceitos previamente determinados e teorias previamente construídas e selecionadas, a etnografia, pelo seu método de análise indutiva, dificulta o processo de se aliar as teorias educacionais mais conhecidas à sua prática de pesquisa (MATTOS, 2004; ERICKSON, 1992; ROCKWELL, 1980). 
Em etnografia, os dados ditam o caminho teórico a ser conduzido durante as análises e os resultados da pesquisa, suas hipóteses vão sendo construídas progressivamente à medida que os dados respondem ou não às perguntas que os agentes de pesquisa, junto com o pesquisador, formulam diante do objeto pesquisado.

Entendemos que a prática de pesquisa etnográfica, assim como a de quaisquer pesquisas, não é a priori despida de qualquer fundamentação teórica e/ou metodológica. A própria escolha do objeto de estudo pressupõe estudos anteriores que levem o pesquisador a entender o campo a partir de um olhar que foi construído ao longo de sua experiência de vida.

Nesse sentido, a relação entre a teoria e a etnografia é caracterizada como uma relação imbricada na qual não é possível uma distinção. Assim sendo, poderíamos chamar essa não separação de práxis na pesquisa etnográfica.

O terceiro princípio a ser respeitado pelos etnógrafos educacionais refere-se à objetivação participante (BOURDIEU, 2004) e à observação participante (SPRADLEY, 1981). A proximidade do pesquisador com o objeto de pesquisa e sua aderência a ele resultam na dificuldade de se objetivar o objeto de pesquisa, de olhá-lo com o distanciamento necessário do seu campo de inserção, como por exemplo, o diretor em seu campo de atuação, o orientador pedagógico em seu trabalho de orientação. Para Bourdieu:

[...] 'a objetivação participante’ (e que é preciso não confundir com a "observação participante”, análise de uma - falsa - participação num grupo estranho) é sem dúvida o exercício mais difícil que existe, porque requer a ruptura das aderências e das adesões mais profundas e mais inconscientes, justamente aquelas que, muitas vezes, constituem o «interesse» do próprio objecto estudado para aquele que o estuda, tudo aquilo que ele menos pretende conhecer na sua relação com o objeto que ele procura conhecer. [...] o trabalho de objetivação incide neste caso 
sobre um objeto muito particular, em que se acham inscritas, implicitamente, algumas das mais poderosas determinantes sociais dos próprios princípios da apreensão de qualquer objeto possível [...] (2004, p. 51).

Em etnografia, a objetivação participante é a compreensão objetiva que o pesquisador tem do objeto e que passa a ser parte do seu universo concreto de observador.

Suponhamos que um pesquisador não tenha entrado em uma sala de aula nos últimos trinta anos, a objetivação participante que ele fará desta sala de aula e sobre o aluno presente na mesma é representada pela imagem de aluno que ele tem a partir de si próprio e não daquela que, através da observação participante, ele pode livre e despretensiosamente acessar, mediante o tempo no campo.

Portanto, a observação participante é, na visão de Erickson (1986), de outra natureza. Segundo ele, a natureza da observação participante é indicada pelo próprio nome do método, é a participação ativa com aqueles que são observados. A participação do pesquisador pode variar ao longo de uma continuidade, com a participação mínima envolvendo, em primeiro lugar, a sua presença durante os eventos que são descritos e a máxima participação envolvendo as ações do pesquisador quase como qualquer outro participante da pesquisa o faz nos eventos que ocorrem enquanto o pesquisador está presente. $\mathrm{Na}$ extremidade desta continuidade, a única diferença entre a participação do observador participante e de qualquer outro membro é que o observador participante atenta fortemente para não influenciar o curso que os eventos podem tomar. Um observador participante tenta ver os eventos dos quais ele participa do ponto de vista do relativismo cultural, tentando não fazer julgamentos finais e tentando entender os eventos como eles acontecem do ponto de vista dos vários atores e através dos valores dos mesmos. A posição de relativismo do observador é difícil de manter. Talvez ele nunca seja bem sucedido nisto, porém o mais importante na observação participante é tentar entender os eventos e as pessoas adotando os papéis e as perspectivas daqueles que se estuda (ERICKSON, 1986). 
A observação participante, portanto, em um ambiente pedagógico, como a sala de aula e o conselho de classe, por exemplo, exige simultaneamente do pesquisador uma atenção ampliada e particular. Essa participação parece, a priori, impossível. A participação limita o foco de atenção devido ao filtro cultural do pesquisador e isso vai dar o tom da pesquisa, da análise e da interpretação dos dados. O pesquisador dá mais atenção ao que lhe é mais familiar e de maior interesse.

A objetividade da pesquisa pode ficar comprometida, nesses casos, pela falta de distanciamento do investigador do objeto a ser estudado. A ideia de participação causa uma certa dificuldade na medida em que não estão claros os papéis a serem desempenhados pelos pesquisadores e pelos participantes da pesquisa. Portanto, deve-se estar alerta para a dialética entre a objetivação e a observação do objeto.

Esses pontos considerados críticos nas práticas de pesquisas etnográficas, apesar de constituírem um arcabouço relevante para pensarmos as pesquisas que têm sido realizadas utilizando a etnografia, não dão conta de explicar os problemas que nelas se apresentam.

Gostaria de levantar alguns outros pontos que nos auxiliem a desvelar o que tem ocorrido nos estudos "etnográficos". Chama-me a atenção a maneira inadequada como pesquisadores na área da educação têm-se apropriado dos instrumentos de pesquisa etnográficos e da etnografia mesma, e os têm ressignificado sem, contudo, cuidar para que essa ressignificação não se torne um simulacro da abordagem teórico-metodológica etnográfica.

Muitas vezes, a desculpa de se preservar a identidade do educador e a do pesquisador da área educacional, sobretudo nos estudos por eles realizados, tem resultado em prejuízo no que diz respeito à qualidade das pesquisas.

Não quero com isso desacreditar ou diminuir a importância dos trabalhos realizados por pesquisadores na utilização da abordagem etnográfica, mas alertá-los para a necessidade de utilização rigorosa e cuidadosa que caracterizam um trabalho científico. 
A observação participante, a narrativa, a entrevista, o vídeo, o áudio, a transcrição literal de falas, entre outras técnicas estão presentes, como já dito, nas pesquisas qualitativas de cunho etnográfico. Contudo, não estão sendo respeitadas as práticas de triangulação de dados e os cuidados necessários nos processos de análise que toda etnografia prevê, em especial o tempo no campo, a descrição densa e a análise indutiva, características que herdamos da antropologia e que, de certa forma, garantem a fidedignidade e a validade dos dados analisados.

A apropriação de recursos etnográficos, tanto pelos usuários dos métodos qualitativos quanto dos métodos quantitativos na área educacional, leva-nos a crer que, nos últimos anos, esta abordagem tem trazido, por um lado, uma contribuição para ampliar as formas de investigação nesta área. Por outro lado, percebe-se que esta ampliação está se dando de forma indiscriminada devido aos abusos na utilização das técnicas etnográficas de pesquisa.

\section{As tendências: encaixes e desencaixes de fichas simbólicas}

É sobre o paradoxo existente entre a possibilidade de a etnografia poder vir a ser um efetivo instrumento de contribuição para as análises dos processos educacionais e a de ela cair em desgraça acadêmico-científica e ser execrada no campo educacional e, quem sabe, devolvida para o seu campo de origem como a pior das "técnicas" que surgiu no campo da educação que pretendo focar a minha fala.

Acredito que é no equilíbrio dessas forças paradoxais que entraremos num acordo. Entretanto, para efeito didático, como nos diria meu mestre Paulo Freire, vamos exercitar dialeticamente esses opostos divergentes. Pois, não podemos falar que a etnografia tem sido totalmente mal usada em educação, tampouco que por estar sendo muito utilizada, ela será uma das maiores tendências em pesquisa educacional desta década. É no meio que, às vezes, encontramos equilíbrio. 
Pensando neste equilíbrio, convoco a parceria de Anthony Giddens (1991), sociólogo inglês que nos falou sobre as consequências da modernidade e no alívio que sentimos na sensação de uma segurança ontológica que a modernidade nos oferece, na qual, entre o equilíbrio do risco e da confiança, nós construímos mentalmente a segurança ontológica para justificar escolhas e eliminar dúvidas, inclusive sobre os processos de construção do conhecimento. Assim, podemos explicar como é possível alguns pesquisadores escolherem as técnicas de práticas etnográficas sem associá-las às teorias que as pressupõem e ficarem satisfeitos com seus resultados, certos que, por ser a natureza da educação de predominância prática, justifique-se essa escolha e esses resultados.

Lançamos mão mais uma vez de Giddens (1991), mas, desta vez, fazemos referência à sua teoria sobre as fichas simbólicas. Estas são como mecanismos de desencaixes intrinsecamente envolvidos no desenvolvimento das instituições sociais modernas e que significam intercâmbios entre indivíduos e grupos que lidam com qualquer situação particular para legitimar um evento, uma ação, uma política ou uma forma de agir. A partir deste conceito, podemos significar que o uso da etnografia em educação pode ser uma forma de legitimação de uma abordagem de pesquisa que se adeque a essa área em particular.

O seu uso em demasia pode significar uma política de opção por uma linha teórico-metodológica e portanto o desencaixe de uma ficha simbólica da modernidade para a área educacional.

No meio acadêmico, se dependemos de dados para proceder às análises, devemos encontrar meios para obter esses dados. Os meios estatísticos há muito tempo deixaram de ser a melhor escolha para os pesquisadores educacionais. Eles sempre serão o ponto de partida, um auxílio seguro, um veículo de informação geral, mas é no particular que estamos garantindo os nossos projetos e as nossas práticas. As atuais escolhas recaem sobre técnicas que nos lembram as utilizadas por veículos midiáticos, uma vez que, em nossos cursos de pós-graduação, a relevância maior é dada aos princípios teóricos dos estudos acadêmicos em detrimento dos paradigmas metodológicos de pesquisas, salvo raras exceções. 
Certos de que precisam prover suas teses e dissertações de dados científicos e certos ainda de que o campo da educação é preponderantemente um campo da prática pedagógica, os pós-graduandos buscam nos instrumentos etnográficos, meios úteis e ligeiros de obtenção dos dados de que necessitam. Transcrevem seus vídeos, seus áudios, suas notas de campo e analisam seus escritos baseados nas teorias que orientaram seus longos períodos de estudos teórico-acadêmicos. Sem muita cerimônia, não raro no próprio título, assinalam a metodologia etnográfica como base para a coleta, análise e interpretação dos dados.

Nos encontros educacionais dos quais tenho participado, sobretudo nos quatro últimos anos, pude verificar que um grande número de trabalhos se declarava de cunho etnográfico, pois utilizavam entrevistas e vídeos como instrumento de coleta, mas foram realizados em um curto período de tempo.

São esses tipos de trabalhos que recheiam os anais de congressos pelo país e as prateleiras dos cursos de pós-graduação e graduação que servem à nossa indagação. Será que o tão relevante uso dos instrumentos etnográficos irá fazer com que os cursos de pós-graduação passem a adotar essa disciplina em suas grades curriculares e realmente instrumentalizem os alunos com ferramentas menos aligeiradas e mais consequentes em termos de rigorosidade, validade, fidedignidade e /ou simplesmente de procedimentos adequados em termos básicos da etnografia?

Concomitantemente, a overdose de uso da etnografia no campo da educação leva também ao desgaste de seu uso frente a outros campos do conhecimento. Aos olhos, já suspeitosos, da filosofia, da história, da sociologia, da psicologia, entre outros campos da área das Ciências Humanas, parece que não sabemos mais fazer pesquisa, apenas relatos e descrições de falas distanciadas de teorias que não refletem a produção de conhecimento esperada de um trabalho científico.

Neste sentido o uso inadequado; a negligência com alguns procedimentos básicos de coleta, análise, interpretação e relato de dados; a falta de treinamento específico em relação aos 
pressupostos teórico-epistemológico-metodológicos da etnografia levam os pesquisadores em Educação menos avisados a realizarem uma pesquisa de baixa qualidade.

A evidência maior está no processo de análise no qual não é declarada a forma como os dados foram validados através de processos indutivos e de triangulação. Fica evidente ainda, pela ausência de sustentação teórica nas afirmações das categorias evidenciadas nas análises, que o processo não se desenvolve como definem as teorias sobre etnografia em sua maior parte desenvolvidas pelos pesquisadores. Muitas vezes, os dados são apenas narrados como se isso representasse a verdade dos fatos e a interpretação não passa de uma ingênua referência confirmando o que o informante declarou ao pesquisador (BORTONI, 2001, p.133).

Outra evidência da banalização do uso de instrumentos etnográficos é a utilização de vídeo para evidenciar hipóteses preconcebidas sobre as questões socioeducacionais relacionadas à realidade socioeconômica das comunidades como fator interveniente no processo educacional. 0 fato de o vídeo ser uma prova imagética da pobreza e da miséria não comprova a natureza pobre e miserável do conhecimento dos meninos e meninas dessa comunidade. $\mathrm{O}$ uso genérico do vídeo, que pode levar a procedimentos imperdoáveis no meio acadêmico, tem servido de exploração para muitas solicitações de financiamento no Brasil e até no exterior sem que a obtenção de suporte financeiro seja transferida como benefício para as populações-sujeitos da pesquisa. Portanto, fica o alerta para que a vulgarização do uso dos instrumentos etnográficos em nome da pesquisa de abordagem etnográfica não acabe por fazer implodir uma forma digna e eficiente de se conduzir um trabalho científico de pesquisa simplesmente porque alguns, por desconhecimento, não a utilizam com a dignidade e treinamento que ela merece.

\section{Considerações Finais}

Etnografia é teoria, educação é teoria. Aplicamos técnicas em ambas conforme suas especificidades enquanto abordagens de pesquisa e enquanto áreas do conhecimento. Entretanto, tanto quanto na psicologia, na sociologia, na antropologia, podemos 
buscar nas duas, através da pesquisa, a dialética entre sujeitoobjeto, a abordagem de pesquisa, o campo de conhecimento e ainda, através dos dados, das análises e das categorias construídas com rigorosidade científica e devidas construções epistemológicas, sustentar formulações teóricas de igual ou melhor qualidade do que qualquer outra das Ciências Humanas.

Considero, mais uma vez, oportuno recorrer a Paulo Freire e à reflexão sobre a utopia, que ele escreveu antes de morrer, em 1997.

Seres programados para aprender e que necessitam do amanhã como o peixe da água, mulheres e homens se tornam seres roubados se se-lhes nega a condição de partícipes da produção do amanhã. Todo amanhã, porém, sobre que se pensa e para cuja realização se luta implica necessariamente o sonho e a utopia. Não há amanhã sem projeto, sem sonho, sem utopia, sem esperança, sem o trabalho de criação e desenvolvimento de possibilidades que viabilizem a sua concretização. É neste sentido que tenho dito em diferentes ocasiões que sou esperançoso não por teimosia, mas por imperativo existencial. É aí também que radica o ímpeto com que luto contra todo fatalismo. Não faço ouvidos de mercador ao discurso fatalista de educadores que em face dos obstáculos atuais ligados à globalização da economia reduzem a educação a pura técnica e proclamam a morte dos sonhos, da utopia. Se já não há classes sociais, portanto seus conflitos, se já não há ideologias, direita, esquerda, se o desenvolvimento não tem nada que ver com a política, mas com a ética, a do mercado, malvada e mesquinha, se a globalização da economia encurtou o mundo, se o mundo ficou mais ou menos igual, cabe à educação o puro treino ou adestramento dos educandos. Recuso esse pragmatismo reacionário tanto quanto o discurso acomodado que fala dos famintos brasileiros ou dos desempregados do mundo como uma fatalidade do fim do século. 
O meu discurso em favor do sonho, da utopia, da liberdade, da democracia é o discurso de quem recusa a acomodação e não deixa morrer em si o gosto de ser gente, que o fatalismo deteriora (FREIRE, 2001, p.85-6).

Outro mestre que gostaria de lembrar agora é Frederick Erickson que me ensinou a admirar a etnografia.

[...] O “agora” e "depois" - próximo momento no tempo é o próximo para frente, em relação ao "agora" - provê o conjunto fundamental construindo blocos de construção de interações...

[...] os participantes não somente interferem continuamente com o outro na interação como também complementam reciprocamente a mesma. Isto é, articulam e adaptam mutuamente e reciprocamente o que constitui o "inter" da interação na conversação - [...] ao invés da conversação ser algo simples como uma soma do total de ações separadas por indivíduos distintos (ERICKSON, 2004, p. 4 e 5 - tradução nossa).

Fazer etnografia, portanto, é dar voz a uma minoria silenciosa; é caminhar em um mundo desconhecido; é abrir caminhos passando das contingências para a autodeterminação, para inclusão na escola, na vida social, no mundo da existência solidária e cidadã. Fazer etnografia é um pouco de doação de ciência, de dedicação e de alegria, de vigor e de mania, de estudo e de atenção. Fazer etnografia é perceber o mundo estando presente no mundo do outro, que parece não existir mais. 


\section{Referências}

AGAR, M. Microcomputers as field tools. Computers and the Humanities, vol. 17, p. 19, 1983.

ANDRÉ, M. E. D. A. Etnografia da prática escolar. São Paulo: Papirus, 1995.

ANDRÉ, M. E. D. A. Tendências atuais da pesquisa na escola. Cad. CEDES, Campinas: n. 43, p. 46-57, 1997.

ATKINSON, J. W. Motivation determinants of thematic apperception. In: STEWART, A. (org.), Motivation and society - a volume in honor of David McClelland. São Francisco: Jossey-Bass, 1982.

BOAS, F. Cuestiones Fundamentales de Antropologia Cultural. Buenos Aires: Lautaro, 1943.

BONTE, P. e IZARD, M. Dictionare de l' ethnologie et de l'anthropologie. Paris: PUF, 1991.

BORTONI-RICARDO, S. M.; DETTONI, R. do V. Diversidades linguísticas e desigualdades sociais: aplicando a pedagogia culturalmente sensível. In: COX, M. L P.; ASSIS-PETERSON, A. A. de. (org.). Cenas de sala de aula. Campinas: Mercado de Letras, 2001.

BOURDIEU, P. Distinction: a social critique of the judgment of taste. Cambridge: Harvard University, 1984.

BOURDIEU, P. The production of belief: contribution to an economy of symbolic goods. Media, Culture and Society, p. 261293, 1986.

BOURDIEU, P. O poder simbólico. Rio de Janeiro: Bertrand Brasil, 2004.

DA MATTA, R. O ofício de etnólogo, ou como ter 'Anthropological Blues'. In: NUNES, E. O. (org.). A aventura sociológica. Rio de Janeiro: Zahar, 1978. 
DAUSTER, T. Navegando contra a corrente? O educador, o antropólogo e o relativismo. In: Brandão, Z. (org.). A crise dos paradigmas e a educação. Questões da nossa época. São Paulo: Cortez, 1994.

DAUSTER, T. Um outro olhar: entre Antropologia e Educação. Cad. CEDES, vol.18, n.43, dez., p.38-45, 1997.

DELAMONT, S. Fieldwork in educational settings: methods, pitfalls e perspectives. London: The Falmer Press, 1992.

ERICKSON, F. Audiovisual records as a primary data source. In: GRIMSHAW, A. (org.). Sociological Methods and Research, Special Issue on Sound-Image Records in Social Interaction Research, vol. 11, n. 2, p. 213-232, 1982.

ERICKSON, F. Ethnographic Description in Sociolinguistics. An international handbook of the science of language and society. New York, p. 1081-1095, 1988.

ERICKSON, F. Talk and Social Theory: ecologies of speaking and listening in everyday life. Cambridge: Polity Press, 2004.

ERICKSON, F. Qualitative methods in research on teaching. In: WITTROCK, M.C. (ed.). Handbook of research on teaching. New York: Macmillan, 1986

ERICKSON, F.; SCHULTZ, J. 1977. "When is a Context? Some issues and methods in the analysis of social competence." Quarterly Newsletter of the Institute for Comparative Human Development, vol. 1, n. 2, p. 5-10, 1977.

FREIRE, P. Pedagogia dos sonhos possíveis. São Paulo: Editora UNESP, 2001.

GEERTZ, C. A interpretação das culturas. Rio de Janeiro: Zahar. 1978.

GIDDENS, A. As consequências da modernidade. São Paulo: UNESP, 1991. 
GUSMÃO, N. M. M. de. Antropology and educacion: the origin of a dialogue. Cad. CEDES, vol.18, n.43, p.8-25, 1997.

HAMMERSLEY, M. What's wrong with ethography?

Methodological explorations. London: Routledge, 1992.

MALINOWSKI, B. Argonauts of the Western Pacific. New York: E.P. Dutton; Co. Inc, 1922.

MASON, J. S. Ethnography in cyberspace: data collection via email and instant messaging, ethnographic research. Disponível em: <http://www.stthomasu.ca/inkshed/nlett500/mason.htm>. Acesso em: 12/07/2005.

MATTOS, C.L.G.; CASTRO, P. A. de. Etnografia visual: o uso de imagens na pesquisa etnográfica, II Seminário Interno de Imagem, UERJ. Rio de Janeiro: 2004.

MEAD, M. Growing up in New Guinea: a comparative study of primitive education. London: George Routledge, 1931.

NOVAES, R. R. Um olhar antropológico. In: TEVES, N. (org). Imaginário social e educação. Rio de Janeiro: Gryphus/FE. UFRJ, 1992.

PEIRANO, M. A favor da etnografia. Rio de Janeiro: RelumeDumará, 1995.

PINK, S. Doing visual ethnography: images, media and representation research. London: Sage, 2001.

ROCKWELL, E. Etnografia e teoria na pesquisa educacional. In: EZPELETA, J.; ROCKWELL, E. (org.). Pesquisa participante. São Paulo: Cortez, 1980.

VELHO, G. O Antropólogo pesquisando em sua sociedade: Sobre conhecimento e heresia. In: VELHO, G. (org). O desafio da cidade. Novas perspectivas da Antropologia brasileira. Rio de Janeiro: Gryphus, 1992. 


\title{
A abordagem etnográfica na investigação científica ${ }^{1}$
}

\author{
Carmen Lúcia Guimarães de Mattos
}

Este capítulo explora a etnografia como uma abordagem de investigação científica para demonstrar como esta abordagem de pesquisa traz algumas contribuições importantes ao campo das pesquisas qualitativas, especialmente aquelas que se interessam pelos estudos das desigualdades sociais e dos processos de exclusão.

Introduz o conceito de etnografia e desenvolve aspectos que envolvem o trabalho etnográfico, informando que fazer etnografia implica em: 1) preocupar-se com uma análise holística ou dialética da cultura: 2) introduzir os atores sociais com uma participação ativa e dinâmica e modificadora das estruturas sociais; 3) preocupar-se em revelar as relações e interações significativas de modo a desenvolver a reflexividade sobre a ação de pesquisar, tanto pelo pesquisador quanto pelo pesquisado.

Sinaliza alguns cuidados que podem auxiliar o pesquisador a desenvolver este tipo de pesquisa, em particular preocupações com o período despendido no campo de investigação, a descrição densa e minuciosa dos dados coletados, o processo indutivo de análise, a questão da ética na pesquisa, dentre outros.

1 Texto apresentado originariamente no Curso de Etnografia ministrado pela autora na Faculdade de Educação da Universidade Federal Fluminense em 1990. Foi então publicado parcialmente em 2001 na Revista Espaço INES e posteriormente na Revista Sementes. 
O objetivo deste capítulo é informar pesquisadores que iniciam-se na proposta etnográfica com informações e conteúdos teóricos básicos que considera-se importante para situar este que pretendem utilizar a abordagem para o desenvolvimento de trabalhos científicos em especial na área das ciências humanas e sociais.

\section{Aspectos epistemológicos e conceituais}

A etnografia é um processo guiado preponderantemente pelo senso questionador do etnógrafo. Deste modo, a utilização de técnicas e procedimentos etnográficos, não segue padrões rígidos ou pré-determinados, mas sim, o senso que o etnógrafo desenvolve a partir do trabalho de campo no contexto social da pesquisa. Os instrumentos de coleta e análise utilizados nesta abordagem de pesquisa, muitas vezes, têm que ser formuladas ou recriadas para atender à realidade do trabalho de campo. Assim, na maioria das vezes, o processo de pesquisa etnográfica será determinado explícita ou implicitamente pelas questões propostas pelo pesquisador.

A etnografia como abordagem de investigação científica traz algumas contribuições para o campo das pesquisas qualitativas, em particular para os estudo que se interessam pelas desigualdades sociais, processos de exclusão e situações sóciointeracionais, por alguns motivos entre eles estão: Primeiro, preocupa-se com uma análise holística ou dialética da cultura, isto é, a cultura não é vista como um mero reflexo de forças estruturais da sociedade, mas como um sistema de significados mediadores entre as estruturas sociais e as ações e interações humanas.

Segundo, por introduzir os atores sociais com uma participação ativa e dinâmica no processo modificador das estruturas sociais. Neste sentido, Mehan (1992) afirma que o objeto de pesquisa pode ser o sujeito, sendo considerado como a agência humana no ato de significar as contradições sociais evidenciadas nestas estruturas e processos interacionais. 
Terceiro, por revelar as relações e interações ocorridas no interior das escolas, assim como de outras instituições parte dessas estruturas sociais de forma que esta se abra e evidencie os processos por elas engendrados e de difícil visibilidade para os sujeitos que dela fazem parte (ERICKSON, 1986). Neste sentido, o sujeito da pesquisa, historicamente ator das ações sociais e interacionais, contribui para significar o universo pesquisado exigindo a constante reflexão e reestruturação do processo de questionamento do pesquisador.

Etnografia é também conhecida como: observação participante, pesquisa interpretativa, pesquisa hermenêutica, dentre outras. Compreende o estudo, pela observação direta e por um período de tempo, das formas costumeiras de viver de um grupo particular de pessoas: um grupo de pessoas associadas de alguma maneira, uma unidade social representativa para estudo, seja ela formada por poucos ou muitos elementos, por exemplo: uma escola toda ou um grupo de estudo em uma determinada sala de aula.

A etnografia estuda preponderantemente os padrões mais previsíveis das percepções e comportamento manifestos em sua rotina diária dos sujeitos estudados. Estuda ainda os fatos e eventos menos previsíveis ou manifestados particularmente em determinado contexto interativo entre as pessoas ou grupos.

Em etnografia, holisticamente, observa-se os modos como esses grupos sociais ou pessoas conduzem suas vidas com o objetivo de revelar o significado cotidiano, nos quais as pessoas agem. O objetivo é documentar, monitorar, encontrar o significado da ação.

Tanto a etnografia mais tradicional (GEERTZ, 1989; LÉVISTRAUSS, 1988) quanto a mais moderna (ERIKSON, 1992; WOODS, 1986; MEHAN, 1992; WILLIS, 1977), envolvem longos períodos de observação, um a dois anos, preferencialmente. Este período se faz necessário para que o pesquisador possa entender e validar o significado das ações dos participantes, de forma que este seja o mais representativo possível do significado que as próprias pessoas pesquisadas dariam a mesma ação, evento ou situação interpretada. 
Um dos marcos teóricos que mais se destaca nos estudos etnográficos é o interacionismo simbólico (SCHÜTZ, 1962; PARK; BURGESS, 1921; BLUMER, 1937; THOMAS, 1927), especialmente, aplicados às análises do processo de socialização. Nesta teoria esse processo é entendido como uma negociação constante que não se limita ao vínculo social.

O interacionismo simbólico sintetiza uma das principais escolas de pensamento da sociologia e tem como uma de suas características incorporar a reflexividade na análise da ação (MEAD, 1938). Dentro deste enquadre teórico, buscamos no trabalho de Erickson $(1986,1984)$, dados para explicar o significado da etnografia aplicada à sala de aula e a história intelectual da etnografia, sinalizando o tipo de questões que devemos ter em mente quando usamos esta abordagem de pesquisa.

\section{Etnografia \& Etnologia}

Para entender a abordagem etnográfica na investigação científica se faz necessário distinguir a etnografia de etnologia. Um dos pontos que une essas duas abordagens de pesquisa é o interesse comparativo e a conexão histórica que possuem.

A Etnologia é um termo originário do século XIX para designar estudos comparativos dos modos de vida dos seres humanos. Neste período da história muitos estudos voltaramse para a origem da vida humana: por exemplo, a arqueologia, a linguística histórica, desenvolveu-se na tentativa de revelar a origem da linguagem, a origem do homem.

A Etnologia se origina da composição das palavras etno do grego etnoe, que designa os outros povos que não eram gregos (persas, latinos, egípcios) e da palavra. A palavra grega elenoe designava o povo grego e etnoe todos os outros povos. A parte $\log (0)$ da palavra, significa saber sobre, estudo científico sobre. Portanto, etnologia é o termo para o estudo sistemático ou científico sobre o outro. $\mathrm{O}$ estudo comparativo sistemático da variedade de outros povos diferente do nosso. Etnologia é ramo da antropologia cultural que estuda a cultura dos povos naturais, é o estudo e o conhecimento, sob o aspecto cultural, das populações primitivas. 
A Etnologia emerge como ciência neste contexto, juntamente com a arqueologia, filologia, linguística histórica, paleontologia e a teoria geral da evolução em biologia. Uma das grandes questões do início do século XIX foi o desenvolvimento histórico. Ao mesmo tempo em que a questão da diversidade desse desenvolvimento também emerge neste contexto ainda no mesmo período, os europeus ocidentais estavam engajados no colonialismo em todo o mundo, descobrindo uma variedade imensa de sociedades desconhecidas e radicalmente diferentes nas formas básicas de organização de grupamentos humanos, religião, linguagem. Interesses em estudos comparativos emergiram deste contexto. Portanto, a etnologia apareceu primeiramente em estudos antropológicos ingleses, 50 ou 60 anos antes do aparecimento da etnografia.

A etnografia desenvolve-se no final do século XIX e início do século XX, como uma tentativa de observação mais holística dos modos de vida das pessoas. Foi encontrada primeiramente em livros de viagem, descrevendo sociedades exóticas. Muitos desses livros foram criticados por serem incompletos ou por dramatizarem excessivamente os fatos descritos. Houve também neste período um estudo de caso descrevendo os modos de vida desses povos exóticos, introduzindo desta forma a etnografia que daí se desenvolveu. Um dos marcos históricos na etnografia é o trabalho de Margaret Mead (1928), um trabalho monográfico em pesquisa educacional desenvolvido na universidade de Columbia que tem sido um marco na etnografia até a atualidade. No entanto, a etnologia ficou e ainda permanece como suporte para a etnografia moderna.

Etnografia - Grafia vem do grego graf(o) significa escrever sobre, escrever sobre um tipo particular - um etn(o) ou uma sociedade em particular. Antes de investigadores iniciarem estudos mais sistemáticos sobre uma determinada sociedade ele escreviam todos os tipos de informações sobre os outros povos por eles desconhecidos. Etnografia é a especialidade da antropologia, que tem por fim o estudo e a descrição dos povos, sua língua, raça, religião, e manifestações materiais de suas atividades, é parte ou disciplina integrante da etnologia é a forma de descrição da cultura material de um determinado povo. 
Para Geertz, praticar etnografia não é somente estabelecer relações, selecionar informantes transcrever textos, levantar genealogias, mapear campos, manter um diário " o que define é o tipo de esforço intelectual que ele representa: um risco elaborado para uma "descrição densa" (GEERTZ, 1989, p. 15).

A maior preocupação da etnografia é obter uma descrição densa, a mais completa possível, sobre o que um grupo particular de pessoas faz e o significado das perspectivas imediatas que eles têm do que eles fazem; esta descrição é sempre escrita com a comparação etnológica em mente. O objeto da etnografia é esse conjunto de significantes em termos dos quais os eventos, fatos, ações, e contextos, são produzidos, percebidos e interpretados, e sem os quais não existem como categoria cultural. Esses conjuntos de significantes nos apresentam como estruturas inter-relacionadas, em múltiplos níveis (OGBU, 1981) de interpretação.

Etnografia é a escrita do visível. A descrição etnográfica depende das qualidades de observação, de sensibilidade ao outro, do conhecimento sobre o contexto estudado, da inteligência e da imaginação científica do etnógrafo.

Tradicionalmente, os homens fazem comparações entre sua própria cultura e as de outros povos. Como também, pessoas hierarquicamente mais afluentes observam e comparam as pessoas de menos afluência, sempre observando o outro como diferente de si mesmo. Neste sentido, o que sempre existiu foi uma comparação entre os modos de vida de outros povos que eu estou descrevendo e o meu próprio. Existiu também uma comparação no sentido mais amplo, uma ideia de que o modo de viver comunitário é representativo de um conjunto de opções, por modos de organizações que eram muito mais variados do que as opções oferecidas. Por analogia, este é o modo como pensamos a linguagem como representativa de uma certa escolha na forma de organização social, o que é muito parecido com o que fazemos hoje como etnógrafos. A etnografia sempre teve interesse na comparação etnológica e a maioria das pessoas que faz este trabalho hoje continua a utilizar este instrumento de análise. $\mathrm{O}$ interesse comparativo na 
etnografia é aliado ao interesse na descrição holística da cena, do evento social, e/ou da interação grupal que nos propomos investigar. Ao estudarmos uma sociedade tentamos estudar 0 todo desta sociedade. Ao estudarmos uma vila, observaremos a vila toda - jovens, velhos, área urbana, rural, relações intergeracionais, relações de gênero, de classe - os fatos sociais que ocorrem neste contexto.

Na moderna etnografia, o legado da etnologia é o interesse no desenvolvimento como um todo, dentro de uma dada sociedade, e o interesse em todos os tipos de variações deste desenvolvimento. Uma distinção entre a etnologia e etnografia existe particularmente em estudos de casos comparativos. Em etnografia existe o interesse da sociedade local ou grupo estudado em descobrir e relatar o mais detalhadamente possível todos os tipos de variações que ocorrem dentro deste grupo. Nós não estamos interessados numa forma única de variação em relação ao total da variação humana, mas estamos também interessados em exaustivamente analisar qualquer forma de variação existente no grupo local. Se numa comunidade local existe mais de uma maneira de organização social do grupo, por exemplo, em relação à linguagem, classe social e gênero, nós sempre vamos querer descobrir todos os modos de agrupamento daquele grupo em particular.

\section{Microanálise etnográfica}

A microanálise etnográfica é um instrumento da etnografia, frequentemente utilizada nos estudos da linguagem é caracterizada como: sociolinguística da comunicação, microanálise sociolinguística, sociolinguística interacional, análise de contexto, análise de discurso, análise da conversação. Considerada como micro porque estuda-se particularmente um evento ou parte dele, ao mesmo tempo em que se dá ênfase ao estudo das relações sociais em grupo como um todo, holisticamente (LUTZ,1983). Em microanálise ao mesmo tempo em que se dá ênfase ao significado das formas de envolvimento das pessoas como atores, exige-se do pesquisador um detalhamento criterioso na descrição do comportamento através da transcrição 
linguística verbal e não-verbal de comportamento - olhares, pausas, tom de voz, detalhes da interação e o que isto significa (ERICKSON, 1982, 1992; KENDON, 1977). Na microanálise etnográfica existe uma preocupação com o interesse dos atores sociais na escolha de uma determinada forma de comportamento e qual o significado desta escolha. Portanto, enfatizar-se o significado da interação como um todo, a relação entre a cena imediata da interação social de um grupo e o significado do fato social ocorrido em grandes contextos culturais, por exemplo: cultura da sala de aula, da escola, das escolas em geral. (ERICKSON, 1992).

O etnográfo, utilizando uma teoria crítica de análise aliada à abordagem etnográfica, procura identificar o significado nas relações sociais de classe, etnia, linguagem, gênero, e a cena imediata onde estas relações se manifestam. Por exemplo: numa entrevista de seleção para um trabalho podemos investigar as formas de mobilidade social aplicadas nesse local de trabalho. A microanálise etnográfica leva em consideração não somente a comunicação ou interação imediata da cena, como também a relação entre esta interação e o contexto social maior, a sociedade onde este contexto se insere.

A etnografia, em geral, serve de "background" para a microetnografia. No estudo de caso realizado por Shultz; et.al. (1979) foi analisado o turno de fala, e os padrões culturais da fala, comparando culturalmente um grupo familiar de origem italiana com uma família americana. Neste caso após extensivo trabalho de observação participante, alguns segmentos de fala foram destacados para microanálise. Exemplo disso está em um outro trabalho etnográfico (MATTOS, 1992) baseado nas percepções sobre o fracasso escolar entre três grupos: 1 ) jovens multirepentes e excluídos; 2) pais, professores e diretores de escola; 3) políticos e administradores do sistema educacional. A pesquisadora realizou um estudo microanalítico de uma sala de aula para ilustrar como as relações intra-escolares, especialmente a relação professor-aluno, destacando como podem contribuir para o entendimento sobre os processos de exclusão escolar nas séries iniciais do Ensino Fundamental. 
Na microanálise etnográfica, quando estudamos a sala de aula, observamos por um longo período de tempo, uma escola, uma sala de aula, um professor. Para depois particularizaremos um processo interacional ou um fato que consideramos microanaliticamente relevante. Isto é, destacamos um fato que numa micro-dimensão pode representar o todo do processo estudado. No estudo de Shultz et. al., (1979), cinco pesquisadores observaram por dois anos, um professor e 27 alunos, visitando as famílias, gravando as aulas, observando as situação da escola, a comunidade local, a situação da comunidade no contexto geográfico e político, a situação cultural do grupo e as relações entre esta comunidade ou esse grupo em contraste ou semelhança com outras comunidades ou outros grupos, observando os detalhes nas formas de fala. Do mesmo modo Mattos (1992), em seu trabalho de pesquisa, observou durante dois anos duas comunidades, uma na favela e outra na zona rural, visitas sistemáticas foram realizadas em classes com dificuldades de aprendizagem. Duas destas classes foram selecionadas para um estudo mais detalhado de oito meses, o que culminou com um estudo de caso de uma delas, descrito através de uma microanálise, onde detalhes da interação entre professora e alunos tornaram-se parte significativa do contexto da sala de aula e do tipo de interação existente. Após este intensivo trabalho de observação, o desafio do etnógrafo é tentar organizar todos os dados como num quebra-cabeça. Partindo do contexto maior olhando a comunidade como um todo até poder destacar uma particularidade de possível generalização ou que melhor ilustra o contexto estudado de modo que possa ser microanaliticamente relevante.

\section{Significado e sua significação}

O significado local e a organização do significado local para a pessoa estudada constituem, assim como a comparação e a descrição densa, aspectos importantes a serem observados no trabalho etnográfico. Pressupomos que no "pequeno mundo" de uma sala de pré-escolar exista uma ordem particular de organização sociocultural, por ser conduzida por um tipo particular de professor, sua filosofia de trabalho, sua origem 
sociocultural, a classe social em que a comunidade está inserida, e ainda por causa da personalidade individual das pessoas envolvidas. Quando existe um grupo de pessoas reunidas para se socializar, uma ordem social é desenvolvida para aquele grupo particular de indivíduos (HYMES, 1977; GOFFMAN, 1981). Isto acontece nas escolas, nas fábricas, nos hospitais, nos escritórios, onde quer que as pessoas se encontrem regularmente para socializar de alguma forma. Existe uma ética de organização e um significado que é peculiar a este grupo especificamente.

A etnografia está interessada no significado local para estas pessoas em particular. Existe este interesse geral em comparação com todos os outros modos de ser e fazer que nós conhecemos como humanos, mas existe também o interesse no estudo de caso local, de ser bem específico sobre o significado da organização de um grupo particular de pessoas. Como na linguística, estamos interessados em alguma coisa que é universal sobre a linguagem enquanto ela mesma, na forma que a conhecemos, mas só podemos aprender sobre a universalidade estudando os casos particulares. Só entendemos a variação gramatical ou fonética das várias línguas, olhando uma língua de cada vez. Em cada língua em particular nós estamos vendo um universo particular, um universal concreto (ERICKSON, 1986). Todo indivíduo fala sua própria língua e dialeto particular; então existe sempre uma forma de falar que é particular a um indivíduo e neste aspecto ele é um universo concreto de estudo da língua.

O interesse no local e no particular está inerentemente conectado com o interesse no geral e universal. Por exemplo, existe alguma coisa sobre o desenvolvimento das crianças que Piaget aprendeu estudando os seus três filhos, que são comuns a todas as crianças, mas precisamos de muito tempo e estudos para nós descobrirmos que nem todas as crianças desenvolvem-se exatamente como as três crianças de Piaget. Então alguma coisa sobre estas três crianças era universal concreto em desenvolvimento, mas outras coisas eram muito específicas a este tipo de crianças oriundas da classe alta, filhas de um intelectual suíço num momento histórico particular. 


\section{Abrangência da Etnografia e suas finalidades}

Os estudos sociolinguísticos preocupam-se com as variações linguísticas e procuraram dentro de uma dada sociedade ou comunidade, por todos os tipos de variações nos modos de falar ou uso da fala (HYMES, 1977). Isto é, quando uma pessoa usa a língua para ser cortês, para persuadir, não iremos procurar um tipo de persuasão ou um tipo de tratamento cortês, queremos observar todos os tipos de tratamento existentes. Todos os modos de humor que uma pessoa manifesta numa dada situação de interação, como também todos os tipos de agrupamentos ou todas as relações de subordinação e insubordinação manifestas em um evento particular ou em uma dada ação neste evento. Queremos saber se numa sala de aula a relação de subordinação e insubordinação entre a professora e os alunos é a mesma para todos os alunos ou se existem alguns alunos que desfrutam de privilégios mais que outros em sua relação com a professora. Entre os alunos, pesquisamos, se é diferente o caráter da relação de subordinação e insubordinação entre eles, se existem variações entre o caso de uma sala de aula específica comparando-se com outras salas de aulas. Queremos investigar as relações entre ricos e pobres, oprimidos e opressores, grandes e pequenos, meninas e meninos, procuramos investigar se diferença em subordinação ou de poder é uma preocupação específica de um grupo em particular. Queremos observar todas as identidades sociais existentes: gênero, idade, classe social, riqueza, entre outras.

A questão básica na pesquisa etnográfica é delinear a abrangência das variações: Qual é a abrangência das variações de "X" ou de "Y”? Se estivermos analisando a família, vamos querer saber quantos irmãos menores existem, não que o nosso interesse esteja somente no tipo de agrupamento por faixa etária, mas também se um dos irmãos menores tem mais privilégios que o outro, se tem, porquê e como este dado é percebido na abrangência geral da organização familiar como um todo. Se estivermos analisando a sala se aula de leitura, quantos tipos de reações a uma aula de leitura têm uma professora? Ela reage do mesmo modo para um tipo de leitura de um 
aluno que para outro tipo? Alguns erros contam para ela mais que os outros? Em que circunstâncias isto ocorre? Quando um mesmo erro é relevante numa interação e irrelevante em outra? São os alunos diferentes quando esta discrepância de reação ocorre? São eles pobres ou ricos, meninas ou meninos, fracos ou fortes? Eles pertencem a uma mesma classe social? Estamos sempre procurando a totalidade de variações manifestas numa ação, fato, fenômeno, ou situação na qual estamos interessados.

\section{Perspectiva dialética}

A perspectiva dialética, assim como a comparação, a densidade descritiva, o significado e sua organização e as variações, consiste numa preocupação da etnografia. Dialética no sentido fundamental da noção, que os norte-americanos chamam, de relação ecológica entre os vários atores sociais ou grupos numa comunidade ou instituição, movimento histórico vivenciado pelos atores sociais num determinado espaço de tempo. Procuramos as relações entre estes fenômenos e não apenas um fenômeno particular. Queremos observar o significado de um erro específico de leitura para uma criança, comparandose este erro com o de outra criança na mesma situação de leitura, querendo saber se existem privilégios entre as duas. Queremos saber como agem as meninas em relação aos meninos. São os modos de agir delas iguais ou diferentes aos dos meninos? Não estudamos somente as meninas ou os meninos, estudamos também as relações entre eles. Nós não estudamos a escrita isoladamente, nós queremos entender como a habilidade em escrever um ensaio literário desenvolvido por uma certa pessoa, pode influenciar a habilidade que esta mesma pessoa pode desenvolver escrevendo um ensaio científico, ou como estas habilidades relacionam-se entre si e em relação às habilidades de outras pessoas nestas mesmas tarefas. 


\section{Quantitativo versus Qualitativo}

Um trabalho quantitativo em educação assim como em outros campos de estudo, muitas vezes, considera o fenômeno isolado em si mesmo e isto pode torna-se problemático; o problema é o uso da quantificação, de um sumário numérico para expressar um fenômeno em sua totalidade, tratando-o de maneira abstrata.

Gostaríamos de tentar entender algumas questões quanto a esta abordagem. Existe uma sofisticada matemática que pode ajudar quanto a isso. No entanto, é a ação operacional de pinçar um item isolado do fenômeno ou contexto e tratá-lo isoladamente da sua totalidade, das relações maiores que este contexto apresenta que se apresenta como um complicador desta abordagem. Tratar o fenômeno diferente do contexto maior a que ele pertence, sem olha-lo ecológica ou dialeticamente, sem olhar o todo e as partes ao mesmo tempo pode fazer com que se perca 0 sentido do todo do fenômeno a ser compreendido.

Nesta abordagem, frequências são tabuladas e comparadas com outro grupo que frequências pinçadas de um outro contexto e podemos perder o sentido de relação entre estes dados ou itens que pinçamos. Este não é um privilégio somente da estatística, mas sim uma questão de utilização de um dado fora de contexto; nós podemos fazer isto sem estatística.

A maioria das falsas argumentações entre quantificação e pesquisa qualitativa está relacionada ao mapeamento das questões fundamentais a que nos propomos a entender, estudar ou pesquisar. Para alguns tipos de pesquisa temos que ter uma percepção dialética ou ecológica, não podemos usar certos tipos de quantificações. De forma isolada. Não que contar as coisas seja um erro, mas porque inerentemente ao ato de quantificar, temos que abstrair um item para contá-lo e as pessoas que fazem quantificação podem estar equivocadas em enfatizarem fenômenos considerados destacados em relação a outros fenômenos.

Não precisamos somente quantificar para intelectualmente fazer ciência. Ocasionalmente crucificamos, por algumas razões, pesquisas estatísticas em educação ou em outros campos, 
as linhas de trabalho do gênero experimental ou estatística, não podemos penalizar a estatística ou as experimentações ou achar que somente estas linhas de trabalho são responsáveis por alguns tipos de problemas nas pesquisas sociais, porque esta não é a realidade.

É importante relembrar que o interesse da etnografia reside no estudo das variações de determinado caso e das relações entre estas variações e as variações próprias do contexto maior em que este caso está inserido. Temos também uma preocupação específica com uma perspectiva dialética ou ecológica na pesquisa social que se contrapõe à abordagem quantitativa no sentido do tratamento que esta linha dá ao caso estudado. $\mathrm{Na}$ abordagem dialética temos interesse na totalidade do problema e não simplesmente no tratamento isolado de uma parte do mesmo. Entretanto, isto não significa que abandonemos a estatística como método de tratamento de dados; ao contrário a quantificação utilizada de maneira sensível será de grande valia para a análise etnográfica.

\section{Interação - Contexto - Interação}

Antes de trabalharmos a utilidade desses conceitos na prática da pesquisa etnográfica, se faz necessário explicar a natureza dos termos que estamos aplicando. Interação é o processo que ocorre quando pessoas agem em relação recíproca, em um contexto social. Este conceito implica numa distinção entre ação e comportamento. Comportamento inclui tudo que o indivíduo faz. Ação é um comportamento intencional baseado na ideia de como outras pessoas o interpretarão e a ele reagirão. Na interação social, percebemos outras pessoas e situações sociais e, baseando-nos nelas, elaboramos ideias sobre o que é esperado, e os valores, crenças e atitudes que a ela se aplicam. Nessa base, resolvemos agir de maneira que terão os significados que queremos transmitir (MEAD, 1938; SCHÜTZ, 1932; WEBER, 1921; WOODS, 1992).

Ao pesquisarmos a organização dos processos de interação é interessante estudarmos como as pessoas em interação formam ambiente um para o outro (KENDON, 1977), até mesmo 
além do limite desta interação imediata, onde sempre existe o interesse nas relações ambientais. Por exemplo, o que significa para as meninas conviverem com meninos em sala de aula? Como as diferenças sócio-culturais-econômicas se manifestam na sala de aula? O que isso significa? Como isto acontece? Como o modo de agir de um grupo ou uma pessoa influencia outro grupo ou outra pessoa? Essas são algumas das questões que estamos interessados quando na investigação sobre a interação na sala de aula.

Concordamos com Geertz, quando explica que o conceito de cultura é semiótico, como tal, não é um poder, alguma coisa que pode ser atribuída casualmente - aos fatos sociais, aos comportamentos, as instituições ou aos processos, cultura é contexto, onde esses fatos, comportamentos, instituições, etc., podem ser descritos de forma inteligível, com densidade (GEERTZ, 1989). Considerar cultura como contexto, implica em ampliar nosso entendimento sobre contexto, como simplesmente um local, o background de uma cena, aquilo que é parte integrante do fato, do evento, significa estudar também o que entendemos por cultura. Cultura é forma como o homem significa o seu mundo a partir da teia de signos e símbolos que ele criou e teceu ao longo de sua história (WEBER, 1921; GEERTZ, 1989; ERICKSON, 1987).

$\mathrm{Na}$ abordagem dialética da análise de um contexto devemos evitar o estudo de um fragmento da fala isolado, destacado do que esta significa para pessoa que falou e para as outras pessoas dentro do contexto. Devemos observar em detalhe a ação verbal e não-verbal na cena em que ocorre a interação e o evento de fala (KENDON, 1977). A preocupação é com a totalidade. Como a totalidade influência às partes desta totalidade em si mesma e em cada outra parte do todo.

Interação é movimento, porque existe uma nova atividade acontecendo a cada momento, existe um novo momento da história ocorrendo a cada movimento social cotidiano. O contexto existe e isso é importante de ser determinado, mas é importante ainda saber a recorrência deste contexto em relação ao objeto de estudo. Saber quando um contexto aparecerá novamente, seu padrão de recorrência, é parte fundamental da 
aprendizagem da análise sociocultural. A questão que envolve a identificação de um contexto já foi explorada em alguns estudos interpretativos e envolve um tipo característico de problema apresentado em pesquisas etnográficas - como uma pessoa pode usar apropriadamente uma forma de interação social que se torna imprópria em outro contexto. Esta impossibilidade de contextualizar um dado de pesquisa dificulta para o pesquisador entender o significado da interação para o seu estudo (SHULTZ; et.al.,1983). Estamos nos reportando ao entendimento da ecologia ou dialética de organização de uma cena interativa, como a interação muda de momento para momento, de contexto para contexto é vista como um sistema flutuante, não fixo, portanto, difícil de significar.

\section{A ironia da abordagem etnográfica}

A ironia neste projeto intelectual que é a etnografia é que o que o etnógrafo tenta fazer continuamente é falar sobre organização da interação no contexto de modo que esta fala seja significativa para os atores sociais que estamos investigando. Como nos diria Paulo Freire, falar com ele e não sobre eles, e isso é uma tarefa muito difícil, se não, quase impossível.

$\mathrm{Na}$ tentativa de significar o local pela narrativa descritiva usando termos que são o mais próximos possíveis daqueles usados pelos atores sociais que participam deste projeto, termos que eles usariam se lhes fossem permitido falar. Fazer isso é diferente de escrever "protocolos" de fala onde se desenvolve uma interação com grande detalhe do comportamento do que as pessoas fazem. Estes podem ser acurados, mas o que os torna etnográficos são as descrições feitas usando os termos mais próximos dos problemas e significados numa perspectiva das pessoas mesmas. Ao escrevermos uma narrativa, temos que colocar os atores como eles se apresentam sob a perspectiva deles. Para isso é importante se conhecer o significado local da ação. Ao tentarmos escrever sobre o outro, o ethnoe, de uma maneira em que o ponto de vista dele seja considerado, estamos tocando num ponto frágil da utilização da abordagem etnográfica: a tentativa de fazer sentido, das maneiras de organização 
dos outros de um modo que não seja comprometedor, não seja invasor, não seja discriminatório, não seja opressor, ou não seja excludente.

A irônica dificuldade deste trabalho é que, a priori, nunca conseguiremos dar conta desta tarefa - descrever o outro sob o ponto de vista dele mesmo. Na melhor das intenções, utilizando instrumentos como o vídeo, podemos chegar mais perto da ação que está realmente acontecendo, mas isso não é suficiente. Portanto, genericamente é frustrante e insatisfatório o trabalho de pesquisa etnográfica. Essa ironia deve motivar a meditação para os pesquisadores, mas é o reconhecimento deste dilema que nos impulsiona na tentativa de sua superação. O reconhecimento desta limitação não deve porém nos imobilizar ou criticar radicalmente. Este tipo de abordagem, ao contrário, reconhece os pontos frágeis de um paradigma científico de investigação indicando quando podemos melhor utilizá-la em nossas pesquisas.

\section{Ênfase na questão de pesquisa}

O trabalho etnográfico tem mais interesse na proposta da pesquisa do que no procedimento de coleta de dados. Um instrumento de pesquisa não constitui necessariamente um método de pesquisa. Portanto, devemos enfatizar os problemas de conteúdo da pesquisa, do tema a que nos propomos pesquisar, tanto quanto ou mais que, nos procedimento utilizado por ela. Em etnografia o trabalho de investigação precisa ser visualizado em sua totalidade, com propósitos bem definidos.

A concepção teórica que define um fenômeno primário de interesse no estudo etnográfico sobre o processo de ensinar, por exemplo, é muito diferente dos interesses que orientavam os estudos sobre este processo tradicionalmente. Não queremos com isso fomentar a competição entre os diversos paradigmas que orientam a pesquisa educacional historicamente, ao contrário a convivência harmônica de todos os modos de fazer pesquisa, algumas vezes até a superposição 
de modelos, demonstra que a esta convivência é necessária e, até desejável. Os velhos paradigmas não morrem, na melhor das hipóteses, podem ser superados pelos novos, incorporando-os.

Em etnografia tentaremos combinar uma análise detalhada de comportamentos, seus significados no dia-a-dia de interação social. Analisaremos também o contexto social maior em que este comportamento está inserido. A análise da interação face a face é uma das formas de procedimento que podemos escolher para realizar esta tarefa. Queremos ser específicos sem sermos abstratos, sermos empíricos sem sermos positivistas, sermos rigorosos, sem sermos obsessivos (ERICKSON, 1988).

\section{O trabalho etnográfico}

Sem a pretensão de estar especificando procedimento de investigação etnográfica, mas consciente de que a prática envolve muito fazeres dos quais pesquisados mais inexperientes não estão muito atentos.

O trabalho de campo envolve métodos e procedimentos nos quais temos que ser radicalmente indutivos para a seleção do que deve ser importante para a pesquisa. As categorias ou temas que escolhemos para observar não são necessariamente escolhidos previamente; na maioria das vezes esta escolha se dá a partir do desenvolvimento do trabalho de campo, a esse movimento da pesquisa chamamos hipóteses progressivas (HAMMERSLEY, 1983), pois a cada momento de reflexividade sobre o trabalho de desempenho no trabalho, modifica-se o caminhar e cria-se um movimento próprio aos dados e como de eles refletem as nossas questões. Indução e dedução estão constantemente em diálogo com este procedimento analítico. $\mathrm{O}$ pesquisador delineia sua linha de questionamento os temas que passam a pertencer ao corpo do trabalho. Estes temas podem mudar em resposta ao caráter distinto de um evento ocorrido no local da pesquisa. Por isso, quando realizamos um trabalho etnográfico temos que ter em mente as seguintes questões: 1) o que está acontecendo, especificamente, numa 
ação social que ocorre num lugar ou situação particular?; 2) o que estas ações significam para os atores envolvidos nelas, no momento em que estas ações aconteceram?; 3) como os acontecimentos são organizados dentro dos padrões sociais de organização e dos princípios culturais aprendidos para a conduta no dia-a-dia?; 4) são as pessoas envolvidas no local onde a ação ocorreu consistentemente presentes uns para os outros constituindo ambiente significativo um para o outro?; 5) como o que está acontecendo num lugar, sala de aula (como um todo) se relaciona com acontecimentos ocorridos em outros níveis do sistema, fora ou dentro deste local (escola, família da criança, o sistema escolar, federal, estadual)? e, 6) como as ações rotineiras da vida num local determinado é organizado comparado com outras ações ou modos de organização social de vida numa abrangência maior de lugares no tempo e no espaço?.

$\mathrm{Na}$ pesquisa educacional, respostas para perguntas como estas devem ser consideradas pela seguintes razões: 1) a invisibilidade da rotina diária (“tornar” o que nos é familiar, estranho); 2) a necessidade de entender e documentar detalhadamente a prática social concreta dos atores; 3) a necessidade de estudar o significado local dos acontecimentos para os atores; 4) a necessidade de um entendimento comparativo de diferentes locais onde ocorrem ações sociais e, 5) a necessidade do entendimento comparativo que vai além da compreensão imediata das circunstâncias locais da ação.

\section{Considerações finais}

Na pesquisa etnográfica a especificidade das ações, as perspectivas e significado dos atores sociais são consideradas. $\mathrm{O}$ grupo de maior incidência de interesse como participantes nesta abordagem de pesquisa, são como já consideramos, pessoas diferentes, portanto, passíveis de serem desprezadas em outras abordagens de pesquisa por não constituírem um padrão determinado e validável para generalizações para o todo da sociedade. Possuidores de reduzido poder de participação como membros ativos de uma sociedade - meninos de rua, presidiários, negros, mulheres, professores, estudantes, trabalhadores, 
pacientes de hospitais e hospícios - perfilam entre os participantes mais comuns em pesquisas etnográficas.

Os significados e as perspectivas que buscamos em etnografia, são, muitas vezes, inconscientes para as pessoas que os possuem. Estas são, às vezes, pouco articuladas para explicitar concretamente sua compreensão sobre como vivem e porque agem desta ou daquela forma. A significação dada a sua rotina por esses atores sociais são vistos, algumas vezes, pelo pesquisador, como secundários ao objetivo central da pesquisa, ou irrelevante, teoricamente. Por exemplo, em organizações governamentais as quais os municípios são de certo modo subordinados, expressões como nós já sabemos o que os municípios querem podem ser comumente ouvidas, mesmos que as pessoas dos municípios em questão, sequer tenham sido ouvidas.

Em etnografia de sala de aula, nota-se que é uma exceção, a influência positiva do professor para o sucesso das crianças em risco de fracasso escolar (MATTOS, 1992). O risco do fracasso parece referir-se sempre ao ambiente social ou ao passado familiar da criança. Este risco não se refere à habilidade intuitiva da criança. Sob a perspectiva etnográfica não faz sentido falar sobre esta habilidade intrínseca, de modo isolado, uma vez que a criança sempre se encontra num ambiente social, assim como o desempenho dessa criança. Podemos dizer que o perfil das habilidades da criança a que o pesquisador tem acesso é construído socialmente tanto pelo pesquisador quanto pela criança.

Talvez a mais básica diferença entre a linha etnográfica de pesquisas e as outras pesquisas qualitativas de sala de aula é que estas procuram pela natureza causal do fenômeno, ao passo que a etnografia busca a natureza processual, as formas como as relações são construídas numa sala de aula em particular ou nas interações interpessoais desenvolvidas no âmbito escolar e social. 


\section{Nota}

Para melhor exemplificar os procedimentos que envolvem o trabalho etnográfico, apresentamos em anexo tarefas que foram adaptadas do trabalho de Erickson (1988). Estas tarefas ao serem realizadas possibilitam uma imersão da pessoa que as realiza no trabalho de investigação dentro da abordagem etnográfica e algumas das etapas pertencentes a ele. Esperamos que estes exemplos de exercícios etnográficos venham ajudar, particularmente, alunos e professores que estudam os modos de investigação e seu fazeres. 


\section{Referências}

BLUMER, H. Symbolic Interacionism: perspective and method. Chicago: University of Chicago Press, 1937.

BURNS, A. F. Doing the ethnography of schooling: educational anthropology in action. Anthropology \& Education Quarterly, v. 14, p. 288-291, 1983.

ERICKSON, F.; SHULTZ, J. When is a context? Some issue ans methods in the analysis of social competence. In: GREEN, J. L.; VALLAT, C. (org.). Ethnography and languague. Norwood, NJ: Ablex Press. 1981.

ERICKSON, F. Money tree, lasagna bush, salt and pepper: social construction of topical cohesion in a conversation among italianamericans. In: TANNEN, D. Analyzing discourse: text and talk. Washington, DC: Georgetown University Press, 1982.

ERICKSON, F. Qualitative methods in research on teaching. In: WITTRICK, M. C.(org.). Handbook of research on teaching. New York: Macmillan, 1986.

. Conceptions of school culture: an overview. Educational Administration Quarterly, v. 23, nº. 4, Nov. p.11-24, 1987.

. Ethnographic decription. In: AMMON, U., DITTMAR, N.; MATHIER, K. (ed.) An international handbook of the science of language and society. v. 2. New York: Walter de Gruyter, 1988. p. 1081-1095.

. Ethnographic microanalysis of interaction. LECOMPTE, M. D., MILLROY, W. L.; PREISSLE, J. (Ed.). The Handbook of Qualitative Research in Education. New York: Academic Press, 1992. p. 201-226.

ERICKSON, F.; MOHATT, G. Cultural organization of participation structures in two classrooms of indian students. In: SPINDLER, G. (org.). Doing the ethnography of schooling. New York: Holt, Rinehart \&Winston, 1982. 
ERICKSON, F. What makes school ethnography 'ethnographic'? Anthropology Educational Quarterly, v.15, p. 51-66, 1984.

GEERTZ, C. A interpretação das culturas. LTC: Rio de Janeiro, 1989.

GIDDENS, A. Política, Sociologia e Teoria Social. São Paulo: UNESP, 1997.

GOFFMAN, E. Forms of talk. Philadelphia: University of Pennsylvania Press, 1982.

MATTOS, C. L G. Picturing school failure: a study of diversity in explanations of educational difficulties of difficulties among rural and urban youth in Brazil. 1992. 268f. Thesis. (Ph. D. in Education) - Graduate School of Education, The University of Pennsylvania, Philadelphia. USA, 1992.

HAMMERSLEY, M.; ATKINSOM, P. Ethnography: principles in practice. London: Tavistock, 1983.

HYMES, D. Qualitative/Quantitative research methodologies: a linguistic perspective. Anthropology \& Education Quarterly, v. 8, p. 165-176, 1977.

KENDON, A. Studies in behavior of social interaction. Bloomington: University of Indiana Press, 1977.

LÉVI-STRAUSS, C. Tristes trópicos. Barcelona: Paidós, 1988.

LUTZ, E. W. Ethnography: the holistic approach to understanding schooling. In: GREEN, J. D.; WALLET, C. (Ed.). Ethnography and language in educational setting. Norwood, NW: ABLEX, 1981.

MEAD, G. H. The Philosophy of the act. Chicago: University of Chicago Press, 1938.

MEHAN, H. Understanding inequality in schools: the contribution of interpretative studies. Sociology of Education, v. 62, $\mathrm{n}^{\mathrm{o}} 1$, p. 265-286, 1992. 
OGBU, J. U. School ethnography: a multilevel approach.

Anthopology and Education Quarterly, vol. 12, n. 1, p. 3-29, 1981.

PARK, R. E.; BURGESS, E. W. Introduction to the Sciences of Sociology. Chicago: University of Chicago Press, 1921.

SCHÜTZ, A.; et. ali. Collected papers 1. The problem of social reality (Phaenomenologica). The Hague: Martinus Nijhoff, 1962.

SCHÜTZ, A. The Phenomenology of the social world. Londres: Heinemann, 1979.

SHULTZ, J.; FLORIO, S.; ERICKSON, F. Where's the floor? In: GILMORE, P.; GLATTHORN, A. A. Etnography and Education: children in and out of school. Washington: CAL Press, 1979.

THOMAS, W. I.; ZNANIECKI, F. The polish peasant in europe and America: monograph of an immigrant group. v. 1. Primarygroup organization. Boston: R. G. Badger, 1918.

WEBER, M. Economy and Society. New York: Bedminster Press, 1921.

WILLIS, P. Learning to labor: working class kids get working class jobs. Farnborough, Eng: Saxon House, 1977.

WOODS, P. Inside schools. Ethnography in educational research. London: Routledge, 1986.

WOODS, P. Symbolic interactionism: theory and method. LECOMPTE, M.D.; GOETZ, J.P. (org.). The handbook of qualitatative research in education. London: Academic Press, 1992. 


\section{Tarefa 1 Tornar o familiar estranho}

Auto-observação sobre sua capacidade de observação.

Você tentará observar as diversas situações com as quais se envolve durante o dia. Sociolingüísticamente o problema é sabermos como nós mudamos estilos e estratégias sem percebermos.

Adquira um conjunto de cartões do tipo abaixo representado -você pode precisar de 50 fichas ou mais ou utilize recursos digitais disponíveis em diferentes gadgets do tipo celulares, Ipods, Ipads ou similares
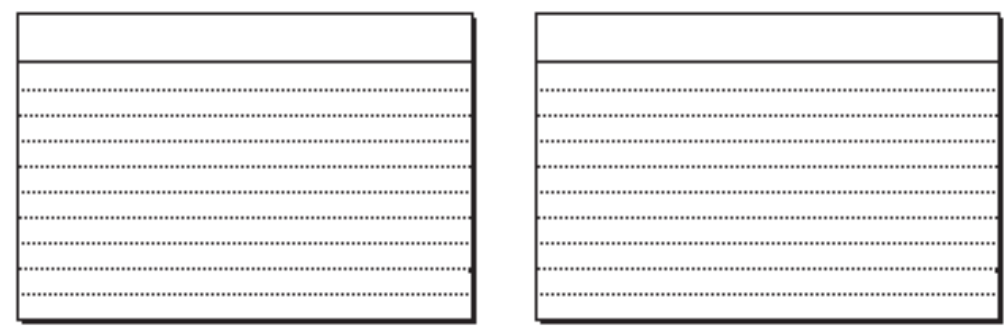

Nestas fichas escreva comentários sobre todos os momento em que você tiver a sensação de ter mudado de cena durante 0 dia - situação de interação com pessoas, animais, objetos, etc.

Pense que você está sendo filmado e lembre-se como uma outra pessoa registraria este evento do seu dia a dia.

Registre nas fichas todas as vezes que a cena mudar. Escreva o mais detalhadamente possível a cena, o lugar e tudo que lembrar. A seguir registre qual foi o sentimento que envolveu a cena, tente ser objetivo, claro e sensível ao contexto em que ocorreu a cena. 


\section{Tarefa 2 Evidenciando diferenças}

Entrevista etnográfica - primeiros passos

Escolha uma pessoa que você considere diferente de você, partindo do princípio de que todos somos diferentes. Escolha aquela que se opõe a você no discurso, no comportamento, nos valores, dentre outras, de modo a estabelecer algum parâmetro comparativo entre você e esta pessoa. Está pessoa será seu entrevistado.

Eleja um tema que possa ser de interesse mútuo e declare seu objetivo para o seu entrevistado ao mesmo tempo buscando em você um alinhamento lógico para conduzir a entrevista, de modo que o tema coberto durante a condução das perguntas da entrevista.

Num processo de perguntas aberta você tentará saber o que o entrevistado pensa sobre o cotidiano dela ou dele, como é esta rotina e o que os eventos desta rotina significam para ele ou ela.

Pergunte: O que você faz ao acordar? Onde costuma ir ? Quando retorna de suas saídas diárias? Se, ele/ela, sente-se confortável com esta rotina? O que acontece para que sinta-se desconfortável ou confortável com o seu dia a dia.

Para investigar sobre a natureza do cotidiano do entrevistado e tentar significa-lo, faça as perguntas de modo a evitar que o entrevistado se exponha de modo embaraçoso. Pergunte a você mesmo como se sente com estas perguntas.

Peça que ao entrevista que fale em poucas palavras, por exemplo: Como você sabe que está interessado em alguma coisa? Como você demonstra que concorda ou discorda de um assunto? Como um colega seu faria isto? Em seu trabalho, escola, família, bairro, reuniões que frequenta, o que as pessoas fazem para demonstrar que o que estão falando naquele momento é o mais importante sobre o que elas tem a dizer ? Para mostrar que estão concluindo o que estão falando. Para demonstrar que você pode confiar nele e que você pode acreditar no que elas estão falando. Como você faz para causar uma 
boa impressão nos outros? Como você demonstra atenção e educação no trato com os outros?

Como observador e entrevistador, pergunte a você mesmo todas as questões de modo a antecipar algumas reações. Se você sentiu-se confortável com as perguntas vá em frente, pergunte!

Observe as expressões do entrevistado, o que faz com o corpo, com os olhos. Se possível utilize o registro de vídeo direcionando a câmera para o entrevistado, além do registro em áudio. 


\section{Tarefa 3 Qual é o ponto específico da análise?}

O processo de análise de dados

Revise suas notas de campo, registros, documentos coletados e outros, identificando um padrão em seus dados.

Formule uma afirmação baseada no padrão que você encontrou.

Retorne aos dados e identifique um evento típico que ilustre a afirmação que você fez. Esta instância - citação, caso, fato, ocorrência , vai prover evidências de que o que você está afirmando está realmente acontecendo, pelo menos uma vez, e de preferência será uma cena ou fato cuja frequência ocorra com regularidade num determinado evento.

Escreva sua afirmativa em forma de vinheta narrativa - que não deve ser maior que duas páginas e meia. Nesta vinheta apresente algumas sentenças para identificar o local onde o evento se deu, seja o mais concreto, vivido e preciso que você puder quando descrever a sequência do evento. Apresente detalhes específicos de comportamentos verbais e não-verbais, citações diretas de fala, e descreva o local físico. Dentre diferentes unidades que compõem a ação na sequência como um todo, varie o nível descritivo de detalhes. Use variações - nos detalhes que deixou de fora, e especialmente nos detalhes que você incluiu para chamar a atenção e deixar claro para o leitor que o evento que você descreveu é consistente e valida a afirmação que você fez. No final da vinheta, reitere a sua afirmação e complementea com alguns comentários interpretativos, contando ao leitor o ponto chave da vinheta. Complemente, se possível, com teorias e outros casos analisados em outras pesquisas.

Agora faça outra afirmação sobre o mesmo evento que você descreveu na primeira vinheta. Esta deve ser também uma afirmação sobre outro padrão recorrente encontrado em seus dados. No entanto, a segunda afirmação deve ser diferente da primeira - isto é, se sua primeira afirmação foi sobre um padrão de percepção do professor, por exemplo, faça a segunda sobre um padrão de percepção do aluno. 
Escreva sua segunda afirmação. Siga os mesmos passos que seguiu para a primeira vinheta narrativa. Mude o tipo de detalhes que você deixou de fora, e mude o nível de detalhes ao longo de uma unidade constitutiva da ação em toda a sequência dos eventos. De modo que a vinheta reescrita agora, ilustre sua segunda afirmação melhor que ilustra a primeira. Outra vez, siga a vinheta e reitere sua segunda afirmação com pontos substantivos que a ilustrem, adicionando algumas sentenças com comentários interpretativos, incorporando teorias conhecidas ou novas que pretende formular com os seus dados. 


\section{Tarefa 4 Espere até que você ouça isto!}

Os dados da pesquisa falam com você

Revise seus dados de entrevista, de vídeos, de documentos, etc., para identificar um padrão em seus dados diferente daqueles que foram utilizados no exercício anterior.

Faça uma afirmação baseada no padrão que você identificou.

Volte aos seus dados procure pelo que as pessoas falaram no local - tanto dados de entrevistas quanto dados das notas de campo ou outros similares. Escolha uma citação de pelo menos uma sentença - quando de entrevistas, é preferível duas ou três sentenças - que ilustre e garanta sua afirmação.

Escreva sua afirmação. Siga a exata transcrição - se fizer uso de áudio-teipe da citação. Não use paráfrase daquilo que a pessoa falou, deixe com a exata fonologia, palavra escolhida, e gramática que a pessoa usou. Se o tom de voz, o tempo, ou o volume forem importantes e significativos tente mostrar isso na forma que você apresenta a citação. Acompanhe a citação com dois conjuntos de sentenças contendo comentários interpretativos, no qual você explica ao leitor o que você acha que está pessoa disse-qual o significado que as palavras desta pessoa tem para ela, no seu entendimento. No primeiro comentário interpretativo - que não deverá ser mais que um parágrafo, explique o significado da citação com base no formato e no conteúdo da citação mesma (isto é, palavras escolhidas, tom de voz, etc.). No segundo comentário interpretativo - lembre-se, que deve ser o mais breve possível - acrescente quantas informações contextuais achar necessário para a fazer uma triangulação, das informações das notas de campo, que acrescente significado para a citação ou que clarifique seu significado.

Retome os dados, reveja-as, e identifique outro padrão.

Faça uma afirmação baseada no segundo padrão encontrado.

Escreva uma afirmação, citação e comentários interpretativos complementares como descrito anteriormente. 
Quando o etnógrafo realiza este exercício, inúmeras vezes, verifica que os dados coletados transformam-se de um conjunto amorfo de textos, áudios e vídeos em dados significativos reveladores do conteúdo que quer expressar muito perto dos atores investigados. Isto é o dado só é dado quando transforma-se em dado, quando fala com o pesquisado sobre seu significado imediato para o conjunto do fenômeno estudado. 


\section{Tarefa 5 Onde está a ideia nova?}

A inovação científica como um pressuposto da pesquisa

Leia, no mínimo, quatro artigos, capítulos delivros diferentes e um livro inteiro, num campo que você não está familiarizado e em tópicos que você nunca considerou antes. Tente escolher material com alguma conexão com as ligações chaves que estão emergindo nos seu estudo, mas tente fazer disto uma conexão distante, ou pelo menos abstrata. Por exemplo, se questões sobre as relações entre supervisores e supervisionados salientou-se no seu estudo, procure por um artigo num pequeno número de textos em supervisão e moral numa tropa do exército, com o sargento como supervisor e os soldados como supervisados. Ou encontre um artigo sobre as relações de supervisão entre médicos e enfermeiras em um hospital.

Para esta tarefa, evite ler artigos sobre escolas. Você já sabe muito sobre elas e já tem muitas coisas como certas sobre escolas e educação. Encontre qualquer outro assunto (institucional ou local) diferente da escola para ler sobre ele. Porque nós assumimos que você já está consideravelmente familiarizado com o campo de psicologia, você não deve ler artigos ou livros sobre psicologia do conhecimento, psicologia da personalidade, psicologia clínica, ou desenvolvimento infantil. Você pode preferir ler artigos sobre psicologia social sobre pequenos grupos, entretanto, aconselhamos que você leia algum artigo em ciências sociais - antropologia, sociologia, ciência política, história social, e possivelmente economia. Você pode também procurar por artigos de ciências sociais em arquitetura, medicina, legislação, justiça criminal, negócios, governo, estudo de comportamento animal (etologia) e em ecologia de plantas e animais.

Para cada item que você escolheu para ler, apresente uma citação bibliográfica completa e uma breve anotação do conteúdo do item. A anotação deve conter aproximadamente três sentenças sumarizando o ponto mais importante ou os pontos mais importantes da leitura e aproximadamente duas sentenças relatando o que você aprendeu sobre a leitura e que foi relevante para o seu estudo. 


\section{Tarefa 6 Rascunhando o relatório final}

A produção científica

Introdução: descrever o problema da pesquisa, as questões da pesquisa, e o significado do estudo - planeje ser o mais breve possível, você pode sempre expandir este item mais tarde.

Visão geral sobre o local escolhido: descrever sua situação em relação à instituição ou comunidade estudada; atividades maiores durante o ano, a semana, e diariamente; o local físico - mapas, sinopses, tabelas e gráficos são apropriados para esta função, neste momento você pretende dar uma visão por exemplo, de uma distância de $30.000 \mathrm{Km}$. para $5.000 \mathrm{Km}$ ou para uma visão mais ampliada.

Descrição e interpretação: afirmações mais importantes, as ilustrações produzidas através das vinhetas e citações diretas, acompanhadas de material de ligação e interpretação.

Sumário e conclusões: inclua as discussões sobre as interpretações alternativas para os dados, o significado das interpretações encontradas, questões deixadas de lado ou sem respostas, novos questionamentos, futura direção para a pesquisa.

Autobiografia intelectual: comece com a questão que inicialmente era a mais importante, uma discussão de como o seu pensamento mudou, como procurou por des-confirmações das evidências que você investigou, como os caso discrepantes foram considerados, como perspectivas teóricas mais recentes contribuíram para a análise, etc.

Ensinando sobre os resultados: escrever algo específico sobre como você planeja ou como já comunicou os resultados do que foi estudado. Imagine que a sua audiência deve ser a comunidade científica de modo geral e ao mesmo tempo as pessoas simples. Se conseguir fazer com que pessoas simples (não-acadêmicas) entendam os seus resultados você está pronto para qualquer audiência. Entretanto, se estes resultados são apenas dirigidos a uma audiência acadêmica você pode estar falando de maneira abstrata que leva, muitas vezes a reduzir os longos anos de dedicação do seu trabalho a uma prateleira de biblioteca da sua universidade ou a sua própria. 


\title{
Tarefa 7 Quadros sinópticos, tabelas e gráficos
}

Não abuse das tabelas, mas não as deixe de lado.

Conte a frequência - após vários dias de observação, durante o tempo de observação e comparando os vários dias -para determinar padrões nos seus dados.

Faça duas afirmações baseadas nos padrões que você descobriu. Ilustre cada afirmação com um gráfico de barras, tabela de contingência, ou outro tipo de tabela de frequência simples. Apresente estas com pelo menos um parágrafo de discussão explicativa.

Faça dois quadros sinópticos, os quais possam ilustrar padrões ou afirmações de seus dados. Apresente estes acompanhados de uma discussão explicativa - escreva pelo menos um parágrafo.

Nota - Quando você apresenta ao leitor uma tabela de frequência ou quadro, você deve sempre considerar cuidadosamente o conteúdo do título - de modo que a afirmação seja clara no título. Na discussão que acompanha o quadro ou tabela, informe ao leitor em que ele deve prestar uma atenção especial dentro da tabela. Por exemplo:

\begin{abstract}
"notei que durante os últimos três dias eu observei que quando o professor estava terminando a unidade de eletricidade, somente um terço dos muitos comentários irrelevantes feitos pelos alunos apareceram nas notas de campo, comparando com as vezes que este tipo de comentários apareceram nos três primeiros dias em que esta unidade foi ensinada. Isto sugere que ....”.
\end{abstract}

Os quadros, sinópticos, tabelas e gráficos devem, preferencialmente, serem originais e construídos com o fim específico de consubstanciar dados relevantes para significar os resultados da pesquisa. Isto é, dados e tabelas construídos por outrem ou retirados de estatísticas e relatórios não devem ser utilizados. Entretanto, podem ser descritos e informados na referência para comparação e validação dos seus próprios dados. 


\section{Tarefa 8 Como meu pensamento mudou desde o início da pesquisa}

Autobiografia intelectual - mudança no processo.

Escreva um rascunho de um ensaio com o título acima. Este ensaio vai se tornar a seção final do seu relatório. Em não mais de cinco páginas, escreva sobre as questões da pesquisa, orientação teórica, pressupostos baseados em experiência anterior, valores e credos aprendidos e qualquer coisa mais que mudou desde de que você iniciou o estudo como resultado de experiências ou leituras que você fez.

Lembre-se, um bom indicador da qualidade da sua análise é o modo no qual seu pensamento mudou durante o curso da pesquisa. Isto mostra que você estava aberto a novas informações, desconfirmando informações, procurando novas perspectivas teóricas, e não apenas fazendo trabalho de campo para documentar as pressuposições favoritas com as quais você iniciou a pesquisa. Estas suposições podem permanecer até o fim, mas elas devem pelo menos serem vistas sob uma nova luz depois de você realizar o trabalho de campo, tendo lido uma nova literatura, e tendo gasto tempo refletindo sobre seus dados. Além disso, novas pressuposições e questionamentos devem ter emergido. Tudo isso pode ser emocionalmente difícil, seja franco e mencione isto também, em termos específicos sem deixar que essas dificuldades e impasses ocorridos durante o processo de pesquisa se transformem em um muro de lamentações. O leitor do seu texto está interessado no que você encontrou e não no que não conseguiu encontrar no processo, mas no que facilitou a pesquisa e nas eventuais dificuldades.

No seu ensaio, seja o mais específico que você puder sobre como as questões da pesquisa e as pressuposições mudaram e qual foi a experiência ou leitura que o levou a mudar de ideia. 



\title{
A pesquisa em colaboração com o professor: vivências de campo em etnografia crítica de sala de aula
}

\author{
Carmen Lúcia Guimarães de Mattos
}

Este capítulo apresenta o relato de experiências sobre a colaboração em pesquisa entre professores e pesquisadores. Utiliza dados da pesquisa etnográfica "Fracasso Escolar: imagens de explicações populares sobre 'dificuldades educacionais' entre jovens de áreas rural e urbana no estado do Rio de Janeiro" desenvolvida no período de 89 a 94. Descreve como a prática colaborativa pode ser essencial para a facilitação e transformação das relações de interação em sala de aula, ao considerar que o professor colaborador é um agente na pesquisa, isto é, um investigador de sua prática cotidiana de sala de aula que contribui para formular e responder as suas questões práticas da pesquisa juntamente com os pesquisadores. A inter-relação entre a pesquisa e o ensino é vista como parte fundamental do processo de construção de conhecimento em sala de aula e a colaboração como uma prática que possibilita a genuína ajuda mútua e o intercâmbio entre o trabalho de pesquisa e o ensino. Neste contexto, a abordagem etnográfica de pesquisa, em especial a etnografia crítica de sala de aula é um instrumento valioso de investigação e análise do processo de ensino e aprendizagem e que quando associada a um trabalho de colaboração tem resultados que podem mudar qualitativamente a relação entre o professor e o aluno. Entende que tanto a etnografia crítica de sala de aula quanto a colaboração entre o professor e o pesquisador, na pesquisa educacional, constituem-se como elementos para um avanço na pesquisa educacional no Brasil merecendo especial atenção entre pesquisadores nesta área de estudos. 


\section{A colaboração no contexto da pesquisa educacional}

Professores como pesquisadores de sua própria sala de aula e/ou de sua prática pedagógica não é uma novidade entre nós. Professores experientes utilizam este recurso como uma forma de aperfeiçoamento profissional; os menos experientes, para dividir suas dificuldades com seus pares e receber ajuda para diminuir estas dificuldades. No âmbito da pós-graduação, também encontramos trabalhos de tese que descrevem o professor como pesquisador de sua própria prática (SILVA, 1990). No início dos anos 80, pesquisas sinalizavam para o professor como uma parceria importante a ser construída com o pesquisador de sala de aula (ERICKSON, 1986; BOLSTER, 1983). Ressaltam estes autores, que a pesquisa etnográfica, por sua natureza interpretativa, é intrinsicamente democrática e constitui-se num deliberado envolvimento do pesquisador no local da pesquisa, o qual observa com atenção especial as questões que o professor formula na rotina de sala de aula. Ressaltam, ainda, que professores experientes servem de modelos para os menos experientes e que o entendimento dos papéis sociais do professor em sala de aula e do significado que estes papéis têm para o contexto maior da escola constituem-se numa fonte inesgotável de informações para o entendimento dos processos interativos em sala de aula. Entende-se que os professores, por excelência, poderiam descrever o significado da ação local de sua tarefa pedagógica. O trabalho de campo em pesquisas etnográficas requer habilidades de observação, comparação, contraste e reflexão sendo utilizadas de maneira sitematizada e de modo deliberado. Portanto, o professor pode e deve pesquisar sua própria prática. A importância da parceria professor/pesquisador bem como a presença do pesquisador evidencia-se porque a prática cotidiana torna-se invisível para aquele que está imerso nela. Neste caso, uma pessoa "de fora” pode ajudar a ver mais claramente as complexidades que envolvem as ações cotidianas. No entanto, esta parceria nem sempre é fácil de ser estabelecida.

Nos anos 90, pesquisadores de sala de aula começam a atribuir maior valor a participação dos professores na pesquisa. Daí estas relações serem ainda frágeis e sensíveis no tocante à 
sua legitimidade e validade na pesquisa educacional. Pesquisas relacionadas ao cotidiano escolar começam a envolver professores, a falar sobre eles, mas não com eles.

A abordagem etnográfica por sua natureza descritiva da realidade, rigorosa quanto ao entendimento do significado das ações sociais para o outro, quando associada a uma visão crítica da justiça social enquanto abordagem teórica, não pode deixar de reinvidicar a parceria do professor para a análise dos processos interativos de sala de aula. Fazer etnografia crítica de sala de aula sem o professor é continuar a falar sobre a realidade do professor sem que o professor possa sequer opinar sobre o significado de sua prática. Os professores, diferentes de outros profissionais como os advogados, médicos, engenheiros, dentre outros, não têm tido a oportunidade de manifestarem as dúvidas e acertos de suas práticas de sala de aula de modo institucionalizado, isto é, suas reflexões contam muito pouco ou não contam quando das reformulações dos planos pedagógicos institucionais (propostas curriculares e planos educacionais). São igualmente desconsiderados pelos pelos pesquisadores que investigam a escola e a sala de aula que optam por apresentar nos resultados de seus estudos "o sistema” como responsável pela situação em que se encontra a educação. Professores, enquanto profissionais, têm tido uma postura institucional pouco reflexiva como se não fossem profissionalmente capazes de pesquisarem sua própria prática ou proporem soluções para o campo pedagógico. De forma contraditória, politicamente nos movimentos de classe os professores são percebidos como atuantes em favor da Educação, experientes e combativos. Entretanto, o mesmo não é observado com relação à sua prática pedagógica, sendo considerados despreparados para lidar com a diversidade da escola e da sala de aula necessitando de treinamentos e reciclagens. É neste cenário que é delineada a figura do professor como incapaz de atuar em colaboração com pesquisadores ou mesmo de realizar pesquisas envolvendo sua prática.

A pesquisa em colaboração com o professor estabelece uma parceria entre as universidades e a escola, possibilitando que as pesquisas educacionais sejam mais relevantes e eficazes na 
reversão do quadro de falência educacional. Através desta parceria, o professor como pesquisador torna-se um ator social importante para a facilitacão não só das pesquisas nas escolas, mas também na determinação do que é importante a ser pesquisado na sala de aula e fora dela. Acreditamos ainda que a etnografia crítica de sala de aula e a colaboração entre o professor e o pesquisador é uma condição indispensável para o avanço na pesquisa educacional. A inter-relação entre pesquisa e ensino é parte fundamental do processo de construção de conhecimento sobre a sala de aula e a colaboração como uma prática que possibilita a genuína ajuda mútua e intercâmbio entre o trabalho de pesquisa e ensino.

Colaborar significa trabalhar junto de modo que possibilite o intercâmbio de ajuda mútua. Esta deve ser genuína e não apenas uma ação-ajuda, manifestando-se através dos gestos mutuamente úteis. O professor pesquisador deve estar empenhado na reformulação de sua prática de forma consciente e deliberada de forma que a pesquisa por ele realizada em conjunto com o pesquisador possa contribuir para uma mudança nas ações pedagógicas, especialmente as de caráter interpessoal. O professor que procura nesta parceria uma nova receita de trabalho está tão equivocado quanto aquele que acredita em reciclagem pedagógica como condição necessária para a reformulação de sua prática. Depositar na pesquisa a solução dos problemas pedagógicos pode ser considerado, no mínimo, romantismo. O que se consegue, muitas vezes, com esta parceria é a reflexão sistemática e deliberada sobre os pontos que o professor e o pesquisador acreditam representar o nó do processo de ensino-aprendizagem em sala de aula ou fora dela, consegue-se ainda a visualização conjunta de possíveis formas para se desatar este nó. Esperar mudanças radicalmente miraculosas, neste processo, é cair novamente na falácia de que existe um modelo certo para um bom desempenho profissional. 0 pesquisador igualmente, deve estar consciente de que este instrumento de pesquisa contribuirá para descrever apenas uma pequena parcela de todo o processo de ensino e aprendizagem que se dá na sala de aula, mas que, por sua complexidade, tem os seus tentáculos nos vários contextos sociais e ideológicos, nas 
relações face a face, na família, na mídia, no partido político, na comunidade de bairro, nos rituais religiosos, dentre outros. Portanto, é necessário o uso da colaboração como instrumento de pesquisa etnográfica crítica de sala de aula, como também é nessário o estudo mais sistemático dos macro sistemas que determinam as relações de sala de aula como a política escolar, as relações de poder, as estatísticas da fome e da miséria, a análise das relações entre a escola e sociedade mediada pela crítica sobre a justiça social, dentre outras. Estes estudos podem igualmente se realizar através de parcerias, obviamente com outros protagonistas sociais que desfrutam de igual importância para o entendimento da sala de aula e da escola - diretores, legisladores, administradores, gestores.

\section{Sobre o significado da colaboração para pesquisadores e professores}

Primeiro, sobre a colaboração entre professores e pesquisadores, deve-se notar que a colaboração significa para o pesquisador um salto qualitativo na busca do entendimento do significado da ação do outro. Em sua forma compartilhada ganhou uma nova dimensão, a da negociação do significado e da participação não invasiva, mas livremente consentida que como tal está imersa no comprometimento, na responsabilidade com a transformação da realidade cotidiana da sala de aula. Segundo, é igualmente necessário mencionar que ela não significa que a colaboração não foi um processo de alcance de pleno acordo entre participantes, nem foi o exercício de um acordo sobre metas e ações pré-estabelecidas mediadas pelas práticas curriculares ou pela organização funcional da escola. Ao contrário disso, foi uma negociação contínua e difícil, sobretudo dos diferentes pontos de vista entre os participantes, com o objetivo de compreender esses enfoques e melhorar a educação nas escolas.

Neste estudo apresentaremos dois exemplos nos quais buscamos a colaboração como estratégia de pesquisa. Durante o período de novembro de 1992 a dezembro de 1993, a equipe do "Projeto Fracasso Escolar" trabalhou na coleta de dados que 
incluía, entre outros aspectos, estudos sobre a construção do fracasso escolar na sala de aula. Buscamos parcerias nas salas de aula, consideradas pelos gestores como problemáticas, e encontramos duas professoras dispostas a colaborar com a pesquisa. A nossa expectativa era trabalhar com classes da antiga primeira série, mas esta parceria voluntária só foi possível, coincidentemente, nas duas escolas estudadas, com professoras de quarta série. A da professora Nice, da Escola da Roça, que assim passaremos a chamar por tratar-se de uma escola rural no estado do Rio de Janeiro e a da professora Bárbara, da Escola da Favela, que assim foi denominada por estar localizada na cidade do Rio de Janeiro e atender a uma clientela de 99\% de alunos da Favela da Rocinha. As duas professoras que participaram colaborativamente da pesquisa, informaram que nas suas classes o número de alunos fracassados seria de, no mínimo, 25\%.

Diante do percentual apresentado pelas professoras quanto ao quantitativo de alunos em situação de fracasso a sala de aula passou a ser acompanhada sistematicamente pela equipe de pesquisa buscando explicações para a situação desses alunos. No entanto, a busca por tais explicações não teria sentido sem a participação das professoras, pois acreditávamos que elas não tinham a deliberada intenção de levar seus alunos ao fracasso e que os mecanismos que as levavam a isso eram a elas imperceptíveis. Nesse sentido, acreditávamos que a pesquisa em colaboração poderia tornar as explicações para o fracasso escolar mais visíveis para tanto para as professoras quanto para a equipe de pesquisa. Portanto, foi necessário o acompanhamento da produção do fracasso destes $25 \%$ dos alunos das classes e, através das ações pedagógicas, entender a natureza de uma predição tão drástica e, ao mesmo tempo, tão contraditória.

Ressaltamos que a colaboração em pesquisa requer, dentre outros requisitos, a atenção de ambas as partes para a realização de um trabalho efetivamente em parceria. Neste sentido, podemos destacar que a colaboração estabelecida com a Escola da Favela foi melhor estabelecida e bem sucedida. Na Escola da Roça por serem as visitas menos frequentes 
do que na Escola da Favela a equipe não estabeleceu o mesmo nível de colaboração, não permitindo estabelecer uma relação de efetiva troca entre os pesquisadores e a professora. Portanto, o relato que se segue descreve a colaboração entre a equipe de pesquisa e a Escola da Favela na classe da professora Bárbara.

\section{Relatos de campo sobre a colaboração entre pesquisadores e professores}

Momentos de avanços e recuos marcaram este relacionamento colaborativo. Avanços quando nos aproximávamos (pesquisadores e professora) de uma parceria genuína, realmente colaborativa; recuos quando, temerosos da perda desta parceria tão importantes para nós, silenciávamos, diante das nossas próprias dificuldades em lidar com este novo tipo de relacionamento. Foram nestes momentos que os dilemas mencionados no início deste estudo ficaram mais evidentes. Um dos dilemas foi quanto a determinação dos procedimentos de pesquisa. De modo que nos questionávamos: Como poderiamos planejar com antecedência o contexto interativo que seria observado e que pudesse responder às questões maiores da pesquisa, se havíamos convidamos a professora como parceira desta observação?; Como continuar a sentí-la como um objeto se ela era parte integrante da equipe de pesquisa?; Como poderíamos confiar na professora como sujeito agente do processo questionador da equipe? A necessidade de uma autoridade compartilhada era colocada em dúvida, pois não queríamos ser interpretados nem como "autoridades no assunto" nem tampouco gostaríamos de passar uma idéia de que estávamos "tirando o corpo fora" e deixando o professor sozinho como pesquisador. Neste contexto outra necessidade emergiu quanto a estabelecer limites para preservar a integridade de cada membro da equipe, membros inexperientes que interpretavam a resistência da professora como descontentamento pessoal com a equipe. Perguntávamos como posturas conflitantes, entre pesquisadores e professora, poderiam conviver em colaboração quando havia necessidade de negociação do significado da 
ação pedagógica, para que se pudesse prosseguir na busca do entendimento do cotidiano de sala de aula. Estes foram dilemas e conflitos inerentes a posturas igualmente valiosas e tensões vividas continuamente na prática pedagógica pela professora e pela equipe de pesquisa.

A professora Bárbara é graduada e à época da pesquisa era aluna de um curso de pós-graduação. Um ponto comum entre ela e a equipe foi o interesse em pesquisa, condição necessária para o desempenho acadêmico da professora e que despertou seu interesse na pesquisa. No entanto, quando a equipe entrava em sala de aula, mesmo que sempre com consentimento prévio, era possível perceber uma expressão desagradável por parte da professora sendo a negociação de nossa presença em sala de aula um fator de estresse entre nós. A equipe preferia chegar cedo e permanecer todo o tempo, enquanto a professora preferia ter "um descanso" de nossa presença pelo menos uma parte do tempo de aula. Sempre que possível a professora adiava nossas visitas ou perguntava "será que eu ainda faço parte desta pesquisa?” quando inadvertidademente nos encontrava nos corredores da escola. Dentro deste clima de constante negociação do acesso e permanência da equipe em sala de aula aprendemos que é difícil não sermos considerados “espiões perigosos” da prática pedagógica, como se inerente ao papel de pesquisador estivesse o papel de delator dos erros do professor.

A professora sempre expressava uma atitude defensiva em relação às atividades programadas para os dias agendados para a pesquisa. Ela costumava comentar "eu estou dando isso hoje porque estamos um pouco atrasados com a matéria, não dá pra adiantar e eles ficarem perdidos né!” Não raro ela explicava para a equipe "estes eu tenho que deixar de lado, pois você sabe eles não querem nada e eu tenho que investir naqueles que têm alguma coisa para trabalhar" (referindo-se ao grupo de 10 alunos entre os 42 da classe, que desde o último conselho de classe de 1992 haviam sido diagnosticados como "os problemas da classe" e haviam sido tomados como "um desafio” pela professora Bárbara para o ano letivo de 1994. 
Foi em relação a este grupo que contraditoriamente os nossos conflitos (da equipe com a professora) mais se evidenciaram. Em abril, ela já demonstrava sinais de enfraquecimento na determinção de "converter" esses alunos a um status de "regulares" na classe. No primeiro conselho de classe, por exemplo, ela por várias vezes solicitou às outras professoras depoimentos que demonstrassem o quanto era difícil conseguir algum progresso com estes alunos, falando "você viu né Regina (professora da $3^{\mathrm{a}}$ série), vocês são testemunhas que eu faço o que eu posso, mas eu não sou a palmatória do mundo, tem casos que eu não posso ajudar”. Em nenhum momento a professora discutiu com a equipe sobre sua estratégia de aula, considerada pela escola (diretores, orientadores, professores e alunos) como professora experiente, batalhadora, "boa professora”. Ela não questionava, assim como a equipe, se o que estava sendo realizado em sala de aula era importante para os alunos, se o fato de ela ter um grupo seleto de "10 alunos problemas" era um consenso da classe. Diferente da equipe que considerava o ato de ensinar e aprender dialeticamente, ela entendia a tarefa de ensinar de forma dicotomizada da tarefa de aprender e considerava que a equipe de pesquisa estava ali para ensinar o que deveria ser feito ou aprender com o que ela fazia, descrever o sucesso dela em lidar com "os problemas" de forma enérgica e eficaz para a escola (manter os alunos "com dificuldades" longe da secretaria e ocupados "de alguma forma" na sala de aula).

A equipe, meio tímida ainda, esperava pacientemente que a professora tivesse "alguma dúvida" sobre a ação pedagógica em sala de aula, pois nós tínhamos muitas e estas foram silenciadas ora por medo de romper a parceria, ora por respeito ao ponto de vista da professora. A professora portava-se como que tentando ensinar à equipe de pesquisa o que é ser um "bom professor" para este "tipo de aluno". O nosso objetivo era que ela formulasse algumas perguntas sobre o que estava acontecendo na sala de aula, alguma coisa que ela não compreendesse bem sua relação com os alunos e alunas e que explicasse o fracasso daqueles alunos, especialmente "os dez mais problemáticos". A professora, por sua vez, parecia não ter dúvidas, ao contrário, falava com certeza que as causas do 
fracasso escolar tinham a ver com o passado desses alunos em outras turmas, com outras professoras, escolas "diferentes,” com a origem pobre de suas famílias faveladas, com 0 desinteresse deles e dos pais pelas questões da educação e, especialmente, com a falta de uma "educação doméstica” voltada para a escola. Tinha muita certeza sobre sua eficiência, às vezes reconhecida e estimulada pela direção da escola, que embora não concordasse plenamente com seus métodos, reconhecia ser "um alívio" ter uma professora "disposta a enfrentar" uma classe como tantos "casos problemáticos.” A classe da professor Bárbara era de alunos repetentes. Somente 7 dos 42 alunos não eram repetentes, a média de idade era de 14 anos variando entre 12 e 17 e regularmente, esta classe tinha alunos na faixa etária de 10 e11 anos.

Outro espaço observado na Escola da Favela foi o das reuniões do Conselho de Classe. Como as reuniões envolviam os demais professores e gestores da escola a presença da equipe foi igualmente negociada com os demais professores que permitiram nossa permanência. No Conselho de Classe do segundo bimestre um tema comum entre as outras classes da escola não foi mencionado pela professora Bárbara: vários professores reclamaram das brincadeiras ditas sexuais entre os alunos na escola e na sala. Os professores não descreveram os detalhes das brincadeiras indicando a necessidade de serem pensadas soluções para elas. Destacamos no comentário sobre as brincadeiras sexuais que a turma da Bárbara era composta por alunos de idade mais avançada e que, por esse motivo, poderiam ter mais problemas do que as outras com relação à sexualidade. A turma da Bárbara foi considerada pelos demais professores como um exemplo para as outras por saber como "lidar melhor com esses assuntos", como afirmou a coordenadora pedagógica para o grupo durante a reunião.

Este fato fez com que a equipe sentisse a necessidade de estudar mais de perto os alunos da classe da Bárbara, acentuando ainda mais nossas relações conflitantes. Queríamos saber melhor como eles eram, o que faziam, como viviam, que conhecimentos tinham sobre a vida adulta: família, trabalho, diversão, sexo, droga, dentre outros estes eram os temas que 
queríamos ouvir dos alunos. Bárbara ficou muito assustada com a proposta, chegando mesmo a impedir, por um tempo o nosso acesso à sala de aula e, em particular, aos alunos para a realização de entrevistas.

Diante da negativa de Bárbara pensamos, inicialmente, em distribuir um questionário, que foi vetado por ela por considerar os alunos "imaturos" para as questões nele propostas (especificamente aquelas que perguntavam sobre o conhecimento dos alunos em relação ao uso de drogas e sexo). Eliminamos o questionário e tentamos uma redação que versava sobre o tema "A vida de um menino na cidade do Rio de Janeiro". A realização da redação foi consentida pela professora e solicitada aos alunos. Após o estudo das redações, solicitamos que a professora liberasse alternadamente os alunos para a realização de entrevistas. No primeiro momento, a "colaboração" por parte da professora foi dificultada pela desconfiança quanto ao que seria perguntando aos alunos. Ela, antes de liberá-los, os prevenia sobre as possíveis questões basedas no questionário que não aplicamos e sugeria algumas respostas, além de tentar controlar a formação dos pares de alunos que deveriam ir juntos para as entrevistas, o que, segundo ela, evitava combinações "desastrosas." Ela falava: "estes dois juntos Deus me livre! É melhor separar, senão só sai asneira”. As entrevistas etnográficas permitiram que os próprios alunos falassem espontaneamente sobre suas vidas direcionando as perguntas a serem feitas. $\mathrm{O}$ desenvolvimento das entrevistas sem afetar o cotidiano da sala de aula permitiu o reestabelecimento da confiança entre a professora e a equipe de pesquisa que quando do término das entrevistas já não se importava mais com o fato. Aprendemos com as entrevistas que, ao contrário, do que havia ocorrido no Conselho de Classe, a turma da Bia também brincava das mesmas coisas que as outras, só que por temer punições conseguiram esconder o fato sem deixar vestígios. Descobrimos ainda que, como era de se prever, os alunos da Bárbara tinham experiência sobre sexo e drogas que não coincidiram com o perfil descrito pela professora. Bárbara evitava "esses assuntos" temendo aguçar a curiosidade dos alunos sobre tais assuntos. 
Vale ressaltar que aprendemos muito na colaboração com a professora Bárbara. Ela, muitas vezes, mencionou sua desconfiada em relação ao uso que se possa fazer das informações obtidas em sua classe, pois de maneira geral o professor é visto como "o vilão que leva o aluno ao fracasso", seja por "incompetência técnica" ou "descompromisso político". No entanto, ela corajosamente permitiu que nossa equipe compartilhasse a convivência em sala de aula. Bárbara sabe que dentro de seus próprios limites ela é uma "professora" com todas as letras e desconhece o "por que" do fracasso de seus alunos. Aprendemos que tínhamos que ter a coragem que a Bárbara teve e, arriscar mais nesta parceria, já que fomos nós que a propusemos, que deveríamos ter confiado em nossa capacidade de negociar ao avaliar que perdemos com isso oportunidades mútuas de estudo e discussão. Foi somente no final do trabalho de campo que isso ficou mais evidente quando da participação no último Conselho de Classe.

Durante o último Conselho de Classe, Bárbara, como estava previsto desde o início do ano, "teve" que reprovar os "dez alunos problemas" e passou "maus bocados" perante o grupo de professores e gestores para manter-se coerente diante das decisões que tomara. Foi solicitado que ela considerasse algumas aprovações desses alunos. Entretanto, ela "consciente" do papel que desempenhara o ano inteiro (o de tomar conta e dar conta "dos alunos problemas") informa ao grupo dizendo "bem, eu fiz o que pude, mas aprovar é fora do meu alcance, vocês me entendem, eles não sabem nada, como é que vão para a $5^{\circ}$ série assim, depois bate na mão de alguém que não me conhece vai pensar que eu não dei aula.” Diante do solitário papel de "carrasco" que lhe fora atribuído, não restou à equipe outra alternativa a não ser a de interferir em favor da professora. Neste momento tentamos ressaltar, com as dados das observações realizadas, a coerência entre o ato de reprovar os dez alunos e a prática que ela havia desenvolvido durante o ano letivo, quando os demais colegas só lhe exigiam uma postura rígida de controle da turma, sem levar em conta outros fatores que ora eram reivindicados pela direção como pontos fundamentais para a tomada de decisão sobre o destino daqueles 
alunos. A professora, após ouvir nossa intervenção comentou “agora, sim, valeu, ganhei o meu dia, valeu a pena”. Para nós a fala de Bárbara representou, naquele momento, o reconhecimento de que ela tinha construído uma parceria genuína. Foi gratificante para a equipe de pesquisa perceber que a professora encontrou em nós um aliado.

Inúmeras passagens poderiam ser relatadas nas quais os limites do processo de colaboração convergiram e divergiram durante a realização do trabalho de campo, como indicam as categorias diálogo, confiança e risco que emergiram das análises do estabelecimento da colaboração entre a professora e a equipe de pesquisa.

\section{O diálogo}

Aprendemos com esta experiência que na pesquisa colaborativa o diálogo face a face é um componente indispensável para a construção de uma colaboração genuinamente de mútuo interesse. A conversa clara e aberta sobre as intenções, expectativas, opiniões e preocupações que envolvem o trabalho de pesquisa e a tarefa pedagógica do professor devem ser amplamente debatidas e compartilhadas, ora de forma sistemática e planejada, ora de maneira informal e espontânea em reuniões e conversas.

A experiência em pesquisa etnográfica evidencia que o pesquisador fica inibido tentando manter a postura de "não interferir no contexto" perdendo assim a oportunidade de aprofundar no entendendimento do significado da ação do outro e cometendo assim erros de interpretação que podem perdurar durante muito tempo até que sejam detectados. Com este envolvimento aberto ao diálogo, o pesquisador pode evitar julgamentos precipitados recebendo a ajuda do professor e interpretando de forma mais coerente a natureza das suas ações cotidianas.

Pesquisadores e professores abertos ao diálogo promovem uma relação mais simétrica em termos de poder - relação pesquisador/pesquisado. Uma relação assimétrica de poder é 
quase sempre inerente ao processo de pesquisar, impedindo com isso uma colaboração completa. Na entrevista etnográfica, por exemplo, o etnógrafo repete a fala do professor, parafrasendo o entrevistado de modo a evitar a inclusão de conteúdos agendados pelo pesquisador e distantes do contexto do professor visando não interferir na resposta do professor. No entanto, em colaboração a agenda deve ser de ambos, que em diálogo, sistemático (entrevista) ou não, conversam e compartilham relatos de suas práticas profissionais. Neste caso, uma limitação quanto a não expressar sua própria opinião ou falar sobre sua própria experiência ficam liberadas, promovendo um diálogo no qual o compartilhamento de ideias tem igual peso na colaboração entre o professor e o pesquisador.

\section{Confiança e risco}

As categorias de análise confiança e risco no contexto do estudo sobre a colaboração aparecem juntas por seu caráter interdependente. Não há colaboração sem confiança. Esta de uma forma ou outra envolve riscos. A confiança pode estar relacionada ao fato de que o pesquisador sabe alguma coisa que o professor não sabe (geralmente o pesquisador tem maior grau de escolarizacão e não raro carrega o mito de ser "o cientista" e portanto aquele que "faz ciência") o que pode sinalizar ao professor a possibilidade de ajuda, conselhos, soluções para os seus problemas. Porém, aconselhar professores sem este ter sido solicitado não é colaboração. De outra forma se os pesquisadores apenas se mantivessem calados e concordassem completamente com a agenda estabelecida pelos professores, esta atitude não seria colaborativa porque envolveria falsidade, seria um silenciar não autêntico de opiniões da equipe. Ambos, professores e pesquisadores, possuem peças do quebra-cabeça, mas as peças são diferentes. Portanto, temos que confiar no conhecimento mútuo sobre determinado tema também de interesse mútuo. 0 pesquisador, por sua vez, tem que confiar que 0 professor será fiel à parceria, que estará aberto às perguntas da pesquisa, que acredita que o professor sabe sobre sua prática, embora muitas vezes não tenha as informações arrumadas da 
forma que o pesquisador as têm, confiar que o professor pode descrever e solucionar problemas que os pesquisadores não estavam atentos. $\mathrm{O}$ risco na confiança conduz a momentos de recuos e avanços, onde, às vezes, se tem certeza e em outras dúvidas sobre uma mesma ação ou procedimento. Como explicar que um professor consciente de sua tarefa de educador possa reprovar um aluno com base no mau comportamento deste alunos? Como confiar na certeza do professor sobre a sua prática quando este acredita ter um "aluno problema" e ao mesmo tempo usa de ironia durante quase todas as aulas de um ano letivo, demonstrando descaso pelo "problema deste aluno"? Discernimento sobre os problemas da escola, em geral, podem nos ajudar a conviver melhor com estes dilemas, mas nós não devemos esperar que mesmo um profundo discernimento irá promover um arranjo para as soluções dos dilemas da ação colaborativa na pesquisa. É preciso, definitivamente, conviver com os dilemas. Confiar no professor e na equipe de pesquisa que, através de uma colaboração mútua, compartilham suas certezas e incertezas contruíndo a colaboração de forma genuína e duradoura.

\section{Concluindo}

Analisando as condições de desenvolvimento da pesquisa etnográfica crítica de sala de aula e suas limitações no âmbito da escola básica, concluímos que esta abordagem é um instrumento valioso nas investigações do processo de ensino e aprendizagem quando associadas a uma efetiva e genuína colaboração entre professores e pesquisadores. Acreditamos que este procedimento merece maior atenção daqueles que estão preocupados em investigar o contexto de sala de aula e as interações que nele se evidenciam, em especial as relações face a face. A contribuição da pesquisa em colaboração com o professor pode oferecer outras interlocuções para repensar a pesquisa do professor. 


\section{Referências}

BOSTER, A. S. Toward a more effective model of research on teaching. Harvard Educational Review, v.53, n.3, p.294-308, 1983.

CAMPBELL, D. Collaboratioon and contradiction in Staff Development Project. Teachers College Record 90, 1988.

ERICKSON, F. Qualitative research on teaching. In: WITTOROCK, M. Handbook of research on teaching. New York: Macmillan, 1986.

LAMPERT, M. How do teachers manage to teach? Perspectives on problems in practice. Harvard Educational Review, n.55, p.178194, 1985.

MATTOS, C. L G. Picturing school failure: a study of diversity in explanations of educational difficulties of difficulties among rural and urban youth in Brazil. 1992. 268f. Thesis. (Ph. D. in Education) - Graduate School of Education, The University of Pennsylvania, Philadelphia. USA, 1992.

SILVA, T. M. N. A Construção do currículo na sala de aula: o professor como pesquisador. Editora Pedagógica Universitária, São Paulo, 1990. 


\section{Imagens da exclusão na microanálise da sala de aula: uma instância interativa de confronto cultural}

Carmen Lúcia Guimarães de Mattos

Este texto centra-se na análise da interação de sala de aula, como uma fonte de dados reveladores das práticas escolares que resultam, parcialmente, em uma batalha silenciosa entre alunos e a professora. Foi desenvolvido um estudo etnográfico por um longo período de tempo uma escola pública de ensino fundamental. Do material deste estudo foi destacado um estudo de caso da sala de aula $1^{\text {a }}$ série no contexto escolar do período de recuperação final. A partir do recorte do estudo de caso foram escritas vinhetas etnográficas. Nestas, ilustrou-se com uma análise microetnográfica, as interações, os padrões de eventos interativos entre a professora e seus alunos como um todo e em particular. Nessas interações foram evidenciados descompassos entre os processos institucionais intermediados pela professora e as formas de entendimento e realização dos mesmos pelos alunos. Essa batalha silenciosa, como caracterizou-se este estudo, desenvolveu-se em um descompasso entre os interesses e as expectativas dos alunos e da professora.

Pesquisas sobre o fracasso escolar apontam a pouca sensibilidade de professores e professoras sobre a cultura dos alunos e a indiferença dos mesmos aos problemas dos repetentes e dos excluídos. Este descompasso se constitui como um obstáculo para o sucesso de alunos e alunas nas séries iniciais do Ensino Fundamental (Andrade, 1990; Mediano, 1983; Brandão, 1982; Barreto, 1980; Patto, 1990). Entre outros argumentos, 
esses estudos mostram que os professores associam o fracasso ou o sucesso escolar às condições socioeconômicas dos alunos/ as e suas famílias, fato este que não se alterou ao longo dos anos (MATTOS; CASTRO, 2010).

Concordamos com a posição de que os professores têm poucos conhecimentos sobre a cultura dos alunos e descrevemos cenas em que eles são, às vezes, insensíveis aos problemas dos repetentes e excluídos. Inferimos que estes fatores podem contribuir, parcialmente, para a construção do fracasso de seus alunos. Estamos preocupados em descrever as percepções que os jovens fracassados têm do fracasso do qual são vítimas, pois a maioria dos estudos sobre o tema valorizam, predominantemente, as percepções dos professores. Os alunos entrevistados avaliaram que os professores tinham dificuldades para entenderem suas necessidades escolares e pessoais contribuindo para o fracasso de seus alunos. Eles consideraram ser difícil lidar com seus professores, percebendo-os como desinteressados e sem conhecimento específico da matéria a ser ensinada. Afirmaram que o interesse e conhecimento que eles esperavam que seus professores tivessem em função de serem qualificados, muitas vezes eram inexistentes e isso parece não ser considerado no processo avaliativo dos alunos. Segundo eles, a professora não é avaliada por ninguém; então como podem saber se estão sendo justos ao reprovarem seus alunos?

Os pais e responsáveis pelos alunos, isto é, aquele que se responsabiliza efetivamente pela criança segundo o Estatuto da Criança e do Adolescente, percebem o desinteresse dos professores para com os alunos e para com a escola, percebem a falta de conhecimento dos mesmos sobre os conteúdos escolares do ensino fundamental (Português, Matemática, Ciências e Estudos Sociais) como fatores que contribuem para o fracasso das crianças na escola. Contrários a eles, os professores apontam o baixo nível socioeconômico dos alunos e das alunas, além de outros fatores externos à escola, como as principais explicações para o fracasso escolar. Em sua maioria, os professores acreditam que o fracasso das crianças pobres na escola é consequência da condição ambiental na qual vivem. 
Eles também atribuem o fracasso à inadequação do currículo escolar que não leva em consideração a condição socioeconômica dos alunos. Assim, eles deslocam o problema para fora do seu próprio âmbito de responsabilidade evitando a autocrítica sobre o seu próprio fracasso em promover o sucesso de seus alunos.

Os outros participantes deste estudo (diretores, supervisores e autoridades educacionais) apontam a falta de interesse dos professores como resultante da ineficiência do sistema escolar e da demanda, legítima, de professores por melhores condições de trabalho. Eles entendem a situação dos professores como desumana por causa dos baixos salários, das salas de aula superlotadas, da falta de material escolar, dos prédios escolares inseguros e inadequados e de treinamento inapropriado. Este grupo também mencionou a falta de vontade política de gestores e governantes em resolver o problema escolar como causa para o desencorajamento de professores em suas lutas por melhores escolas e melhores condições para os alunos nas escolas públicas.

\section{A classe da professora Leonora}

O objeto de estudo deste texto é a interação entre a professora Leonora (nomes de pessoas e de escolas são fictícios) e seus alunos em sala de aula, na Escola São Sebastião. Os alunos da escola entrevistados afirmaram que os professores "batiam neles" e os "castigavam por qualquer coisa", não "ensinavam bem" e não "explicavam as lições". Em contrapartida, os professores se queixavam sobre a "falta de motivação" dos alunos desta escola de zona rural. Estas manifestações se tornaram mais visíveis a partir de observações realizadas durante os diferentes períodos em que a observação foi realizada no cotidiano dessa escola (segundo semestre de 1988 e os anos de 1992 a 1994). As situações que destacamos são de uma classe de recuperação final (15 dias letivos no final do ano de 1988) em que foram reunidas 15 crianças multi-repetentes da primeira série do Ensino Fundamental. 
Um estilo de ensino autoritário foi como caracterizamos a postura da professora observada. Em oposição a este estilo, alunos resistiram ou acomodaram-se silenciosamente. As situações de confronto entre professores e alunos em sala de aula confirmaram a fala dos entrevistados, mas serviram para direcionar a pesquisa a observar, mais precisamente, as características dessa interação e como essa "batalha silenciosa" era travada no interior da sala de aula.

O estudo da interação em sala de aula foi possível, com o uso de técnicas microetnográficas, utilizando o potencial de vídeo para coletar e analisar dados, foi realizada uma análise detalhada de cada segmento de uma aula de $40 \mathrm{~min}$. Destacamos os momentos de interação da professora com seus alunos procurando identificar seu significado. O vídeo forneceu meios para observar o tipo de interação rotineira em sala de aula de modo mais vívido e ampliado. A sua utilização possibilitou recorrer aos eventos observados repetidamente e de várias formas, através do vídeo pudemos revisitar a sala de aula inúmeras vezes e ampliar as vozes dos alunos e alunas cujos comentários durante as entrevistas eram limitados a frases curtas e queixas tímidas. Os jovens se queixaram sobre o uso rígido do poder pela professora. A ameaça e o castigo, como meio de controle na sala de aula, demonstraram que suas falas poderiam ser traduzidas nos diversos estilos comportamentais, que de uma forma ou outra comunicavam ao observador e a professora a sua reação ao que o processo pedagógico proposto era de oposição a este. No que tange aos processos sociais mais amplos, percebemos que o eco de uma sociedade autoritária pode ser ouvido através das interações dentro desta sala de aula.

\section{O dever}

Na situação que descreveremos abaixo, a interação verbal de Fátima com a classe limitou-se a momentos em que pedia silêncio aos alunos. Enquanto as crianças desenvolviam a tarefa a professora andou entre as carteiras parando ocasionalmente perto de uma criança e falando:

Tá tudo errado! Conta direito! Já acabou a tabuada ? Senta direito! Cala a boca! Tá tudo errado! 
A tarefa na qual a turma estava trabalhando envolvia copiar do livro texto (cartilha) e escrita de números. Alguns alunos estavam escrevendo números em uma sequência regular; de 1 a 150 , de 150 a 200 e de 200 a 300 . Outros estavam alternando as sequências de 2 em 2, de 3 em 3 até 100 .

A professora andava constantemente entre as carteiras dos alunos, olhando, impacientemente, para o trabalho dos mesmos e "ajudando" àqueles que demonstravam dificuldades. A professora escreveu a tarefa no quadro e no caderno de cada criança, sem dar explicações verbais sobre o que deveria ser feito. Na maior parte do tempo, tarefas diferentes daquelas que ela escreveu no quadro eram pedidas aos alunos através de tarefas escritas por ela nos cadernos.

O objetivo das tarefas não parecia estar claro para os alunos nem para a professora. Ela pediu para os alunos completarem as tarefas porque seriam parte da nota final. Esta foi a "explicação" dada pela professora à turma toda:

Olha, essa nota aí vo... vocês fizeram uma avaliação ontem. Um exercício valendo nota, não foi?! Mas com esse exercício daí mais com o que tá na secretaria. Vou dividir por 3 a nota! (Uma menina da frente entorta a boca dizendo "Ih, que coisa chata!")

Interpretando o que foi dito, a mensagem era que os exercícios eram uma espécie de "teste" cuja nota, deveria ser somada à nota final ao término do período de recuperação. Porém a professora disse que aquelas crianças seriam repetentes para o próximo ano, e que, não importava a nota que conseguissem. Assim a tarefa era feita para "matar o tempo" durante o período de recuperação.

O procedimento usado pela professora para ensinar números exigia que as crianças colocassem um traço após cada número, separando-os. A maioria das crianças não seguia a instrução. Ela repetiu a instrução três vezes com as crian- 
ças individualmente. Em um ponto a professora olhou para o caderno de uma criança e disse:

Douglas - Tá certo ? (Ela olha de um lado e do outro do caderno). Professora - Tudo errado. Pode apagar e botar os tracinhos todinhos. Que você não colocou. Tá tudo errado. (Douglas volta para seu lugar). (Ela dá uma olhada superficial no garoto que está sentado ao lado de Ronaldo. Vai para o outro lado da sala ver o caderno de Dolores. Fica alguns segundos lá passando o dever para ela depois chama a atenção de Leandro que estava distraído). Alguns minutos mais tarde Douglas é abordado pela professora em sua carteira, ela fala: Professora-Olha aqui...(diz para Douglas) coloca o tracinho aqui pra dividir, ó....! Olha aqui! Não tô entendendo Douglas, coloca os tracinhos aí direito, Douglas, pelo amor de Deus! Faz isso aqui direito. Tá tudo embolado! (vai até Gilson, pega uma folha que ele estendeu, olha e dobra em duas). Professora Não tô endendo nada! (Diz ainda se referindo ao dever de Douglas). Professora - Cola um número em cima do outro. Anda Douglas. Não tô entendo nada o que você está escrevendo! (Coloca a folha que estava em suas mãos na última carteira no lado direito).

Em outro segmento a professora ensinava sequência numérica, ela "ajudava” uma criança, mas a reação da criança foi tentar esconder a cabeça com a camiseta. Este segmento ocorre assim:

Ronaldo - Tia, vem cá (A professora vai até ele). Professora - conta, 1, 2, 3... 4, 5, 6.. depois do 6 ? $7,8,9 . . .10,11,12$ e assim vai. Depois do 12 , conta... depois do 12 vem que número? ...Depois do 12 vem que número, que número? ...13. Conta direito! 13. Conta! 14, 15. Coloca ele aqui... Não foi 15 aqui? Conta aqui. 16, 17, 18. (fala sem nehuma paciência e com rudeza na voz. Um garoto próximo de Ronaldo estende seu caderno para ela. Ela olhou sem atenção, 
colocou o caderno na carteira e começou novamente com Ronaldo). Professora - (....) conta... conta ...depois do 6 vem que número? 7, 8, 9. Depois conta, 10, 11,12. Depois vem? ...Depois do 12 qual que vem Ronaldo? ...É assim... (O garoto ao lado de Ronaldo estende 0 caderno a ela. Ela dá uma olhada, depois larga o caderno e vai corrigir de novo o caderno de Ronaldo). Professora - 15... depois do 15... Depois do 15 Ronaldo? (Ronaldo diz 13) 13 Ronaldo! Cê tá cansado de saber isso! (Diz com raiva batendo com a mão espalmada na carteira). 15, depois do 15? Que número que vem Ronaldo? Ronaldo depois do 15 que número que vem? Depois... 16, 17, 18!... Contando de 3 em 3 Ronaldo! Perde aula Ronaldo, perde! 18... depois conta... 19, 20... Depois do 20?.. (Dá um soco na mesa com a mão fechada... Ronaldo tenta esconder-se com a camisa timidamente demonstrando medo). 1, 2, 3... 4, 5, 6... 7, 8, 9... $10,11,12 . .13,14,15 . .16,17,18 . .19,20,21$. (Agora olha para o caderno do outro menino e começa a escrever. Moisés não está fazendo nada e ela bate com a ponta da caneta três vezes na cabeça dele). Professora - Dever... (Diz entre os dentes).

No exemplo acima, transcrevemos um segmento no qual a professora demonstra, em sua fala, que alguma coisa "tinha que estar errado” com o aluno Ronaldo. Durante a explicação da tarefa junto ao aluno a professora o lembra de que ele sabia contar, pois ela já havia ensinado. Além disso, a professora menciona a consequência advinda das faltas de Ronaldo às aulas "Perde aula Ronaldo, perde", reforçando a explicação com um tom de ameaça, além do soco na mesa do aluno ao que ele para sua defesa esconde-se na camisa. Desse modo, a professora ao indicar que ele não havia aprendido o que ela ensinou por conta das faltas transfere a responsabilidade de si para Ronaldo. Foi possível perceber a existência de uma dicotomização entre ensinar e aprender na interação desta professora com os alunos, separando o ensino da aprendizagem para tornar o aluno responsável pelo seu próprio fracasso. 


\section{A interação}

A fala da professora foi caracterizada por comentários que consideramos negativos: o não e o errado predominam. $\mathrm{O}$ uso exagerado de expressões negativas indica que a professora ocupava-se, predominantemente, com a manutenção do controle disciplinar de seus alunos. Após uma rápida vistoria nos cadernos, a professora reagia igualmente quanto aos acertos e erros inviabilizando que os alunos pudessem diferenciar o que estava realmente certo ou errado.

Para tentar entender este tipo de interação entre a professora e os alunos foram conduzidas três entrevistas: com a professora, com um supervisor e com um administrador da escola. A intenção era obter informações sobre a percepção deles do porquê desta forma de interação. A primeira entrevistada atribuiu os procedimentos da professora ao seu temperamento, sua personalidade, mas, contraditoriamente, explicou que estas práticas são comuns em sala de aula nesta escola. Ela disse:

Isto é normal aqui, acontece muito, mas é uma questão da professora, uma questão do temperamento da professora [..] Ela perdeu o controle, ela é muito nervosa. Você sabe [...] Os professores têm que ter vocação para ensinar, uma coisa natural que a maioria deles não tem. Você sabe! Esta "garota" (querendo dizer que ela era uma professora sem experiência) ela não tem isto assim, ela não tem paciência para lidar com repetentes, eles são lentos, eles têm dificuldade de entender o que ela diz, eles têm que ter atenção especial. Ela não pode dar isto a eles. [..] Além disto, os alunos da Escola São Sebastião, às vezes têm que andar $5 \mathrm{~km}$ para freqüentarem a escola. Eles estão cansados, eles somente querem comer a merenda escolar, é para isto que eles vêm à escola. [..] Aqueles repetentes, eles sabem que não vão passar de ano. [..] Eles não se importam. Seus pais não se importam também. [..] não é somente culpa da professora. Uma situação como aquela que você 
pode encontrar em todas as escolas rurais deste município. [...] Eu acho que os pais devem ser responsáveis, eles entregam aqueles "pobres inocentes" ao mundo e então, eles não podem tomar conta... (Geni, professora da $5^{\text {a }}$ série na Escola São Sebastião).

A segunda entrevistada explicou o ocorrido em sala de aula, apontando alguns preconceitos que os professores têm sobre alunos de zona rural. Os professores acreditam que comparando os meninos e meninas os de zona rural são menos capazes e menos competentes academicamente que os de zona urbana. Esta percepção por parte deste professores tem um grande impacto sobre como os professores interagem com alunos de escolas rurais e explica o porquê de os que são oriundos dos grandes centros não gostarem de ensinar em escolas rurais nem de lidar com crianças de zona rural. A orientadora pedagógica entrevistada disse:

Penso que os professores não estão preparados para seu trabalho. Você chega e parte para a violência. Você não está conseguindo nada. [..] (deste tipo de relação). Eu não sei ! [..] Aqueles sentimentos (de ódio) são naturalmente passados para os alunos, a professora odeia ir trabalhar em uma área rural. Ela tem um quadro ideal do aluno e sabe que na escola rural ela não encontrará este tipo de aluno. Então ela fica transtornada sobre seu emprego e passa isto para os alunos. Ela sabe que está agindo errado mas o faz de qualquer modo porque ela não percebe que está fazendo isto. Acho que se ela vir o vídeo ela não se reconhecerá nele. Ela se sentirá mal sobre ele. [..] Mas é tarde demais... (Márcia, orientadora pedagógica, Escola São Sebastião).

Do ponto de vista da entrevistada o problema na interação está associado à motivação da professora. Os professores não encontram muito incentivo para ensinar em escolas rurais, e assim, demonstram com palavras e atitudes sua frustração para as crianças em sala de aula. 
A última entrevistada sobre a interação na sala de aula foi a supervisora chefe da escola rural. Ela disse:

A falta de treinamento da professora, falta de treinamento, ela não estava preparada para aquilo (querendo dizer que ela não estava preparada para ensinar a estudantes de zona rural). Você não chega em nenhum lugar. Penso que esta é a questão. É a falta de preparo [..] é a falta de preparo, é a falta de treinamento. Eu não sei [..] Penso que ninguém nasce burro, o ser humano não nasce burro sob nenhuma hipótese. Ele pode se tornar... Eu ouvi sim...mais de um professor chamar seus alunos de "burro" ou dizer que eles não podem aprender nada... Naturalmente, já sem nenhuma dúvida, você [..] É muito cômodo você colocar sempre a responsabilidade em cima de outro. Não é. Ele (o aluno) não aprende [..] Não é porque a escola é ruim, não. É porque ele (o aluno) não está preparado, é mal preparado. Não é porque não existe estrutura dentro da sala de aula. É porque ele é burro, ele nasceu burro e nunca irá aprender. É muito fácil colocar a responsabilidade, o fracasso nas costas de outros, especialmente de uma criança, não é ?! Porque, ela (a criança) não pode se defender. Eles são vítimas. Sim, esta falta de controle, o professor vive em um estado de penúria total, a penúria que ele (o professor) encontra o faz perder muito o controle. Você entende? Eles (os professores) não têm muito controle. É uma profissãozinha que lhe pede uma grande dose de dedicação, muito amor. Isto [..] isto não é comum que alguns tenham. Este tipo de dedicação. Ela estava ali como se dissesse: "porque ela não tinha nada melhor para fazer". Ela tinha muitos problemas em casa para resolver, com um bando de crianças enchendo o saco. Você escuta isto algumas vezes. Não é fácil, o problema deste país é muito complexo. E eu continuo batendo na mesma tecla: não existe um plano político educacional sério neste país, a educação não 
é uma prioridade para ninguém. Ninguém tomou este problema e o encarou de frente. Não é ainda uma prioridade. No momento em que alguém o fizer, muitos problemas serão diminuídos, muitos [..] É somente através daquilo, através da educação, do conhecimento que você pode ter um país forte, um povo desenvolvido e uma nação desenvolvida... (Ana, supervisora escola do munícipio de Cachoeiras de Macacu, Rio de Janeiro).

A perspectiva da supervisora Ana é de que a interação entre a professora e os alunos é prejudicada pelas condições de trabalho que são oferecidas justificando a falta de controle do professor com seus alunos atribuindo a eles a culpa por seus fracassos. Explica que, de um modo geral, o país não oferecem condições educacionais que visem encarar o "problema de frente". Desse modo, perpetuam-se as interações entre os professores e os alunos como as que foram observadas na sala de aula de Leonora.

Uma característica da interação da professora Leonora com a sua turma é que a ela interagia com os alunos e alunos individualmente, dando a impressão de que ela interessava-se por cada um deles. Ela chamava cada um pelo nome, sabia onde cada um devia sentar e em que tarefa cada um deveria estar trabalhando. Sua familiaridade com os alunos era um meio de controle; para reforçar a disciplina e mantê-los trabalhando. Ela usava comentários ameaçadores durante todo o período registrado no vídeo e durante as suas aulas em outras observações realizadas em sua classe. Por exemplo, ela dizia:

... Isto é para nota !

... Você não vai sair para o intervalo Rodrigo!

... Olha para a frente ! Eu vou dar nota nisto, certo?

A ameaça era uma das características que marcaram a interação da professora em sala de aula, e foi destacada para análise juntamente com outros tipos de interações negativas: agressão verbal (gritar com os alunos) e agressão física (bater nas cabeças, mãos e carteiras dos alunos), estes eram os meios pelos 
quais esta professora interagiu com a turma durante o período estudado por vídeo - depois da criação do Estatuto da Criança e do Adolescente todas essas atitudes seriam enquadradas como crimes contra a criança. Contudo, os alunos continuavam a sair de suas carteiras e não trabalhavam a maior parte do tempo, conversavam. A resistência ao que a professora propunha era evidente quando os alunos falavam alto que não fariam o que ela lhes pedia. Por exemplo, uma aluna de cerca de oito anos disse para a colega:

Isto não [..] Eu não vou copiar isto não!

Outros alunos não diziam nada, mas não faziam nenhum trabalho também, numa atitude de resistência à produção. Uma primeira impressão sugeria que os alunos não trabalhavam e que a professora usava a nota como instrumento de pressão para obter rendimento, mas uma análise do contexto torna evidente que nem ela esperava um grau de produção que lhes levassem a superar a reprovação nem os alunos pretendiam produzir. Esta situação evidenciava a supervalorização de aspectos como: disciplina, reforço negativo, ameaça, castigo, abuso físico, indisciplina e, até, a aceitação. Tal aceitação que parecia ser considerada "comportamento adequado" para alunos de zona rural, pode ser interpretada como uma forma de resistência passiva ao comportamento da professora em sala de aula.

\section{Considerações finais}

Sendo esta uma "turma de recuperação", a professora parecia considerar a agressão física, ameaça e agressão verbal como uma das únicas formas de controle. Como resultado, duas reações eram comuns: (1) acomodação da maioria dos alunos; a aceitação ao comando da professora era bem aparente, e (2) resistência de outros que não agiam do modo que a professora preferia, mas ao invés disto desafiavam a autoridade dela.

A professora disse aos alunos e aos pais e responsáveis que as aulas de recuperação não iria ajudá-los a passar de ano, já que eles haviam tido todo o ano escolar para estudar. 
Estas aulas lhes dariam, porém, uma oportunidade de mostrarem que "eram melhores do que ela pensava". Os alunos deviam frequentar as aulas de recuperação sabendo que eram “casos perdidos”. Existem pelo menos duas explicações para os alunos concordarem em frequentar este tipo de aula. A primeira foi dada pelos professores: seus pais e responsáveis acreditavam que havia uma chance de seus filhos passarem e prosseguirem para o próximo ano, ou então - como apontou a diretora -, alguns alunos vinham para comer o almoço. Há uma forte crença entre os professores, diretora, supervisores e autoridades do governo de que a comida servida na escola é a motivação mais importante para as crianças frequentarem as aulas e para os pais as enviarem à escola. A análise deste fato não se sustenta ao sabermos que durante as férias escolares, a comida continua a ser servida, mas a frequência à escola cai consideravelmente ou é nenhuma em muitos dias.

Daqueles alunos a professora esperava passividade e acomodação às suas ordens. Na verdade, não importa o quão seja alienadora a tarefa proposta pela professora, a maioria dos alunos recebiam a instrução da professora passivamente.

Encontramos nas palavras de Andrade (1990) a sustentação para as evidências da argumentação aqui construída. De acordo com a autora;

A utilização de rituais, as práticas de repetição e memorização e a falta de consideração do nível cognitivo dos alunos parece servir para garantir uma forma a mais de controle e imposição do professor sobre os alunos. Ele serve também para inibir qualquer tipo de solução inteligente e criativa, premiando a repetição e a submissão (ANDRADE, 1990, p. 34).

Este exemplo forneceu uma perspectiva adicional sobre a interação em sala de aula, mostrou que a percepção das crianças e as suposições do grupo de pesquisa sobre as práticas de ensino não eram limitadas à sala de aula da Escola São Sebastião. O mesmo tipo de interação teve lugar em outra escola, em outro Estado, e foi observada por um grupo 
de pessoas completamente diferentes por Andrade (1986). Finalmente, o trabalho de Andrade (1986) mostrou que usando o método etnográfico, se pode revelar a subjetividade de certas questões, o que poderia ser mais difícil usando-se outra abordagem metodológica de pesquisa. 


\section{Referências}

ANDRADE, A. S. O cotidiano de uma escola pública de $1^{\circ} \mathrm{Grau:}$ um estudo etnográfico. São Paulo, Cadernos de Pesquisa $n^{0} 73$, p. 26-38, maio, 1990.

ANDRADE, A. S. Condições de vida, potencial cognitivo e escola: um estudo etnográfico sobre alunos repetentes da $1^{\mathrm{a}}$ série do $1^{\circ}$ Grau. São Paulo: USP, 1986.

BARRETO, E. S. S. Professores de periferia: soluções simples para problemas complexos. Cadernos de Pesquisa. $n^{0} 14$, p. 95-109, 1975.

BRANDÃO, Z. A. O estado da arte da pesquisa sobre evasão e repetência no ensino de $1^{\circ}$ Grau no Brasil (1971-1981). Rio de Janeiro: IUPRJ/INEP, vol. 2, 1982.

BRANDÃO, Z. A. Evasão e repetência no Brasil: a escola em questão. Rio de Janeiro: Dois Pontos, 1986.

BRANDÃO, Z. A. Índice de reprovação no $1^{\circ}$ grau é cada vez maior. Rio de janeiro, Jornal do Brasil, p.18, Maio, 1981.

BRASIL. Estatuto da criança e do adolescente. Lei no 8.069 de 13 de julho de 1990. Disponível em < http://www.planalto.gov.br/ ccivil_03/Leis/L8069.htm>. Acesso em 15 de janeiro de 2004.

MEDIANO, Z. D. et al. A percepção do professor de $1^{\mathrm{a}}$ a $4^{\mathrm{a}}$ série do $1^{\text {a }}$ Grau face ao aluno de baixo nível socioeconômico. Rio de Janeiro: PUC, 1983.

PATTO, M. H. S. Privação cultural e educação pré-primária. Rio de Janeiro: José Olimpo, 1973.

PATTO, M. H. S. A reprodução do fracasso escolar: histórias de submissão e rebeldia. São Paulo: T. A. Queiroz Editor, 1991. 



\section{O espaço da exclusão: o limite do corpo na sala de aula}

Carmen Lúcia Guimarães de Mattos

Neste capítulo são revisitados e apresentados os dados da pesquisa Fracasso escolar: imagens de explicações populares sobre dificuldades educacionais entre jovens de áreas rural e urbana do Estado do Rio de Janeiro (1992-1996). Os dados apresentados neste capítulo sintetizam as análises sobre o espaço físico de sala de aula como um dos determinantes da exclusão social de alunos no ensino fundamental. Teoriza sobre a interdependência entre o limite do corpo e a identidade social do aluno como membro do grupo constituído da sala de aula. Demonstra práticas de estigmatização de alunos e alunas e sua mobilidade física como instrumento de controle disciplinar e como critério avaliativo que determina seu sucesso ou fracasso ao final da série escolar.

Para demonstrar a afirmação de que o espaço físico delimita o corpo e marca a inclusão ou não do aluno no grupo de sala de aula procedemos ao mapeamento de várias classes de Ensino Fundamental, dentre elas apresentamos as análises da classe de $5^{\circ}$ ano de uma escola pública da cidade do Rio de Janeiro, cuja a professora foi colaboradora nesta pesquisa. Estavam presentes, no dia em que este mapeamento foi realizado, 24 alunos. A sala de aula da professora Rita mede $6 \mathrm{~m}^{2}$, as carteiras estão dispostas em grupos de quatro, o que não significa trabalho em grupo, pois os alunos, geralmente, trabalham de modo individual. 
Confrontamos o mapa físico de localização dos alunos com os seus resultados escolares, e encontramos uma estreita correlação entre estes dois fatores. Encontramos ainda, através de outros instrumentos: entrevistas, observação participante e registro de vídeo das aulas, que existe uma forma de distribuição física dos alunos em sala de aula que evidencia critérios discriminatórios de pertencimento ao grupo.

Segundo Bourdieu (1969):

Não há sociedade que não proponha, além dos modelos de conduta codificada ou não, modelos de conduta perfeita e exemplar, modelos que regem a maneira de executar os modelos, regras que regem a maneira de obedecer às regras ou de desobedecer-lhes: no jogo da excelência, o jogo com a regra sempre faz parte da regra do jogo (apud SIROTA, 1994).

É possível perceber pela fala da professora, abaixo citada, a distribuição dos alunos é feita a partir de critérios pouco claros para os mesmos, o que não os impede de descobrir, através de meios que lhes são acessíveis, alguns destes critérios.

...o Daniel que ficou com "D", que ele esse bimestre não quer nada, é brincadeira, sabe, faz parte do grupinho lá de trás da brincadeira (Daniel, aluno da turma).

\section{Diferenciação entre os grupos... ele é da patota do pessoal}

No interior da sala de aula evidenciou-se a existência de um tipo de "jogo" com o qual a professora de valorizava ou desvalorizava alguns alunos. O comportamento dos alunos passa a ser comparado, diferenciado, hierarquizado baseado em normas sutis. A classe, obviamente heterogênea, é classificada a partir de critérios homogeneizadores: os melhores, os piores, os que trabalham, os da bagunça, os do fundo da sala, os da patota. 
Os alunos participam ativamente desse jogo percebendo o seu enquadramento enquanto pertencendo a um determinado grupo. As formas de classificação e de diferenciação sutis são assim explicadas pela professora Rita:

... ele é muito desligado, ele é daquele que não quer nada. Ele é da patota do pessoal....

... a Joana é bitolada mesmo, coitada, desculpe o termo, é horrível o que eu vou usar, é emburrecida mesmo. Ela tem um, tem um problema, um bloqueio total, mas é demais de esforçada.

A avaliação caracteriza-se pela aplicação de normas internas reguladas pelas ações dos alunos formando conceitos sobre os mesmos que, por sua vez, classifica os grupos dentro de uma hierarquização de status do aluno, isto é, percebemos que o aluno que se senta nas primeiras fileiras recebem mais atenção por parte da professora do que o aluno que senta-se nas últimas, enquanto, os alunos que sentam-se ao fundo da sala não são cobrados quanto às execuções das tarefas. As normas sociais vigentes em cada sala de aula variam de acordo com o grupo e pela localização física de seus corpos, estando mais próximos ou mais afastados da mesa da professora.

O enquadramento do aluno em determinado grupo como sendo: “um determinado", passa a ser ratificado pela separação e remanejamento físico em sala de aula. Ou seja, o grupo de alunos considerados bons ficam sentado de um lado e o grupo de alunos considerados ruins ficam sentados do outro lado da sala de aula. 
Quadro 1 Espaço de sala de aula: inclusão e exclusão



Fonte: Filme da Sala de aula da Pesquisa: Fracasso escolar: imagens de explicações populares sobre dificuldades educacionais entre jovens de áreas rural e urbana do Estado do Rio de Janeiro -1992 a1996 (MATTOS,1996). 
Confirmamos os dados ilustrados pelo Quadro 1 através de entrevista com os alunos que afirmaram:

... tem um, dois lados. O lado da galera da bagunça e o lado da galera que fica quieto. É, fica a bagunça de um lado e do outro lado fica um monte de gente que tá fazendo o dever. (Ricardo $-5^{\circ}$ ano).

Segundo Keddie (1971) existe discordância entre as normas pedagógicas utilizadas por professores e sua prática cotidiana que mostram como os alunos são, muitas vezes, vítimas de percepções estereotipadas. Este processo é evidenciado quando dividem-se em grupos de níveis crianças e jovens de um mesmo grupo, ano escolar ou situação de aprendizagem. Esta divisão oferecem indícios para perceber as variações nos saberes transmitidos a esses diferentes grupos em função desses estereótipos.

A descrição desse processo permite compreender como as dificuldades educacionais e as identidades sociais de alunos são construídas. Estamos interessados em fenômenos que, no interior da sala de aula, criam e mantém as desigualdades sociais. Não se trata de descobrir o "por quê", mas o "como" são construídos estes estereótipos e quem eles servem.

Foi possível evidenciar pelo menos duas formas de avaliação responsáveis pela identificação de processos de marginalização e exclusão dos alunos tanto pelo professor quanto pelos próprios alunos. São elas: (1) o primeiro caracteriza-se pela forma diferenciada de comunicação que a professora mantém com os diferentes grupos. Exemplo: comunica-se mais ativamente com os alunos sentados à frente de forma instrutiva e com a voz regular. Comunica-se raramente com o grupo do fundo da sala com a voz alterada, quase sempre chamando a atenção do grupo sobre problemas de comportamento. (2) o segundo caracteriza-se pela forma com que os alunos identificam sua inclusão ou não no grupo de pertencimento que tem chance de obter aprovação tanto no ano escolar quanto no grupo de alunos e professores. Exemplo: ao ser promovido para o grupo da frente o aluno 
passa a comportar-se como um aluno com possibilidade de aprovação, ao ser enviado para o grupo do fundo da sala ele tem quase certeza da sua reprovação e passa a agir como pertencendo ao grupo da bagunça.

Esta forma de avaliação parece fazer parte da rotina das escolas de um modo geral. Segundo Ribeiro (1993) existe algo de profundamente errado no sistema público de educação que faz com que os estudantes passem dias e anos em instituições que lhes dão muito pouco e terminam, em muitos casos, por estigmatizá-los pelo fracasso e repetência. Dessa forma, a escola constitui-se num sistema de classificação dos indivíduos que contribui para manter as desigualdades sociais fora dela.

\section{A sala de aula da professora Rita: ... ela ignora os outros meninos que não são bons alunos.}

Em entrevista com a professora Rita foi evidenciado que, no contexto da sala de aula existem pelo menos dois tipos de alunos que recebem a atenção da professora de formas distintas. O primeiro, o grupo “dos melhores” é a minoria, pois são os alunos que não estão defasados na série ou têm uma defasagem pequena. O segundo, é o grupo dos “alunos piores” onde se incluem aqueles com maior defasagem em relação a série. Enquanto que o primeiro grupo recebe atenção e disponibilidade da professora, o segundo não recebe esta mesma atenção por parte da mesma que, não raro, estabelece uma relação de falta de credibilidade quanto ao sucesso dos alunos, garantindo que estes são aqueles que não "merecem ser trabalhados, pois não renderão muita coisa no final do ano”.

Observou-se quanto a localização dos grupos na sala de aula que dentre os 24 alunos que estavam na sala neste dia, 4 faziam parte do grupo considerado pelos alunos como a turma da bagunça e pela professora como o grupo dos piores.

Acreditamos que a localização física preferencialmente adotada pelo grupo dos alunos bons coincide com a preferencia da professora pois dele resultou o maior número de 
aprovação no final do ano. O contrário, vale para o comportamento do segundo grupo, como pode ser observado pela fala dos alunos:

Ela só dá esporro. É, ela não xinga, ela fala pro bem da gente. Ela fala assim: se você não faz isso ô viadinho, eu vou te dar porrada. Se você não se comportar (...) eu vou mandar os garotos te linchar. Te dar muita porrada pra tu aprender. Ela fala de brincadeira, mas a porrada é de verdade (Rogério e Leonardo, falando alternadamente $-5^{\circ}$ ano).

Durante o ano, aos alunos do grupo considerado ruim são dadas algumas chances para mudarem sua localização passando para o grupo dos bons, no entanto, a chance é sempre retirada dependendo da avaliação da professora e dos demais alunos. Neste caso, o aluno e a professora consideram que este aluno não aproveitou a oportunidade ou a chance que lhe foi dada para mudar de status no grupo. Como nos explica os alunos abaixo:

... aí eu ficava naquele lado, aí a dona Rita me deu uma chance e me botou no lado da galera que fica quieto, aí eu perdi a chance e voltei pra lá de novo.

Porque ela sabe, ela sempre fala pra mim: você é inteligente, o negócio é que você faz muita bagunça, eu te boto pra voltar lá de novo. É assim que ela fala. Ela tipo me deu uma chance (Renato $-5^{\circ}$ ano).

Não "aproveitando" a "chance” que lhe foi dada o aluno retorna para o seu grupo de origem, que provavelmente receberá menos atenção, informação e credibilidade de professora.

Só lá pro final, começa a querer melhorar só que não dá mais tempo, já não vai passar mais. Aí acabou (Reginaldo $-5^{\circ}$ ano). 
Incluído no contexto de sala de aula sem, no entanto, gozar do status de "membro do grupo de alunos", o aluno considerado desinteressado, bagunceiro e agitado, ou que se senta nas últimas fileiras de carteiras, procura entender e identificar os critérios que avaliam a sua identidade como aluno, quais destes interferem na sua passagem à categoria de "aluno membro do grupo" e, os macetes para usufruir uma posição privilegiada dentro da sala de aula, assim como os demais alunos. Como ratifica a citação abaixo:

Na sala de aula não se trata unicamente de transmitir ou ensinar saberes, trata-se sobretudo de "fazer frente" a situação aprendendo os macetes, os truques do ofício, a descobrir como se virar, a descobrir as hierarquias, os temas apropriados de conversa, os tabus... (SIROTA, 1994).

Acreditamos que os alunos pertencentes ao grupo dos "piores", da "bagunça", dos "ruins" são críticos de sua condição dentro de sala de aula e da importância que a sua localização física representa para a sua aprovação ou reprovação. No depoimento do aluno abaixo, sobre o momento em que este já sabe que vai ser reprovado, podemos perceber claramente esta percepção:

Quando a professora já começa, porque tem um, dois lados. O lado da galera da bagunça e o lado da galera que fica quieto. [...] Fica na mesa assim, é tudo... é a mesa. Só que tem um lado que fica a galera da bagunça, é a galera [...]. Não, ela não separa não. Tá cheio de mesa vem e sentam no lado que é da bagunça. [...] Quando ela começa já... por exemplo, eu tô na ala do silêncio, aí ela já me começa a fazer... bota na bagunça, já é uma prova que eu não vou passar mais (Vinícius, $5^{\circ}$ ano).

Os exemplos do Quadro 2 e 3 abaixo, vivificam as imagens dos espaços de sala de aula, em outro dia de observação diferente do demonstrado no Quadro 1 anteriormente apresentado, 
e ilustra mais uma vez como a localização dos alunos, mais próximos e mais distantes da professora era marcado na sala de aula e implicava numa separação territorial de pertencimento em sala de aula e no grupo daqueles que recebiam mais atenção da professora que estavam engajados na tarefa e que no caso desta classe receberam conceitos melhores e passaram de série:

\section{Quadro 1}

Espaço de sala de aula: exclusão por afastamento da professora



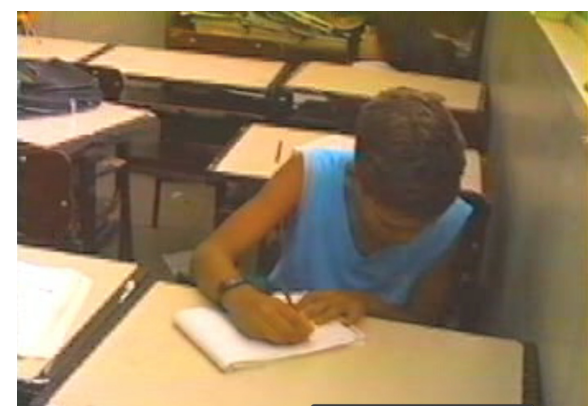

Fonte: Filme da Sala de aula da Pesquisa: Fracasso escolar: imagens de explicações populares sobre dificuldades educacionais entre jovens de áreas rural e urbana do Estado do Rio de Janeiro -1992 a1996 (MATTOS,1996)

\section{Quadro 3}

Espaço de sala de aula: inclusão por aproximação da professora

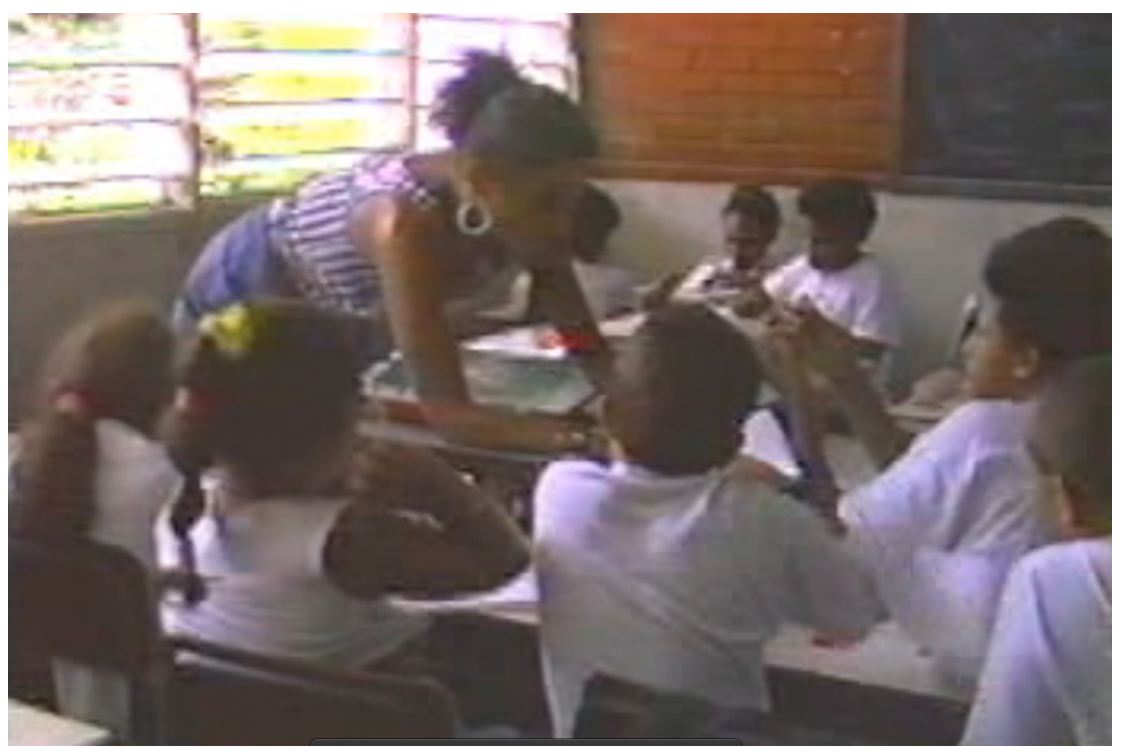

Fonte: Filme da Sala de aula da Pesquisa: Fracasso escolar: imagens de explicações populares sobre dificuldades educacionais entre jovens de áreas rural e urbana do Estado do Rio de Janeiro -1992 a1996 (MATTOS,1996) 
Dos 24 alunos presentes a sala de aula da professora Rita, os quatro que estavam sentados na "ala da bagunça” foram reprovados sendo que um foi "convidado" pela professora a não vir mais à escola a partir dos meses de novembro do ano letivo (em que a pesquisa foi realizada).

A dona Rita falou com a diretora que não quer ver a cara dele [do aluno] nem pintada aqui no colégio. Ela avisou que ele não ia passar de ano. Então não precisava vir mais.

Pesquisas de Ribeiro (1993) demonstram que as estatísticas oficiais não incluem a "repetência branca" que compreende aqueles alunos que foram "aconselhados” a não se submeterem às avaliações do final do ano para evitar a reprovação, já decidida à priori pelos professores. Esses são convidados a retornar no ano seguinte. Esta estratégia não apenas encobre a repetência sob o véu da atribuição de responsabilidade ao aluno por não permanecer na escola. Entretanto, permanecer implica em vivenciar no espaço da sala de aula regras que mudam o tempo todo na dinâmica das interações entre a professora e os alunos na sala de aula.

\section{Considerações finais}

O espaço da exclusão na sala de aula ofereceu indícios para pensar o modo como foi retirado dos alunos a possibilidade de superação de suas dificuldades educacionais. Promoveu um tipo de homogeneização que pode ser considerada como perversa se entendemos que a escola é o espaço de integração, de respeito às diferenças, de oferecer uma educação de qualidade, dentre outras funções. Ao aluno considerado como bom ou mau em função do comportamento não é oferecida a possibilidade de obter uma avaliação objetiva e clara quanto a suas aprendizagens em sala de aula. Aos alunos excluídos ao longo do ano letivo resta receber o resultado, ao final do ano, de uma avaliação equivocada quanto ao que se refere aos processos educacionais uma vez que já é amplamente conhecido pelos professores, gestores e os próprios alunos que eles 
não possuem a chance de serem aprovados. Ressalta-se que os mesmos permanecem ainda que em condições que não podem ser revertidas.

Bourdieu (1998) menciona o assunto explicando sobre os excluídos do interior. Esse processo a que a escola expõe seus alunos baseada em uma perspectiva de inclusão educacional na prática não se efetiva.

Os alunos vivenciam criticamente as configurações da sala de aula para informar sobre os que são bagunceiros, piores, ruins. Entendem que estar do lado "certo" da sala de aula poderá promove-los às etapas seguintes da escolarização. Entretanto, coexiste no espaço da sala de aula a necessidade de pertencer ao grupo de amigos, implicando em seguir as regras deste e o de pertencer no espaço do inclusão nomeado pela professora com outras regras. Cabe aos alunos decidirem, pois como explicou Vinícius que se ele for para o outro lado encerram-se suas chances de ser aprovado, ou seja, de passar para o outro lado.

Aprender sob a esfera da impossibilidade, do medo e da falta de clareza quanto aos objetivos do processo educacional torna a vida escolar do aluno um jogo de negociações diárias no qual a dinâmica se altera de acordo com o momento da interação entre a professora e os alunos. Resta questionar como é possível estabelecer um processo avaliativo que possa promover as aprendizagens dos alunos e não perpetuar espaços de exclusão em sala de aula inviabilizando a redução das desigualdades socioeducacionais deixando de ser a terra prometida que se afasta no horizonte. 


\section{Referências}

RIBEIRO, S. C. A educação e a inserção do Brasil na modernidade. Cadernos de Pesquisa, São Paulo, Fundação Carlos Chagas, $\mathrm{n}^{\circ}$ 84, p. 63-82, 1993.

SPRADLEY, J. P. Participant observation. New York: Holt, Rinehart and Winston, 1980.

KEDDIE, N. Classroom Knowledge. In: Young M. Knowledge and Control. London: Collier \& Mac Millan, 1971.

SIROTA, R. A escola primária no cotidiano. Porto Alegre: Artes Médicas, 1994. 



\section{Uma análise etnográfica das dificuldades educacionais de alunos e alunas e do (des) controle de professores e professoras: $\boldsymbol{c}$ mais $\boldsymbol{d}$ o que dá?}

Carmen Lúcia Guimarães de Mattos Paula Almeida de Castro

O texto se dedica a descrever a função de controle exercida pelo professor, através da nota, do julgamento que faz de seus alunos. Construído a partir de dados de três pesquisas etnográficas: Picturing school failure: a study of diversity in explanations of educational difficulties of difficulties among rural and urban youth in Brazil (1992), Fracasso escolar: imagens de explicações populares sobre dificuldades educacionais entre jovens de áreas rural e urbana do Estado do Rio de Janeiro (1992-1996), Metacognição em sala de aula: um estudo sobre os processos de construção do conhecimento na perspectiva do jovem infrator no Estado do Rio de Janeiro (1997-1999). Descreve cenas retiradas de observações de sala de aula, de interações entre a professora e os alunos, conselhos de classe e entrevistas com alunos, jovens e professores. As imagens de sala de aula foram destacadas sob a forma de eventos, situações e cenas permitindo uma significação e explicação das medidas de controle impostas aos alunos em risco escolar. Dois aspectos do processo de controle exercido pelo professor foram estudados, a primeiro discute o controle pela nota, levantando, por um lado, aspectos sobre a coerção, a chantagem e a manipulação do professor, e por outro, a compreensão pelo aluno de que ele necessita da nota para passar de série, e que muitas vezes, não sabe como obter essa 
nota. O segundo aspecto do controle analisado discute as formas pelas quais os julgamentos que os professores produzem sobre os seus alunos interferem no resultado acadêmico obtido por eles.

\section{O controle pela nota - pode o professor avaliar o seu aluno mais pelo comportamento (disciplina) do que pelo rendimento escolar?}

No contexto da pesquisa etnográfica sobre o fracasso escolar realizada por Mattos (1992-1996) um dos temas que suscitou nossa curiosidade foi a preocupação das professoras em adequar as tarefas acadêmicas à realidade do aluno. Observamos duas classes por dois anos consecutivos e ainda assim, não conseguimos descrever o entendimento que alunos e professoras tinham sobre essa realidade. Pensamos em explorar o assunto através de um questionário diagnóstico dessa realidade a ser respondido pelos alunos, pais e professores. Embora estivéssemos trabalhando em colaboração com a professora da classe estudada, não conseguimos seu consentimento para proceder a coleta dessas informações por questionários, cujo conteúdo foi julgado inapropriado por conter perguntas sobre sexualidade e uso de drogas. Junto com a professora pensamos numa solução para o impasse e por sugestão da mesma propusemos que os alunos fizessem uma redação com o tema: o que é a realidade para você. Dentre os resultados obtidos destacamos esta imagem desenhada pelo aluno que nos auxilia a pensar sobre a proposta deste texto. O controle pela nota. 




Desenho do aluno do $5^{\circ}$ ano.

Fonte: Pesquisa Fracasso Escolar (1992-1996).

O exercício retratado pelo aluno sugere que a proposta da professora é a solução de uma expressão matemática de impossível solução, contendo elementos contraditórios e organizados de forma desconexa. Enquanto os alunos, representado proporcionalmente em tamanho reduzido em relação a representação feita da professora assistem a explicação atentos. No quadro ao lado o aluno recebe o boletim de notas onde o conceito D é justificado verbalmente pela professora como resultado da falta de atenção à aula. O D do boletim toma quase todo o tamanho do papel, de forma expressiva, correspondendo, ainda, ao tamanho do dorso do menino que o recebe.

A forma de atribuição de notas através de conceitos expressos em letras não diminui a insegurança e ansiedade dos professores e dos alunos e alunas em relação à nota. A substituição de números por conceitos produz um efeito de falsa justiça. Sob a ótica do professor, atribuir um conceito $\mathrm{E}$ significa que o aluno não participou em nenhuma atividade de ensino, enquanto atribuir a nota 0 significa que o aluno não conseguiu completar nenhuma das tarefas que valiam para a nota. No limiar do fracasso, o aluno pode merecer um D ou um C, mas não merece um E, enquanto uma nota 5, 3 ou 0 são medidas exatas que sugerem reprovação, são notas no 
vermelho. Nossa interpretação da percepção dos professores sobre a atribuição de notas e conceito sugere que eles ainda confundem "medir” com "avaliar” o que faz com que fiquem com impressão de terem sido imparciais. Este fato foi evidenciado não só em nossas pesquisas, mas em outros trabalhos sobre o mesmo tema.

Um artigo sobre a avaliação significativa de Bordoni (2004) confirma essa interpretação:

\begin{abstract}
"Avaliar não significa necessariamente medir e nem o referencial quantitativo significa necessariamente objetividade. A prática de uma educação positivista deixou-nos esse ranço. Aliás, quando tentamos traduzir em números ou "conceitos" frios o que é incomensurável, as aberrações são evidentes. Que tipo de avaliação tem um aluno que "tirou" 5 ou C? Significa "suficiente", mas suficiente para que? O que ele não sabe, não vai fazer falta? Por que não sabe? A avaliação "medida” mais esconde do que mostra. E não adianta transformar nota em conceito, pois o que tem que mudar é o objeto da avaliação" (BORDONI, 2004).
\end{abstract}

Podemos também derivar da afirmação da autora que a avaliação continua sendo um fenômeno pouco entendido pelo professor como instrumento de ensino e aprendizagem, como nos afirma Hoffmann, indica em seus estudos sobre como os professores percebem a avaliação como um fenômeno indefinido, usam o termo e atribuindo-lhe diferentes significados, relacionados às práticas avaliativas tradicionais: prova, nota, conceito, boletim, recuperação, reprovação (HOFFMANN, 1993, p.14). O fato da avaliação se traduzir num resultado concreto para o aluno e seus pais ou responsáveis, faz com que, muitas vezes, seja utilizada pelo professor com o objetivo não só de medir seu rendimento, mas também de promover mudanças no aluno - corrigir desvios de comportamento, por exemplo. $\mathrm{O}$ aluno que resiste a esse controle é aconselhado a agir de acordo com as normas ou será punido, tanto com a nota, quanto com a reprovação. $\mathrm{O}$ aluno resiste a estas normas e a própria prática 
avaliativa. Essa resistência do aluno se manifesta de diversas formas em situações de sala de aula e é comumente explicitada através da indisciplina.

A supervalorização da nota está intimamente ligada à relação assimétrica de poder entre o professor e os alunos (ERICKSON, 1986). O professor tem dificuldade para lidar com pequenos grupos indisciplinados em sala de aula. Não sabem lidar com as lideranças negativas. O conteúdo e a nota são usados como instrumento de normatização, isto é, para ameaçar o aluno indisciplinado.

Nas falas que se seguem destacamos algumas situações em que o conceito, a avaliação e a nota se confundem com a percepção negativa sobre o comportamento do aluno.

"Aqueles alunos e alunas que não fazem nada ficam prejudicando a turma e os alunos e alunas que ficam atrapalhando a gente, eles atrapalham e a gente não tem o que fazer [...] Inclusive...no segundo bimestre vieram dois alunos e alunas né! e um deles é aquele que agita...pra turma ficar assim... aquele moreninho, ele inventa as brincadeiras, sabe? Uma brincadeira horrorosa, ridícula!" (Rosangela, professora do $2^{\circ}$ ano do Ensino Fundamental).

“...ficou com D que ele esse bimestre não quer nada. É brincadeira, sabe? Faz parte do grupinho lá de trás da brincadeira, mas ele se prejudica porque tem aluno no grupinho que apesar de brincar, se esforça, mas ele não...teria que ter um D mesmo, tá?” (Janaína - Orientadora Pedagógica).

"Esses dois não, não tem, não vão fazer mesmo, debocham da minha cara [...] na hora de você fazer a avaliação deles cê tem que fazer a avaliação deles pelo conteúdo mínimo que está por série...Por que sete, dez vão ser reprovados, sacô? Podem chamar o DEC eu não posso fazer milagres, tá entendendo? Eu tenho consciência de meu trabalho porque 
isso eu tenho, por enquanto, ainda tenho, sabe?" (Rita, professora do $5^{\circ}$ ano).

“...esses alunos e alunas que não estudaram, não conseguiram convencer durante esses seis anos que eu vim pra turma do Vinícius, agora...eu tinha quatro com $B$, acho que é quatro, né?" (Lúcia, professora do $3^{\circ}$ ano).

“...Porque ela não faz, porque não estuda? Não sabe dizer. E ela ficou com D” (Tânia, professora do $2^{\circ}$ ano).

“...esse pessoal de $\mathrm{C}$ mesmo, tem que cobrar, né/,,,pro João eu dei B pra ele... Porque eu não me sinto apta a dar uma nota baixa pra um aluno que sabe redigir, quer dizer, teve idéias em redação...” (Rita, professora do $4^{\circ}$ ano).

"A Mariana, ela melhorou no comportamento e tudo, mas ela não escreve nada.” (Joana) “...ela tá bem melhor em comportamento, ela não agride mais, ela aceita, ela leva, ela continua levando bronca e tal, mas ela aceita...”(Marivalda, professora do $5^{\circ}$ ano).

"Ela tá com C por comportamento que ele tá se achando o máximo [...] Eu digo que te dou $\mathrm{B}$, você quer o $\mathrm{B}$ ? Mas vai ter que jurar pra mim que vai ficar quieto" (Rita, professora do $4^{\circ}$ ano).

Fonte: Pesquisa Fracasso Escolar (1992-1996).

Através dos depoimentos dos professores percebemos que a nota é atribuída ao aluno não pelo o que ele aprendeu, mas pelo seu esforço em aprender e pelo comportamento que apresenta em sala.

Essas professoras acreditam que o fracasso está associado a uma característica pessoal do aluno - a ignorância. Herdada do interior da classe social a que pertence, a ignorância, acreditam eles, é resultado de pais não alfabetizados que geram crianças pouco favorecidas intelectualmente. Essa visão este- 
reotipada é reforçada por inúmeros estudos sobre o fracasso escolar, como na citação abaixo:

Quando a criança atinge o estágio das aprendizagens formais, já existe nela toda uma estrutura de conhecimento que reflete a cultura de sua família e de seu meio cultural. E nem sempre essa cultura é compatível com a da escola. Daí surgem, frequentemente, os primeiros obstáculos ao ato de aprender, em consequência desses choques culturais (MAMEDE, 1993).

Esta assertiva tem suas raízes não só nas relações assimétricas de poder geradas no interior das relações escolares, mas na origem da concepção de justiça que permeia estas relações. Rawls em seus estudos sobre a justiça, ao analisar o valor da ignorância, explica que a ignorância quando associada à noção de ingenuidade pode parecer um sinônimo de bondade e de pureza. Alguém é puro e bom na sua ignorância, ao contrário, alguém é mau e ardiloso quando considerado sábio, ágil e inteligente (RAWLS, 1997, p. 169). Neste sentido o fato de ser ignorante é duplamente justificado, pela origem sócio-familiar e pela ingenuidade individual. Esta percepção pelos professores desloca a responsabilidade dos mesmos para bem longe dos conteúdos e da sala de aula. Considerados ingênuos, os alunos não conseguem distinguir as regras que devem seguir para pertencer ao grupo social, mas valorizam a escola.

Embora ciente deste mecanismo desigual e injusto o professor/a lida com essa rotina, submete o seu aluno ao fracasso, ameaça com a exclusão, mas nem por isso fica livre do sentimento de inadequação e injustiça. No cenário apresentado sobre o controle pela nota, muito podemos nos espelhar em nossa rotina diária. As trocas simbólicas que promovemos estão diretamente relacionadas ao nível de envolvimento em termos de poder e de aceitação desse poder pelo outro. A posição de desvantagem do aluno no cenário recria a resistência, muitas vezes silenciosa. Entretanto, a quebra da resistência está associada a mecanismos assimétricos desta relação e não permite ao aluno uma saída, colocando-o na zona de risco educacional. 
Concordamos com Connell quando fala sobre as crenças institucionais sobre a incapacidade dos alunos como condição primordial para a criança prosseguir seus estudos além de um determinado nível. Segundo ele:

(...) as escolas geram imagens distorcidas delas próprias, e de sua clientela, que são condensadas num conceito específico: capacidade. Em sua forma mais popular é a noção de miolos. Se uma pessoa tiver miolos (capacidade), irá bem na escola; se não tiver não irá (CONNELL; et al. 1982).

O autor explica que para entender o sucesso ou fracasso acadêmico precisamos nos apropriar de dados sobre as práticas de sala de aula. Para entender o fracasso acadêmico é importante entender as dificuldades que os professores encontram para elaborar de tais práticas. O que significa que explicar o fracasso a partir do controle pela nota é focar apenas um dos aspectos da questão da avaliação.

\section{Controle pelo julgamento - pode o professor avaliar segundo o entendimento que ele tem sobre as dificuldades (deficiência psicofisiológica) dos seus alunos?}

Ann Bastian e seus colegas realizaram nos anos 80 um estudo sobre as escolhas que as escolas públicas fazem em relação a seus objetivos, identificados pelos autores como elitistas ou democráticos. Esta escolha é originária da polarização entre o atendimento as características de igualdade e de excelência. Pressupõe que a igualdade na escola é um direito inalienável, que a escola pública pertence ao cidadão, não como cliente dela mas como seu proprietário. Para atingir a excelência e igualdade a participação de seus membros no processo educacional é fundamental, assim como múltiplos níveis de mudanças estruturais serão exigidos no interior das escolas (BASTIAN, 1986, p. 5). 
O estudo de Mattos (1992) descreve cenas que ilustram as escolhas que os professores fazem e, através das quais podem materializar os desejos de uma educação elitista ou deslocada de seu contexto.

A sala de aula de recuperação final de uma $1^{\circ}$ ano do Ensino Fundamental de uma escola Rural foi observada a interação entre a professora e seus alunos. A professora Leonora interagia com os alunos e alunas individualmente, dando a impressão de que ela estava interessada em cada um deles. Chamava cada um pelo nome, sabia onde cada um sentava e que tarefa cada um realizava. Entretanto, ela nos dava a impressão que sua familiaridade com os alunos era um meio de controle; para reforçar a disciplina e manter as crianças trabalhando. Ela usava comentários ameaçadores, “... Isto é para nota! ... Você não vai sair para o intervalo Rogério! ... Olhem para a frente ! Eu vou dar nota nisto, certo ? A ameaça era associada a outros tipos de interações negativas. Agressão verbal (gritar com os alunos e alunas) e agressão física (bater nas cabeças, mãos e carteiras dos alunos e alunas). Ao insistir nesta abordagem para manter a disciplina ela demonstrava estar confusa em relação a eficácia da mesma. Pois, não funcionava. Os alunos e alunas continuavam a saírem de suas carteiras, não realizando a tarefa, a maior parte do tempo. Eles conversavam uns com o outros, às vezes falavam alto que não realizariam a tarefa pedida por Leonora. Uma menina com cerca de 8 anos disse: “...Isto não [..] Eu não vou copiar isto ! Outros alunos não diziam nada mas não faziam nenhum trabalho também. A maioria dos alunos parecia estar trabalhando de algum modo. A professora continuava a lembrar que o exercício ia ser para nota.

Dentre alguns aspectos que caracterizavam a relação professora/alunos eram: uma supervalorização da disciplina, do conteúdo, e da nota, em detrimento a aprendizagem do aluno e da aluna. Como reação notava-se a resistência dos alunos.

Ronaldo, um aluno 12 anos, repetente 3 vezes, é um caso de resistência ao trabalho proposto pela professora. Ele trabalhou algum tempo na tarefa, mas ficou quieto a maior parte do tempo, sem fazer nada. Embora a professora se dirigisse a 
ele de uma maneira negativa 11 vezes durante o período de observação (40 minutos) ele não demonstrou nenhuma reação a ela. Ele continuou como se estivesse trabalhando por segundos enquanto a professora passava por perto. Ele parava de trabalhar quando ela saía. A professora considerou este tipo de comportamento como falta de motivação e acomodação, considerando este um comportamento típico de um menino de zona rural que não aprende por falta de interesse e pouca frequência às aulas, ela falou para o menino:

\begin{abstract}
Ronaldo, continue! [..] continue (quase gritando com ele porque ele não estava trabalhando). ... Está tudo errado ! [..] (olhando para o caderno dele). ... Não é 25 , é 2 por 2 [..] Está tudo errado! Tudo! [..] Agora você pulou o [..] Todos aprenderam menos você, Zacarias ! [..] 4, depois vem 5, [..] , 6, [..] Você tem que contar de 2 em 2 Ronaldo! Qual é o 5 ?...Qual é este número Ronaldo? [...] Depois de contar [..] conte [..] 3,4,5,6, (ela continuou a falar). Ronaldo! Quem mandou você faltar às aulas, você faltou o tempo todo.
\end{abstract}

Fonte: Picturing school failure (1992).

Tanto nas escolhas que o professor faz dos seus objetivos quanto na sua abordagem ou estratégia de ensino o professor e aluno demonstram estarem em diferentes níveis de compreensão do que está sendo proposto como ensino-aprendizagem, isso se traduz de modo mais claro na linguagem, quase sempre descontextualizada que representa a imagem de uma contradição cultural.

Sobre este aspecto a socióloga Sirota (1984), em seu estudo sobre a sala de aula, analisa que na interação face a face existe um jogo de valorização do discurso que se caracteriza por duas redes de comunicação. A autora parte da hipótese de que no interior do jogo da igualdade formal entre os alunos e alunas face ao professor, os discursos do professor e seu comportamento não produzem ou reproduzem um arbitrário cultural ou uma norma, as normas são construídas a partir de cada um. Para ela esse processo parece ter como base um mecanismo de 
valorização ou desvalorização do discurso e dos comportamentos dos alunos, comparados, diferenciados e hierarquizados, em relação a essa norma implícita e subjacente ao funcionamento da sala de aula. Neste esquema, o jogo é vivenciado indistintamente por toda a turma. A rede de comunicação principal se refere apenas a uma parte da turma, na qual alguns alunos são efetivamente sujeitos de uma comunicação - são interessados, valorizados e têm o que dizer, visto que a situação de aprendizagem faz sentido para eles. Enquanto na rede de comunicação paralela onde se situa a outra parte dos alunos na sala de aula, os mesmos estão em posição externa à rede principal de comunicação - não estão interessados, nem são valorizados, nem são parte integrante, desenvolvendo portanto condutas de ilegalidade escolar ou apatia (SIROTA, 1984, p. 37).

A partir das ilustrações abaixo a professora pediu aos alunos que fizessem um trabalho sobre a família, sua importância e seu papel para eles. Apresentou como sugestão a família tradicionalmente representada abaixo no desenho colorido à esquerda, o aluno, ao realizar a tarefa representou a família como no desenho em preto e branco à direita.

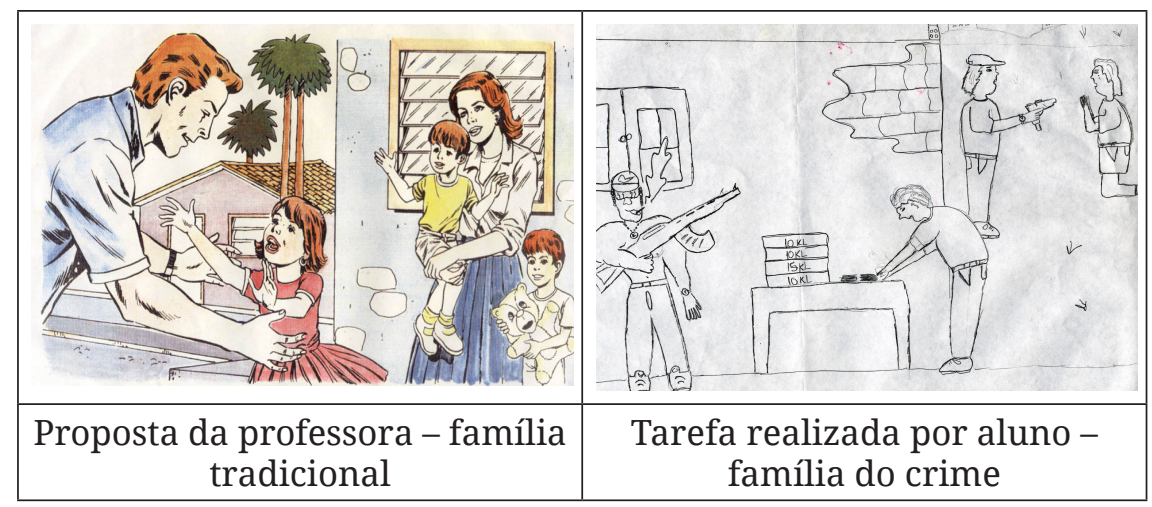

Fonte: Metacognição em sala de aula (1997-1999).

A resistência expressa ao trabalho proposto denuncia o confronto cultural e falta de propósito do trabalho para o aluno, evidenciando ainda a rebeldia contextualizada pelo mesmo. 
Esta discrepância cultural nos oferece o pano de fundo para interpretar a forma como algumas escolas lidam com a diferença cultural. Dispostos a promover mudanças no aluno a escola deposita neles o ônus da inadequação, buscando uma razão e uma solução para o problema. Nessa busca encontra um repertório de razões psicofisiológicas que podem afetar a capacidade do aluno e da aluna e o encaminhamento para especialistas como uma solução imediata. Esta estratégia tem sido utilizada - muitas vezes, sem sucesso, pois os alunos e alunas, por razões socioeconômicas não conseguem o atendimento - e acarretam um sentimento de inadequação e baixa alta estima entre os alunos e alunas, não raro levando-os a exclusão educacional.

Como podemos visualizar pelas falas das professoras e gestores durante o Conselho de Classe (MATTOS, 1992-1996) a medicalização e o encaminhamento é muito comum nas escolas.

A Alessandra, você se lembra que nós chegamos a encaminhar a Alessandra, inclusive ela tem um irmão com problema sério, tá?” (Cristina, coordenadora) “...não foi a fono? Que a gente colocou as crianças que tinham dificuldade, mas que trocavam as letras! [...] "O problema dela, eu acho que se ela tratar no psicólogo, ela consegue.” (Luciana, professora, $2^{\circ}$ ano).

"De repente, ele emenda tudo, agora quando ele tá calmo, ele faz tudo certinho, quer dizer, na época que ele fazia NOAP ele melhorou bastante" (Sônia, professora, $2^{\circ}$ ano)

"Que ela chega assim, não sei fazer nada mesmo, não vou fazer, é tipo assim, né? Então eu já fiz uns dois exames com ela. Eu fui muito legal pra ela, eu tentei paparicar e consegui alguma coisa. Aí eu tentei ser radical também, aí eu vi que não conseguia nada com ela. Aí eu tentei maneirar, entendeu. Mostrava as condições pra ela, tipo uma chantagem, você não vai ao recreio, você não vai pra lugar nenhum, entendeu? Aí ela começou: - Tia, tá 
certo? - Eu consegui. Então é aquele tipo de pessoa que você atende a todo momento, isso é impossível a gente fazer isso... [...]...Eu acho ela uma pessoa esperta, capaz, ela acerta rápido, agora o negócio é ela querer... [...]...0 problema dela, eu acho que se ela tratar no psicólogo, ela consegue.”(Luciana)

"A Cléria é outra. A Cléria é super inteligente e sabe tabuada na ponta da língua, tudo o que eu perguntava ela respondia...tia, você não acredita que eu estudei? Eu acho que era verdade, porque eu realmente não achei nada e ela respondia tudo... [...]... Eu acho que a dificuldade dela é só psicológica. Tanta dificuldade, né?” (Dora)

“...existem alguns alunos que realmente merecem uma avaliação é, de alguns profissionais que entendem mais.

Fonte: Fracasso escolar (1992-1996).

Nas falas acima a professora Sônia menciona que a aluna melhorou na época em que fazia NOAP (Núcleo de Orientação e Atendimento Psicopedagógico) vinculado ao Departamento de Educação da Pontifícia Universidade Católica do Rio de Janeiro com atendimento de especialistas em problemas relacionados à aprendizagem. As professoras da escola onde a pesquisa foi realizada comumente encaminhavam alunos para terem acompanhamento psicopedagógico no NOAP. Além do tipo de atendimento oferecido pelo NOAP as professoras lançam mão de outras áreas como a fonoaudiologia e psicologia.

Existe uma tendência entre os professores em atribuir o problema do fracasso dos alunos a eles próprios, em detrimento de outros fatores externos a eles foi conceituado por pesquisadores como a teoria da culpa da vítima (JOHNSON, 1981; RYAN, 1981; FINE, 1981). A crítica pelos professores aos alunos evidencia que eles culpam esses jovens pelas incapacidades e inadequações. Os objetivos escolares baseados em características pouco relevantes para os alunos, assim como as práticas pedagógicas baseadas em conteúdos simplistas e alienadores no contexto analisado não foram considerados por esses professores. 


\section{0 controle pela informação escrita: podem os professores controlarem seus alunos através de informações escolares, tais como arquivos, relatório, fichas, diagnóstico médico, histórico escolar e dados de matrícula?}

As informações escritas arquivadas pela escola, muitas vezes são usadas por professores para justificar os problemas que eles apresentam em sala de aula. O uso dessas fichas pelos professores foi interpretado por eles como tendo dupla função: oferecer subsídios para diagnósticos sobre as falhas de aprendizagem que os alunos apresentam e preparar os professores para receberem os mesmos.

Na escola analisada neste capítulo, dois alunos recém chegados por transferência de uma escola próxima, justificaram sua "inclusão" numa série inferior a que freqüentavam na escola de origem pelo conteúdo que não foi oferecido a eles nessa escola. Conteúdo esse que é baseado no mínimo previsto para a série e que raramente é de conhecimento do aluno. Portanto, a fala dos alunos pode ser interpretada como a imagem passada a eles pela escola receptora. Eles disseram:

“...é assim oh! Cê está no terceiro ano, passa pro segundo, cê está no segundo, passa pro primeiro. Ao ser perguntado como isto pode acontecer , ele explica: Bem, a diretora pede a ficha, e você... [..] É assim, por exemplo, como nós... cê está no terceiro ano lá, vamo fica no segundo aqui... A escola lá é ruim, é o que a diretora disse... [...] aqui o primeiro ano é real" (fala de um aluno do $3^{\circ}$ ano recém transferido de uma escola da vizinhança e matriculado nesta escola no $2^{\circ}$ ano).

As falas das professoras sobre a prática do rebaixamento ratificam essa interpretação:

"Ela repetiu a $1^{\mathrm{a}}$ do livro, repetiu a $2^{\mathrm{a}}$ do livro, mas não sabia nada, né? Então ela entrou primeiro como se estivesse fazendo um trabalho de pré, CA, tudo...aí todo mundo foi 
arrastando, deu pra pegar a $2^{\mathrm{a}}$, mas na $2^{\mathrm{a}}$ série começou atropelando...” (Tânia)

"Eu pedi, ta lá nas pastas, pois é, no momento que houver necessidade é só ir lá e pegar...” (Cristina)

"Nós temos professor aqui que faz individualmente. Por exemplo, a Lúcia, bimestralmente ela faz dos alunos, das características, se cresceu..[..]Tem que ter boletim... Boletim é aquela folha branca? (referindo-se a ficha branca que a secretaria arquiva) "(Glória).

“...quando existe esse, algum relatório, de algum tratamento, de algum aluno, de alguma observação, ele tem o cuidado de colocar na pasta do aluno, porque é um dado importante...” (Beth)

"A gente podia fazer o seguinte então. No primeiro dia você mandaria um relatório." (Cristina) “...falaram lá sobre avaliação que todo ano, né? Todo final de ano a professora faz o relatório, isso foi dito que é normal em todas as escolas, sabe? Então disseram que se faz o relatório a respeito dos alunos daqueles que a professora passou, mas por exemplo tem problemas, então, sabe?” (Beth)

Entretanto, as observações e falas sobre o uso dessas informações podem ir além das funções a que se propõem, podendo servir como instrumento para ratificar opiniões e preconceitos sobre os alunos e até mesmo para análise de conteúdo aprendido para rebaixamento do nível escolar do aluno.

\section{Considerações finais}

As análises apresentadas neste capítulo a partir de um estudo etnográfico com professores, gestores e alunos ilustram o fenômeno do fracasso escolar e da exclusão a luz de explicações e entendimentos dos próprios participantes. A tarefa interpretativa a que nos propusemos é limitadora dessas explicações e significados, mas nos auxilia a entender as 
práticas pedagógicas de modo mais claro e esta foi a intenção neste trabalho. Podemos derivar desse trabalho que o professor é portador de um potencial de controle que até ele mesmo desconhece. A nota dá um caráter quantitativo à qualidade do ser humano pois mede quanto ele vale para o sistema social e para o mercado (BRAGA, 2004). O "quanto vale" define o valor que a pessoa tem para a escola, a sociedade e o mercado. 0 critério econômico dado a nota restringe o indivíduo a uma única dimensão, desconsiderando as outras dimensões da sua existência emocional, cognitiva, cultural e social. Elas são também, pequenas decisões jurídicas, com status legal, que culmina em grandes e legitimadas decisões sobre as vidas das pessoas. O avanço na escola, a seleção para um nível mais alto de instrução, as expectativas de emprego e exclusão sócioeducacional são muitas vezes determinadas por estas decisões. No momento atual serve de base até para encaminhamento de alunos aos conselhos tutelares. Estes conselhos foram criados pelo Estatuto da Criança e do Adolescente para proteção e garantias de direitos da infância e da juventude. Processos que tem seu início nas escolas começam a circular nesses conselhos de modo a informar sobre a periculosidade de jovens e isso merece especial atenção de pesquisadores sobre o fracasso escolar por muitas vezes tornaram-se imperativos para empurrar os alunos para a marginalização social.

A presunção de que a escola irá fornecer um futuro melhor para seus alunos é um conceito idealístico. Os pais têm um desejo permanente de que seus filhos e filhas sejam bem sucedidos na vida e assim preparados para as incertezas que essa traz, entre o desejo de conseguirem uma vida melhor através da educação, e a satisfação do desejo de adquirirem uma boa vida após a escola, existe um obstáculo a que Mello (1983) chamou de "a mentira poderosa do sistema social". A "mentira poderosa" é que os estudantes são inatamente incapazes de tirar vantagem das oportunidades oferecidas pelo sistema escolar; um sistema que supostamente deveria fornecer igualdade para todos os alunos. Isto significa que uma criança não poderia ser bem sucedida na escola, por ser culpada pelo próprio insucesso. 


\section{Referências}

BASTIAN, A. et al. Choosing equality. Philadelphia: Temple University Press, 1986.

BORDONI, T. 0 nó: avaliação e aprendizagem significativa. Disponível em <http://7mares.terravista.pt/forumeducacao/ Textos/textoono.htm>. Acesso em 09/03/2004.

BRAGA, O. F. Notas sobre a nota na avaliação escolar. Disponível em <http://www.educacional.com.br/articulistas/ artigo0027.asp>. Acesso em 07/03/2004.

CONNELL R.W.; et al. Making the difference: schools, families and social division. Sydney; Boston: Allen and Unwin, 1982.

ERICKSON, F. Qualitative methods in research on teaching. In: WITTROCK, M.C. (ed.). Handbook of Research on Teaching. New York: Macmillan, 1986.

FINE, M. Perspectives on inequity voices from urban schools. In: Applied Social Psychology. Annual IV, Edited by Leonard Bickman. Beverly Hills: Sage, 1981.

HOFFMANN, J. Avaliação mediadora: uma prática em construção. Educação e Realidade. Porto Alegre, 1993.

JOHNSON, D. S. Naturally acquired learned helplessness: The relationship of school failure to achievement behavior, attributions, and self-concept. Journal of Educational Psychology, vol. $73, n^{\circ} .2, p .174-80,1981$.

MAMEDE, M. A. N. et al. $\mathbf{O}$ fracasso escolar e a busca de soluções alternativas: a experiência do NOAP. Petrópolis, RJ: Vozes, 1993.

MATTOS, C. L. G. Fracasso Escolar: Imagens e explicações populares sobre dificuldades educacionais entre jovens de áreas rural e urbana do Estado do Rio de Janeiro. Relatório de Pesquisa. UFF, PROPP, INEP/MEC/ CNPq, 1996. 
MATTOS, C. L. G. Metacognição em sala de aula: um estudo sobre os processos de construção do conhecimento na perspectiva do jovem infrator no Estado do Rio de Janeiro. Relatório de pesquisa, UERJ/ DEGASE, 2000.

MATTOS, C. L G. Picturing school failure: a study of diversity in explanations of educational difficulties of difficulties among rural and urban youth in Brazil. 1992. 268f. Thesis. (Ph. D. in Education) - Graduate School of Education, The University of Pennsylvania, Philadelphia. USA, 1992.

MATTOS, C. L. G. TEJA: Tecnologia educacional para jovens e adultos: enfrentando o fracasso escolar. Relatório de pesquisa. UERJ/ FAPERJ/ CNPq, 1998.

MELLO, G. N. Magistério de $\mathbf{1}^{\text {a }}$ grau: da competência técnica ao compromisso político. São Paulo: Cortez, 1983.

RAWLS, J. Théorie de la justice. Paris: Éditions du Seuil, 1997. RYAN, W. Equality. New York: Pantheon Books, 1981.

SIROTA, R. A escola primária no cotidiano. Porto Alegre: Artes Médicas, 1994. 


\title{
Os Ciclos e as Classes de Progressão na Rede Pública do Rio de Janeiro: percepções sobre a implementação, organização e práticas a partir das falas dos atores sociais da escola no período entre 2002 a 2004.
}

\author{
Paula Almeida de Castro \\ Tatiana Bezerra Fagundes \\ Carmen Lúcia Guimarães de Mattos
}

O objetivo deste capítulo é analisar aspectos da implementação, organização e práticas dos Ciclos de Aprendizagem e das Classes de Progressão a partir dos conteúdo das falas de alguns atores sociais da escola que vivenciaram estes programas compensatórios dentro da Rede de Ensino da Secretaria Municipal de Educação do Rio de Janeiro (SME/RJ) entre 2002 a 2004. Apresenta argumentos que sustentam a origem teórica dessas propostas no Brasil, assim como as práticas que se delinearam no âmbito da escola a partir de sua implementação. Ilustra com a percepção dos atores da escola as práticas ocorridas no contexto da implantação desses programas e os impasses gerados por eles.

O texto inclui corpus de dados obtidos em momentos distintos de pesquisa. O primeiro deriva de um estudo de cunho etnográfico realizado em uma escola de Ensino Fundamental da SME/RJ no período entre 2003 e 2004 coletados e analisados por Castro (2006) para sua dissertação de Mestrado. O segundo descreve análises de duas entrevistas, a primeira com uma aluna do Curso de Pedagogia da Faculdade de Educação da 
Universidade do Estado do Rio de Janeiro (FE/UERJ) que era professora da Classe de Progressão em 2003. A outra entrevista foi realizada com uma pesquisadora e professora da SME/RJ que vivenciou a implantação do programa enquanto coordenadora da Rede. As entrevistas pautaram-se nas discussão sobre os Ciclos de Aprendizagem e as Classes de Progressão, seu processo de implementação e práticas na escola.

O primeiro contato com esses temas envolveu a participação de alunos do Curso de Pedagogia da (FE/UERJ) na disciplina Pesquisa e Prática Pedagógica (PPP) classe de 2003 a 2008. Os dados foram coletados no contexto de uma das pesquisas coordenada por Mattos (2005) e desenvolvida no período entre 2002 a 2005. Estes estudos serviram de base para estudos posteriores desenvolvidos no âmbito do Núcleo de Etnografia em Educação (netEDU). Este texto reflete apontamentos iniciais do grupo sobre os Ciclos e as Classes de Progressão.

Do primeiro conjunto de dados (CASTRO, 2006) foram selecionadas de falas de professoras e gestores registradas em áudio e vídeo durante os conselhos de classes, assim como aquelas derivadas das observações e anotações de sala de aula. Esta pesquisa teve como objetivo verificar as formas de controle dos alunos pela escola e professora. Das análises realizadas infere-se que a organização dos Ciclos de Aprendizagem no período de sua implementação envolveu o antagonismo entre a concepções teórica que deu origem ao programa e as práticas das escolas. Infere-se, ainda que, como resultado houveram descompassos entre as práticas e os objetivos dos Ciclo. Em princípio estes visavam a superação da defasagem idade e série e da diminuição ou eliminação da repetência evitando o fracasso escolar.

Castro (2006) desenvolveu análises em sua dissertação que destacam categorias derivadas da pesquisa de campo e que abrangem temas como: corpo, tarefa, agressão, espaço, barulho, tempo, problemas de aprendizagem, problemas familiares, faltas, medicalização, violência, estigma, nota e conselho tutelar. $\mathrm{O}$ entrelaçamento entre estas categorias e o objeto de estudo do trabalho - o controle dos alunos pelos professores 
- foi permeado por práticas escolares e envolvem a organização das turmas de Ciclo que não serão objeto de discussão neste texto. Entretanto, a pesquisa colabora para situar o quadro da implementação dos Ciclos nas escolas

O segundo conjunto de dados, é originário de entrevista com a professora Souto, que trabalha na Rede da SME/RJ a mais de 20 anos, em atividades de ensino e coordenação de programas compensatórios. Ela é pesquisadora do tema desde 2002 (SOUTO; FONTOURA; MATTOS, 2002) e sua entrevista ilustra a situação da implementação e controvérsias mencionadas acima. Nesse conjunto de dados elegeu-se ainda uma entrevista com uma professora da Rede SME/RJ, aluna do $3^{\circ}$ período do curso de Pedagogia da Universidade do Rio de Janeiro em 2003 e que trabalhava aquele ano com alunos da Classe de Progressão, ao mesmo tempo em que atendia alguns desses alunos como explicadora, em seu tempo livre fora da escola.

\section{Os Ciclos na Rede Pública de ensino.}

Compreender Programas Compensatórios como os Ciclos de Aprendizagem e as Classes de Progressão a partir das falas dos atores escolares é importante porque auxiliam no desvelamento das práticas pedagógicas de sala de aula que orientam esses Programas nas escolas. As discussões sobre esses Programas entre os atores escolares que participaram destes estudos, principalmente os professores, revelam suas compreensões e considerações sobre os procedimentos a serem adotados face à possibilidade de reprovar ou não um aluno no conteúdo pedagógico de cada etapa do Ciclo.

Estas falas são reveladoras das dificuldades de entendimento por parte das professoras sobre o Ciclo e a Progressão. Elas questionavam sobre qual seria a proposta pedagógica a ser utilizada em sala de aula para atender a demanda dos Ciclos na prática diária, ao mesmo tempo em que gostariam de compreender como essas práticas poderiam evitar prejuízos aos alunos no que se refere a seus resultados acadêmicos. 
Segundo as professoras, experiências anteriores com propostas tidas como inovadoras contavam uma história de descontinuidade e fracasso, pois eram implementadas nas escolas mas continuavam a levar à reprovação e a repetência os alunos que nelas se incluíram. Esta preocupação por parte dos professores pode encontrar sustentação nas argumentações de Torres:

A repetência é um indicador claro da nãofuncionalidade e da ineficiência interna do sistema escolar, para a sociedade, em geral, e a comunidade educacional, em particular, professores, pais, estudantes, diretores, de liberadores de políticas nos distintos níveis, a repetência é aceita como algo "natural", como um componente inerente e até inevitável da vida escolar" (TORRES, 2004, P. 37).

Nos anos 80 estudos sobre a repetência escolar no Brasil como os de Brandão (et. ali., 1986) apontavam que:

[...] menos de um terço da clientela está na idade ideal para a série que frequenta os dois terços restantes encontram-se atrasados, seja porque entraram com mais de 7 anos na primeira série, seja porque abandonaram a escola por algum tempo, voltando mais tarde, seja porque repetiram alguma série (p.96).

Esses dados confirmam-se ao longo de duas décadas e se apresentam no Relatório de Desenvolvimento Juvenil publicado pela UNESCO em 2004, neste lê-se que:

[...] mais de $50 \%$ dos jovens não frequentam a escola. Mais grave ainda se torna a situação quando levamos em conta que, entre os que não estão na escola na faixa etária aludida [15 aos 24 anos] mais de 60\% não se encontram nas séries correspondentes às idades que possuem. O problema das distorções idade ou atraso escolar num país como o Brasil é preocupante. (...) em um sistema educacional seriado existe uma adequação teórica entre a série e a idade do aluno. No 
caso brasileiro, considera-se a idade de 7 anos como a idade adequada para o ingresso no ensino fundamental e a idade de 14 para a conclusão (p.60).

A cultura da repetência na escola e sua naturalização foi abalada, de certa forma, pela implementação dos Ciclos e da Progressão na SME/RJ, pois veio sinalizar, dentre outras coisas, que a escola teria que substituir um papel de transmissora de conhecimentos para facilitadora dos processos de conhecimentos. Este modelo de organização escolar tinha como premissa que o sujeito aprende em todos os momentos da vida sendo, portanto, necessário que a escola cultive valores sociais, culturais e familiares de todos os seus alunos e durante todo os períodos e fases de aprendizagem dos mesmos.

Tal prerrogativa parte do princípio que os programas escolares eram distanciados das questões sociais e alheios aos interesses e características dos alunos. A proposta era que os programas escolares refletissem diretamente à vida dos alunos, funcionando como elemento de veiculação com a unidade cultural a que pertencem, visando, não apenas a diminuição dos custos do governo com as reprovações, mas buscando uma visão global do aluno, valorizando a dimensão cognitiva, afetiva e social integrada à prática pedagógica.

O que vê-se, mais uma vez, é a contradição entre as propostas pedagógicas adotadas e a prática de sala de aula que gira em torno do cumprimento do currículo sem considerar a heterogeneidade do tempo de aprender de cada aluno. Neste contexto o trabalho Bourdieu (1998) explica que a escola:

[...] tende a ser considerada cada vez mais, tanto pelas famílias quanto pelos próprios alunos, como um engodo, fonte de uma imensa decepção coletiva: essa espécie de terra prometida, semelhante ao horizonte, que recua na medida em que se avança em sua direção (BOURDIEU, 1998 p. 221). 
Na proposta dos Ciclos da SME/RJ, aluno avançava mas ao chegar ao final do $1^{\circ}$ Ciclo ele retornava ao início do processo numa Classe de Progressão. Solução adotada para acelerar a aprendizagem de alunos que não conseguiram atingir as metas delineadas para cada etapa do Ciclo. O horizonte, mencionado por Bourdieu (1998), se afasta do aluno na medida em que ele retorna a situação de origem sem ser levado em conta o progresso obtido anteriormente.

Outra questão que envolve a repetência escolar e que levou a pensar em tais propostas foram as evidências relatadas nas estatísticas nacionais e internacionais sobre o alto custo representado para o governo com os alunos repetentes. A questão financeira que envolvia na Educação no Brasil originou-se, dentre outros, de estudos comparativos no exterior entre o Brasil e outros países indicados por dados internacionais de avaliação da escola básica em todo o mundo.

O tema repetência ou reprovação na Educação Primária ganhou destaque nas discussões educacionais, referindo-se à questão financeira Almeida Júnior (apud PATTO, 1999) afirmou, ser importante na época, que se procurasse solucionar o grave problema da repetência escolar e que constituía em importante prejuízos financeiro e retirada de oportunidades educacionais de uma considerável parcela da massa de crianças e jovens em idade escolar que não haviam tido oportunidades de entrar para escola.

Barreto e Mitrullis (2001) discutem os esforços implementados na tentativa de pensar uma solução pra esses custo do governo com as reprovações escolares. Segundo as autoras, a questão da organização escolar em Ciclos não é nova. Desde 1950, após a percepção de que havia uma grande retenção de alunos na escola primária brasileira, vêm-se discutindo o Ciclo - então entendido como promoção automática - a fim de diminuir o quantitativo de repetentes. Nesse escopo foram realizadas experiências de implementação dos mesmos no país, sobretudo ao longo das décadas de 60 e 70 sendo adotado por governos nos anos 80 . Contudo, a expressão maior da implementação de ciclos acontece na década de 90 . 
Anterior a esse período ainda no contexto das mudanças na organização escolar e curricular das escola surgiu a Lei de Diretrizes e Bases da Educação Nacional. Lei no 9.394 de 20 de dezembro de 1996 (LDB, 9394/96) que no artigo de $n^{\circ} 32$ prevê que o ensino pode ser organizado em Ciclo de aprendizagem, 0 texto da Lei estabelece que,

$\S 1^{\circ}$ É facultado aos sistemas de ensino desdobrar o ensino fundamental em ciclos. $\S 2^{\circ}$ Os estabelecimentos que utilizam progressão regular por série podem adotar no ensino fundamental o regime de progressão continuada, sem prejuízo da avaliação do processo de ensino-aprendizagem, observadas as normas do respectivo sistema de ensino.

A Lei (LDB, 9394/96) cria a possibilidade de implementação dos Ciclos, mas não obrigatoriamente:

A educação básica poderá organizar-se em séries anuais, períodos semestrais, ciclos, alternância regular de período de estudos, grupos não-seriados, com base na idade, na competência e em outros critérios, ou por forma diversa de organização, sempre que o interesse do processo de aprendizagem assim o recomendar (art. 23, p.34).

A proposta dos Ciclos está baseada na flexibilização do tempo de aprendizagem. Esta flexibilização pauta-se na importância do tempo de aprendizagem dos alunos tomando como princípio de que todos eram capazes de aprender. Entretanto, na prática observou-se que os professores continuaram a serem cobrados quanto ao tempo de cumprimento das atividades o que consequentemente levava a que eles conclamassem seus alunos a finalização das tarefas no tempo determinado.

A nova forma de organização do ensino em Ciclos era, antes de tudo, uma estratégia política e financeira de governo, num momento que a Educação brasileira mostrava altos índices de reprovações nas séries iniciais. As estatísticas do início dos 
anos 90 apontavam que de cada 100 crianças matriculadas na $1^{\mathrm{a}}$ série, apenas 16 concluíam as quatro séries do ensino primário após os 4 anos propostos para a sua duração.

A criação e implementação do Programa dos ciclos e seus critérios de avaliação devem ter em conta a formação e a preparação do professor para o enfrentamento do aumento da escolaridade dos alunos para além dos quatro anos. A medida que se pensa a ampliação dos anos de escolaridade no Ensino Fundamental nas Redes públicas, de 8 para 9 anos, essas discussões passam para o âmbito do Ministério de Educação que em 2004 publica relatório sobre o tema (MEC/SEB, 2004).

A literatura disponível que orienta os estudos que viabilizaram a implantação dos Ciclos de Aprendizagem no Brasil chega através de um conjunto de publicações veiculadas em âmbito acadêmico, em especial nos cursos de formação de professores na década de 90. Essas publicações revelam que a trajetória percorrida pelas escolas brasileiras, especialmente no Rio de Janeiro pautaram-se em muito nas teorias de ensino e aprendizagem do teórico suíço Phillippe Perrenoud.

A evolução da implantação dos Ciclos no Brasil foi objeto de estudo e pesquisas no Brasil, dentre estas destacaram-se os trabalhos de Barreto e Mitrullis (2001) e Barreto e Souza (2004). Além desses estudos, um vasto material foi fornecido pela Secretaria Municipal de Educação do Rio de Janeiro com o objetivo esclarecer a natureza desses Programas.

Também importadas foram algumas pressupostos teóricos das propostas de promoção de países cuja realidade sociocultural e cultural eram distintas do Brasil. Verifica-se entretanto, que seria preciso preparar os professores para receber estas propostas de ensino e de promoção de alunos.

Os Ciclos, em sua organização, compreendem períodos de escolarização que ultrapassam as séries anuais, organizados em blocos cuja duração varia, podendo atingir até a totalidade de anos prevista para um determinado nível de ensino. Perrenoud (2004) em seus estudos propôs uma pedagogia diferenciada que fosse capaz de promover avanços progressivos no conhecimento, respeitando os diferentes ritmos de aprendizagem 
de cada aluno. Esta diferenciação está fundamentada na qualidade dos tratamentos pedagógicos e didáticos, dispensados, sobretudo aos alunos que possuem dificuldades de aprendizagem, em detrimento do tempo de estudo.

Pressupondo que a proposta de Perrenoud (2004) deu origem aos Ciclos no Brasil, o autor em seu trabalho fala que os Ciclos representam a possibilidade de o aluno aprender em seu tempo respeitando assim os diferentes ritmos de aprendizagem. Dentro da escola existe a implementação da proposta de ciclos ligada ao regime seriado de ensino. Por isso os professores consideram que o aluno passa de uma etapa para outra.

Philippe Perrenoud em entrevista concedida exclusivamente por e-mail a Dreyer e Richbieter (s/d) ao site Portal Educacional, assinala que os Ciclos só existem de fato "quando a escolaridade é dividida em mais de um ano". Ele não exclui os balanços a serem feitos pelo professor ao final de cada ano. Estes balanços, na perspectiva do autor, funcionam apenas como um indicativo do desenvolvimento do aluno. O professor nesse sistema de ensino, desempenha o papel de condutor da aprendizagem no sentido de levar os alunos ao domínio dos objetivos escolares visados não apenas para o final do percurso mas desde a entrada dos mesmos. A partir desses pressupostos, Perrenoud considera sem sentido a repetição escolar, pois esta "implicaria um balanço e uma decisão ao fim de cada ano, e é exatamente isso que se deseja evitar no conceito de Ciclo”. O sociólogo suíço defende que "a repetição não é uma resposta eficiente as desigualdades”, pelo contrário, acentua-na: os alunos com dificuldades continuam a tê-las e além disso são vítimas de estigmas. Portanto, não há nenhuma vantagem em fazer um aluno repassar, no caso, pelo Ciclo do qual fez parte outrora.

Barreto e Sousa (2004) em seu estudo fazem um balanço da situação dos Ciclos e das Classes de Progressão no Brasil, ressaltando as experiências dos Estados de São Paulo, Belo Horizonte e Porto Alegre, através da revisão bibliográfica em teses sobre o tema no período entre 1980 à 2002. As autoras em uma perspectiva histórica sobre ciclos no país, consideram que seu objetivo é regularizar o fluxo de alunos ao longo do processo 
de escolarização "a fim de assegurar que todos possam cumprir os anos de estudos previstos para o ensino obrigatório, sem interrupções e retenções que inviabilizem a aprendizagem efetiva e uma educação de qualidade” (p.33). Vale ressaltar que os Ciclos têm recebido diversas denominações tais como: bloco único, promoção automática, avanços progressivos, progressão continuada, classes de aceleração, dentre outros.

Os estudos de Barreto e Sousa, realizados em 2002, consideram que somente $19,4 \%$ das escolas entre públicas e privadas organizavam-se em ciclos no Brasil. Na época, a grande maioria delas encontravam na região Sudeste; 10,9\% adotavam unicamente o sistema de Ciclos e 8,5\% combinavam Ciclos e séries.

As autoras descrevem estas experiências nas cidades de São Paulo, Belo Horizonte e Porto Alegre evidenciando objetivos diferenciados entre as propostas. São Paulo tinha como objetivo para a escola a participação, descentralização e autonomia. A partir daí houve uma iniciativa de reorientação curricular no sentido de levar à interdisciplinaridade. No bojo desse processo inseriu-se a proposta de Ciclos que abrangeu todas as escolas municipais com incentivo do governo. A implementação dos Ciclos ocorreu num clima de grande aceitação por parte dos professores e outros atores educacionais. Contudo, não houve continuidade devido a trocas de governos e diferenças ideológicas entre o grupo gestor e o que o sucedeu.

Em Belo Horizonte, a proposta político-pedagógica que norteou a mudança na rede escolar de ensino foi a da Escola Plural. Tal proposta, amplamente divulgada no ano de 1994 foi implementada em 1995. A Escola Plural teve como objetivo redefinir aspectos considerados significativos na sua estrutura e funcionamento com vistas a permitir que novas formas de organização favorecessem o desenvolvimento de experiências formadoras (p.41). Barreto e Sousa (Idem) percebem na rede pública de ensino de Belo Horizonte que a proposta de Ciclos de Aprendizagem foi bem sucedida, tornando-se inclusive referência para outros estados e municípios do Brasil até a presente data. 
Já em Porto Alegre, na tentativa de evitar a evasão escolar, a escola organiza-se em Ciclos de formação com o propósito de garantir a aprendizagem dos alunos sem interrupções. As fases do desenvolvimento da infância foram consideradas na elaboração dessa proposta. Contudo, o que foi destacado pelas autoras, é que não houve continuidade no município de Porto Alegre de pesquisas que pudessem comprovar ou não a eficácia do Programa.

Na SME/RJ os Ciclos foram implementados no primeiro segmento do Ensino Fundamental e serviram para substituir a seriação nos três primeiros anos desse segmento. Nos ciclos de alfabetização, a criança tinha até três anos para desenvolver suas habilidades de leitura e escrita sem risco de reprovação. A criança que, por algum motivo não alcançasse esse objetivo, era encaminhada para a Classe de Progressão.

A partir de 2000, as escolas do Ensino Fundamental SME/RJ implantaram gradativamente o sistema de ciclos de formação e foram se adaptando a este novo sistema abandonando a seriação. O desenvolvimento das classes de progressão nas escolas da SME/ RJ foi objeto de várias pesquisas na época de sua implantação, destaca-se dentre estas a investigação de uma professora desta Rede publicada em dissertação de Mestrado (SPALA, 2005).

A institucionalização do regime de Ciclos de Formação na SME/RJ se deu pela Resolução 684 de abril de 2000. Nesta, observa-se que a implantação foi pensada de forma gradativa. Documento preliminar a esta regulamentação foi encaminhado pela SME/RJ em 1999 a profissionais das escolas que o avaliaram. Este documento mostra a organização curricular dos Ciclos da seguinte maneira:

Quadro 1 - Organização curricular em Ciclos

\begin{tabular}{|c|c|c|c|}
\hline Ciclos de Formação & Séries & Duração & $\begin{array}{c}\text { Implementação } \\
\text { prevista }\end{array}$ \\
\hline $1^{\circ}$ Ciclo & $\mathrm{CA}, 1^{\mathrm{a}}$ e $2^{\mathrm{a}}$ & 3 anos & $2000 / 2001$ \\
\hline $2^{\circ}$ Ciclo & $3^{\mathrm{a}}$ e $4^{\mathrm{a}}$ & 2 anos & $2001 / 2002$ \\
\hline $3^{\circ}$ Ciclo & $5^{\mathrm{a}}$ e $6^{\mathrm{a}}$ & 2 anos & $2002 / 2003$ \\
\hline $4^{\circ}$ Ciclo & $7^{\mathrm{a}}$ e $8^{\mathrm{a}}$ & 2 anos & $2002 / 2003$ \\
\hline
\end{tabular}

Fonte: SME, do Rio de Janeiro, 1999. 
A Proposta dos Ciclos tinha a intenção de regularizar o fluxo de alunos ao longo da escolarização, eliminando ou limitando a reprovação e a repetência, entretanto houveram descontinuidades administrativas e problemas em seu funcionamento o que resultou no surgimento das Classes de Progressão. Estas tinham com objetivo de permitir mais uma vez ao aluno completar o domínio da leitura e da escrita antes de continuar os estudos na $3^{\circ}$ série ou no $2^{\circ}$ Ciclo.

Embora na teoria a progressão continuada dos alunos fosse prevista como premissa principal da proposta dos Ciclos, o surgimento desta nova modalidade de agrupamento das turmas, deu origem as chamas das Classes de Progressão I e Progressão II, onde os alunos, na prática eram classificados de acordo com as antigas formulações de ensino seriadas e após o período de 3 anos tinham possibilidade de serem retidos antes de ingressarem na $3^{\mathrm{a}}$ série ou no $2^{\circ}$ Ciclo de aprendizagem.

Entretanto, o mesmo ruído de interpretação sobre o objetivo prático da proposta das Classes de Progressão, assim como a insatisfação por parte de pais, responsáveis e professores, culminou com a sua extinção no ano de 2007, entretanto, a proposta foi assimilada e modificada transformando-se em outros outras formas de organização curricular e pedagógica que coexistem nas escolas da Rede SME/RJ. Projetos nomeados de como "se liga" e "acelera", dentre outros.

O entendimento da Proposta dos Ciclos assim como das Classes de Progressão gerou e continua gerando dúvidas por parte dos professores sobre o como desenvolvê-la. Estes não chegaram a um consenso acerca dos conteúdos previstos para cada etapa do Ciclo e quanto aos processos de avaliação e de retenção e reprovação de seus alunos. Na maioria dos casos, a percepção desses professores é de que na impossibilidade dos alunos serem reprovados eles passam pelos Ciclo sem adquirirem os conteúdos básicos de cada etapa. Este entendimento evidencia a falta de coincidência entre os estratos teóricos que apoiam esses programas e a prática pedagógica do professor. 
De acordo com a analise de Lima (2002) sobre a apostila de orientação pedagógica proposta pela Secretaria Municipal de Educação do Rio de Janeiro, a classe de progressão era destinada a:

[...] crianças 'empacadas' na aprendizagem da escrita, aquelas que com 9 ou 10 anos, continuam escrevendo pouquíssimo, com muitos equívocos, sem conseguir montar uma frase, comunicar uma ideia, ou aquelas que escrevem usando fileiras de letras incapazes de representar em grafemas os fonemas da língua portuguesa, são crianças que precisam passar por situações de aprendizagem que retomem 'todos' os aspectos da escrita não constituídos, por meio de uma metodologia que recorra, de um lado, aos componentes do sistema (a escrita se adquire pelo domínio dos componentes, das regras e da estruturação desse sistema), de outro, a natureza cultural da apropriação e do uso desse sistema (LIMA, 2002, p.12).

Buscamos, em entrevista realizada em junho de 2005, com Souto, compreender o que ocorria, em sua opinião, nas escolas da SME/RJ na época. Responsável por trabalhos de professores de Classes de progressão localizadas em uma escola da Zona Oeste do Rio de Janeiro, seu interesse em lidar profissionalmente com estas classes, assim como pesquisá-las, surgiu através da sua percepção de que o quantitativo de alunos que não aprendem vinha aumentado cada vez mais e como consequência eles estavam sendo excluídos do contexto escolar, apesar da intenção de incluir que a proposta continha.

Segundo a entrevistada, a Classe de progressão era destinada a alunos com defasagem idade-série e que não estavam alfabetizados. Os alunos encaminhados para esta classe eram aqueles que não conseguiram desenvolver efetivamente a habilidade de leitura e escrita no Ciclo e se encontravam em diferentes níveis no processo de aquisição da lecto-scritura. 
Quando perguntada sobre o que é a classe de progressão a partir da visão trazida pela pesquisa, a pesquisadora disse que a classe de progressão se constitui enquanto classe de alunos excluídos do contexto escolar. $\mathrm{O}$ aluno já chega nessa classe rotulado e ninguém acredita que ele tenha condições de aprender. A pesquisadora ressalta que o aluno se coloca no lugar de culpado por não corresponder à expectativa do professor.

Ela apontou, ainda, para o fato de que nessas classes existiam alunos com diferentes níveis de idade e aprendizagem, o que resultava em uma variabilidade no domínio dos conteúdos que diziam respeito à leitura e a escrita. Entretanto, o que a pesquisadora percebeu é que o trabalho realizado na Progressão acontecia de forma única, ou seja, não se respeitava os diferentes níveis que se apresentam dentro dessas classes. Os alunos eram submetidos aos mesmos conteúdos independentemente do que já haviam aprendido enquanto estiveram na classe do Ciclo.

Ao ser questionada sobre uma proposta para a Progressão a pesquisadora defendeu a necessidade de uma pedagogia diferenciada que respeitasse o nível de aprendizagem de cada aluno. Nessa pedagogia o professor deve ter a convicção de que o aluno é capaz de aprender e a partir daí, tentar da melhor maneira possível, sensibilizá-lo para tal fato. Ressaltou ainda que a Classe de Progressão constituiu-se também como uma estratégia política para gerar vagas e assim captar recursos financeiros para a escola.

A segunda entrevista destaca a visão de uma professora sobre a Classe de Progressão. A professora entrevistada trabalhou durante um ano e meio em uma classe de progressão como professora de uma escola da Zona Norte do Rio de Janeiro. Seu tempo de permanência na classe foi do período de $07 / 2002$ a 12/2003. Após deixar a classe a professora continuou seu trabalho dando aulas particulares aos alunos que, mesmo dentro das classes de progressão encontravam dificuldades no processo de aprendizagem. Esta entrevista realizada em junho de 2005, na mesma época que a entrevista com a pesquisadora. As falas 
da professoras referem-se a dinâmica da Classe de Progressão em que ela trabalhou. Quando perguntada sobre o que é classe de progressão ela repondeu:

Bom, classe de progressão é uma classe onde se coloca alunos que não conseguem desenvolver a tarefa no decorrer do ano. Esses alunos, depois que aprendem, são inseridos de novo na classe regular. [...] Seria fazer o aluno aprender num ano só o que ele não consegue alcançar. $\mathrm{O}$ aluno na classe de progressão teria que aprender o conteúdo da série que ele não assimilou e o conteúdo da série que estaria aprendendo no ano, porque se ele fosse continuar na progressão ele ia continuar atrasado.

Quanto a dinâmica de salas de aula na sua classe de progressão, o conteúdo pedagógico e domínio da leitura e da escrita pelos alunos, a professora comenta:

Era uma aula normal, apenas você via que o conteúdo não coincidia com a idade do aluno. É porque você não tem o costume de ver um aluno com dez anos aprendendo a-ei-o-u. Você via que eram coisas muito infantis para a idade das crianças. Não, tinham as que sabiam as vogais, mas que não sabiam juntar. São crianças que você pode chamar assim, de analfabeta. Essas classes de progressão eram classes com crianças de dez, onze anos de idade.

A professora comentou que observara nessas classes crianças que não tinham tantas dificuldades com a matemática e a geografia, quanto com a leitura e a escrita. Ela apropria-se da teoria de Perrenoud e diz:

[...] na teoria de Perrenoud não acontece isso, as crianças tinham que aprender outros conteúdos, matemática, geografia, etc., eu não vejo nessas classes crianças com esse tipo de dificuldade." 
Ao ser perguntada sobre qual seria a proposta de Progressão que ela, como professora, aplicaria a esta Classes, ela disse:

\begin{abstract}
Bom, se eu for definir progressão, pra mim é uma coisa que você leva adiante. Eu dividiria, não botaria tudo junto na mesma classe, eu separaria.
\end{abstract}

$\mathrm{Na}$ entrevista é feita menção aos Centros Integrados de Educação Pública (CIEPs) e a proposta de ensino em tempo integral que orientou esse Projeto, para exemplificar como as Classe de Progressão deveriam funcionar.

Os CIEPs em seu projeto original visavam a implementação de escolas de horário integral no Rio de Janeiro. A ideia da construção de escolas de horário integral esteve vinculada com uma proposta política do então governador Leonel Brizola e do vice-governador e secretário de Estado e Cultura, Ciência e Tecnologia, Darcy Ribeiro sendo o projeto arquitetônico desenvolvido por Oscar Niemeyer. O funcionamento previsto para o CIEPs seria de oito horas, dividas em desenvolvimento do currículo básico, atividades de animação cultural, estudo dirigido e educação física. As escolas previam também centros de saúde com atendimento médico e odontológico, biblioteca, entre outras coisas.

Ná época de sua implantação, a proposta das escolas de horário integral era vista como utópica pelos próprios educadores que passaram por treinamentos para desenvolveram suas atividades pedagógicas em oito horas diárias. O que vemos, entretanto, é que os CIEPs não se constituíram em um espaço educativo inovador, pois ficou atrelado a ideais políticos divergentes. Alguns CIEPs foram entregues à administração municipal e passaram a integrar o projeto político pedagógico do município.

De acordo com a entrevistada, haveria necessidade de o aluno estar na escola em tempo integral como o CIEP, onde pela manhã frequentasse a Classe de Progressão e à tarde participasse de atividades no Ciclo. Ela comenta que se o aluno tem dificuldade em um sistema, não vai conseguir aprender no outro. Referindo-se à dificuldade que 0 aluno poderia encontrar ao retornar a classe do Ciclo após sua passagem pela Progressão. 
Ao ser perguntada se ela havia visto algum aluno sair da classe de progressão durante o período em que trabalhava na escola a professora diz, "Olha, sair, a gente sempre vê...”, explicando que quando este aluno retornava ao Ciclo deparava-se com dificuldades maiores, pois o conteúdo trabalhado na Classe de Progressão não eram correspondente ao trabalhado do Ciclo. Como exemplo ela cita que os alunos que estavam na $1^{\mathrm{a}}$ série mas que não conseguiam alcançar os objetivos propostos para esta série até o final do ano, passavam para a Classe de Progressão no ano seguinte. Este deveria estar na $2^{\mathrm{a}}$ série, mas continuavam aprendendo conteúdos correspondentes à $1^{\mathrm{a}}$ série. Alcançados os conteúdos da $1^{\mathrm{a}}$ série ou $2^{\mathrm{a}}$ série, o aluno retornaria no próximo ano para a sua classe de origem no Ciclo. A professora chamou a atenção para a dificuldade que este aluno encontrava quando era reengajado na turma do Ciclo, em especial quando esta era correspondente à $3^{\mathrm{a}}$ série. Ela utiliza a terminologia "série" o que indica um entrelaçamento entre os dois sistemas de organização: as fases do ciclo e as série. Este mesmo entrelaçamento , verifica-se na continuidade desses Programas compensatórios com a implementação do Ensino Fundamental de 9 anos, quando terminologias como ano escolar, Ciclos e séries confundem-se nos discursos dos atores escolares, assim como dos responsáveis. Na entrevista a professora diz que o aluno que retornava, eventualmente para o Ciclo, acabava voltando para a Classe de Progressão posteriormente. A entrevistada fala que:

O aluno aprendeu a ler, mas não sabe interpretar e resolver um problema de matemática [...] É por isso que eu recebo alunos querendo aula particular, é por isso, porque eles não aprendem.

A professora conclui suas reflexões na entrevista manifestando o desejo de pesquisar uma Classe de Progressão no local onde trabalhou e as dificuldade que teria pela possível resistências de suas colegas professoras, ela diz:

Se você for lá, eles vão dizer que não é isso que acontece. E aquilo tá errado, mas não vão admitir. 
As duas entrevistas realizadas não coincidem quanto as explicações sobre a natureza do projeto pedagógico do Ciclo e da Classe de Progressão. De acordo com a professora entrevistada a articulação entre o ciclo e a classe de progressão acontece da seguinte maneira:

[...] aluno ao final do ano não consegue alcançar os objetivos propostos, vai para a classe de progressão. No ano seguinte, da progressão, este passa de ano de acordo com os conteúdos que consegue ou não assimilar na classe do Ciclo. Um ano após passar pela classe de progressão o aluno volta para o Ciclo a fim de dar continuidade aos estudos escolares.

Chamou-se a atenção anteriormente na fala da professora para o fato de que ela utilizou a terminologia "série" para explicar o movimento de passagem de ano do aluno dentro do Ciclo. Diferente da professora, a pesquisadora entrevistada relatam que nas escolas por ela coordenada e pesquisada, o aluno que ao final de três anos não conseguisse alcançar o objetivo proposto para o Ciclo, era encaminhado à Classe de Progressão até adquirir conhecimento que não conseguiu ao longo dos três anos no Ciclo.

As falas de atores da escola descritas em pesquisa posterior as entrevistas mencionadas subsidiam a afirmação de que existia uma falta de clareza entre professores sobre a proposta dos Ciclos de Aprendizagem e das Classes de Progressão na época de sua implementação e ao longo do desenvolvimento da proposta na escola. A sala de aula é vista como o locus de construção das relações intra-escolares, onde poderia ser observado um sentido para a superação dessas proposta, pois de acordo com Cajal:

A vida de sala de aula, como a de qualquer outra situação social, não é dada a priori, nem tomada de empréstimo a outra situação, ao contrário, é construída, 'definida e redefinida' a todo o momento, revelando e estabelecendo os contornos de uma interação em construção. Interação enquanto 
(encontro) em que os participantes, por estarem na presença imediata uns dos outros, sofrem influência recíproca, daí negociarem ações e construírem significados dia a dia, momento a momento (CAJAL, 2001, p.127).

Essa construção diária na sala de aula implica no estabelecimento interações que possam promova a inclusão dos alunos sem que para isso ocorram interpretações pré-concebidas das capacidades e formas de progresso que este possuem. Nesta perspectiva a sala de aula se configura como um espaço interacional que interfere na vida daqueles que dela participam. Por isso a importância de estudá-la e voltar a ela toda vez que buscamos compreender a dinâmica que ocorre em seu interior.

$\mathrm{Na}$ escola onde foi realizada, a pesquisa de campo trabalho estas salas de aula, compreendiam algumas das características mencionadas nas entrevistas anteriores como ideias para o sucesso da proposta de Ciclos e Progressão, seu funcionamento era em horário integral e atividades eram criadas a partir das necessidades dos alunos e dos conteúdos pedagógicos. Uma dessas atividades era a recuperação paralela, onde os alunos com baixos rendimentos escolares frequentam em horários especiais aulas extras no intuito de melhorarem seu desempenho acadêmico.

Foi possível perceber através das observações diárias, do discurso e da prática dos professores como funcionavam essas salas de aula. As aulas extras, por exemplo, eram consideradas pelos seus atores como um esforço de implementação dessas políticas pedagógicas e visavam a criação de uma escola inclusiva, humanitária, voltada para o atendimento das necessidades educacionais de seus alunos. Entretanto, suas práticas eram excludentes e evidenciavam as lacunas a ser preenchidas. Uma delas estava relacionada a necessidade de controle dos alunos pelos professores.

Tantos foram os equívocos observados na proposta de implementação do ciclo e a realidade escolar que os professores tentavam, durante os Conselhos de Classe, discutir o significado 
das mesmas. Em uma das conversas durante o conselho, eles levantaram a seguinte argumentação:

\begin{abstract}
Acho que daí o nome ciclo... É uma coisa cíclica... Um faz e o outro continua e o outro também.[...] Ah aí a outra turma vai achar que eu não ensinei direito. [...] A gente sabe que são crianças que tem problema. Vem pra cá de mãos abanando. [...] A gente sabe dos problemas, mas no mapa estão outros. [...] 0 índice mostra as expectativas de cada uma. A minha preocupação não é com o trabalho do professor, mas por não saberem ler e poderíamos salvá-los da progressão. É melhor pegar uma turma de vinte com seis com dificuldade, mas só aqueles que têm uma chance. [...] na $4^{\mathrm{a}}$ série eles não estão sabendo chegar, a gente dá um teste para eles chegarem num nível de $4^{\mathrm{a}}$ série, a gente trabalha alfabetização, sala de leitura, mas eles saem da $3^{\mathrm{a}}$ sem saber... então a lacuna que está quando saindo do ciclo. [...] a lacuna está no ciclo. [...] não do começo até o final.
\end{abstract}

Essas falas durante a discussão no Conselho de Classe revelam as dúvidas que esses atores tinham sobre as propostas dos Ciclos e da Progressão e demonstra a compreensão enviesada das mesmas sobre o funcionamento e a finalidade do ensino em Ciclos de aprendizagem que se estabeleceu nas escolas.

A proposta dos ciclos tinha como objetivo valorizar o tempo de aprendizagem do aluno, contudo, tal objetivo não se efetivou, pois a estrutura escolar favorece a organização das Classes com o propósito de homogeneizar e manter todos os alunos seguindo o mesmo ritmo.

\title{
Considerações Finais
}

A partir de nossas análises sobre os textos lidos e as entrevistas realizadas, o que percebemos é que existe uma grande distância entre a proposta dos ciclos e sua implementação e desenvolvimento no contexto escolar. 
No Rio de Janeiro, a Classe de Progressão foi um espaço que não deu conta de alcançar o seu objetivo de subsidiar o aluno para que o mesmo retornasse à sua classe anterior sem prejuízo no seu processo de aprendizagem. As falas trazidas ao texto da pesquisadora e da professora no que diz respeito a Classe de Progressão evidenciaram que as mesmas se constituíram em mais um local de produção do fracasso escolar.

Enquanto Perrenoud defende o Ciclo como possibilidade de superação do fracasso, na SME/RJ o que ocorreu foi o agravamento do fracasso de alunos, assim como o deslocamento da questão da aprendizagem para a questão da superação da defasagem idade e série.

Com a introdução de propostas como estas na rede de ensino, acredita-se que seja de extrema importância estudos que deem conta de explicar o que ocorre não só em classes onde se aplicam os programas em si, mas nas propostas que os antecederam nos resultados obtidos

Entende-se que à escola devem ser dadas medida de autonomia. Contudo, se pretende-se uma escola e um sistema escolar integrado, articulado e democrático, acredita-se que deva existir um amplo espaço de diálogo entre as escolas que compõem o sistema de ensino. 0 que se percebe nas percepções dos atores escolares é que entre as escolas de uma mesmo sistema, existem diferentes concepções de implementação, de organização e de entendimento sobre o funcionamento se programas como dos Ciclos e das classes de Progressão.

Conclui-se que soluções plausíveis para minimizar os problemas educacionais no âmbito escolar precisam fomentar uma escola que leve em conta a diversidade de sua clientela como principais atores de seus processos de escolarização. Os Ciclos, assim como a Progressão podem ser uma dessas soluções, entretanto os debates educacionais, sobretudo para a formação de professores devem incluí-los de forma critica e sensível a cada aluno do sistema e não como uma formula que serve para todos. 


\section{Referências}

BARRETO, E; MITRULIS, E. Trajetórias e desafios dos ciclos escolares no País. Estudos Avançados, v. 15, n. 42, 2001.

BARRETO, E. S. de S. ; SOUSA, S. Z. Estudos sobre ciclos e progressão escolar no Brasil: uma revisão. Educação e Pesquisa, jan./ abr. 2004, vol 30, no. 1, p.31-50. ISSN 1517-9702

BOURDIEU, P. (coord.). A miséria do mundo. Petrópolis: Vozes, 1998.

BOURDIEU, P. Os usos sociais da ciência: por uma sociologia clínica do campo científico. São Paulo: Editora UNESP, 2004.

BRANDÃO, Z.; et. al. A escola em questão: evasão e repetência no Brasil. Rio de Janeiro: Dois Pontos, 1985.

BRASIL. Lei de diretrizes e bases da educação: Lei n. 9.394/96. Brasília: DP\&A, 2000.

COX, M. I.; ASSIS-PETERSON, A. A. (org.). Cenas de sala de aula. Campinas: Mercado de Letras, 2001.

CURY, C. R. J. Lei de Diretrizes e Bases de Educação. Lei 9394/96. Rio de

DREYER, D.; RICHBIETER L. O pensador dos ciclos. Entrevista com Philippe Perrenoud. E-educacional. Disponível em: <http:// www.educacional.com.br/entrevista/entrevista0108asp >. Acesso em junho de 2005.

ERICKSON, F. Ethnographic microanalysis of interaction. In: LECOMPTE, M. D.; MILLROY, W. L.; PREISSLE, J. (org.) The handbook of qualitative research in education. New York: Academic Press, 1992.

ERICKSON, F.; MOHATT, G. Cultural organization of participation structures in two classrooms of indian students. In: SPINDLER, G. (org.). Doing the ethnography of schooling. New York: Holt, Rinehart Winston, 1982. 
MARCHESI, A; GIL, C. H. (org.). Fracasso escolar uma perspectiva multicultural. Porto Alegre: ArtMed, 2004.

MATTOS, C. L. G. de. Etnografia crítica de sala de aula: o professor pesquisador e o pesquisador professor em colaboração. Revista da Ciência da Educação: Educação e Sociedade, CEDES e PAPIRUS: ano XVI, nº 51, Agosto 1995.

MATTOS, C.L.G. Imagens da Exclusão. Relatório da Pesquisa. UERJ, 2005.

MEC/SEB. Ampliação do ensino fundamental para nove anos. Relatório do programa. Secretaria de Educação Básica do Ministério da Educação: Brasília-DF, 2004.

PATTO, M. H. S. A produção do fracasso escolar: histórias de submissão e rebeldia. São Paulo: Casa do Psicólogo, 1999.

PERRENOUD, P. Os ciclos de aprendizagem. Um caminho para combater o fracasso escolar. Porto Alegre: Artmed, 2004.

PERRENOUD, P. Ofício de aluno e sentido do trabalho escolar. Porto: Porto Editora, 1995.

SME-RJ. Espaço Progressão. Documento de Orientação pedagógica das Classes de Progressão Rio de Janeiro, 2004.

SOUTO, R. M dos S.; FONTOURA, H. A. da; MATTOS, C. L. G. de. Sucesso Escolar: alunos superando a exclusão. II seminário Nacional-Produção do Conhecimento e educação: histórias, utopias. 19 a 22 de agosto. Programa de Pós-graduação em Educação da Universidade Federal Fluminense, Niterói, 2002. 



\section{Programa Especial Adolescente 2007 para alunos em de 14 e 15 anos de idades: um estudo de caso etnográfico em uma Escola da Rede Pública Municipal do Rio de Janeiro.}

Carmen Lúcia Guimarães de Mattos Adriana Maria Ribeiro Gil Ferreira

Este capítulo apresenta um estudo de caso etnográfico sobre o Projeto Especial Adolescentes (PEA) em uma escola da Rede de Ensino Infantil e Fundamental da Secretaria Municipal de Educação do Rio de Janeiro (SME/RJ). Os dados, coletados em 2007, compõe o acervo da pesquisa 'Imagens Etnográficas da Inclusão Escolar: o fracasso escolar na perspectiva do aluno', coordenada por Mattos (2008) e desenvolvida pela equipe de pesquisadores do Núcleo de Etnografia em Educação (netEDU) da Universidade do Rio de Janeiro (UERJ) no período de 2005 a 2008.

O estudo de caso etnográfico foi incluído nas análises dos dados que compõe parte do trabalho de conclusão de curso em Pedagogia da Faculdade de Educação (FE) da UERJ de Ferreira orientada por Mattos. O objetivo do trabalho de Ferreira foi analisar e interpretar o significado para os atores sociais da criação, implementação, desenvolvimento e finalização do PEA. Parte dos resultados de Ferreira (idem) foi selecionado com o objetivo de estudar a natureza das atividades e das interações entre os alunos e o professor da Classe do PEA. Assim, este capítulo contém análises descritivas e críticas ao PEA, envolvendo particularidades do atendimento aos adolescentes atendidos pela escola participante do estudo assim como dos atores sociais que colaboraram com a pesquisa. 


\section{Sobre o Projeto Especial Adolescente (PEA)}

Em 2007, a SME/RJ modificou o sistema de organização escolar em sua rede de ensino e ampliou o Ciclo de Formação, antes limitado ao $1^{\circ}$ Ciclo, para todo o Ensino Fundamental. O documento oficial com indicações para a promoção desta mudança estabeleceu o seguinte:

No que se refere à estruturação das turmas, tomou, como referencial, as fases do desenvolvimento humano: $1^{\circ}$ Ciclo de Formação: infância (seis a oito anos); $2^{\circ}$ Ciclo de Formação: pré-adolescência (9 a 11 anos); e $3^{\circ}$ Ciclo de Formação: adolescência (12 a 14 anos). Para os adolescentes, com 14 e 15 anos, oriundos das turmas de Progressão e que ainda não consolidaram o processo de leitura e escrita, foi criado o "Projeto Adolescentes", coordenado pela Diretoria de Ensino Fundamental do E/DGED, em parceria com as Divisões de Educação das Coordenadorias Regionais. Este projeto estabelece atendimento aos alunos em horário integral, com atividades culturais e de apoio à aprendizagem, além da formação continuada para os professores e acompanhamento efetivo do Nível Central da SME e do Nível Intermediário - as Coordenadorias Regionais de Educação (CREs) (SME/RJ, 2007 p.11).

O documento salienta que esta forma de organização deve ser associada a outras estratégias que deveriam ser estabelecidas pelas escolas para a 'estruturação das turmas' com o objetivo de atender aos alunos que apresentassem defasagem idade-série, de forma a garantir a 'adequação pedagógica às necessidades educacionais' desse grupo de alunos. Estabelece ainda que, dentre essas estratégias a ênfase deveria ser dada para: a recuperação paralela, o apoio pedagógico, o reagrupamento e os centros de estudos. No documento essa orientação é a seguinte: 
Recuperação paralela - A recuperação paralela é um mecanismo de apoio determinado pela própria LDB, dirigida aos alunos que apresentem dificuldades ou que tenham ingressado tardiamente na escola. Cabe ao professor regente a orientação específica, adequada às necessidades educacionais de cada aluno, possibilitando, através de novos caminhos pedagógicos, novas estratégias com 0

Apoio pedagógico - Caso persistam as dificuldades de aprendizagem, o aluno poderá ser atendido pelo professor de apoio pedagógico que trabalhará em conjunto com o professor regente, tanto na elaboração do planejamento e realização de atividades, quanto no processo avaliativo.

Reagrupamento - A partir do mapeamento das habilidades de professores e alunos e do levantamento das necessidades educacionais destes últimos, a escola deverá realizar, o reagrupamento de seus alunos. Esta ação pressupõe um trabalho coletivo, em que todos os professores são responsáveis pela aprendizagem de todos os alunos. Atividades diversificadas e específicas para cada grupamento deverão possibilitar a inclusão e o desenvolvimento de todos.

Centros de Estudos - Os Centros de Estudos, tanto para alunos, como para professores, se constituem em espaços privilegiados da aprendizagem coletiva no sistema ciclado (SME/RJ, 2007 p.12).

Com a previsão de término no mesmo ano, o PEA visava o atendimento dos alunos com idades entre 14 e 15 anos oriundos de escolas da Rede Municipal que faziam parte da extinta Classe de Progressão no ano de 2006 (SME/RJ, 2008). Os alunos que estavam nas Classes de Progressão e que ainda não haviam consolidado o processo de leitura e escrita, deveriam ser separados, reagrupados e distribuídos nas 38 escolas onde foram 
criadas as Classes de Projeto, formando no total 42 turmas. Nelas, o atendimento aos alunos se daria em horário ampliado, com atividades culturais e de apoio à aprendizagem, além da formação continuada para os professores e acompanhamento à nível central por especialistas da SME/RJ e à nível intermediário pelas CREs.

Nessas classes os alunos deveriam receber uma formação de caráter acelerado e durante o período de um ano seriam avaliados, através de relatórios de acompanhamento pelo professor regente da turma. De acordo com os rendimentos, os alunos seriam reinseridos nos agrupamentos de classes regulares, que fossem mais apropriadas à sua faixa etária (SME/RJ, 2007).

Destaca-se que a avaliação desses alunos de acordo com a Resolução n 776 (SME/RJ, 2003), deveria seguir o que está estabelecido no Art. $5^{\circ}$ "A avaliação dos alunos das Classes Especiais deverá ser expressa nos relatórios de observação inicial e de acompanhamento". Portanto, nessa avaliação, não haveria notas ou conceitos, ela seria baseada na análise do desenvolvimento do aluno incluindo avanços e recuos percebidos pelo professor. Estes movimentos deveriam ser descritos em relatório detalhado que seria anexado ao Registro de Classe. Este Registro é um documento oficial que serve como fonte de informação sobre a vida do aluno e deve estar sempre atualizado e corretamente preenchido em todos os seus itens. De acordo com a SME, a guarda desses Registros é de responsabilidade da Direção da escola e está sujeito a fiscalização não podendo ser retirado da Unidade e nem mantido em local inadequado (SME/RJ, 2007). Neles deveria constar todo e qualquer recurso interposto pela escola ou pelos pais e responsáveis em relação ao aluno.

A turma deveria ser regida por apenas um professor que seria escolhido, pela própria escola, para atuar no Projeto, embora a turma fosse atendida em horário integral: das $7 \mathrm{~h}$ às $15 \mathrm{~h}$, diferente das demais classes desta escola. O professor regeria a turma em caráter exclusivo e ainda atenderia a pequenos grupos, duas vezes por semana, em horário extra, das 15 às $17 \mathrm{~h}$. 
O Projeto Especial Adolescentes 2007 previa um trabalho de formação continuada e em serviço para os professores regentes. Os professores deveriam se reunir com a Equipe Gestora do Projeto todas as sextas-feiras. Neste dia os alunos deveriam ser liberados. A equipe gestora era formada por membros da Diretoria de Educação Fundamental (DEF/SME/RJ). Sua função era orientar e apoiar os professores durante o período em que o PEA estivesse em funcionamento. $O$ trabalho de formação continuada era organizado através de Centros de Estudo, com o planejamento coletivo e a organização de atividades culturais, orientadas pela equipe gestora como previsto pela Ementa do PEA (SME/RJ, 2007).

Destaca-se, ainda, que a Diretoria de Ensino Fundamental regida pelo E/DGED previa como um dos objetivos específicos do Projeto a contribuição para a atuação pedagógica dos professores regentes, em consonância com a organização dos Ciclos de Formação e o Núcleo Curricular Básico previsto pela Multieducação (SME/RJ, 1996).

O Núcleo Curricular Básico Multieducação está relacionado a uma reforma educacional que teve como objetivo central a organização curricular das escolas da SME/RJ. Em 1996, o documento do Núcleo Curricular Básico Multieducação foi encaminhado a toda Rede da SME/RJ. Os pressupostos da Multieducação, se mantém orientando as escolas da SME/RJ, apesar de algumas descontinuidades administrativas, desde a sua criação. Incluem-se nesses pressupostos "lidar com os múltiplos universos que se encontram na escola” buscando a unidade na diversidade e a necessidade constante de atualização curricular, em consonância com as Diretrizes Curriculares Nacionais que se incluíam nos Parâmetros Curriculares Nacionais (PCNs) (BRASIL, 1997) em seus Princípios Éticos, Estéticos e Políticos (SME/RJ, p. 108). 


\section{O estudo de caso do PEA na escola da rede SME/RJ}

A escola da SME/RJ que serviu de lócus da pesquisa, atendia além do PEA, turmas do Ciclo de Formação do Ensino Fundamental, da Educação Infantil e em seu prédio anexo assistia crianças órfãs através de moradia e alimentação. Em 2007, quando se deu a pesquisa de campo, a escola havia sido selecionada pela SME/RJ para receber uma das classes do PEA. Como mencionado anteriormente o horário de atendimento às classes regulares era de 4 hs em dois turnos, enquanto da classes do PEA o horário era integral e em dois dias por semana se estendia até às $17 \mathrm{hs}$.

Duas salas de aula foram objeto de observação nesta escola, uma do $1^{\circ}$ ano do $1^{\circ}$ Ciclo de aprendizagem, correspondente a Classe de Alfabetização (CA) e a outra do PEA. Os dados, objeto de análise desse capítulo, restringem-se aos coletados através da observação participante, documentos e diálogos entre a equipe de pesquisa e os atores da escola que se constituíram enquanto sujeitos da pesquisa.

$\mathrm{O}$ acesso e a permanência na escola se deu por um processo de negociação constante com a Direção da Unidade, com os professores voluntários e outros atores escolares envolvidos na pesquisa. Entre momentos de recuo e avanços nas negociações sobre como desenvolver o projeto proposto para a pesquisa, firmou-se que os instrumentos de pesquisa limitar-se-íam às observações nessas turmas CA e PEA, a coleta de materiais e documentos disponibilizados pelos professores e pela escola e conversas informais sobre temas como as classes do Ciclos e do PEA com os diversos atores escolares que se dispusessem a fazê-lo. Não foi possível, como previsto, utilizar gravadores e câmeras para a obtenção de registros em áudio e vídeo durante a realização de entrevistas, participação nos Conselhos de Classe, reuniões de pais e de professores. As visitas foram limitadas a dois membros da equipe de pesquisa, que poderiam observar as classes juntos, durante duas horas por dia, duas vezes por semana, em dias e horários previamente combinados com os professores e a direção da escola. 
O período de observação limitou-se, então, a quatro meses entre março e junho de 2007. Após esse período o estudo de campo foi interrompido, tendo em vista que o processo de colaboração entre a equipe de pesquisa e os atores escolares não se pautou pelos pressupostos estabelecidos pela equipe para o desenvolvimento da pesquisa. Isto é, a colaboração estabelecida para o desenvolvimento precisa ser produtiva para ambos e as limitações impostas por parte da escola evidenciou que isto não aconteceria.

Foram sujeitos da pesquisa um total de 67 alunos, 47 da Classe do $1^{\circ}$ Ciclo e 20 do PEA, e dois professores colaboradores, o professor do PEA, a professora da Classe de Ciclo, além de pais e responsáveis, funcionários da escola e outras pessoas que pudessem nos fornecer informações sobre os alunos e espaço do PEA e da escola. No PEA, analisado nessa pesquisa, o professor era do sexo masculino, fato relevante, pois a maioria dos regentes de turma na SME/RJ eram do sexo feminino. Considerou-se como sujeitos primários todos os participantes que contribuíram com as fontes primárias de informações para a pesquisa, isto é, os alunos. Eles são os sujeitos primários porque são capazes de fornecer dados relevantes para se compreender o objeto de estudo, a classe do PEA, dos quais são também atores primários. Considerou-se como sujeitos secundários aqueles que auxiliaram na compreensão, classificação e confirmação dos dados que diretamente informavam sobre os sujeitos primários.

A maior parte dos 20 alunos do PEA, era originária da própria escola os outros alunos, eram originários das escolas 'vizinhas'.

As questões de pesquisa que guiaram as análises realizadas para este capítulo foram: Como o PEA foi conduzido? Quem eram os sujeitos do PEA? Como era a relação da classe do PEA com as demais classes da escola? Qual era a natureza do processo pedagógico construído na classe do PEA? Como esse processo poderia contribuir para o processo de ensino aprendizagem de adolescentes em risco educacional? 
As análises foram conduzidas pelo método indutivo, tendo como premissa principal as percepções e inferências dos atores sociais participantes da pesquisa, seguida a interpretação pela equipe de pesquisa que foi subsidiada por teorias pertinentes aos temas derivados da mesmas. A triangulação dos dados foi realizada, sempre que possível, utilizando fontes distintas de dados como documentos (fichas dos alunos, projetos, lista de chamada, atividades em xerox distribuídas pelos professores), anotações derivadas das observações, conteúdo da falas dos sujeitos primários e secundários, perspectivas teóricas debatidas durante o Seminário Permanente de Pesquisa (SPP) com membros da equipe e alunos da UERJ e mapas conceituais estudados no SPP sobre o tema.

\section{A Classe do PEA: formas de organização.}

Como dito anteriormente, a Classe do PEA era a única da escola com a carga horária ampliada, de $7 \mathrm{~h}$ às $15 \mathrm{~h}$, exceto às sextas-feiras quanto os alunos eram liberados às 11:45h. Dia da semana em que o professor da turma teria que se reunir com a Equipe da SME/RJ e com os demais professores regentes de outras classes do PEA Projeto. Os objetivos dessas reuniões eram: trocar informações sobre o andamento da projeto; receber orientações; assistir palestras; debater com os colegas estratégias pedagógicas, dentre outros, etc. Nas terças e quintasfeiras a turma se dividia em dois grupos, que eram atendidos alternadamente em um horário especial, das $15 \mathrm{~h}$ às $17: 15 \mathrm{~h}$, dentro da própria sala de aula.

Os alunos dessa turma possuíam dois recreios, o primeiro coincidindo com o do Ensino Fundamental e o segundo com a saída de todas as turmas do primeiro turno. Durante os intervalos, a escola oferecia almoço e lanche.

A escola como um todo, trabalhava o currículo com os temas transversais utilizando a técnica de projetos que eram desenvolvidos ao longo do ano. A Classe de PEA adotava também essa técnica, além das estratégias do projeto pedagógico específico para o PEA (SME/RJ, 2007). 
Essa classe estava preparada para receber até trinta alunos, como consta na Ementa do PEA (2007), porém em julho de 2007, a turma possuía vinte alunos matriculados. Desses alunos, quatorze frequentava as aulas, com muitas faltas. A turma era composta mais frequentemente por sete a dez alunos. Os registros de classe demonstravam que um total de seis deles eram oriundos da própria escola. Bianca, Enzo e Edmundo eram alunos originários do $3^{\circ}$ ano do $1^{\circ}$ Ciclo e ainda não haviam completado quatorze anos, enquanto Alexandre, Tatiane, João Marcelo eram originários da Classe de Progressão de 2006 e já haviam completado quatorze e quinze anos em 2007.

A sala de aula, era bastante ampla, assim como as outras salas da escola, porém mal iluminada e úmida. As paredes da sala eram brancas, com algumas manchas redondas de terra, como se alguém tivesse chutado uma bola contra elas. Havia na sala dois ventiladores que costumavam ficar ligados durante as aulas, um de teto e outro móvel com um tripé bem alto. Também havia uma televisão e um aparelho de som que eram usados com frequência pelos alunos na hora da entrada, enquanto 0 professor esperava o restante da turma chegar e também no recreio pelos alunos que preferiam permanecer em sala. Havia também na sala, dois armários com matérias didáticos como papel, cola, tesoura, cartolinas, dicionários e mais uma estante com livros de literatura infanto-juvenil e revistas de todos os tipos, inclusive revistas masculinas.

O uso de recursos tecnológicos era previsto pelo PEA como forma de dinamizar as aulas, fazendo uso de uma linguagem diferente, mais próxima dos interesses dos adolescentes (SME/ RJ 2007). Durante as observou-se que estes aparelhos eram usados, em geral, com o objetivo de entretenimento e por iniciativa dos alunos, o professor decidia sobre o momento em que eles deveriam utilizá-los.

A organização e disposição de cada aluno em sala de aula foi um importante elemento para se notar a dinâmica e movimento de desenvolvimento do PEA, inicialmente organizada em formato tradicional, enfileiradas, com o passar do tempo 
foi reorganizada em grupo. Como demonstrado nas figuras I e II abaixo:

Figura I

Sala de aula do PEA no início da atividades em 2007

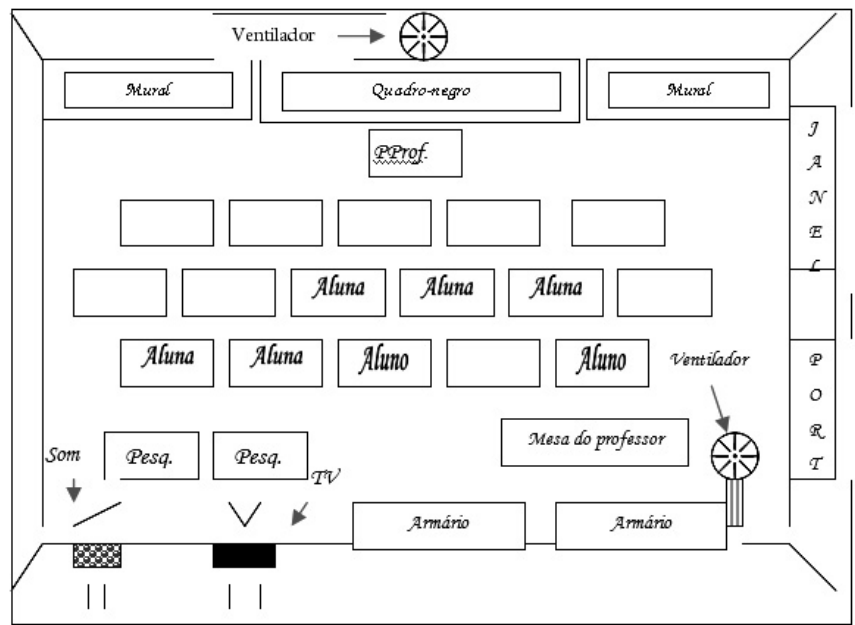

Fonte: Relatório II: Anotações de Campo do dia 16/04/2007 (FERREIRA; MATTOS, 2007).

\section{Figura II}

Sala de aula do PEA o $1^{\circ}$ mês de atividades em 2007

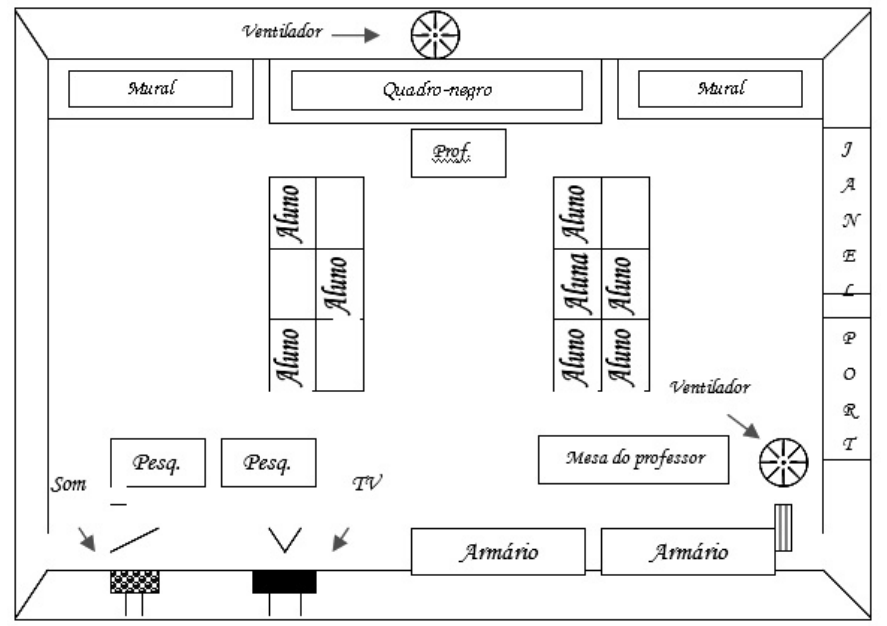

Fonte: Relatório VI: Anotações de Campo do dia 28/05/2007, (FERREIRA; MATTOS, 2007). 
Na organização, ilustrada no quadro I, os alunos sentavamse sempre a partir da segunda fileira e se agrupavam por conta própria. Nas semanas seguintes, o professor passou também a organizar as mesas dos alunos em dois grandes grupos Grupo II, alternando assim, o modelo anterior. Enquanto dava aula, o professor costumava se sentar à mesa que está mais próxima ao quadro-negro, dessa forma ele ficava voltado para a turma enquanto lia algum texto, explicava o dever ou promovia algum debate. Durante o tempo em que os alunos faziam as tarefas, ele se sentava à mesa que ficava próxima a porta. Quando se direcionava para o fundo da sala ele tinha uma visão de toda a turma enquanto aproveitava para fazer chamada, organizar seus papéis e o diário de classe.

A organização da sala no quadro I segue uma configuração tradicional onde as carteiras ficam dispostas uma atrás da outra em frete ao quadro-negro e onde o professor se posiciona em frente da turma para expor suas aulas (MATTOS; CASTRO, 2005). Nesse modelo os alunos tendem a centrar sua atenção na figura do professor. Já o quadro II indica um modelo onde a centralidade da atenção e volta para várias direções, em princípio, permite aos alunos, trocarem entre si, dúvidas e conhecimentos durante a elaboração das tarefas de aula, trabalho desenvolvido pela turma neste modelo passa então a ser realizado de modo coletivo.

No entanto, verificou-se que, em ambos modelos, a definição do espaço a ser ocupado em sala de aula pelos alunos, permitiria ao professor o controle e vigilância da movimentação dos alunos, uma vez que é o professor quem delimita a ocupação deste espaço (CASTRO, 2006).

A equipe de pesquisa sentava-se nas duas mesas ao fundo da sala de aula, o que permitia a observação de toda a turma e do professor. 


\section{A Classe do PEA: características das interações entre alunos, escola e professor-aluno.}

Para melhor entender como se dava o funcionamento da Classe do PEA é importante compreender como essa classe e os seus outros atores eram concebidos no âmbito escolar, assim como esta classe se relacionava com as demais da escola. Para isso, descrevemos algumas práticas observadas e o conteúdo do discurso existente no Projeto Político Pedagógico da Escola, dos professores, dirigentes e dos próprios alunos.

Verifica-se que a escola adotava em sua organização, modelos e práticas tradicionais comuns nas escolas públicas, isto é:

1) As salas de aula eram dispostas uma ao lado da outra até o fim do corredor, dentro delas as cadeiras estavam quase sempre enfileiradas e voltadas para quadro negro;

2) Os horários eram fracionados e delimitavam o momento em que os alunos deveriam entrar e sair da sala e da escola;

3) Todos os alunos deveriam usar o uniforme;

4) As relações estabelecidas pelos atores escolares eram permeadas por um regime de obediência hierárquica.

Para uma análise teórica buscou-se em Foucault (2002) justificativa para entender a necessidade da escola em manter procedimentos tradicionais quanto a organização física e pedagógica. Foucault (2002) afirma que a coação, o controle e a dominação pela disciplina se configuram como uma tecnologia pedagógica que atua diretamente sobre o corpo do indivíduo com o objetivo de transformá-lo em um corpo dócil (FOUCAULT, 2002, p. 127).

A Classe do PEA localizava-se ao fim de um corredor do prédio escolar, de frente para o pátio onde ocorria o recreio. Como a Educação Infantil e o Ensino Fundamental possuíam horários diferentes de recreio, o espaço o pátio era ocupado constantemente pelos alunos das outras turmas da escola. Para 
minimizar o barulho ocasionado pelos alunos em recreio, as janelas e portas da Classe do PEA permaneciam a maior parte do tempo fechadas, o que ocasionava um mau cheiro na sala, por conta da umidade. Com isso, chegamos à conclusão de que o local destinado pela escola à Classe do PEA era caracterizado pelo afastamento e pelo confinamento dos demais espaços da escola.

A chegada do PEA na escola trouxe incertezas, sobre o como e por quem esses alunos seriam atendidos, sobre como eles se encaixariam na rotina da escola no Projeto Político Pedagógico traçado para o desenvolvimento das atividades. Bauman (1999, p. 66) acredita que "na melhor das hipóteses a incerteza produz confusão e desconforto. Na pior, carregam um senso de perigo". E que a tendência mais comum de lidarmos com aquilo que é incerto é promovendo uma separação territorial e espacial, buscando reduzir a frequência desses problemas e “aliviar os aborrecimentos causados” (MATTOS, 1997).

O futuro dos alunos dessa Classe também era incerto para a escola, pois, uma vez que ela só atendia turmas até o primeiro segmento do Ensino fundamental, os alunos teriam que ser necessariamente encaminhados para outras escolas ao final do ano letivo de 2007. Inclusive os que já pertenciam à escola anteriormente.

Albuquerque (2004), acredita que os procedimentos de organização da escola são criações históricas e culturais de nosso tempo. Mas, que assim como a "síndrome dos objetos invisíveis” (GEERTZ, 2000, apud ALBUQUERQUE, 2004.) tais procedimentos estão tão obviamente diante dos nossos olhos, que é impossível encontrá-los. Ou seja, as relações estabelecidas dentro da escola são correntemente vistas como lógica e natural. Com isso, têm-se dificuldades em desnaturalizá-las e pensá-la de uma outra forma.

Uma prática da escola já bastante naturalizada é a obrigatoriedade do uso do uniforme. O uniforme pode ser considerado como sendo a tecnologia pedagógica que atua mais diretamente sobre o corpo do sujeito. Goffman (2000, p. 248), ao falar do uniforme usado nas prisões considera que "a roupa da prisão 
é anônima”. Tentando fugir do anonimato, alguns alunos da Classe do PEA tentavam imprimir sua individualidade através do uso de acessórios. As meninas usavam presilhas coloridas no cabelo, anéis, pulseiras, brincos, mochilas com chaveiros pendurados no zíper, blusinhas por baixo da camiseta do uniforme etc. Os meninos também costumavam complementar o uniforme com acessórios, e o mais usado por eles era o boné. Porém, a pedido da direção, o professor passou a proibi-los conforme pode ser ilustrado na cena abaixo:

O professor pede que Nadson tire o boné, ele então pergunta: "Porque isso agora?" o professor responde que são ordens da diretora. Nadson não obedece, o professor então pede que Enzo tire o boné. Enzo, a contragosto, acaba tirando (Relatório VI, anotações de campo do dia 28/05/2007, p.2).

Observou-se, durante a pesquisa, como era difícil a relação da Classe do PEA com a direção da escola. Não raro, o professor da Classe do PEA encaminhava alunos à secretaria pela falta de disciplina em sala de aula. Para o professor, a indisciplina se caracterizava pela desobediência às regras que ele havia estabelecido ou que foram estabelecidas em conjunto com a turma. Constituía-se como desobediência às regras: sair de sala durante a aula sem permissão, brigas, ofensas, brincadeiras fora de hora e o não cumprimento da tarefa.

Além de encaminhar os alunos desobedientes à direção, o professor também lançava mão de outras formas de punição, como mandar os alunos fazer cópias e enviar bilhetes aos responsáveis pedindo que eles comparecessem à escola:

Edmundo reclama que só recebe fora do professor e pergunta por que ele chamou sua tia na escola pra conversar. O professor responde que é porque ele já passou de todos os limites. (...) Edmundo continua preocupado com a visita de sua tia. Diz que ela ia estar lá hoje à tarde, o professor o interrompe e diz: 'Sorte sua que vai ter reunião' (Relatório IV, Anotações de campo do dia 18/05/2007, p. 2 e 4). 
Algumas vezes, a ameaça era feita sem que o professor dissesse qual castigo seria aplicado contra os alunos. O motivo pelo qual eles seriam castigados também não parecia ficar claro:

Juliana diz que está com febre, o professor manda-a ir lá fora beber água. Ela diz que não quer ir. Ele pergunta: Você vai me desobedecer?'. Ela responde que vai e ele diz: 'Então você vai ficar de castigo'. Bianca interfere: "Vem cá! Ela vai ficar de castigo só porque não quer beber água? Ai que agonia que isso me dá!' João Marcelo debocha: 'Tudo ele manda beber água!. (Relatório VI, anotações de Campo do dia 28/05/2007 p.3).

No interior da escola as ações dos alunos, do professor e da direção eram marcadas por uma relação de poder, que resultava num jogo em que um ora era oprimido, ora era opressor dentro de uma mesma lógica (FOUCAULT, 1978).

Segundo Freire (2006, p.48), essa opressão muitas vezes é mascarada por uma solidariedade que levará os oprimidos a 'serem mais', portanto, a escola ao punir o aluno desobediente às regras, estaria generosamente o disciplinando a ter um bom comportamento, ou a ter um comportamento que se espera que ele tenha. Assim, quem oprime, aos olhos dos opressores, são os oprimidos, que eles jamais obviamente chamam de oprimidos, mas de 'selvagens', 'violentos', bárbaros', 'malvados', quando reagem à violência da opressão. Freire (2006, p. 39-40) entende que a solidariedade exige de quem se solidariza que assuma a situação de com quem se solidarizou na busca pela liberdade, pois a solidariedade verdadeira implica em um agir com e não um agir para: "A liberdade é uma conquista e não uma doação, exige uma permanente busca. Busca permanente que só existe no ato de quem a faz. Ninguém tem liberdade para ser livre: pelo contrário, luta por ela precisamente porque não a tem” (p.37).

No mesmo caminho que Freire, Valle (2000, p.12) ao falar da construção da autonomia na prática educativa também se opõe ao modelo disciplinar e acrítico que a escola impõe aos alunos, explica eu ela acredita que a educação não deve ter 
como meta apenas socializar os indivíduos com base no que a sociedade institui de antemão, mas sim torná-los capaz de promover um novo modo de existência individual e coletiva.

A escola em seu Projeto Político Pedagógico, se declarava comprometida ir além do ensino de conteúdos para buscar uma construção de valores importantes à cidadania. No entanto o que ocorre no cotidiano escolar é uma prática naturalizada de coerção e de punição sem que os objetivos e os critérios fiquem claros para os alunos. O espaço para a deliberação e a legitimação dessas regras por parte dos sujeitos que a elas se impõe era restrito senão inexistente.

\section{Considerações finais}

A aproximação do contexto escolar permitiu evidenciar as regras, assim como a presença dos alunos nos classes do PEA não foram claramente compreendida pelos alunos e pela escola. Em relação a este fato Sampaio lembra que em uma escola "os alunos prejudicados têm rosto, nome, sonhos, histórias, não são números ou índices, assim como seus professores e suas professoras (SAMPAIO, 2000 p. 57). Os alunos do PEA nesta escola também o tinham mas eram como se não estivem ali, estavam resguardados, escondidos no final do corredor, numa sala de aula barulhenta e mau cheirosa em função da umidade e a proximidade com os banheiros.

Os índices do fracasso também exigem que se pense a realidade sobre quem fracassa. Quem fracassa na escola são pessoas. Essa constatação, muito longe de ser um discurso demagógico, também foi feita por Todorov (1995) - que descreveu a transformação de pessoas em não pessoas durante o regime nazista. Para ele a quantidade despersonifica e nos insensibiliza: "uma morte é uma dor, um milhão de mortos é uma informação”.

O regime escolar quase sempre é pautado pelo modelo da despersonificação, e isso ocorre de uma forma tão naturalizada que só a partir de um exercício muito grande que se consegue questioná-lo. Isso porque, na maioria das vezes, optamos pela uniformização e pela disciplina que retira, esconde o espaço da diversidade da diferença. 
O questionamento a esse regime, no entanto, revela que ele parece estar permanentemente contra o aluno e que alcançar o sucesso, significa vencer o sistema que a todo instante tenta empurra-lo para fora. A justificativa para a seleção promovida pela escola para a formação do grupo de alunos que se constituiu a classe do PEA, encontra respaldo na forma que para a sociedade significaria o sucesso, para ter sucesso é preciso enfrentar as barreiras, superar o outro o diferente. Portanto, dentro da escola o sucesso não é para muitos, assim como dentro da sociedade também não será, visto que no topo não há lugar para todos.

A reprovação, quase sempre esteve, aliada ao processo de exclusão, chegando a ser considerada uma prova de qualidade da escola e do professor. O bom professor era aquele que não 'deixava fácil', que reprovava até por décimos.

Por outro lado, quanto ao aluno a reprovação sempre esteve contra, sendo sinal de incompetência, incapacidade, preguiça etc. E por mais que ele ‘aprendesse a lição’ e não repetisse mais, ele ia carregar esse ano de atraso por toda a carreira escolar como uma marca de fracasso.

Com isso, a retirada da reprovação e a chegada dos Ciclos de Formação foi recebida tanto pela escola, quanto pela sociedade como o anúncio do caos. A escola que estava pautada na aprendizagem pelo medo da avaliação, da nota, da repetência e da humilhação, viu-se abalada.

A luta para a democratização ao acesso à escola exige uma transformação no sentido da educação por toda a sociedade, pois ela vai de encontro ao já naturalizado pensamento de que o acesso ao conhecimento é para poucos. Ou seja, frequentar a escola e avançar com sucesso é privilégio para apenas os que são fortes e determinados o suficiente ou que já recebem de herança familiar esse direito.

A democratização do acesso ao ensino ainda é um primeiro passo para que seja possível vislumbrar uma sociedade menos desigual, onde todos tenham consequentemente as mesmas possibilidades de acesso ao trabalho. 
Dentro da escola existe uma forte cultura que restringe o acesso ao saber. Mesmo com a implantação dos Ciclos, que no caso do Rio de Janeiro substituiu a reprovação do primeiro segmento do ensino fundamental até 2006 por relatórios de avaliação de progressão automática, embora as escolas continuassem a utilizar o modelo antigo retardando a reprovação para o final do $1^{\circ}$ segmento do Ciclo ou reprovando o aluno consecutivamente na Classe de Progressão, práticas que refletiram em parte na eliminação da mesma.

O fim da Progressão e a ampliação dos Ciclos em todo o ensino fundamental revelou que havia um contingente de alunos com idade entre quatorze e quinze anos que ainda não haviam passado do primeiro segmento, ou seja, ainda não tinha se quer sido se quer alfabetizado ou letrado de modo a poder dar continuidade aos estudos em outro nível.

O encontro com esses alunos na Classe do PEA possibilitado pela pesquisa, permitiu aos membros da equipe de pesquisa, entender um pouco mais como essa exclusão acontece dentro do espaço de sala de aula. O PEA que foi planejado para auxiliar o aluno, oferecendo uma maneira diferenciada de acompanhamento escolar com horário ampliado, formação continuada para o professor, dentre outros, acabou por encontrar os diversos entraves dentro da escola, que o levaram a reproduzir as mesmas práticas já naturalizadas no ambiente escolar, levando este aluno mais uma vez os alunos ao fracasso.

A falta de credibilidade no PEA e dos alunos que frequentavam esta classe, foi visível por parte da direção da escola e se refletiu na forma com que a Classe foi recebida por ela. Ela não só separou fisicamente a mesma das outras classes da escola, como ainda atribui a regência da Classe, por coincidência ou não, a um professor do sexo masculino, recém chegado o que para este representou uma 'prova de fogo' para sua entrada na rede pública de ensino.

Para Neubauer (2001), os Ciclos desvelam a incompetência da escola e do sistema em ensinar que a reprovação mascarava. Ele não permite mais que a punição seja unilateral e impede a farsa onde o professor "finge que ensina e o aluno 
não aprende porque não é capaz, pois no sistema de Ciclos a marca do fracasso não é mais do aluno, é da escola. Com isso, os Ciclos exigem o trabalho coletivo da escola para garantir o sucesso dos alunos, pois "a cada final de ano, ou o aluno conseguiu avançar mais, aprender, ou foi a escola que ficou para trás” (p. 10).

O movimento para a transformação que a autora afirma ocorra, advém de um processo lento das escolas. Professore, alunos e pais, lamentaram-se pelo fim da retenção, e continuaram a associar os baixos desempenhos dos alunos à retirada do estímulo que a possibilidade da reprovação garantia. No entanto, alguns estudos (WALLON, 1989; FREIRE, 2005; FERREIRO, 1995), já propunham um modelo escolar a favor da aprendizagem do aluno através de outros tipos de estímulos, como a valorização do saberes trazidos por eles, a atenção às suas curiosidades, entre outros, baseando-se em valores que permitem a troca, o respeito e a construção da autonomia do aluno.

A educação no país parece caminhar para significativas mudanças que, em grande parte, são conquistas de longas lutas impulsionadas principalmente por educadores progressistas, que através de seus trabalhos ou de sua capacidade de mobilizar a sociedade civil, conseguiram alcançar algumas melhorias nas Leis que regem a educação. No entanto, como a história educacional no Brasil é marcada por avanços e retrocessos, os Ciclos, assim como outras iniciativas tomadas como inovadoras, podem acabar se tornando apenas mais uma tentativa fracassada para que a democratização da educação aconteça. Neste sentido torna-se fundamental que haja uma compreensão desse tipo de proposta e a aprendizagem de uma postura sensível entre os profissionais da educação e o público em geral sobre o papel da escola nestas propostas. 


\section{Referências}

ANDRÉ, M. D. A. de. Estudo de caso em pesquisa e avaliação educacional. Brasília: Líber Livro, 2005.

ALBUQUERQUE, A. E. M. de. Educação e autoritarismo, por uma gestão democrática do espaço escolar. Revista Linhas Críticas, UnB, vol. 10, n. 18, p.33-48, jan./jun., 2004.

BAGNO, M. A Norma Oculta: língua \& poder na sociedade brasileira. $2^{a}$ ed. São Paulo: Parábola, 2003.

BAUMAN, Z. Modernidade e ambivalência. Rio de Janeiro: Jorge Zahar, 1999.

BRASIL. Lei de Diretrizes e Bases da Educação Nacional. Ministério da Educação: Brasília, DF. Disponível em:< http://portal.mec.gov.br/arquivos/pdf/ldb.pdf>. Acesso em: 14 junho 2008.

CARVALHO, M. P. de. Quem são os meninos que fracassam na escola? Cadernos de Pesquisa, v. 34, n. 121, p. 11-40, jan./abr., 2004.

CASTRO, P. A de. Controlar para quê? Um análise etnográfica da interação entre professor e aluno da sala de aula. 187f. 2006. Dissertação (Mestrado em Educação) - Faculdade de Educação, Universidade do Estado do Rio de Janeiro, Rio de Janeiro, 2006.

FAGUNDES, T. B. Fracasso Escolar: um estudo etnográfico em uma classe de progressão na rede pública do Rio de Janeiro. 2007. 84f. Monografia (Graduação em Pedagogia) - Faculdade de Educação, Departamento de estudos aplicados ao ensino, Universidade do Estado do Rio de Janeiro, Rio de Janeiro, 2007.

FERREIRO, E. Desenvolvimento da Alfabetização: psicogênese. In: GOODMAN, Y. M. (org). Como as crianças constroem a leitura e a escrita: perspectivas piagetianas. Porto Alegre: Artes Médicas, 1995.

FREIRE, P. Pedagogia do Oprimido. Rio de Janeiro, Paz e Terra, 2005. 
FOUCAULT, M. Microfísica do Poder. 25 ed. Rio de Janeiro: Edições Graal, 1979.

FOUCAULT, M. Vigiar e punir: nascimento da prisão. 26. ed. Petrópolis: Vozes, 2002.

GEERTZ, C. A interpretação das culturas. Rio de Janeiro: LTC, 1989.

GOFFMAN, E. Manicômios prisões e conventos. 7. ed. São Paulo: Perspectiva, 2001.

HAMMERSLEY, M.; ATKINSON, P. Ethnography: principles in practice. London: Routledge, 1983.

MATTOS, C. L. G de. Imagens etnográficas da inclusão: o fracasso escolar na perspectiva do aluno. Relatório de pesquisa Prociência (2005-2008). Universidade do Estado do Rio de Janeiro, 2008.

MATTOS, C. L. G. de; ALMEIDA, S. M. de; MELO, S. C de. O espaço da exclusão: o limite do corpo na sala de aula. Anais da Reunião Anual da ANPED, Caxambu - MG,1997.

MATTOS, C. L. G.; CASTRO, P. A. de. O uso de imagens de vídeo na pesquisa etnográfica. Anais IV Encontro de Pesquisa em Educação no Brasil / Região Sudeste - Educação: Direito ou Serviço? Belo Horizonte, 2005.

NEUBAUER, R. Quem tem medo da progressão continuada? Ou melhor, a quem interessa o sistema de reprovação e exclusão social? Publicação: Artigo da Secretaria Estadual de Educação, São Paulo, 2001. Disponível em: <http://www.centrofeducacional.com.br/progrcont.htm>. Acesso em: 14 junho 2008.

SME/RJ. Multieducação: refletindo sobre o trabalho no $1^{\circ}$ Ciclo de Formação. 2.ed. Secretaria Municipal de Educação do Rio de Janeiro Rio de Janeiro, Série: A Multieducação na Sala de Aula. 2007a. 
SME/RJ. Secretaria Municipal de Educação. Formação em Serviço para Professores Regentes do Projeto Especial Adolescentes 2007. Secretaria Municipal de Educação do Rio de Janeiro. Departamento Geral de Educação: Rio de Janeiro, 2007b.

SME/RJ. Secretaria Municipal de Educação. Os Ciclos do Ensino Fundamental, Aspectos Históricos, Políticos e Pedagógicos. Indicação n. ${ }^{\circ} 3 / 2007$. Secretaria Municipal de Educação do Rio de Janeiro: Rio de Janeiro, 2007c Disponível em: <http://www.rio. rj.gov.br/sme/downloads/cme/indicacao3.doc>. Acesso em: 16 junho 2008.

SAMPAIO, M. das M. F. Aceleração de Estudos: uma intervenção pedagógica. Em Aberto, Brasília v. 1, n.71, p. 57-73, jan. 2000.

TODOROV,T. Em face do extremo. Campinas: Papirus, 1995.

VALLE, L. do. Ensino de Filosofia - Perspectivas. Belo Horizonte: Autêntica, 2002.

WALLON, H. Origens do pensamento na criança. São Paulo: Nova Alexandria, 1989

SME/RJ. Núcleo Curricular Básico Multieducação. Secretaria Municipal de Educação do Rio de Janeiro. MULTIRIO: Rio de Janeiro,1996. 


\title{
Violência na escola: reconstruindo e revisitando trajetórias e imagens de pesquisas produzidas por no Núcleo de Etnografia em Educação entre 1992 e 2007.
}

\author{
Carmen Lúcia Guimarães de Mattos \\ Maria Inês de Matos Coelho
}

Este capítulo aborda a violência na escola. O aporte teórico de embasamento do mesmo delineou-se partir de revisão de literatura sobre o conceito violência, de vinhetas etnográficas derivadas de artigos produzidos entre 1992 e 2007 pelo Núcleo de Etnografia em Educação (netEDU) da Universidade do Estado do Rio de Janeiro (UERJ) e de imagens de vídeos revisitadas por Coelho (2008) originárias de pesquisa coordenada por Mattos (2005-2008). As imagens registradas em vídeo envolvem o conjunto de dados das pesquisas de Mattos $(1992,1996,2008)$ e Castro (2006).

Presença constante nos noticiários da televisão e da imprensa, a violência se impõe como realidade de crueldade e de insensibilidade, com muitas faces: a familiar, a ligada ao tráfico de drogas, a do cotidiano dos centros urbanos, a institucional, aquela que envolve pessoas próximas ou desconhecidas. O tema violência se impôs aos demais observados e registrados e mereceu análise particular não somente pelas implicações que contém para as práticas escolares, como no âmbito conceitual para delimitar aspectos e interfaces entre a violência social como um todo e a escolar.

Horror, espanto, preocupação, insegurança são reações que se colam a sociedade frente aos sentimentos de revolta, impotência e medo (WERTHEIN, 2000; UNESCO, 2001; WAISELFSZ, 
2002). Na escola este sentimento amplia-se e mistura-se ao cenário escolar, muitas vezes impedindo a paz e a liberdade dos alunos e alimentando um sentimento de impotência e naturalização das relações intra-escolares.

\section{Conceito de Violência e a violência na escola}

Arendt descreve a violência no século XX, explicada pela frustração da faculdade de agir no mundo contemporâneo, que tem suas raízes na burocratização da vida pública, na vulnerabilidade dos grandes sistemas, que secam as possibilidades de criação (ARENDT, 1969, p. 8-14). A autora traz uma distinção polêmica, mas também original, entre poder e violência. Considera que o poder é mais ligado à capacidade de agir em conjunto, inerente a qualquer comunidade política. Para Arendt é na desintegração do poder que a violência se apresenta multiplicando o 'vigor individual'.

Portanto, a violência não pode ser identificada a uma essência a qual o homem estaria necessariamente aprisionado (FREIRE COSTA, 1984, p.34).

Embora a natureza e as dimensões reais do fenômeno da violência ainda não estejam suficientemente esclarecidas, já se compreende alguns dos seus impactos na vida e nas práticas sociais das pessoas e, ainda, como a disposição para atos violentos e o risco da vitimização estão ligados aos contextos social, cultural e econômico. Também já se tem clareza de que a educação é o caminho principal para prevenção e combate à violência. No entanto, paradoxalmente, essa violência se faz presente cada vez mais nas instituições escolares nas quais assume várias formas. Neste paradoxo encontram-se as reflexões quanto às relações entre 'violência e sociedade', neste contexto, de um lado fica a 'violência e do outro a educação' (PINO, 2007).

Charlot (2002, p. 432-433) assinala que, historicamente, a questão da violência na escola não é tão nova tendo sido registrada ainda no final do século XIX. As formas que ela assume é que são novas, sendo importante considerar a violência na 
escola ou que se produz dentro do espaço escolar sem estar ligada à natureza das atividades de ensino, diferente da violência contra a escola, que visa atingir a instituição e aqueles que a representam, e também distinta da violência da escola, institucional, simbólica e que incide sobre os estudantes via imposição curricular, modos de organização das classes, avaliação autoritária e outras formas de controle, discriminação e humilhação. Neste texto aborda-se a violência na escola como abrangendo as três modalidades mas, principalmente, as ações violentas da escola como instituição e os atos contra a escola. Portanto, a temática da violência na escola constitui um desafio que se impõe e do qual não se pode escapar quando se pretende contribuir para subsidiar a discussão de questões relativas à realidade da Escola Básica com a finalidade de construir alternativas para a melhoria do ensino público e a formação de professores.

Alguns eixos principais tensionam a questão da violência na escola. Um deles refere-se ao sentimento de vitimação e à exposição ao risco da violência que são socialmente desiguais e correlatos à exclusão social e escolar. Nesse sentido, uma importante ligação entre violência e exclusão interna pela prática escolar, frequentemente oculta, na organização do ensino, em escolhas e percursos de formação profissional e em aspectos étnicos, é esclarecida por meio de longa pesquisa etnográfica na França que foi desenvolvida por Payet (1997, apud DEBARBIEUX, 2001, p.180-181).

Outro eixo importante nos convida a considerar como dimensões da violência, não apenas a transferência de padrões sociais externos para o espaço escolar mas também as relações interpessoais nesse espaço.

Desse modo, temos que entender a violência como relação de sociabilidade presente na escola, trazida ao espaço escolar por uma dupla fonte: ou como expressão de um autoritarismo pedagógico ou como transferência de uma norma social. A primeira, afirmando uma fórmula repressiva de conduta professoral na sala de aula; a segunda, marcada 
pela violência que rege as relações interpessoais em grupos sociais particulares, as quais se manifestam como normalidade no cotidiano dos alunos e de suas famílias e, por este entendimento, esta violência doméstica se transfere para o espaço escolar (TAVARES DOS SANTOS, 2001, p.115).

Supomos que a violência não se reduz àqueles atos violentos visíveis aos nossos olhos, como também se esconde em ações silenciadoras, discriminadoras, de desrespeito e de humilhação, nem sempre reconhecidas como violentas. No entanto, deixam marcas e influenciam no desenvolvimento da individualidade de cada um dos sujeitos, seja como vítimas ou como agentes e praticantes. Supomos também que, nas práticas de violência escolar, docentes e alunos se antagonizam, se posicionam em disputa ou luta por autoridade, disciplina e autonomia. Em lugar de educar e de ensinar e aprender, essas relações na escola acabam por desumanizar. Como Paulo Freire (1987) já tinha-nos advertido, os processos de humanização vêm historicamente acompanhados de processos de desumanização. Ainda pouco estudados, esses processos desafiam-nos para reflexão e ação.

Considerando-se que a instituição escolar se inscreve na ordem da linguagem e da troca simbólica e não da força física, é a violência enquanto vontade de destruir, de aviltar, de atormentar, que causa mais problema. Concretamente, isso significa que a agressividade e o conflito podem ser regulados pela palavra e não pela violência e assim, podem assumir formas legítimas e aceitáveis. não deve ser enunciada somente em relação aos alunos. O problema da violência na escola deixa de ser visto como apenas dos alunos e passa a ser também da escola, pois “o que está em jogo é também a capacidade de a escola e seus agentes suportarem e gerarem situações conflituosas, sem esmagar os alunos sob o peso da violência institucional e simbólica” (CHARLOT, 2002, p. 436).

Este texto busca refletir sobre a violência na escola, colocando o foco nas relações em sala de aula considerando os sujeitos de ensinar e de aprender. Algumas questões nos desafiam: 
Como investigar a violência na escola considerando as relações de sociabilidade e as especificidades que essas tem para os sujeitos? Como, e em que cenas etnográficas, a violência está registrada em processos interacionais, em salas de aulas? Como a violência se manifesta na relação entre sujeitos, de ensinar e de aprender? Como professora e alunos se relacionam e convivem no jogo de autoridade e disciplina? Como as categorias de violência identificadas e descritas em processos interacionais, em salas de aulas, se relacionam com categorias referenciais identificadas a partir de revisão de literatura da temática? Quais concepções de infância e adolescência se expressam na sala de aula e como significam reconhecimento ou não dos educandos como sujeitos de direitos e como sujeitos de cultura?

Violência na escola apresenta-se como difícil de definir pois, não somente remete aos "fenômenos heterogêneos, difíceis de delimitar e de ordenar”, mas também desestrutura as "representações sociais que têm valor fundador: aquela da infância (inocência), a da escola (refúgio de paz) e a da própria sociedade, pacificada no regime democrático" (CHARLOT; EMIN, 1997, p.1). Além disso, o significado de violência não é consensual e varia em função do estabelecimento escolar, do status de quem fala (professor, diretor, aluno, etc.), da idade e, provavelmente, do sexo.

Ao longo de mais de trinta anos, muitos estudos vêm sendo realizados e têm desvelado como crianças, adolescentes e jovens são vítimas de diferentes formas de violência bem como se envolvem em práticas de violência vivenciadas na escola e fora dela. Também vêm sendo construídos novos referenciais teóricos para interpretar a complexa relação das violências com aspectos sociais e econômicos. Esse conjunto diferenciado de pesquisas indica não só que o problema da violência existe, mas que ele é complexo, multifacetado, ambíguo e polissêmico (CHESNAIS, 1981, MAFFESOLI, 1987, SPOSITO, 1994; DEBARBIEUX, 1996, 2001; CHARLOT; EMIN, 1997).

Os impactos da violência sobre a aprendizagem e o fracasso escolar e sobre o funcionamento da escola têm sido apontados em vários estudos como os de Mattos (2007), Candau et. 
al. (1999), Tavares dos Santos (2001); Abramovay e Avancini (2003). Vêm sendo cada vez mais abordados nas pesquisas da temática, os processos tangenciados pela violência. na socialização (DUBET, 1992), na formação ética identitária e cultural e no desenvolvimento humano de educandos (FOUCAULT, 1985, 1994; MATURANA, 2000, ARENDT, 1961) No entanto, os impactos da violência no bojo de processos de desumanização ainda estão sendo muito pouco discutidos.

Um marco importante na elucidação da violência na escola encontra-se no famoso livro A reprodução, editado no Brasil em 1975, em que Bourdieu e Passeron desenvolvem a concepção de violência simbólica nos vínculos com o poder simbólico e a reprodução social e cultural. O poder simbólico é poder subordinado, uma forma transformada, quer dizer, irreconhecível, transfigurada e legitimada das outras formas de poder. Define-se como:

poder de constituir o dado pela enunciação, de fazer ver e fazer crer, de confirmar ou de transformar a visão do mundo e, deste modo, a ação sobre o mundo; poder quase mágico que permite obter o equivalente daquilo que é obtido pela força (física ou econômica), graças ao efeito específico de mobilização, só se exerce se for reconhecido, quer dizer, ignorado como arbitrário (BOURDIEU, 1989, p.15).

Dissimulação e transfiguração das relações de força, numa relação determinada e, por meio dessa, entre os que exercem o poder e os que lhes estão sujeitos, é que possibilitam fazer com que seja ignorada a violência que elas encerram objetivamente. Embora essa concepção de violência associada ao poder simbólico tenha orientado muitos estudos sobre a relação entre sociedade e escolarização, o problema da violência na escola emerge mais claramente e passa a ser estudado no bojo das reformas de democratização do acesso à escola.

Somente nos anos 90 é que a violência na escola aparece, na produção sociológica, como um objeto digno de ser pensado por si mesmo. Assim Debarbieux (2001, p.185) conclui numa 
revisão dos estudos acerca da violência na escola francesa, no período de 1967 a 1997.

Em trinta anos, o objeto "violência na escola" ampliou-se consideravelmente. Inicialmente dimensão oculta das bagunças tradicionalmente reguladoras, a violência dos alunos apareceu como resultado da mutação profunda do sistema escolar, que acolhia novos públicos, menos favorecidos, e faz subitamente perceptível sua desigualdade fundamental, malgrado suas promessas de igualitarismo republicano.

No Brasil, no início dos anos 80 o debate já havia se iniciado em torno de alguns estudos de caso que, segundo Abramovay e Avancini (2003, p.9), teve continuidade com o refinamento do conceito de violência, considerando a população-alvo - os jovens - e o lugar social da instituição-objeto - a escola. Na produção acadêmica de duas décadas, a violência não é apenas física mas também simbólica, envolvendo referenciais éticos e políticos.

[...] os autores não contemplam apenas a violência física, mas enfatizam a ética e a política, além de se preocuparem em dar visibilidade às "violências simbólicas". Por exemplo, encontram um nexo entre a violência e a quebra do diálogo, da capacidade de negociação - que é a matéria prima do conhecimento/educação. Assim, violência é todo ato que implica a ruptura de um nexo social pelo uso da força. Nega-se, assim, a possibilidade de relação social que se instala pela comunicação, pelo uso da palavra, pelo diálogo e pelo conflito (ABRAMOVAY; AVANCINI, 2003, p.9).

É importante lembrar que a reforma do ensino de $1^{\circ} \mathrm{Grau}$, em 1971, previu a expansão da escolaridade para oito anos, na perspectiva da democratização do acesso à escola básica. A implantação dessa reforma possibilitou a entrada da infância-adolescência populares na escola pública. No entanto, essa escola não se reconfigurou em sua função pública diante da diversidade e da desigualdade e as estatísticas de reprovação revelaram (e continuam ainda revelando) o fracasso imposto, 
por suposta incapacidade cognitiva, às crianças e aos adolescentes populares, pobres e negros. Na década de 80 , segundo Abramovay e Avancini (2003), prevaleciam as ações contra o patrimônio, tais como as depredações e as pichações, que hoje são muito investigadas e, mas já nos anos 90 ganham destaque as formas de agressão interpessoal, principalmente entre os alunos conhecidas como bullying. Nos estudos analisados assim como nos estudos de Sposito (1998, 2001), salienta-se o papel das desigualdades sociais como 'potencializadoras da violência', a preocupação com a banalização da violência, e ainda, o silêncio em relação às violências ou o modo como são definidas.

Há vários tipos de manifestação de violência nas escolas brasileiras, como demonstram os resultados de pesquisa de Abramovay e Rua (2002) e de Abramovay e Avancini (2003). Foi adotada a expressão 'violências nas escolas', segundo as autoras para 'dar conta da pluralidade de dimensões envolvidas no fenômeno da violência' e para 'situar o fenômeno não em um sistema institucional, genericamente considerado, pois contempla a especificidade espacial e temporal de cada uma das suas unidades'. Abramovay e Avancini utilizam em suas pesquisas duas definições de violência:

(1) Intervenção física de um indivíduo ou grupo contra a integridade de outro(s) ou de grupo(s) e também contra si mesmo, abrangendo desde os suicídios, espancamentos de vários tipos, roubos, assaltos e homicídios até a violência no trânsito, (disfarçada sob a denominação de "acidentes"), além das diversas formas de agressão sexual. (2) Formas de violência simbólica (abuso do poder baseado no consentimento que se estabelece e se impõe mediante o uso de símbolos de autoridade); verbal; e institucional (marginalização, discriminação e práticas de assujeitamento utilizadas por instituições diversas que instrumentalizam estratégias de poder) (ABRAMOVAY; AVANCINI, 2003, p. 15).

Um quadro complexo em que a violência tem impacto sobre a aprendizagem foi delineado pela pesquisa "Violências nas Escolas”, da UNESCO, cujos resultados foram divulgados em 
2002 Esse estudo (WAISELFSZ, 2002), realizado em 13 capitais brasileiras e no Distrito Federal, demonstra que as situações de violência repercutem sobre a aprendizagem e a qualidade de ensino tanto para alunos como para professores. De modo geral, os impactos mais significativos das violências são, pela ordem, alterar o ambiente da escola, tornando-o mais pesado, provocar ausência às aulas e piorar a qualidade das aulas. No que diz respeito ao clima escolar, $44 \%$ dos alunos sustentam que as violências dificultam a concentração nos estudos. Em segundo lugar, estão os estudantes que dizem que ficam nervosos, revoltados, com as situações de violência na sua escola: $31 \%$. A terceira consequência mais citada pelos alunos é a perda de vontade de ir à escola, a qual foi mencionada por $31,4 \%$ dos estudantes. Como já apontado, uma parcela significativa de alunos e de docentes afirmam que deixa de comparecer às aulas em decorrência da violência no ambiente escolar. Cerca de $7 \%$ dos alunos diz que faltam às aulas por causa da violência. Entre os professores, a proporção é de $2,6 \%$. No que se refere aos membros do corpo técnico-pedagógico, são mencionados três tipos de consequências: a perda de estímulo para o trabalho (47,5\%); o sentimento de revolta (28,3\%); a perda de vontade de trabalhar (24,2\%).

É importante considerar que a violência não é fenômeno homogêneo, nem em suas manifestações nem em seus significados. Considerando a violência de jovens, Dubet (1992) delineia quatro categorias em processos sociais específicos, cada uma tendo diferentes fatores e significados. O primeiro tipo é a violência "normal" e tolerada que tem se tornado mais grave à medida que não está mais enraizada em regulações tradicionais, na família, nas comunidades e na escola. A segunda categoria aparece face à sociedade fracionada, em que o jovem defende seu 'território' e cria 'microsociedades' como reação à desorganização social. A terceira forma é a delinquência 'utilitária' para reduzir as tensões do insucesso escolar, da falta de emprego, do racismo, da competitividade e da imposição do consumo. A quarta categoria é violência da 'revolta', 'raiva' mesmo, porque os sentimentos de dominação e de exclusão não dispõem de canais ideológicos e de meios institucionais que lhes dê forma. Cada uma dessas categorias resulta em diferentes reações e precisa ser interpretada diferentemente. 


\section{Imagens da violência na escola}

As análise desenvolvidas para subsidiar a reflexão sobre como a violência na escola que se traduz neste capítulo, se insere nos processos de fracasso escolar e de exclusão, num jogo de oponentes entre a autoridade docente e a disciplina (disciplinamento/controle) dos alunos. Nesse sentido, em primeiro lugar, reviu-se os estudos pertinentes de forma a clarificar a complexidade da violência na escola e algumas categorias teóricas. Em seguida, descreveu-se algumas cenas ou vinhetas etnográficas de violência em processos interacionais, em salas de aulas, realizando-se a análise de como as categorias indutivas dessas cenas se relacionam com categorias referenciais identificadas a partir de revisão de literatura da temática.

Deste modo, algumas vinhetas etnográficas de processos interacionais, em salas de aulas, com registros de cenas de violência que forma colocadas em primeiro plano de análise, observando-se a sequência completa de cada cena confrontando-se anotações de campo e informes de observadores, para identificação, seleção bem como de esboço de categorização indutiva de cenas de violência.

As análises sobre imagens de violência na escola derivaram de processos interacionais registrados em salas de aulas. Elas foram pesquisadas em três momentos de pesquisa (MATTOS, 2007). O primeiro se deu no período entre 1989 e 1992 (MATTOS, 1992) e teve como objeto a diversidade de explicações de dificuldades educacionais entre estudantes de escola urbana e rural. O segundo entre 1992 e 1996 (MATTOS, 1996) foi realizada como um desdobramento da primeira pesquisa, considerando os alunos fracassados no interior da escola. $O$ terceiro, entre 2005 e 2008 (MATTOS, 2008). Este texto retoma tema fracasso escolar, após duas décadas. Em 2004 os vídeos do trabalho de campo por Castro (2006) resultaram análise que também abordam o tema violência na escola, via controle do comportamento do aluno. A autora utiliza, dentre outros estudos, o trabalho de Foucault (1987) sobre o controle dos corpos para realizar suas análises. 
Uma das contribuições principais desses três momentos dos estudos apontados, é a utilização da abordagem etnográfica de alunos excluídos e repetentes dando-lhes voz e explicitando seu diálogo com outros participantes. Ao buscar determinar as razões do fracasso escolar, procura-se descrever parte do saber popular que perpetua as imagens dos jovens como sendo delinquentes e descuidados (MATTOS, 2005). O estudo da interação em sala de aula tem sido possível, com o uso de técnicas microetnográficas, utilizando o potencial de vídeo para coletar e analisar dados. Para cada segmento de uma aula de $40 \mathrm{~min}$, foi realizada uma análise detalhada. Considerando o conjunto de principais cenas de processos interacionais, em salas de aulas, já gravadas de 1992 a 2007, em escolas públicas de ensino fundamental no Rio de Janeiro, cenas foram selecionadas confrontando-se anotações de campo e informes de observadores, para identificação como de esboço de categorização indutiva de cenas de violência.

Para fins de apresentação neste capítulo, foram selecionadas imagens etnográficas, que descrevem as duas categorias indutivas a seguir:

a) a violência institucional 'espaço de segregação', 'ironia' e 'dever';

b) a violência na escola 'tirando a cadeira' e 'brigas'.

\section{Violência institucional: o 'espaço de segregação'}

Iniciamos com a observação e filmagem de uma classe de quarta série, em escola urbana, realizada em 1993 (MATTOS, 1996). Foi observada a sala de aula fisicamente; media seis de largura por seis de comprimento, as carteiras estavam dispostas em grupos de quatro, o que não significava trabalho grupal, pois os quarenta e dois alunos trabalham quase que regularmente de modo individual. Em entrevista com a professora ela revelou que, no contexto da sala de aula existiam dois tipos de alunos que recebiam a atenção dela de forma distinta: o primeiro, o grupo ‘dos melhores' era minoria, pois eram os alunos que não estavam defasados na série ou tinham 
pequena defasagem . O segundo era o grupo dos 'piores' onde se incluíam aqueles com maior defasagem em relação à série. Enquanto o primeiro grupo recebia atenção e disponibilidade da professora, o segundo recebia indiferença. A professora disse que esses eram alunos que não 'mereciam' serem trabalhados pois não renderiam muita coisa no final do ano, e era 'perda de tempo'.

Usado como instrumento de controle disciplinar ou critério avaliativo para determinar o sucesso ou fracasso dos alunos, o espaço de segregação constitui uma violência. Existia uma interdependência entre o limite do corpo (espaço que o aluno ocupava) e a identidade social desses alunos como membro do grupo constituído da sala de aula (bom ou mau aluno). Assim as práticas nesse espaço levavam os educandos ao estigma de maus alunos, esse era o espaço da exclusão. Nessa sala de aula. Nessa pesquisa certificamos de que esse espaço da exclusão era comum em muitas salas de aula onde o aluno com problemas de aprendizagem existe.

\section{Violência institucional: a 'ironia'}

Na mesma classe de quarta série, em escola urbana, realizada em 1993 (MATTOS, 1994b; 1996), a professora usava um estilo irônico como estratégia de aula Embora essa prática fosse caracterizada por ela como uma 'parte de sua personalidade', tinha como efeito diminuir a autoestima dos alunos e desviá-los dos conteúdos necessários para a superação de suas necessidades educacionais imediatas que, no caso, se caracterizavam principalmente pela superação do estigma do fracasso. Esse estilo - a ironia- promovia a marginalização dos alunos, pois desinteressados por esta batalha constante e, desmotivados pelo ‘silêncio' da não participação em sala de aula, acabavam por 'se excluírem' das escolas. Mesmo sendo utilizada pela maioria dos professores, que atuam com jovens com dificuldades de aprendizagens a prática do uso da ironia em sala de aula , com o intuito de chamar a atenção dos mesmos, é um recurso que, em muitos casos, como o que foi estudado, leva a dificultar a interação de sala de aula. 
No âmbito das análises sobre a sala de aula, a construção do fracasso ficava evidente. As relações baseadas em ironia, desrespeito e indefinição de tarefas eram de a uma verdadeira batalha entre professores e alunos. Como resultado, o aluno era levado ao fracasso, na maioria das vezes, por não querer fazer parte daquele jogo incompreensível que era a relação professora e aluno, outras vezes por encontrarem naquela relação a natureza de suas próprias dificuldades. Sendo ele estigmatizado como incapaz acabava por acreditar no fato e desempenhar esse papel, até para agradar a professora.

\section{Violência institucional: o 'dever'}

Na situação que descreveremos abaixo, a interação verbal da professora com a classe limitou-se a momentos em que pedia silêncio aos alunos (MATTOS, 1996) . Enquanto as crianças desenvolviam a tarefa a professora andou entre as carteiras parando ocasionalmente perto de uma criança e falando:

Tá tudo errado! Conta direito! Já acabou a tabuada ? Senta direito! Cala a boca! Tá tudo errado!

A tarefa na qual a turma estava trabalhando envolvia copiar texto do livro (cartilha) e escrever números. Alguns alunos estavam escrevendo números em uma sequência regular; de 1 a 150 , de 150 a 200 e de 200 a 300. A professora andava constantemente entre as carteiras dos alunos, olhando, impacientemente, para o trabalho dos mesmos e ‘ajudando' àqueles que demonstravam dificuldades. A professora escreveu a tarefa no quadro e no caderno de cada criança, sem dar explicações verbais sobre o que deveria ser feito. Na maior parte do tempo, tarefas diferentes daquelas que ela escreveu no quadro eram pedidas aos alunos através de tarefas escritas por ela nos cadernos. O objetivo das tarefas não parecia estar claro para os alunos nem para a professora. Ela pediu para os alunos completarem as tarefas porque seriam parte da nota final. Esta foi a 'explicação' dada pela professora à turma toda: 
- Olha, essa nota aí vo... vocês fizeram uma avaliação ontem. Um exercício valendo nota, não foi?! Mas com esse exercício daí mais com o que tá na secretaria. Vou dividir por 3 a nota! (Uma menina da frente entorta a boca dizendo "Ih, que coisa chata!").

Interpretando o que foi dito, a mensagem era que os exercícios eram uma espécie de 'teste' cuja nota, deveria ser somada à nota final ao término do período de recuperação. Porém a professora disse que aquelas crianças seriam repetentes para o próximo ano, e que, não importava a nota que conseguissem. Assim a tarefa era feita para "matar o tempo" durante o período de recuperação.

O procedimento usado pela professora para ensinar números exigia que as crianças pudessem um traço após cada número, separando-os. A maioria das crianças não seguia a instrução. Ela repetiu a instrução três vezes com as crianças individualmente. Em um ponto, a professora olhou para o caderno de uma criança e disse:

Douglas - Tá certo ? (Ela olha de um lado e do outro do caderno). Professora - Tudo errado. Pode apagar e botar os tracinhos todinhos. Que você não colocou. Tá tudo errado. (Douglas volta para seu lugar). (Ela dá uma olhada superficial no garoto que está sentado ao lado de Ronaldo. Vai para o outro lado da sala ver o caderno de Dolores. Fica alguns segundos lá passando o dever para ela depois chama a atenção de Leandro que estava distraído). Alguns minutos mais tarde Douglas é abordado pela professora em sua carteira, ela fala: Professora - Olha aqui...(diz para Douglas) coloca o tracinho aqui pra dividir, ó....! Olha aqui! Não tô entendendo Douglas, coloca os tracinhos aí direito, Douglas, pelo amor de Deus! Faz isso aqui direito. Tá tudo embolado! (vai até Gilson, pega uma folha que ele estendeu, olha e dobra em duas). Professora - Não tô endendo nada! (Diz ainda 
se referindo ao dever de Douglas). Professora - Cola um número em cima do outro. Anda Douglas. Não tô entendo nada o que você está escrevendo! (Coloca a folha que estava em suas mãos na última carteira no lado direito).

Em outro segmento a professora ensinava sequência numérica, ela 'ajudava' uma criança, mas a reação da criança foi tentar esconder a cabeça com a camiseta. Este segmento ocorre assim:

Ronaldo - Tia, vem cá (A professora vai até ele). Professora - conta, 1, 2, 3... 4, 5, 6. . depois do 6 ? 7, 8, 9...10, 11, 12 e assim vai. Depois do 12, conta... depois do 12 vem que número? ...Depois do 12 vem que número, que número? ...13. Conta direito! 13. Conta! 14, 15. Coloca ele aqui... Não foi 15 aqui? Conta aqui. 16, 17, 18. (fala sem nehuma paciência e com rudeza na voz. Um garoto próximo de Ronaldo estende seu caderno para ela. Ela olhou sem atenção, colocou o caderno na carteira e começou novamente com Ronaldo). Professora - (....) conta... conta ...depois do 6 vem que número? 7, 8, 9. Depois conta, 10, 11,12. Depois vem? ...Depois do 12 qual que vem Ronaldo? ...É assim... (O garoto ao lado de Ronaldo estende o caderno a ela. Ela dá uma olhada, depois larga o caderno e vai corrigir de novo o caderno de Ronaldo). Professora - 15... depois do 15... Depois do 15 Ronaldo? (Ronaldo diz 13) 13 Ronaldo! Cê tá cansado de saber isso! (Diz com raiva batendo com a mão espalmada na carteira). 15, depois do 15? Que número que vem Ronaldo? Ronaldo depois do 15 que número que vem? Depois... 16, 17, 18!... Contando de 3 em 3 Ronaldo! Perde aula Ronaldo, perde! $18 .$. depois conta... 19, 20... Depois do 20?.. (Dá um soco na mesa com a mão fechada... Ronaldo tenta esconder-se com a camisa 
timidamente demonstrando medo). 1, 2, 3... $4,5,6 \ldots 7,8,9 . . .10,11,12 \ldots 13,14,15 \ldots 16,17$, 18...19, 20, 21. (Agora olha para o caderno do outro menino e começa a escrever. Moisés não está fazendo nada e ela bate com a ponta da caneta três vezes na cabeça dele). Professora - Dever... (Diz entre os dentes).

No exemplo acima, transcrevemos um segmento onde a professora demonstra, em sua fala, que alguma coisa 'tinha que estar errado' com o Ronaldo; lembrando ao menino que ele sabia contar, pois ela já havia ensinado. Ela insinua que ele não havia aprendido, deslocando a responsabilidade de si mesma e atribuindo-a ao aluno. Na visão da professora, o aluno não aprendeu a contar por que não quis. Inferimos que existe uma dicotomização entre ensinar e aprender. Ela separa ensino de aprendizagem para tornar o aluno responsável pelo seu próprio fracasso.

Uma característica da interação da professora com a sua turma é que a ela interagia com os alunos e alunos individualmente, dando a impressão de que ela interessava-se por cada um deles. Ela chamava cada um pelo nome, sabia onde cada um devia sentar e em que tarefa cada um deveria estar trabalhando. Sua familiaridade com os alunos era um meio de controle; para reforçar a disciplina e mantê-los trabalhando. Ela usava comentários ameaçadores durante todo o período registrado no vídeo e durante as suas aulas em outras observações realizadas em sua classe. A ameaça era uma das características que marcaram a interação da professora em sala de aula, e foi destacada para análise juntamente com outros tipos de interações negativas: agressão verbal (gritar com os alunos) e agressão física (bater nas cabeças, mãos e carteiras dos alunos), estes eram os meios pelos quais esta professora interagiu com a turma durante o período estudado por vídeo.

Contudo, os alunos continuavam a sair de suas carteiras e não trabalhavam a maior parte do tempo, conversavam. Alunos ficavam falando alto que não fariam o que ela lhes pedia. Outros alunos não diziam nada, mas não faziam nenhum trabalho também, numa atitude de restrição à produção. Uma primeira 
impressão sugeria que os alunos/as trabalhavam e que a professora usava a nota como instrumento de pressão para obter rendimento, mas uma análise do contexto torna evidente que nem ela esperava um grau de produção que lhes levassem a superar a reprovação latente nem os/as alunos/as pretendiam produzir. Esta situação evidenciava a supervalorização de aspectos como: disciplina, reforço negativo, ameaça, castigo, abuso físico, indisciplina e, até, a aceitação. Tal aceitação que parecia ser considerada "comportamento adequado" para alunos de zona rural, pode ser interpretada como uma forma de resistência passiva ao comportamento da professora em sala de aula.

\section{Violência na escola: 'tirando a cadeira'.}

A professora nesse vídeo solicita a um aluno que está em pé, quase a sua frente, que se assente em seu lugar e o faz entoando a sua voz muito além do habitual (CASTRO, 2006). Em um outro recorte dessa mesma filmagem, a professora retira a cadeira do aluno porque ele saiu do seu lugar.

Professora: Marcelo, vai sentar no seu lugar. Marcelo: Não quero sentar não. Professora: Você não quer ficar sentado não? Então vou tirar sua cadeira e vou te deixar em pé até o final! Tá bom assim? (Ela arrasta a cadeira para frente da sala. Ele fica passeando pela sala ) Professora: Mas também você vai ficar parado aí! (Ela retoma o texto e Marcelo deita no chão, colocando a mochila como assento) Professora: Marcelo, você parar de palhaçada ou vou ter que tirar você da sala de aula? (Agora, o aluno está de joelhos e apoiado na mesa) Pega sua cadeira! Vai lá! (O aluno não se levanta e a professora pega a cadeira)

\section{Violência na escola: as 'brigas'}

Foram presenciadas e gravadas em vídeos brigas violentas em sala de aula (MATTOS, 2008). Essas ocorriam por qualquer motivo e não havia distinção de sexo, todos brigavam entre si. 
Um dos alunos entrevistados declarou que o pai estava preso porque trabalhava no crime organizado. Portanto, o comentário dos alunos procede. Muitos outros entrevistados declaram conhecer pessoal ligadas as organizações criminosas da Favela da Rocinha e que isso lhes causava medo e insegurança. De acordo com as entrevistas, as brigas eram tidas como a maneira de resolverem suas 'questões'. Uma das razões apontadas por um dos alunos para explicar essa atitude foi que a maior parte dos alunos era 'filho de bandido', e entre eles era 'assim que se resolviam as coisas'.

Os resultados dessas brigas culminavam, umas vezes, com a presença dos responsáveis na escola para registrar queixa junto a professora. Outras vezes, a vítima, temendo sofrer nova violência faltava às aulas. Mas, via de regra, o que acontecia era a formação de grupos em que os mais fracos se submetiam à proteção de um mais forte com reconhecimento na turma. A exemplo, na turma da Progressão II havia um aluno denominado Capitão. Era um jovem de dezesseis anos que liderava os demais alunos. Os alunos só permaneciam em sala de aula sem sofrer qualquer tipo de violência com a sua permissão.

A Escola pesquisada funcionava, em 2006, em dois regimes simultâneos - o seriado e o de Ciclos de Formação (que inclui a Classe de Progressão), ou seja, após três anos o aluno, que era reprovado, continuaria na segunda série ou passaria a Progressão I ou II. Os alunos da Progressão II eram mais velhos (entre nove a dezessete anos), alguns 'dois ou três', tinham condições de passar para a terceira série. Outros eram igualmente fracos como os da Progressão I mas eram repetentes cinco ou mais vezes. Os alunos da Progressão I eram mais jovens (entre nove a treze anos), a maioria, muito fraca no desempenho escolar e repetente poucas vezes ( uma a três vezes).

O aluno chamado como Capitão tinha o reconhecimento também da professora e da direção da escola enquanto líder da sala. A observação dessa situação nas Classes de Progressão II nos sugere ser uma reprodução das gangues das favelas Cariocas e das formações do crime organizado no interior da sala de aula. 


\section{Considerações finais}

Este capítulo busca apresentar um recorte de pesquisas etnográficas sobre exclusão e fracasso escolar tendo como eixo a violência na escola. As imagens etnográficas da violência institucional 'espaço de segregação', 'ironia' e 'dever', e da violência na escola 'tirando a cadeira' e 'brigas' constituem exemplos de processos que negam os sujeitos de ensinar e de aprender.

Para continuarmos a reflexão recorremos a Paulo Freire (1996, p.36) que assinala a 'especificidade humana' do ensinar. Ele afirma que "no fundo, o essencial nas relações entre educador e educando, entre autoridade e liberdades, entre pais, mães, filhos e filhas é a reinvenção do ser humano no aprendizado de sua autonomia”(Ibid, p.37). Isso significa que para os sujeitos de ensinar são essenciais as dimensões de segurança, competência profissional e generosidade. Por isso, segundo Paulo Freire (1996, p.37)., "a disciplina verdadeira não existe na estagnação, no silêncio dos silenciados, mas no alvoroço dos inquietos, na dúvida que instiga, na esperança que desperta”. Ou seja, os educandos que exercitam a liberdade, ficarão tão mais livres quanto mais forem assumindo, eticamente, a responsabilidade de suas ações. A autonomia, que se funda na responsabilidade da liberdade que se assume, constrói-se penosamente preenchendo-se espaços vazios de autonomia, ou seja, os antes habitados por dependência e submissão.

A "reinvenção do ser humano no aprendizado de sua autonomia”, ou seja combater a violência por dentro de sua própria prática, é função da escola. Isso implica expandir direitos para a diversidade e a desigualdade de formas de viver a infância e a adolescência. O desafio nos chega nas palavras de Arroyo (2007, p. 805):

Desconfia-se da educabilidade dessas infâncias, a tal ponto de serem expulsas das escolas ou reclusas em agrupamentos especiais. Vem se afirmando uma cultura de que a escola pública deve estar aberta apenas para os 
humanizáveis. Quando as possibilidades de humanização e de educabilidade são vistas como uma exceção, inclusive desde a infância, a Pedagogia se autodestrói. Será possível reverter essa visão tão pessimista e essa redução do fazer educativo como uma tarefa de exceção? Para poucos?

Nessa direção, nossa reflexão continua interrogando as políticas educativas, de currículo e de formação de educadores. Como as violências e as reações à violência infanto-juvenil têm impactos na função da escola e da docência, na imagem dos educandos e especificamente na imagem da infância e adolescência populares? Se a caracterização de alunos como 'menores, delinquentes, infratores' aponta para uma descrença em sua educabilidade, como repensar a teoria e prática educativa? Como repensar as concepções de educação, de formação e desenvolvimento humano e as funções da escola e da docência? Na tensão entre educabilidade e desumanização, como repensar a escola como espaço público e de direito de todo cidadão à educação, particularmente de infâncias-adolescências tão precarizadas? 


\section{Referências}

ABRAMOVAY, M.; AVANCINI, M. F. A violência e a escola: o caso Brasil. Brasília: UNESCO, 2003.

ABRAMOVAY, M.; RUA, M. das G. (coord.). Violências nas escolas. Brasília: UNESCO, 2002.

ABRAMOVAY, M. (coord.). Escolas de paz. Brasília: UNESCO e Governo do Estado do Rio de Janeiro / Secretaria de Estado de Educação, Universidade do Rio de Janeiro, 2001.

ARENDT, H. Between past and future. Nova York: Meridian Books, 1961.

Sobre a violência. Rio de Janeiro: Relume-Dumara, $1969 / 1994$.

ARROYO, M. G. Quando a violência infanto-juvenil indaga a pedagogia. Educação \& Sociedade, Campinas, vol. 28, n. 100 Especial, p. 787-807, out. 2007.

BOURDIEU, P. 0 poder simbólico. Rio de Janeiro: Bertrand Brasil, 1998.

BOURDIEU, P.; PASSERON, J-C. A reprodução: elementos para uma teoria do sistema de ensino. Rio de Janeiro: Francisco Alves, 1975.

CANDAU, V. M.; LUCINDA, M. da C.; NASCIMENTO, M. das G. Escola e violência. Rio de Janeiro: DP\&A, 1999.

CASTORIADIS, C. Encruzilhadas do Labirinto, 3. O Mundo fragmentado. Rio de Janeiro: Paz \& Terra, 1992.

CASTRO, P. A. Controlar para quê? Uma análise etnográfica do controle na interação entre professor e aluno na sala de aula. 2006.187 f. Dissertação (Mestrado em Educação) -Faculdade de Educação, Universidade do Estado do Rio de Janeiro, Rio de Janeiro, 2006. 
CHARLOT, B. A violência na escola: como os sociólogos franceses abordam essa questão. Sociologia, ano 4, n.8, p.432-443, jul/ dez.2002.

CHARLOT, B.; ÉMIN, J-C (coord.). Violences à l'école - état des savoirs. Paris: Masson \& Armand Colin Éditeurs, 1997.

CHESNAIS, J-C. Histoire de la violence. Paris: Éditions Robert Laffont, 1981.

COLOMBIER, C.; MANGEL, G.; PERDRIAUT, M. A violência na escola. São Paulo, SP: Summus, 1989.

CRISP - Centro de Estudos em Criminalidade e Segurança Pública. Violência nas escolas de Belo Horizonte e da Região Metropolitana. Belo Horizonte: UFMG/CRISP (apoio da FAPEMIG), 2002 Disponível em <http://www.crisp.ufmg.br/ escolas.htm>. e em <http://www.fundep.ufmg.br/homepage/ cases/514.asp>. Acesso em 16/6/2007.

DANDOUN, R. A violência. Ensaio acerca do "homo violens". Rio de Janeiro: DIFEL, 1998.

DEBARBIEUX, É. A violência na escola francesa: 30 anos de construção social do objeto (1967-1997). Educação e Pesquisa, São Paulo, v.27, n.1, p. 163-193, jan./jun. 2001

La violence en millieu scolaire. Paris: ESF, 1998.

DUBET, F. A propos de la violence et des jeunes. Cultures \& Conflits, n.6, p. 7-24, 1992.

FOUCAULT, M. L'éthique du souci de soi comme pratique de la liberté. Dits et Écrits, Vol. IV, Paris: Gallimard, 1994.

FREIRE COSTA, J. Violência e psicanálise. Rio de Janeiro: Graal, 1984.

FREIRE, P. Pedagogia da autonomia. Saberes necessários à prática educativa. São Paulo: Paz e Terra (Coleção Leitura), 1996 Biblioteca Digital Paulo Freire, UFPB, s.d 
FREIRE, P. Pedagogia da esperança. São Paulo: Paz \& Terra, 1987.

GUIMARÃES, E. Escolas, galeras e narcotraficantes. Rio de Janeiro: UFRJ, 1998.

MAFFESOLI, M. A conquista do presente. Rio de Janeiro: Rocco, 1984.

Dinâmica da violência. São Paulo: Revista dos

Tribunais/ Vértice, 1987

O tempo das tribos. Rio de Janeiro: Forense, 1994

MATTOS, C. L.G. Incluindo diferenças: uma proposta para professores comprometidos com alunos de risco sócio-educacional num município do Estado do Rio de Janeiro- a oficina sobre Violência na Escola . In: FONTOURA, H.A. (org) Diálogos em Formação de Professores: pesquisas e práticas. Niterói: Intertexto, 2007a.

MATTOS, C. L. G. e CASTRO, P. A. de. Análises etnográficas das imagens sobre a realidade do aluno no enfrentamento das dificuldades e desigualdades na sala de aula. In: BARBOSA, 0. I.; ALVES, N.; BARRETO, R, G. Pesquisa em Educação: métodos, temas e linguagens. Rio de Janeiro: DP\&A, 2005, p. 103-116.

MATTOS, C. L. G. A pesquisa etnográfica sobre o fracasso escolar no Brasil nas últimas duas décadas. Conferência Faculty of Education at Cambridge University, UK, 2007.

MATTOS, C. L. G. Fracasso Escolar: Imagens de Explicações Populares sobre "Dificuldades Educacionais" entre Jovens de Áreas Rural e Urbana do Estado do Rio de Janeiro. Revista Brasileira de Estudos Pedagógicos. Brasília, DF, v. 73, n. 174, p. 361-379, maio/ agosto,1992.

MATTOS, C. L. G. Fracasso escolar: imagens de explicações populares sobre "dificuldades educacionais" entre jovens de áreas rural e urbana do estado do Rio de Janeiro, Relatório final de pesquisa, UFF/INEP, MEC: Brasília, DF, 1996. 
MATTOS, C. L. G. Imagens Etnográficas da Inclusão Escolar: o fracasso escolar na perspectiva do aluno. Relatório Final de Pesquisa. FAPERJ/ PROCIENCIA/ UERJ: Rio de Janeiro, RJ, 2008.

MATTOS, C. L. G. O espaço da exclusão: O limite do corpo na sala de aula. Relatório Final de Pesquisa Fracasso Escolar. INEP, 1994a.

MATTOS, C. L G. Picturing school failure: a study of diversity in explanations of educational difficulties of difficulties among rural and urban youth in Brazil. 1992. 268f. Thesis. (Ph. D. in Education) - Graduate School of Education, The University of Pennsylvania, Philadelphia. USA, 1992.

MATTOS, C. L.G. A ironia na interação professor aluno: de Sócrates ao século XXI uma estratégia didática. In: Anais do III Encontro Internacional A educação e Mercosul: Desafio Político e Pedagógico, São Paulo, 1994b.

MATTOS, C.L.G de. Imagens da exclusão na microanálise da sala de aula: uma instância interativa de confronto social. Rio de Janeiro: UERJ/ProPEd, Relatório Final de pesquisa, UFF/INEP, 1994c.

MATTOS, C.L.G de. Imagens da exclusão na microanálise da sala de aula: uma instância interativa de confronto social. Rio de Janeiro: UERJ/ProPEd. Relatório de pesquisa, INEP, 1994.

MATTOS, Carmen L.G. A pesquisa etnográfica sobre o fracasso escolar no brasil nas últimas duas décadas. Texto apresentado em Conferência proferida na Faculdade de Educação da Universidade de Cambridge, UK, em 18 de abril de 2007, p.18.

MATURANA, H. Formação humana e capacitação. Petrópolis, RJ: Vozes, 2000.

PINO, A. Violência, educação e sociedade: um olhar sobre o brasil contemporâneo. Educação \& Sociedade, Campinas, vol. 28, n. 100 - Especial, p. 763-785, out. 2007 
SPOSITO, M. P. Um breve balanço da pesquisa sobre violência escolar no Brasil. Educação e Pesquisa. Revista da Faculdade de Educação da USP. São Paulo: USP, v 27, n. ${ }^{\circ}$ 1, p. 87-103, jan./jun. 2001.

SPOSITO, M. P. A instituição escolar e a violência. Cadernos de Pesquisa, São Paulo: Fundação Carlos Chagas, n. 104, p. 58-75, jul. 1998.

SPOSITO, M. P. A sociabilidade juvenil e a rua: novos conflitos e a ação coletiva na cidade. Tempo social. Revista de Sociologia da USP, v.5, n.1-2, São Paulo, 1994.

TAVARES DOS SANTOS, J. V. A violência na escola: conflitualidade social e ações civilizatórias. Educação e Pesquisa, São Paulo, v.27, n.1, p. 105-122, jan./jun. 2001.

UNESCO. Abrindo espaços: educação e cultura para a paz. Brasília: UNESCO, 2001.

WAISELFSZ, J. J. Mapa da violência 3 - Os jovens do Brasil. Brasília: UNESCO, Instituto Ayrton Senna e Ministério da Justiça, 2002.

. Mapa da violência: os jovens do Brasil. Brasil:

UNESCO, 1998.

WERTHEIN, J. Juventude, violência e cidadania. Brasília: UNESCO, 2000. 



\section{As interações de gênero e de poder em instituições de internação de jovens em cumprimento de medidas socioeducativas: um estudo etnográfico.}

Carmen Lúcia Guimarães de Mattos Sandra Maciel de Almeida

Neste capítulo são revisitados dados da pesquisa intitulada Metacognição em Sala de Aula: um estudo sobre os processos de construção do conhecimento na perspectiva do jovem infrator no Estado do Rio de Janeiro (MATTOS; ALMEIDA, 1999) e de três pesquisas recentes, a primeira Gênero e pobreza: a situação educacional dos filhos e filhas de mulheres presas e dos filhos e filhas de jovens infratoras no estado Rio de janeiro (MATTOS; ALMEIDA; CASTRO, 2011) ora finalizada. A segunda e terceira, em desenvolvimento pela equipe de pesquisa Etnografia e Exclusão (GRPesq/CNPq), no Núcleo de Etnografia em Educação (netEDU) da Universidade do Estado do Rio de Janeiro (UERJ), são respectivamente Mulheres encarceradas e seus filhos (as): vulnerabilidades, desigualdades e disparidades socioeducacionais e suas intersecções de gênero e pobreza um estudo etnográfico em Brasília e Rio de Janeiro (MATTOS; ALMEIDA; CASTRO, 20112013 e 2) A educação de mulheres em espaços de exclusão: uma abordagem etnográfica (MACIEL; MATTOS, 2009 - 2012).

A base de dados que compõe esse texto foi retirada da revisitação de dados da pesquisa Metacognição. Entretanto, o processo analítico inclui dados das outras três pesquisas na medida em que o retorno ao mesmo local da pesquisa Metacognição permitiu às autoras a comparação de dados encontrados uma década depois. 
O foco das análises, apresentadas neste capítulo, está nos processos de construção das interações de gênero e de poder. Analisa-se ainda, o papel da feminilidade e da masculinidade nessas interações. Este papel foi revelado pelas falas das jovens, do sexo feminino, internas do Sistema de Atendimento ao Jovens em Conflito com a Lei do Estado do Rio de Janeiro (que será denominado pela sigla SAJCL/RJ no sentido de preservar o nome das Instituições que participaram das pesquisas). Contribuíram para as análises, além das falas das internas, dados obtidos com a colaboração do staff das intuições, fotos, documentos, entrevista, registros de observações e entrevistas, dentre outros.

As teorias que contribuíram para a consolidação das análises foram subsidiadas pelos conceitos de vigilância e controle dos corpos (FOUCAULT, 1995; 1996), da dominação masculina e violência simbólica (BOURDIEU, 1999) e de masculinidade e feminilidade (CONNELL, 2002).

Como ponto de partida para entender o objetivo do texto destacou-se uma frase de uma das internas da escola feminina de Ensino Fundamental em uma das unidades de internação e escola do SAJCL/RJ. Ela diz "Não tenho mãe nem pai, sou entregue na mão da rua”. Esta frase, resume em parte, a desesperança e agonia expressa por essa jovem de 13 anos de idade e pode ser tomada como uma síntese das histórias de muitas outras jovens que encontram-se internas em instituições pelo Brasil. Elas relataram suas vidas de abandono e descaso, às vezes desde o berço. Elas clamaram por justiça e liberdade, que no Brasil, assim como em inúmeros países do mundo, se traduzem em celas disfarçadas de escolas e penas nomeadas de medidas socioeducacionais. Escolas e medidas que, muitas vezes, são vistas por essas menores como um passaporte para um futuro que antes da prisão não era parte de suas vidas. A esperança de uma vida melhor, mais justa, uma mudança de vida, proposta pela ressocialização as deslocam, mesmo que por algum tempo da uma zona de vulnerabilidade social em que se encontravam e as empurram para um espaço/tempo de esperança. Esperança essa que, de certa forma, está ligada a imposição da frequência a uma escola, as normas e limites 
agora vividos na instituição. Esperança de que esta escola e estas vivências forneçam um mínimo de conhecimentos e habilidades garantidos por lei e necessários à vida em liberdade das jovens internas em instituições de cumprimento de medidas socioeducacionais.

A relevância do estudo sobre interações de gênero e de poder no contexto das escolas oferecidas às jovens internas pelo sistema de internação reside no fato de que esta temática, embora esteja presente em estudos recentes, ainda não esta consolidada na área da Educação (ROSEMBERG, 2001; SPONCHIADO, 1997; ASSIS; CONSTANTINO, 2001).

O impacto dos relatos das jovens participantes da pesquisa causado nos pesquisadores que as ouviram, assim como a invisibilidade das mesmas expressas nas inter-relações institucionais nos espaços socioeducativos, precisam ser descritas e apresentadas, para que se possa repensar as especificidades da educação de mulheres, em geral e da educação de mulheres em espaços de privação de liberdade, em particular.

Assis e Constantino (2001) em pesquisa sobre a situação dessa jovens no Rio de Janeiro destacam que as unidades de internação, com raras exceções, continuam a reproduzir a repressão, os maus tratos, a burocracia, a normatização e imposição disciplinar como formas de gerenciamento da institucional.

Os dados que serão apresentados a seguir demonstram que embora as instituições tenham tentado mudar este tipo de postura gerencial e interacional, mantem e reproduzem práticas pouco humanizadas nas relações que estabelecem com as internas.

\section{O controle e a punição}

O controle dos corpos e a punição física são instrumentos comuns nas instituição prisionais. Estes instrumentos são utilizados pelos agentes educacionais que lidam com as internas, pelos professores, membros do staff institucional, do Estado como os professores e os dirigentes das escolas, os promotores, juízes, os agentes de saúde e assistência social que atendem as 
jovens desde o dia em que foram são apanhadas num ato infracional até o final do cumprimento das medidas socioeducativas. O controle dos corpos e a punição física tem como objetivo a manutenção da ordem e da submissão das jovens inseridas no sistema. Embora ainda presentes até hoje no SAJCL/RJ, essas práticas são menos comuns. A pesquisa de Mattos e Almeida (1999) sinalizou como se dava o controle e a punição, enquanto as novas pesquisas, anteriormente mencionadas, apontaram que estes recursos foram substituídos por outros como a prescrição de medicamentos do tipo tranquilizantes ou inibidores do comportamento agressivo, o isolamento físico, a supressão direitos e a violência simbólica, dentre outros.

As falas das jovens expressam a presença desses mecanismos de controle na época (1998).

Jovem: Aqui é briga todo o dia. Se você passasse um dia aqui, não ia querer voltar nunca mais.

Pesquisadora: A gente não vê isso aqui, né? Não vê ninguém brigando.

Jovem: É porque se brigar, depois apanha.

Pesquisadora: Apanha de quem?

Jovem: Do Rico. Um careca que tava lá fora.

(Entrevista com Maria, jovem interna, em 13 /11/1998).

Pesquisadora: O que aconteceu aqui essa semana?

Jovem: Abriram os armários lá da frente e roubaram cadernos, toalhas e foi tudo aparecer lá no quarto. Ontem ficamos trancadas nesse calor o dia todo, sem cigarro, sem TV e sem rádio. Treze pessoas num quarto nesse calor.

Pesquisadora: bateram em vocês?

Jovem: Não bateram não, só botaram quem fez de castigo, já ficamos trancadas no cubículo por causa da brincadeira de macumba.

(Entrevista com Mônica, jovem interna, em 27/11/1998). 
$\mathrm{O}$ ato restritivo do corpo e da conduta indicam que este corpo foi reduzido à parte do ambiente sendo transformado em objeto de poder e de manipulação tanto em sua forma quanto em seu lugar. Não possui um ser que o habita, é tão somente propriedade de quem detém o poder sobre ele. Assis e Constantino (2001) explicam que a contenção celular se torna a última alternativa, quando a contenção perimetral, as restrições, os gritos e os embates corporais entre adultos e adolescentes já não surtem mais os efeitos esperados (p.12). No ambiente de internação este meio de controle pela contenção dos corpos parece ser a única forma encontrada pelo sistema para conter as demonstrações de rebeldia, raiva, descontrole, resistência e descontentamento entre as jovens internas por estarem em um sistema sem a liberdade.

O tipo de punição, mais frequente na instituição para a limitação e contenção dos corpos, segundo o relato das jovens e dos funcionários da instituição, era o encaminhamento para um espaço denominado por eles como tranca. Na pesquisa de Mattos e Maciel (1999), os funcionários do SAJCL/RJ entrevistados pela equipe de pesquisa declararam ser necessário o uso desse espaço para manter o controle da disciplina. Dentre as entrevistas realizadas, citamos a fala de uma das professoras do Ensino Fundamental da Escola Estadual Maria da Penha sediada no interior da instituição feminina.

Não temos nada para esconder... Se tiverem que ir para o quarto individual vão. Se houver menina lá, vão ver [indicando que a equipe poderia verificar, pois sempre havia uma menina na tranca]. Naquele momento, aquela situação é necessária (Entrevista com Sheila do professora de Ensino Fundamental da instituição fermina do SAJCL/RJ em agosto de 1998).

Sheila explica que punição é uma medida exemplar para evitar o descumprimento à ordem e à disciplina necessária para $\mathrm{a}$ ressocialização das jovens. A professora convidou a equipe de pesquisa para conhecer a "tranca" chamada pelos agentes educacionais de "quarto individual". Verificou-se então, que como foi relatado pela jovem e pela professora, este era um espaço 
semelhante a uma cela de uma prisão, pequeno e escuro, com portas de ferro, isolado das demais jovens que ficavam em outra parte do prédio. Na pesquisa atual (MATTOS; CASTRO; ALMEIDA, 2010), observou-se que esta prática ainda está presente na instituição. Entretanto, o “quarto individual”, separado das demais jovens, foi extinto e as jovens punidas pela tranca, ficam trancadas em suas próprias “celas” individuais, sem gozar de nenhum privilégio, como ir para a escola, conversar com as outras jovens internas ou funcionários, ter horário de sol no pátio, dentre outros. Assistiu-se, em algumas das visitas à instituição em 2010, que as jovens quando estão no "quarto individual” ficam rebeldes e agitam as portas de ferro, tentando chamar a atenção dos agentes e de quem estiver passando perto das portas. A contenção do corpo nesse espaço utilizada como mecanismo de controle e coerção das jovens internas pode compreender um período de tempo considerado longo, tendo em vista que o tempo máximo de cumprimento de pena é de três anos, as internas declararam que ficam por, um, dois, até três meses, trancadas em isolamento. Dependendo dos acontecimentos na instituição e das formas de manifestação de rebeldia e resistência das jovens, um grupo, e não somente uma ou duas podem ficar contidas nas celas. Como afirmou uma das internas, em setembro de 2010, à equipe de pesquisa “ontem ficamos todas presas o dia todo!”.

A existência e a função desse quarto individual ou da tranca são conhecidos em diferentes instituições socioeducativas e de encarceramento do Brasil. Com diferentes nomes todas estão relacionadas com a ausência de formas mais humanizadas para promover a ressocialização dessas jovens em ambiente de internação, como relatam Assis e Constantino (2001).

Quartinho, quarto de reflexão, tranca, cubículo, solitária, cafua, cela, chiqueiro, baia são nomes que, em diversas partes do Brasil, os adolescentes colocam nesses lugares. Quanto mais intenso é o uso deste recurso, mas se evidencia a ausência de repertório pedagógico por parte dos agentes e a indigência relacional do ambiente, que impede a formação de vínculos verdadeiramente humanos entre educadores e educandas (p.12). 
Foucault (1996) analisa os espaços institucionais de exclusão associando as histórias desse locais sociais de aprisionamento e controle e estabelecendo a sua relação com o poder existente nesses locais. Segundo o autor,

seria preciso fazer uma 'história dos espaços'
- que seria ao mesmo tempo uma 'história dos
poderes' - que estudasse desde as grandes
estratégias geopolíticas até as pequenas táti-
cas do habitat, da arquitetura institucional,
da sala de aula ou da organização hospitalar,
passando pelas implantações econômico-
políticas (FOUCAULT, 1996, p.212).

Para o autor é possível estabelecer uma relação entre a história dos espaços e a história dos poderes das diversas formas de normatização institucional às dimensões políticas e econômicas da sociedade. Esta, ainda, associada à sujeição dos corpos, às punições e à própria arquitetura dos espaços que em sua geopolítica pode servir ao exercício desse poderes (FOUCAULT, 1996).

As análises resultantes das pesquisas desenvolvidas, pelas autoras desse texto, em dois períodos distintos (1999 e 2010) demonstraram que o controle dos corpos e o exercício do poder observados na instituição de internação das jovens era exercido tanto pela contenção de seus corpos em espaços de isolamento individual como a tranca, quanto pela tentativa de controle de suas mentes, em outros espaços como a sala de aula, o posto de atendimento à saúde, as oficinas pedagógicas e culturais, dentre outros observados nas instituições. O controle intelectual, afetivo e da criatividade faz parte do dia a dia dessas jovens. De um modo geral, as atividades socioeducativas oferecidas às jovens caracterizavam-se por conteúdos mínimos escolares, tarefas infantilizadas, oficinas sem conteúdo prático ou relacionado à vida social e produtiva. Na maioria das vezes, muito abaixo da capacidade educacional e intelectual dessas jovens. Exemplo desse tipo de situação pode ser observada na cena descrita abaixo.

Após observar a sala de aula da prof. ${ }^{\text {a Sheila }}$ junto com o coordenador pedagógico durante algum tempo, o coordenador explicou que ela 
[Sheila] trabalhava basicamente com a coordenação motora das meninas, que ainda não sabiam escrever. A atividade observada consistia em colar pedaços de papel azul sobre o nome ou a letra que a professora escreveu no quadro. Outro grupo de meninas realizava uma atividade onde pintavam um desenho do Mickey e da minnie - personagens de desenhos animados - em uma folha de papel previamente impressa pela professora (cena transcrita de observação de sala de aula uma das instituições de internação de jovens do SAJCL/RJ, observada no dia 23 de outubro de 1998).

Figura I - Ligando números de 1 a 3 e achando a sapatilha.

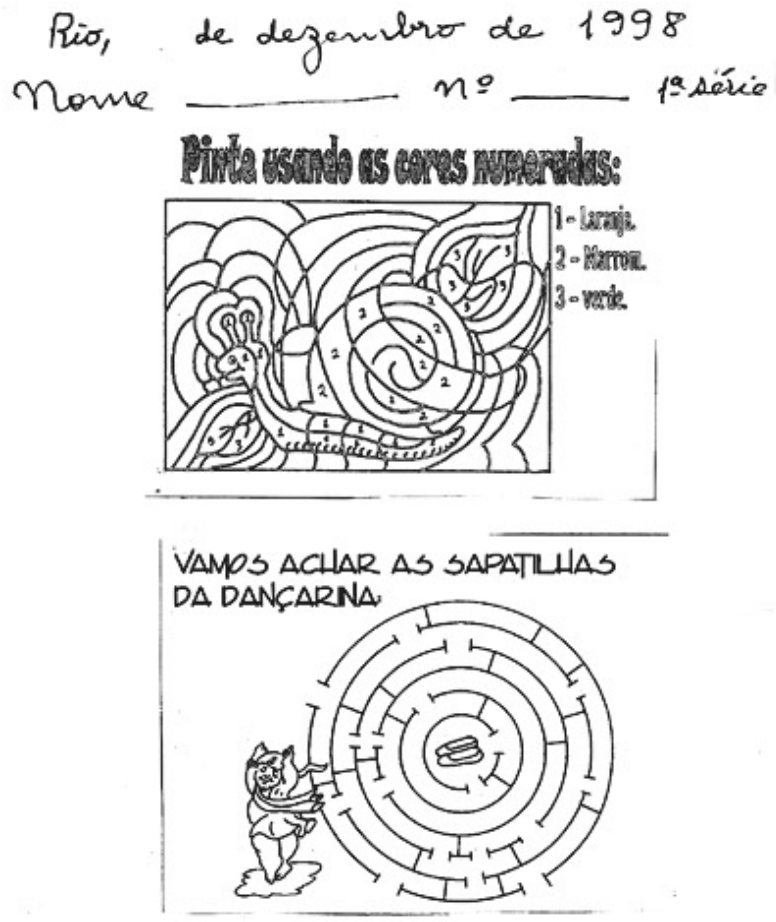

Fonte: Tarefa oferecida em uma das salas de aula do SAJCL/RJ e cedida pela professora de Ensino Fundamental à equipe de pesquisa. 
Tarefas dissociadas da realidade de jovens em conflito com a lei e sem propósito acadêmico ou educativo, como a situação acima, foram observadas em sala de aula e algumas dessas tarefas ilustram como eram há dez anos e como são hoje, alienantes e descontextualizadas as propostas socioeducativas da escola para essas jovens. Na ilustração da figura I a tarefa solicitada foi que pintassem em cores um desenho de um caracol e que ligassem uma bailarina à sapatilha, também utilizando cores. Esta tarefa carece adequação à realidade, clareza e objetividade acadêmica.

A diretora justificou o uso dessas tarefas afirmando que a instituição não tinha a pretensão de alfabetizar as jovens e sim de dar o mínimo para que "pelo menos elas saíssem sabendo escrever o nome".

O mesmo acontecia com as atividades como oficinas pedagógica, profissionalizantes e culturais. A atividade descrita abaixo ilustra uma das cenas observadas.

O funcionário do setor pedagógico durante reunião com a equipe de pesquisa descreve as atividades realizadas na instituição: - Mauro: Bordado, artesanato, artes cênicas, cabeleireiro [...] Temos também culinária. Ele foi interrompido por uma funcionária que disse - Eu sou Cristina. Não sou pedagoga, mas vou falar (olhando para Mauro). A instituição, quando funcionava aqui neste prédio, tinha um setor pedagógico organizado. Agora, não tem cursos profissionalizantes, só tem atividades para preencher o tempo (cena transcrita de uma reunião da equipe pedagógica, professores e funcionários de uma das instituições de internação de jovens do SAJCL/RJ, observada no dia 29 de setembro de 1998).

As atividades propostas nas salas de aula na instituição estavam relacionadas a conteúdos mínimos do início do ensino fundamental como: contar, somar, diminuir, copiar de escrever palavras ditadas ou atividades infantis, como pintar desenhos, colar arroz em volta do nome próprio, desenhar, recortar e colar desenhos e figuras de revistas, dentre outros. 
As atividades relacionadas à formação profissional na instituição de internação de meninas e jovens do sexo feminino eram tarefas consideradas socialmente como femininas, como: bordado, tranças e atividade de cabeleireiro, artesanato e culinária. $\mathrm{O}$ fato dessas atividades só estarem presentes na instituição feminina não era questionado pelas jovens, pelos professores ou funcionários, que quase sempre, descreviam essas atividades de forma naturalizada como parte da vida que elas deveriam ter ao saírem da instituição para serem donas de casa, domésticas ou mães de família. Recentemente (2010), observou-se que a instituição oferece as mesmas atividades de dez anos atrás, acrescidas de curso de informática que está associada a oportunidade de um trabalho de secretária ou de trabalho interno em escritórios.

Bourdieu (2002) explica que a dominação masculina contra as mulheres não repousa somente na violência física ou econômica, mas na violência simbólica e tem como resultado o fato de "as pessoas terem na cabeça princípios e percepções, maneiras de ver que são produto da relação de dominação" (2002, p. 49). Segundo o autor, "a violência simbólica não opera na ordem das intenções conscientes" (1999, p.74). Bourdieu (1999) sinaliza que a existência de uma dissimetria radical na avaliação das atividades masculinas e femininas, sendo que as tarefas delegadas aos homens são consideradas socialmente como sendo mais nobres e as femininas como inferiores.

As mulheres, de um modo geral na sociedade, assim como nessas instituições, são ensinadas a realizar determinadas funções e são, ao mesmo tempo, desencorajadas à realização de atividades que não sejam esperadas delas. Para Bourdieu (1999) esta forma de socialização seria como uma impotência aprendida. Ao oferecer atividades às jovens como o bordado, a culinária e o artesanato a instituição busca ratificar a condição feminina, reforçar a inferioridade dessas jovens através da infantilização de tarefas e formas de agir.

Assis e Constantino (2001) ratificam as palavras de Bourdieu dizendo que a "instituição oferece cursos voltados para o universo doméstico (corte e costura, bordado, culinária) ou de embelezamento pessoal. Não há preocupação com a escolarização formal” (p. 261). 
Foucault (1996) descrevendo os mecanismos de poder existentes nas prisões afirma que "a partir do momento que alguém entrava na prisão se acionava um mecanismo que o tornava infame, e quando saía, não podia fazer nada senão voltar a ser delinquente" (p.133). Uma das pesquisadoras, em entrevista, questiona uma das jovens sobre como era a vida na instituição, em resposta ela explica que "não tem amizade uma com as outras, são desunidas, fazem o que elas querem, não tem disciplina [...] Aqui tá todo mundo preso, só vive saindo briga”. O mecanismo de tornar sua condição infame opera em diferentes níveis no interior das instituições podendo ser observado tanto nas atividades programadas para as jovens quanto nas relações interpessoais.

$\mathrm{Na}$ fala da jovem a condição de interna em cumprimento de medida socioeducativa é percebida como uma prisão e não como um espaço de ressocialização. As jovens, ao realizarem tarefas pedagógicas, refletem em seus desenhos e falas a percepção de que foram retiradas de seus contextos de vida e inseridas em um sistema que representa um mundo à parte, surreal, sem sentido, ou mesmo caótico. Elas se percebem distantes do mundo em que viviam e do futuro que terão.

Ao retratarem sua autoimagem em um pôster afixado nas paredes da instituição essas percepções foram representadas por figuras distorcidas da realidade, o que revelou esta ausência de sentido. $O$ cartaz deteve a atenção da equipe de pesquisa, pois de acordo com as explicações do Orientador Pedagógico foi solicitado às jovens que em uma atividade de colagens de figuras, retiradas de revistas, comunicassem às visitas quem estava aniversariando naquele mês. De acordo com o Orientador o trabalho foi realizado com a orientação da professora de Artes. Ele comentou que a professora era uma pessoa muito comprometida com a solução dos problemas das meninas. Segundo ele o cartaz representava "o próprio estado mental delas - eram crianças grandes”. O cartaz - aniversariantes do mês - comum em ambientes interacionais de convivência social, como escolas e escritórios, foi montado na parede lateral da entrada interna da instituição que dava acesso ao pátio, onde todas as pessoas que entravam, necessariamente tinham que passar. 
Figura 2

Aniversariantes do Mês de Novembro de 1998
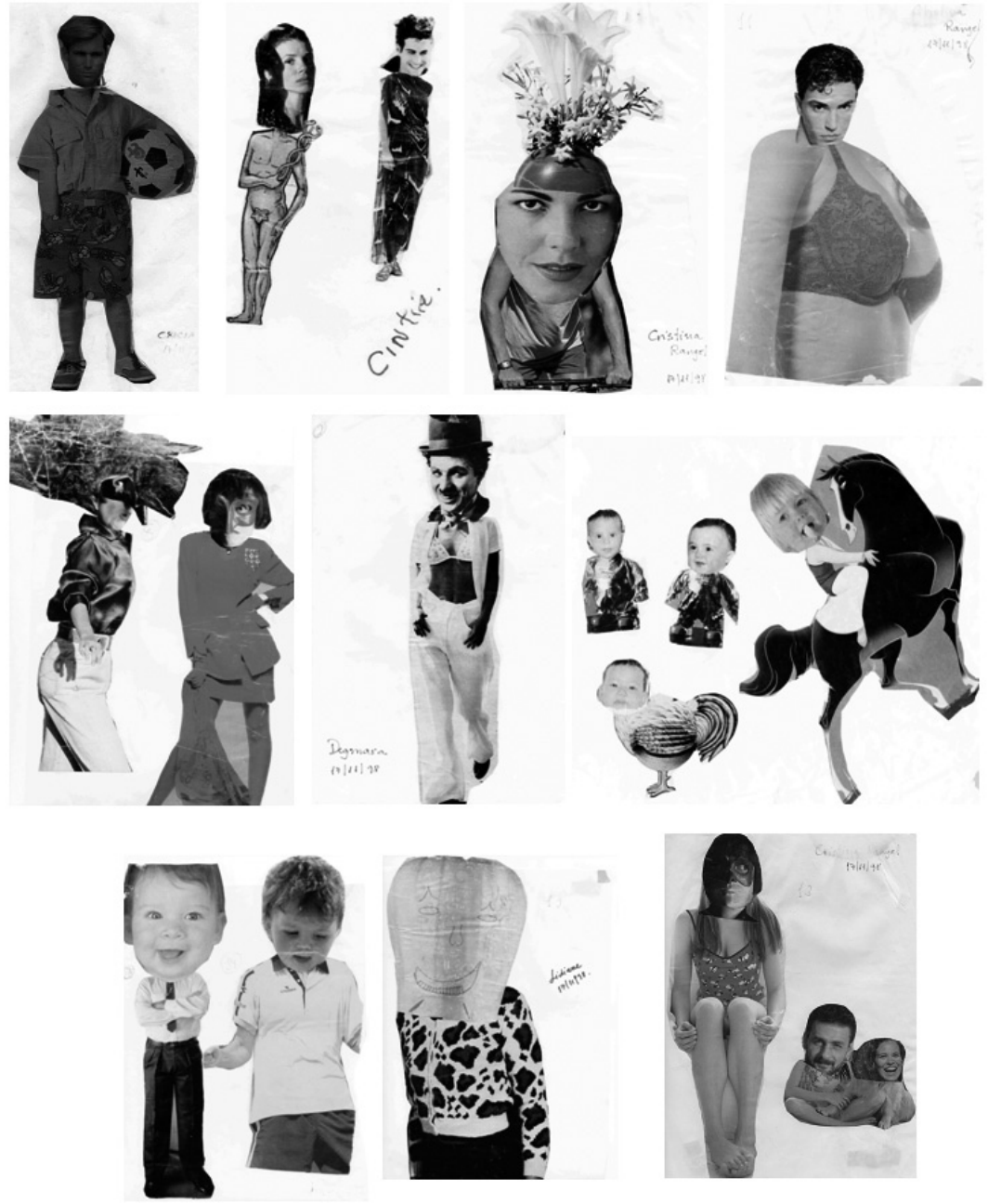

Fonte: Imagens de Mural da Instituição de Menores em Conflito com a Lei do Rio de Janeiro realizado em 19/11/98, e cedido pelo Orientador Pedagógico para a Equipe de pesquisa em 20/11/1998.

As imagens, assim como as interpretações dadas pelos participantes, evidenciam uma fantasia, uma desconexão com a realidade, uma construção surrealista e de difícil interpretação pela equipe de pesquisa. Entretanto, a construção visual sugere transgressões à ordem e à vida. Além disso, expressam 
identidades marginalizadas que foram reproduzidas no Mural através das trocas de papéis sexuais das figuras. Esta troca de papéis, pouco inteligíveis à elas próprias, foram percebidas pela instituição como uma confirmação da infantilidade das jovens que tinham suas mentes ocupadas com brincadeiras e irreverências.

O primeiro impacto verificado durante as análises realizadas pela equipe de pesquisa sobre este quadro e outras tarefas similares, foi de que havia uma forma de interpretação estética dessas jovens diferente das formas de representação da realidade fora do sistema. Isto sugere identidades em contradição com a vida contraventora do mundo do adulto que estas jovens experimentaram antes de entrar no sistema de internação. Mattos e Almeida (1999) ao analisarem as imagens acima, afirmam que:

....as colagens refletem a contradição do sistema institucional de menores revelando seu caráter antipedagógico e alienado e a ausência de um perfil identitário que aja de forma efetivamente socioeducativa sobre os valores sociais necessários para ressocialização da jovem infratora (p.11).

As condições institucionais oferecidas as jovens internas, ultrapassam os limites da privação de liberdade alienando-as e distanciando-as de um processo saudável, tanto físico quanto mental e afetivo, para a construção de perspectivas de superação da condição de contravenção. Assis e Constantino (2001) explicam que:

o sistema deveria privar as internas apenas da liberdade, isto é, do direito de ir e vir. A realidade, porém, é que elas são privadas também de respeito, dignidade, identidade, privacidade e da integridade física, psicológica e moral. Degradar para controlar, e 'controlar para degradar. Esta é a lógica que rege a engrenagem institucional (p.11). 
Utilizando as palavras das autoras, o movimento diário da engrenagem institucional favorece o controle dos corpos, o exercício da desconsideração pela integridade mental, afetiva e moral das jovens internas. A ausência de modelos pela falta de clareza das regras e critérios para a educação e ressocialização contribuem para a distorção das identidades dessas jovens, que já chegaram no sistema fragilizadas pela zona de vulnerabilidade social (CASTEL, 1997) em que viviam. Um dos aspectos mais degradantes das formas de desrespeito a si mesmas e as outras internas é a busca por relações sexuais e afetivas que, muitas vezes, não estão associadas as escolhas das próprias jovens, mas sim à situação de internação, conforme relatado por elas. Os corpos masculinizados e os relacionamentos homossexuais entre a maioria das internas são declarados como sendo uma forma de sobrevivência e proteção é interpretado pelo sistema como mais uma das deformações de caráter moral entre as jovens. Aspectos dessas formas de inter-relações pessoais serão tratados a seguir.

\section{Gênero e masculinidade nas interações das jovens internas}

A condição feminina, historicamente, tem sido associada às desigualdades sociais, mas é nas relações de poder que estas desigualdades são mais marcantes. Para enfrentar essas diferenças o governo brasileiro decidiu planejar e implementar estratégias políticas que assegurem os direitos às mulheres e, assim diminua essas desigualdades. Entretanto, nos últimos anos, os indicadores de desigualdades de gênero apresentados no relatório anual “Global Gender Gap Index 2010" durante o Fórum Econômico Mundial (FORUM MUNDIAL, 2010) demonstrou que embora esses esforços políticos sejam realizados no País, o Brasil continua descendo a patamares cada vez menores entre os países analisados e comparados pelo documento. O Brasil passou a figurar entre os países com um dos maiores índices de desigualdade neste quesito, entre os 134 países, descreu da $67^{\circ}$ posição em 2006 para a $85^{a}$ posição em 2010. 
Na escalada da diminuição das desigualdades continua-se a luta no sentido de conquistar melhores posições para o Brasil nos próximos anos. Dentre as estratégias políticas implementadas para diminuir as desigualdades, encontram-se as ações previstas pelo Plano Nacional de Políticas para as Mulheres (I PNPM, 2004; II PNPM 2008). II PNPM, em seu Capítulo 4 sobre "Enfrentamento de todas as formas de violência contra as mulheres” chama a atenção para o fato de que a violência contra mulheres constitui-se em uma das principais formas de violação dos seus direitos humanos, atingindo-as em seus direitos à vida, à saúde e à integridade física (SPM, BRASIL, 2008, p. 95).

Entretanto, para realizar as análises apresentadas neste texto, foram consideradas as dicotomias presentes nas políticas de gênero como: feminino/masculino, homem/mulher, dentre outros, que misturam concepções distintas de gênero, sexualidade e sexo biológico. Foi ainda necessário compreender os conceitos de gênero de modo a sinalizar quais as concepções que se aproximaram daquelas que orientaram essas análises, tomando como fonte principal os conceitos originários dos estudos de Raewyn Connell realizados por Mattos (2009).

Em recente relatório de pesquisa (MATTOS; CASTRO; ALMEIDA, 2011) os estudos sobre gênero foram sintetizados da seguinte forma:

Connell em seus estudos conceitua gênero de modo a auxiliar pesquisadores que buscam um significação mais ampla para o termo no que se refere ao seu uso para interpretar as diferentes formas de construção das masculinidades e feminilidades. Estas, são vistas como sendo, simultaneamente, posições nas relações de gênero, nas práticas pelas quais homens e mulheres assumem essa posição, assim como os efeitos dessas práticas no corpo, personalidade e cultura (CONNELL, 1995, p. 71). Gênero, nesse sentido, é compreendido como "a estrutura das relações sociais que centra-se na arena reprodutiva, bem como no conjunto de práticas (regidas por 
esta estrutura) que fazem distinções reprodutivas entre os corpos nos processos sociais" (CONNELL, 2002, p. 10). De acordo com teoria de Connell a ordem de gênero são arranjos convencionais de variações dos padrões e diversidades de composições de gênero nas sociedades contemporâneas, em especial nas metrópoles, que levam a interpretação de gênero, como "uma forma de ordenação política e social guiadas por estruturas de relações sociais de gênero" (CONNELL, 2002, p.3). Para a autora essas estruturas geralmente, parecem 'imutáveis', mas, elas são sempre mutáveis e que quando práticas humanas criam novas situações estas estruturas desenvolvem tendências a crises. Connell destaca as seguintes estruturas de gênero: 1) Relações de poder que podem ser evidenciadas nas instituições e no discurso de afirmação dessas relações de poder do homem sobre a mulher; 2) Relações produtivas, que se evidenciam através de valores, hábitos e da divisão de trabalho; 3) Relações emocionais e simbólicas que se evidenciam pelo apego, emoção, vida conjugal e no conjunto de regras de atribuição de gênero. Embora fora deste quadro estrutural, Connell não esquece a dimensão histórica e inclui em suas teorias a dimensão de gênero como história (p.14).

Como descrito acima, as interações sociais seguem uma ordenação de gênero produzida pelo indivíduo em sociedade. Esta ordenação inclui resistências e preconceitos de gênero nas diversas instâncias desta sociedade. Dentre as mais diversas formas de construção das identidades de gênero está a distinção e pertencimentos à papéis masculinos e femininos.

Connell (1997) define masculinidades como configurações de práticas sociais que se referem a corpos masculinos, estando elas tanto relacionadas à ordem simbólica e institucional como aos aspectos individuais dos sujeitos inseridos na sociedade. Connell (1995) trabalha, ainda, com a noção de "múltiplas masculinidades”, explica que estas são hierarquizadas a partir de 
relações de poder e que no centro delas existe uma "masculinidade hegemônica", que se manifesta como um conjunto de práticas e valores que tem a função de garantir a posição dominante dos homens e a subordinação das mulheres.

No caso específico da educação, Carvalho (2004) afirma que se deve fazer uma "discussão mais aprofundada sobre as masculinidades e as relações de gênero, de forma que se permita uma apropriação mais ampla das teorias da masculinidade" (CARVALHO, 2004, p. 36). Carvalho (2004) complementa a explicação sobre as masculinidades citando trabalhos de autores como Connell (1998, 2000), Mac; Ghaill (1995), Skelton (2001) e Kimmell (2000) e afirma que

homens e mulheres são produtos de relações sociais, históricas e culturais, num contexto em que se aprende não um único "papel sexual", mas convivem múltiplas masculinidades e feminilidades articuladas por relações de poder e perpassadas por outras relações sociais como as desigualdades de classe e raça (CARVALHO, 2004, p. 36).

As relações de poder existentes nos espaços de internação e que emergem dos conflitos de gênero evidenciadas por disputas relacionadas a vivencias entre as jovens são, geralmente, invisíveis ou naturalizadas pelo sistema indicando a força social das ordenações de gênero (CARVALHO, 2003; Saffioti, 2004). O gerenciamento do conflito é sempre uma preocupação dos professores e funcionários da instituição de internação feminina e as suas formas de resolução perpassam a permissão de atos e ações que envolvem as inter-relações corporais, sexuais e emocionais, como as descritas nas cenas a seguir:

Cena 1

Durante uma reunião com a equipe de pesquisa o funcionário Mauro do setor pedagógico, descreveu como se davam as relações entre as jovens na instituição. Ele explica que existe uma forma peculiar com que as meninas se tocam, elas enroscam umas às outras pelo chão de cimento da quadra de esportes 
coberta. Neste momentos a equipe podia ver na quadra de esporte, pela porta aberta da sala, a cena a que o professor se referia, as jovens reunidas em grupos de três ou quatro, estavam deitadas umas sobre as outras formando uma escultura disforme, um conjunto de membros que lembrava uma rosca humana, conversavam e cantavam alegremente. Mauro sorriu e disse: Esta é a forma de evidenciar a paz desta instituição e transmitir segurança, que é a nossa meta.

Durante uma reunião com os funcionários da instituição, o professor José afirmou que: - muita gente jogou o chapéu quando foi trabalhar na instituição, porque às vezes, a barra é muito pesada. A instituição feminina é diferente. Por ser mulher é mais aconchegante [...]. Neste momento a professora Maria responde: - Acho que ele quer dizer que a escola é mais transparente, em outras escolas demoram para deixar entrar. (...) as meninas são insinuantes. No instituto masculino os meninos andam de mãos para trás, cabeça baixa e só falam se você perguntar a ele. Na feminina elas se penduram no pescoço até da visita.

Durante uma reunião entre a equipe de pesquisa e a diretora da escola prof. ${ }^{\text {a }}$ Rita, ela comentou: "as meninas são mais espertas que os meninos e podem querer mandar bilhetes para fora. Já houve caso de as meninas enviarem bilhetes pelos PMs que ficavam na escola [...] Elas gostam muito de espelho [...] $O$ instituto feminino é menor, mas não é mais fácil que a dos meninos. A menina é mais sedutora, suga mais e se torna mais indisciplinada em sala.

(Cenas e transcrição de conversas entre a equipe depesquisa, professores. Funcionários e gestores da instituição de internação feminina do SAJCL/RJ nos dia 20 de novembro, 29 de setembro e 09 de outubro de 1998. 
Como demonstrado acima as jovens são consideradas insinuantes, aconchegantes, espertas e sedutoras e a instituição dos jovens do sexo masculino menos harmônica e mais difícil de lidar.

Segundo Bourdieu (2002), as estruturas sociais levam as mulheres a incorporar e interiorizar uma relação masculinofeminino de dominação. Em outro estudo o autor menciona que,

as mulheres não podem senão tornar-se o que elas são segundo a razão mítica, confirmando assim, e antes de mais nada a seus próprios olhos, que elas são naturalmente destinadas ao baixo, ao torto, ao pequeno, ao mesquinho, ao fútil, etc” (BOURDIEU, 1999, p. 41).

Nesta perspectiva, a visão dos participantes tanto as jovens quanto os outros citados acima, está em consonância com a fala de Bourdieu sobre a dominação masculina, não apenas pelas ações, mas principalmente pelo discurso e através deles a transmissão de valores sobre o que é ser feminino e seu significado social.

Segundo Assis e Constantino (2001) as jovens "infratoras comumente obedecem às ordens masculinas, mostrando a transposição da subalternidade para o meio infracional” (p.261). A relação entre o masculino e feminino na instituição se evidenciava não só na relação das jovens com os educadores e agentes de segurança, mas também entre elas.

Uma das características marcantes entre as jovens era a masculinização na aparência, no comportamento, nas formas de relacionamento entre elas, dentre outros. Elas se vestiam com roupas masculinas (ou por exemplo, transformavam 0 uniforme de modo a parecer masculino, como jogadores de futebol), faziam uso de gestos que copiavam os homens, cortavam os cabelos bem curtos ou raspavam as cabeças, apontavam suas namoradas em vários ambientes como a sala de aula ou durante entrevista, ficavam de mãos dadas e se abraçavam em lugares como a sala de aula e o pátio e se diziam seus homens. mantendo, uma atitude de superioridade e inferioridade a partir desta identificação de papeis. 
Essa observada no universo da institucionalização feminina, foi encontrada também na pesquisa de assis e constantino (2001), em que afirmam que as jovens "buscam agir como homens para poderem sobreviver no meio infracional, provando a todo instante que podem ser tão boas e fortes quanto eles [os homens]" (p.261). Em alguns momentos, no entanto, percebe-se que algumas jovens ao agirem como homens perpetuavam a violência da qual também eram vítimas contra suas próprias colegas que não queriam desempenhar papeis masculinos no ambiente de internação, numa atitude de dominação masculina explicada por Bourdieu (1999) e Connell (1995) .

\section{A homossexualidade institucionalizada}

As observações de campo e as análises descritas neste texto demonstram que a sexualidade como uma forma de manifestação da identidade se encontrava presente na instituição de internação feminina. Na medida em que se masculinizavam, as jovens se colocavam em uma posição de defesa frente às ameaças que sofriam na instituição que buscava a todo o tempo controlar e punir as digressões de comportamentos que não se submetiam as ordens institucionais.

Como afirmam Assis e Constantino (2001):

O homossexualismo de internato é uma cons-
trução institucional. Trata-se de algo quase
co-constitutivo da natureza destes espaços
de reclusão. O relacionamento entre pessoas
do mesmo sexo torna-se uma moeda de troca
da mais valia afetiva, que cada menina acu-
mula consigo. Existem as que resistem ao
jogo. Para muitas, porém, é a única maneira
de continuar interagindo no plano da afetivi-
dade (ASSIS; CONSTANTINO, 2001, p.11).

As falas abaixo demonstram como a instituição, através de seus funcionários, justifica e institucionaliza o homossexualismo das jovens, banalizando essas situações e, dessa forma, 
promovendo a construção de identidades masculinas entre as jovens do sexo feminino,

As jovens estão realizando uma atividade em sala de aula, neste dia, elas estavam especialmente agitadas e agredindo umas as outras e a professora. Algumas jovens realizavam a atividade que consistia em pintar desenhos do Mickey e da Minnie. Um das jovens abandona a tarefa sai da sala dizendo - Não quero fazer mais nada! Tô com dor no pescoço. Mauro, o coordenador pedagógico chega perto de uma das pesquisadoras e diz em voz baixa - as meninas estão muito agitadas, estão brigando entre si. Tudo isso devido a algumas meninas que chegaram nesta madrugada com o homossexualismo muito arraigado.

Durante entrevista dada por uma jovem à equipe de pesquisa ela fala sobre a homossexualidade na instituição e diz, - Eu sou menina mermo, tia. Tem menina que é sapatona lá fora mermo, mas tem uma que dá uma de sapatão e não são. Elas mandam carta para quem elas estão interessadas, se a pessoa responder já é porque quer ficar com elas. Elas chama pra sair, mas eu não quero não. Elas pediram para ficar juntas[...] Eu não sei, eu não sou sapatona, eu tenho namorado.

Durante uma atividade em sala de aula a professora propôs a produção de uma texto. Renata, uma das jovens, pediu para escrever uma carta. Ela tinha na mão uma folha de caderno ornada com corações vermelhos. A professora pergunta a Renata: - Você quer escrever para quem? Renata responde: - Para uma menina! Uma outra aluna rí e faz uma insinuação: - Aí, heim!!! Renata fala: - não é nada o que você está pensando... Eu sou au, au dela. Ela diz que eu sou au, au, dela! A 
Professora chama a atenção das duas dizendo: - nós já conversamos sobre isso de $\mathrm{au}, \mathrm{au}$, de dormir junto, de dar beijo na boca. Não é assunto de agora! A aluna para a quem Renata estava escrevendo a carta responde: estão pensando mal da gente!!

(Cenas e transcrição de conversa entre a equipe de pesquisa, jovens em conflito com a lei, professores e funcionários da instituição de internação feminina do SAJCL/RJ em 23 de outubro e 27 de novembro de 1999)

As situações descritas nas cenas acima reforçam a tese de que a homossexualidade na instituição de internação feminina é parte de uma construção institucional. Um dos dados apontados pelas pesquisas de Assis e Constantino (2001) e de Mattos e Almeida (1999) é que quase todas as jovens participantes dessas pesquisa foram vítimas de violência física, cerca da metade delas, de violência sexual e todas elas são vítimas de violência psicológica e abandono. Algumas jovens relataram terem sofrido violência sexual ainda enquanto meninas, na família, na rua e geralmente por alguém conhecido delas. E, quando internas, pelas próprias colegas na instituição e por pessoas responsáveis por elas no local. No relato abaixo uma das jovens comenta,

Jovem: Alí, no quarto do meio? [o quarto do meio foi identificado como o que é usado pelas jovens que se declaram homossexuais] é uma putaria, tia! Só dá sapatão! Eu dormindo no três, as meninas ficam se esfregando, pegando no meu peito durante a noite! [...] Eu estava na minha cama, no três e ficam falando: libera pra mim, libera pra mim! A pesquisadora questiona sem entender: - 0 que é liberar? Jovem responde: - é o negócio de dedada! [..] Da até briga ! Uma toma a mulher da outra, mas esse negócio não é comigo. A pesquisadora pergunta: - o coordenador toma providências? A jovem reponde: - eles aqui, tudo é safado! Tudo entrega carta de amor, só a Marília que não [ referindo-se 
a uma das agentes educacionais]. Entrega carta para sapatão! [elas] ficam à noite, não olham quem passa a mão, não olham quem passa de cama, ficam se esfregando.

(Transcrição de conversa da equipe de pesquisa com uma das jovens da instituição de internação feminina do SAJCL/RJ, s/d)

Ao assumirem um comportamento masculino as jovens assumem também uma atitude perversa contra as colegas, a dominação e violência, perpetuam a violência institucional. Numa demonstração de força a transformação da identidade, muitas vezes, sem intenção real de tornarem homossexuais, serve tanto para impor a autoridade junto às colegas, quanto para estabelecer uma simetria de forças com os profissionais da instituição, transforma-se em uma mensagem para os gestores e agentes educacionais. Nas fala da diretora da instituição as manifestações e interações homossexuais e a violência que ela trás no ambiente de internação constitui-se em um dos maiores problemas da gestão dessas instituições.

\section{Considerações finais}

Neste capítulo foram analisados de forma crítica dados de pesquisas sobre as interações de gênero e de poder e sobre os processos de construção da identidade e os papeis da feminilidade e da masculinidade entre jovens do sexo feminino, internas do Sistema de Atendimento ao Jovens em Conflito com a Lei do Estado do Rio de Janeiro. O texto é ilustrado a partir de vinhetas derivadas das falas de: jovens, professores, gestores, coordenadores pedagógicos e funcionários da instituição que participaram das pesquisas .

As análises focam o modo como as instituições socioeducativas lidam com as interações de gênero e de poder, ora naturalizando essas relações, ora as institucionalizando. A instituições passam uma dupla mensagem de que para controlar é preciso permitir. 
A condição de privação de liberdade de jovens, assim como as formas de ressocialização por elas vividas demanda análises constantes por pesquisas que possam promover questionamentos sobre como efetivamente a ressocialização pode se tornar uma possibilidade de futuro para essas jovens. Um dos questionamentos possíveis a estas pesquisas é quanto aos processos educacionais que em se pensando inclusivos poderiam favorecer aos jovens em um movimento crítico reflexivo sobre as suas realidades. Nesta perspectiva acredita-se que os dados deste capítulo podem contribuir para informar sobre a promoção de políticas públicas voltadas para compreender a dinâmica interna das instituições de internação, assim como as necessidades das jovens em situação de privação de liberdade no Brasil. 


\section{Referências}

ALMEIDA, S. M. Inclusão e exclusão: ouvindo os sujeitos privados de liberdade. Anais do II Colóquio Educação, Cidadania e Exclusão - Etnografia em Educação. Universidade do Estado do Rio de Janeiro, 2007.

ALTOÉ, S. Infâncias perdidas: o cotidiano nas internações-prisões. Rio de Janeiro: Xenon, 1990.

ASSIS, S. G. de; CONSTANTINO, P. Filhas do mundo: infração juvenil no Rio de Janeiro. Rio de Janeiro: Fiocruz, 2001.

BOURDIEU, P. A dominação masculina. Rio de Janeiro: Bertrand Brasil, 1999.

BRASIL. FORUM MUNDIAL. Indicador Global das Disparidades de Gênero. 2010.

BRASIL. Plano nacional de políticas para as mulheres.

Brasília: Secretaria Especial de Políticas para as Mulheres, 2008.

CARVALHO, M. P. de. Quem são os meninos que fracassam na escola? Cadernos de Pesquisa, v. 34, n. 121, jan./abr., 2004.

CARVALHO, M. P. de. Sucesso e fracasso escolar: uma questão de gênero. Educação e Pesquisa, São Paulo, v.29, n.1, p. 185-193, jan./ jun., 2003.

CASTEL, R. As armadilhas da exclusão. In: CASTEL, R.; BELFIORE, M.; WANDERLEY, L. E.W. Desigualdade e a questão social. $2^{\text {a }}$ Ed. São Paulo: EDUC, 1997.

CONNELL, R. W. La organización social de la masculinidad. In: VALDÉS, T.; OLAVARRÍA, J. (ed.). Masculinidades. Santiago, Chile: FLACSO/ ISIS Internacional, Ediciones de lãs Mujeres, 1997. p. 31-48.

CONNELL, R. W. Masculinities. Berkeley: University of California, 1995. 
COSTA, C. R.; ASSIS, S.G. Fatores protetivos a adolescentes em conflito com a lei no contexto socioeducativo. Psicologia e Sociedade, v. 18, n. 3, p.74-81, set.-dez., 2006.

DELL `AGLIO, D.; DOS SANTOS, S.; BORGES, J. Infração juvenil feminina: uma trajetória de abandonos. Interação em Psicologia, v.8, n.2, p.191-198, 2004.

FOUCAULT, M. Microfísica do poder. Rio de Janeiro: Graal, 1996.

FOUCAULT, M. Vigiar e punir: história da violência nas prisões. Petrópolis: Vozes, 1995.

FRANCISCHINI, R.; CAMPOS, H. R. Adolescentes em conflito com a lei e medidas socioeducativas: limites e (im) possibilidades. Psico, PUCRS, Porto Alegre, v.36, n.3, p. 267-273, set-dez, 2005.

FREIRE, P. Educação e mudança. Ed. Rio de Janeiro: Paz e Terra, 1983.

LOYOLA, M. A. Entrevista com Pierre Bourdieu. Pensamento Contemporâneo. Rio de Janeiro: EdUERJ, 2002.

MACIEL, S. de A.; MATTOS, C. L. G. de. Metacognição como proposta pedagógica. Projeto piloto da pesquisa "Metacognição em Sala de Aula”. Programa de Pós-Graduação e Educação da UERJ, 1999.

MATTOS, C. L. G de.; MACIEL, S. de A. A Metacognição no cotidiano dos jovens infratores: aprendendo a aprender em privação de liberdade. Relatório Final de Pesquisa. Volume 1. Rio de Janeiro: UERJ/SR3/DEGASE,1999.

MATTOS, C. L. G. de; ALMEIDA, S. M; CASTRO, P. A. de. Gênero e pobreza: a situação educacional dos filhos e filhas de mulheres presas e dos filhos e filhas de jovens infratoras no estado do Rio de Janeiro. Relatório de Pesquisa. CNPq, 2011.

OLIVEIRA, M. As Implicações psíquicas presentes no ato infracional de repetição. Educandário Santos Dumont. Relatório parcial de pesquisa. Rio de Janeiro: (Cópia Reprográfica), 1995. 
OLIVEIRA, M. Justiça é verdade em ação? 1999. Tese (Doutorado em Psicologia) - Departamento de Psicologia, Pontifícia Universidade Católica do Rio de Janeiro, Rio de Janeiro, 1999.

OLIVEIRA, M.; ASSIS, S. Os adolescentes infratores do Rio de Janeiro e as instituições que os "ressocializam": a perpetuação do descaso. Caderno de Saúde Pública, Rio de Janeiro, v.15, n. 4, p. 831-844, out.-dez., 1999.

ROSEMBERG, F. Caminhos cruzados: educação e gênero na produção acadêmica. Educação e Pesquisa, São Paulo, v. 27, n.1, p.47-68, jan./ jun. 2001.

ROSEMBERG, F.; PIZA, E. P.; MONTENEGRO, T. Mulher e educação formal no Brasil: estado da arte e bibliografia. Brasília: INEP/ REDUC, 1990.

SAFFIOTI, H. Gênero, patriarcado, violência. São Paulo: Fundação Perseu Abramo, 2004 (Coleção Brasil Urgente).

SPONCHIADO, J. I. Docência e relações de gênero: estudo da produção acadêmica no período de 1981 a 1995.1997. Dissertação (Mestrado) - Faculdade de Educação da Pontifícia Universidade Católica de São Paulo, São Paulo, 1997. 



\title{
Conselhos de Classe: avaliações, apreciações e percepções sobre meninos e meninas com implicações para as interações de gênero.
}

\author{
Daiane de Macedo Costa \\ Carmen Lúcia Guimarães de Mattos
}

Este capítulo argumenta como as avaliações, apreciações e percepções dos atores escolares, participantes em Conselhos de Classes (COCs) de escolas públicas do estado do Rio de Janeiro, informam sobre decisões a respeito da pertinência de conceitos distintos para meninos e meninas. Informa ainda como as percepções são mediadas por dicotomias sexuais e permeiam essas avaliações desconsiderando concepções de gênero que não comportam mais esta dicotomia. O capítulo trata, ainda, da análise das implicações que a atribuição de diferenças, características e comportamentos tipicamente percebidos como masculinos e femininos. Estas implicações trazem consequências para as atribuições desses conceitos, e assim, confirmam e perpetuam não somente essas características estereotipadas, como fragilizam as avaliações por se pautarem em subjetividades dos alunos em detrimento de suas características intelectuais e acadêmicas.

As análises selecionadas para este capítulo são derivadas do acervo em vídeo, textos, transcrições, notas de campo e observações in loco de 4 conselhos de classes de diferentes escolas da rede pública do Rio de Janeiro e áreas do Grande Rio de pesquisas desenvolvidas pelos pesquisadores do Núcleo de Etnografia em Educação (netEDU) da Universidade do Rio de Janeiro (UERJ). Foram elas Mattos (1996; 2008; 2010); e CASTRO (2006). 
Os COCs analisados reportam-se a observações e registros em vídeo dos anos de 1993, 2004, 2006 e 2010, cada ano com 4 reuniões, compondo cerca de 28 horas de vídeos e 1.200 páginas de transcrições, além de textos e anotações da equipe pesquisadora. A revisitação dos dados e observação de um COC, em 2010, foram realizadas por Costa (2010) sob a orientação de Mattos e suas análises são parte do trabalho de conclusão de curso em Pedagogia da Faculdade de Educação da UERJ. Este estudo inclui, ainda um dos objetivos da pesquisa Fracasso Escolar: gênero e pobreza (MATTOS, 2010).

Das análises produzidas depreendeu-se que as avaliações, apreciações e percepções dos atores participantes nos COCs eram diferentes para os meninos e as meninas resultando em implicações para as formas de organização das interações de gênero no âmbito da escola e nos resultados acadêmicos dos alunos. Estas análises evidenciaram os estereótipos de gênero com a apreciação positiva para características femininas dos alunos e negativas para as masculinas.

No que se referem a estas diferentes formas de percepções de papeis sociais atribuídos à meninos e meninas na escola e suas relações com o desempenho acadêmico estudos de autores como Connell (1995); Carvalho (2004; 2001); e Brito, (2006) mostram que existe uma tendência entre os professores em realizar caracterizações estereotipadas sobre esses papéis. Estas caracterizações, muitas vezes, levam a atribuição de características também estereotipadas que influenciam nas decisões dos professores quanto à interações de sala de aula e formas de avaliação de seus alunos. Dentre esses estereótipos incluem-se comentários de que os meninos são agitados, inquietos, desatentos, e as meninas como meigas, obedientes, estudiosas (BRITO, 2006).

Com enfoque nesses estudos procurou-se observar se durante os COCs essas diferenças se mantinham ou não, buscando entender como essas diferenças poderiam interferir na avaliação dos alunos mencionados durante as reuniões. 
Entretanto, para entender como a divisão de papéis sociais entre os alunos e as interações de gênero são apresentadas neste texto, faz-se necessário partir de concepções teóricas que orientam a construção desse conceito, assim como identificar qual é o conceito de gênero que serviu de base para os estudos realizados.

\section{Conceito de gênero}

Gênero e seu conceito, entendido como uma categoria de estudo tem sido, muito recentemente, considerado como tema de investigação relacionado à área de Educação no Brasil. Um estudo do tipo 'estado da arte' realizado por Machado (2000) aborda o tema e comenta sobre formulações teórico-metodológicas relacionadas ao conceito de gênero. Para a autora:

Gênero é uma categoria engendrada para se referir ao caráter fundante da construção cultural das diferenças sexuais, a tal ponto que as definições sociais das diferenças sexuais é que são interpretadas a partir das definições culturais de gênero. Gênero é assim uma categoria classificatória que, em princípio, pode metodologicamente ser o ponto de partida para desvendar as mais diferentes e diversas formas de as sociedades estabelecerem as relações sociais entre os sexos e circunscreverem cosmologicamente a pertinência da classificação de gênero. Este conceito pretende indagar metodologicamente sobre as formas simbólicas e culturais do engendramento social das relações sociais de sexo e de todas as formas em que a classificação do que se entende por masculino e feminino é pertinente e faz efeito sobre as mais diversas dimensões das diferentes sociedades e culturas (MACHADO, 2000, p. 5).

Os estudos sobre o conceito de gênero, na perspectiva de autores brasileiros, demonstram ainda que, em sua maioria, estão ancorados, inicialmente nas teorias feministas e que, a 
partir daí, criam independência teórica e corpo com significados próprios dos quais derivam as análises das relações de gênero. Entretanto, como aponta Matos (2008), as pesquisas dessas teorias, no campo de estudos e pesquisas sociais, assim como a área de confluência ainda carecem de consolidação e ampliação.

\begin{abstract}
É sabido que o pensamento feminista e de gênero tem nos oferecido ferramentas teóricas e reflexões metodológicas substantivas que já são responsáveis pela formação de algumas gerações de pensadores acadêmicos e de intelectuais. Penso que esse forte avanço no sentido da concretização da institucionalização desse novo campo, além de produzir a sua visibilização e reforçar a sua consolidação, vai contribuir concretamente nas muitas revisões e reelaborações de questões que são centrais na ciência política, na sociologia, na antropologia, na psicologia, na comunicação social etc. e que ainda não tivemos tempo suficiente para deflagrar. O espaço está conquistado e necessita ser definitivamente consolidado, mantido e até ampliado. (MATOS, 2008, p. 354-355).
\end{abstract}

Sobre essa mesma questão, Mattos (2009) em seu trabalho sobre gênero, argumenta que "no dia a dia falamos de gênero como uma palavra comum para o reconhecimento de homens ou mulheres, meninos ou meninas, mas [...] esse conceito não é de simples compreensão e pesquisa” (p.15). A autora aponta Connell como uma das pesquisadoras, no âmbito internacional, que mais tem contribuído para o entendimento do conceito de gênero, elegendo os estudos da socióloga para informar sobre este conceito, assim como nas análises produzidas neste capítulo. Gênero, de acordo com Connell,

[...] é uma forma de ordenação política e social, é a estrutura de relação social centrada na arena reprodutiva, um conjunto de práticas governadas por esta estrutura que traz distinções entre corpos dentro dos processos sociais. (CONNELL, 2002 p. 10). 
Connell (2005, p. 184) contribui ainda para as análises das interações de gênero e ordem de gênero ao explicar que existem arranjos convencionais ou ‘ordens de gênero' que variam de acordo com os padrões e diversidades de gênero na sociedade. Connell teoriza sobre as relações sociais e institucionais de gênero introduzindo os conceitos de: 'regimes de gênero' que são os modos de vida das pessoas no interior nas instituições; ‘configurações de gênero’ que são estruturas individuais manifestas das práticas de gênero nas diversas instituições sociais e 'relações de gênero' que são as diversas formas de interações entre gêneros orientadas por concepções de masculinidade e feminilidade. Connell exemplifica que a emergência de novas arenas nas relações sociais tomou uma escala mundial, criando novos padrões de 'relações de gênero', novos 'regimes de gênero’ e podem formar as bases para novas 'configurações de gênero’ e de masculinidade (MATTOS, 2011, p.16).

No Brasil, os estudos sobre gênero foram consolidados no final dos anos 1970 (FARAH, 2004, p. 47). Entretanto, quando relacionados à área da Educação esses estudos são raros ou pouco relevantes para as análises das relações intra-escolares.

De acordo com Bragança e Mattos (2009) o estudo sobre esta temática em Educação, em geral, parte da noção de naturalização das atribuições sociais de cada sexo e da dicotomia das relações entre os mesmos. As autoras, em estudo do tipo ‘estado do conhecimento' sobre o fracasso escolar, comentam com base nos trabalhos analisados, que

[...] para naturalizar as atribuições sociais
de cada sexo utiliza-se como fundamento
as diferenças sexuais mais perceptíveis. O
que significa dizer que o tratamento dado
às diferenças entre os desempenhos escola-
res e o comportamento, por exemplo, pode
ser explicado através do conceito de gênero
(BRAGANÇA; MATTOS, 2009, p. 8).

De fato, nos estudos sobre gênero e fracasso escolar, analisados pelas autoras, verificou-se uma tendência em utilizar conceitos oriundos de outros áreas do conhecimento e aplicálos diretamente à Educação. Embora, seja possível considerar 
as especificidades das relações intra e extra escolares como parte do processo dos conceitos e ideologias de gênero que permeiam o universo da escola na construção do conhecimento sobre a escola.

Assim, delineiam-se os fundamentos básicos que servirão para as análises que se seguem sobre as apreciações, percepções e interações escolares manifestas nas falas e comentários avaliativos de participantes dos COCs estudados.

\title{
Análises do rendimento escolar de alunos por membros dos COCs: avaliações, apreciações e percepções com implicações sobre interações de gênero.
}

As análises das reuniões de COCs estudadas revelaram que as relações e ordenações de gênero constituem-se como dimensões importantes para os professores avaliarem ou manifestarem apreciações relativas aos seus alunos. Estudos sobre COCs por Mattos (2006; 2009) ilustram como o fracasso escolar de alunos na Escola Básica, vem sendo explicado e justificado nos COCs. A autora aponta que:

\begin{abstract}
[...] essas investigações buscaram explicações para esse fenômeno, apontando justificativas como - as dificuldades dos alunos, situação socioeconômica e cultural das famílias, falta de instrumental técnico e teórico das escolas, mudanças frequentes no sistema escolar, ambiente social violento e pobre, processo pedagógico inadequado à cultura do aluno...” (MATTOS, 2009, p. 11).
\end{abstract}

As análises sobre os COCs teve com ponto inicial as avaliações dos alunos nessas reuniões. Estas análises consistiram em observar, registrar, diferenciar e aproximar, comentários realizados por professores e outros atores sociais da escola, sobre os alunos alvos das discussões. Cada COC revisitado em vídeo ou observado in loco teve as falas dos participantes transcritas ou reorganizadas em função da qualidade da imagem e do 
som. Após repetidas análises, optou-se por destacar as cenas nas quais os alunos eram mencionados contando-se a frequência para os meninos e para as meninas separadamente e qualificando a natureza destas avaliações (positivas, negativas ou nem positivas nem negativas).

O grupo total de alunos mencionado foi de 409 nos 4 COCs. Destes, 249 eram meninos, 160 meninas. O corresponde a 61\% de meninos e $39 \%$ de meninos para o total do grupo mencionado. Esses primeiros resultados situam uma diferença positiva para os meninos, isto é, meninos são mais frequentemente alvo de menções nas discussões dos COCs do que meninas.

Após esta etapa, verificou-se a natureza das menções avaliativas proferidas pelos membros dos COCs. Partindo-se novamente do total de alunos mencionados foram identificados três grupos por tipo de menção: 1) positivas, 2) negativas e, 3) nem positivas nem negativas. Entre as menções negativas 249 meninos, 182 receberam comentários negativos, o que corresponde a $73 \%$ do total de meninos. Das 160 meninas, 74 receberam comentários negativos o que corresponde a $46 \%$ do total das mesmas.

Quando os comentários eram positivos, as meninas superavam os meninos com 23 menções para os meninos (cerca de 9\% deles e 35 para as meninas (22\% do total).

Quando as menções e comentários não variavam positiva ou negativamente, isto é, eram pouco claros quanto a sua natureza ou referiam-se a práticas e costumes dos alunos, os números também favoreceram as meninas, embora com menor frequência. Neste tipo de menção 51 meninas receberam esse tipo de comentário enquanto 44 meninos foram mencionadas nesta categoria de análise, correspondendo, respectivamente aos percentuais de $32 \%$ do total das meninas e $18 \%$ dos meninos. Esses dados e seus percentuais ilustram os quadros I, II e II abaixo. Eles mostram com maior clareza as a frequência das menções, as suas diferentes características e variações de acordo com a cada sexo no Grupo de alunos que foram alvos dos COCs estudados. 


\section{Quadro I e II e III}


Fonte: 4 Conselhos de Classe dos anos de 1993, 2004, 2006 e 2010 - netEDU. 
Diferenças entre homens e mulheres orientadas pela divisão sexual são também estudadas por agências estatísticas como indicadores de variações resultados escolares. Não raro esses dados apontam que as mulheres têm vantagens sobre os homens quanto ao desempenho educacional (IBGE, 2008). Os resultados do IBGE para o ano de 2008 apontam que em todo 0 Brasil, entre as pessoas com 11 anos ou mais de estudos, as diferenças entre homens e mulheres é da ordem de $34,0 \%$ para os homens e $39,6 \%$ para as mulheres. No Rio de Janeiro, esta diferença é de $44,9 \%$ para os homens e 55,1\% para as mulheres.

Assim como as estatísticas do IBGE, pesquisas qualitativas como as de Carvalho, (2001, 2003, 2004), Brito (2006, 2004), Gilbert e Gilbert (1998), Connel et al., (1995) e Mattos (2010) também apontam que os meninos têm sido avaliados de forma diferente das meninas. Essa diferença tem se refletido na conclusão dos estudos, pois estes resultados demonstram que as mulheres conseguem terminar sua escolaridade em menos anos de estudo do que os homens.

As diferenças nas menções, comentários e avaliações dos membros dos COCs podem indicar uma das formas para explicar esses resultados. Mesmo que subjetivamente, elas indicam que a forma como os membros dos Conselhos de Classe discutem as relações entre os alunos, entre as professoras e seus alunos e até mesmo entre os alunos seus materiais escolares e tarefas podem contribuir para o avaliações menos favoráveis à atitudes e comportamentos masculinos e mais favoráveis a atitudes e comportamentos femininos, ou até mesmo objetivamente o fato de ser menino ou menina pode contar para menções diferenciadas e de valorações positivas para as meninas.

Uma das consequências advindas dessas atribuições de valores e dos tipos dos mesmos é que os meninos podem estar 'saindo' da escola antes de completarem os estudos e 'desistindo' de estudar durante o ano letivo. Na pior das hipóteses contribui para que mais meninos do que meninas sejam reprovados com maior frequência. 
Para ilustrar como estas menções e comentários podem ser realizadas, destacou-se do COC de 2006 as seguintes falas dos participantes:

Professora 1: Por que eu tenho um aluno que está faltando direto, há mais de um mês.

DIRETORA: Então tem que me comunicar pra ligar... (referindo-se a família e ao conselho tutelar)

Professora 2: Quem é o aluno?

Professora1: É, eu já comuniquei várias vezes.(significando que já havia ligado para a família)

Professora 2: Mas quem é o aluno?

Professora 2: Já falei até com o pessoal da direção, entendeu?

DIRETORA: Me entrega por escrito.

PROFESSORA 1: É Roger dos Santos

DIRETORA: Mas é falta justificada?!

Professora 2: Não, o percentual geral de falta eu não tenho. Só tenho por aluno. Específico por aluno.

DIRETORA: Professora 1, quem é, por favor? Professora 2: Roger dos Santos. É aquele caso, é, é, é... Márcia, que continua saindo todo dia ao meio-dia. A Mariana Silva, ela tem dificuldade em ficar com o Wellington. Aquele rapazinho, aquele aluno é que pega [...](referindo-se ao Roger dos Santos) e larga todos os dias ao meio-dia. Para ela eu não faço muita questão de ligar porque ela é uma boa aluna. Mas ele nunca quis nada com o estudo (referindo-se ao Roger dos Santos). Como eu cobro muito, ele deixou de vir às aulas, porque ele viu que ele não consegue acompanhar. Ele quer fazer bagunça e eu não aceito fazer bagunça na sala. Então eu acho que é até um problema, ele não aceitar ficar na escola (CIEP C, em COC de 06/10/2006). 
Na cena transcrita acima, os membros do COC constroem comentários para avaliar dois alunos Roger e Mariana que apresentaram 'problema' similar - falta à escola. Para a professora ambos estão com faltas acima do percentual permitido, além das faltas costumam sair mais cedo das aulas, desse modo, justifica que eles não conseguem acompanhar os conteúdos como os demais alunos da turma. A professora, solicita à diretora que comunique o 'problema' para a família de Roger, mas não considera da mesma forma a situação de Mariana, que é considerada uma 'boa aluna' e, que não precisa ter o seu caso comunicado aos seus pais. A professora justifica o bom comportamento de Mariana por ser considerada calma, meiga e quieta. Roger, ao contrário de Mariana é considerado pelo professora como bagunceiro, inquieto e 'vive aprontando na sala de aula'. Este exemplo ilustra as diferentes abordagens para o mesmo 'problema' nas avaliações durantes os COCs e implica que alunos e alunas sejam percebidos e avaliados diferentemente. A consequência dessas diferenciações é que os meninos podem estar correndo maior risco de fracasso acadêmico do que as meninas embora, os argumentos acima não contribuam para avaliar academicamente esses alunos.

De acordo com as pesquisas de Carvalho (2001; 2003; 2004) e Brito (2006) um "modelo" de aluno é ideologizado pela professora e este modelo é predominantemente feminino, comportado, passivo, quieto, controlado e cumpridor das normas escolares e tarefas propostas. Para as autoras, um 'aluno ideal' deveria ser independente, participativo, demonstrar facilidade para aprender, exibir rapidez de raciocínio, ser atento, concentrado, organizado e realizador das tarefas. Além dessas características, um 'bom aluno' tem apoio da família na realização das tarefas escolares e no atendimento as demandas da escola, dentre outros.

Em seus estudos Carvalho (idem) e Brito (idem) constataram que as meninas atendiam mais prontamente a esse perfil de aluno, eram mais participativas, tinham uma boa relação com a professora e recebiam maior atenção dela. Para Carvalho (2001)

[...] parece que não apenas se reconhece a existência de problemas escolares maiores entre os meninos, como também a imagem de 'bom aluno' estaria mais associada às 
meninas brancas (e orientais), talvez a um certo perfil de feminilidade. Pois, de acordo com as falas dessas professoras, o 'bom aluno' seria 'quem participa; quem consegue ter um elo legal com o grupo; quem se envolve com a escola'. E muitas meninas são descritas como boas alunas, mas sem essas características, o que ofuscaria suas qualidades (CARVALHO, 2001, p. 561).

Por serem as meninas consideradas, inteligentes, caprichosas, meigas, calmas, submissas e sossegadas, durante os COCs elas são pouco lembradas ou mesmo procuradas nas listas de 'problemas' a serem citados nessas reuniões. Enquanto os meninos, que são considerados agitados, barulhentos, levados, indisciplinados, dispersivos, dentre outros, são mais lembrados e notados nas lembranças dos 'problemas' o que resulta em prejuízo para as avaliações que recebem de seus professores (WALKERDINE, 1995).

Nos COCs estudados elencaram-se os argumentos, as justificativas e/ou temas associados as menções atribuídas aos alunos de modo a identificar padrões e discrepâncias que auxiliassem a compreender esta forma subjetiva de julgamento. A frequência dessas menções, que se traduziam em avaliações, foi verificada e o resultado foi descrito nos quadros IV e V ilustrando a natureza dos argumentos utilizados pelos membros dos COCs para avaliar meninos e meninas:

\section{Quadro IV}

\section{Natureza dos argumentos paradas avaliações} dos meninos
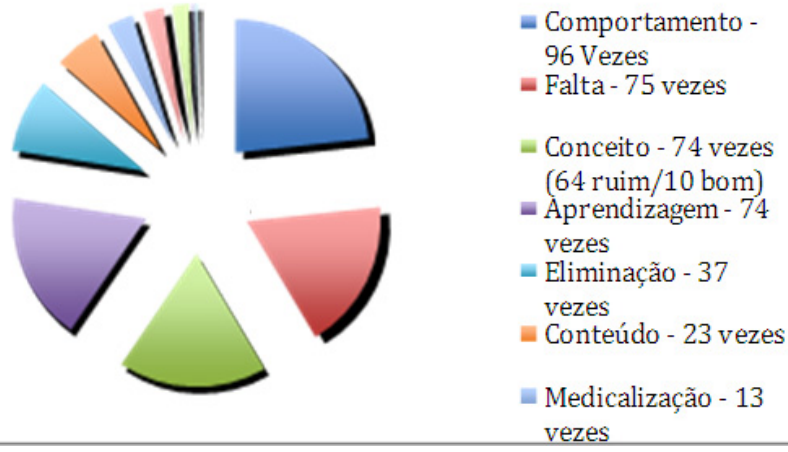
Quadros V

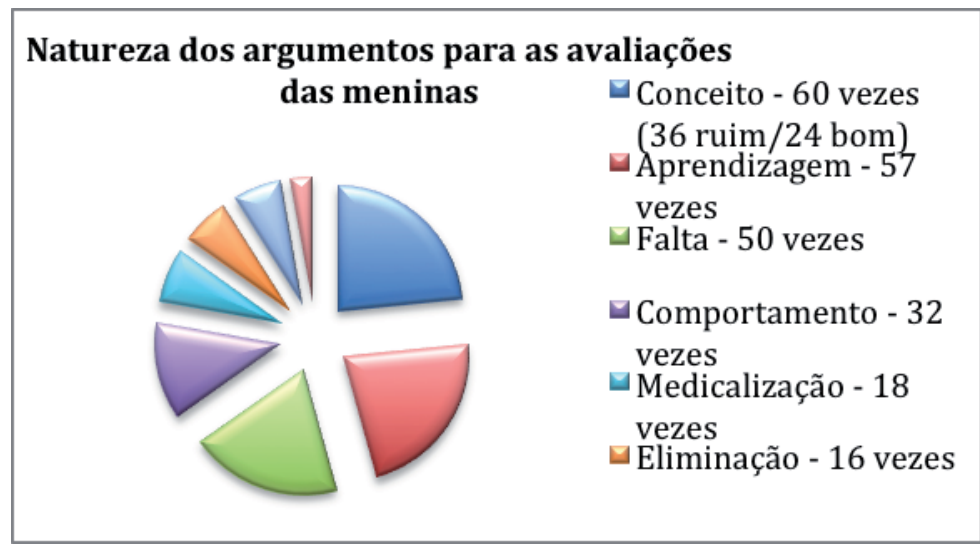

Fonte: 4 Conselhos de Classe dos anos de 1993, 2004, 2006 e 2010 - netEDU.

Os quadros IV e V demonstram quais os argumentos utilizados para consubstanciar as avaliações de meninos e meninas e o motivo pelo qual eles foram considerados de natureza positiva ou negativa. No quadro dos meninos, o comportamento e as faltas são considerados mais relevantes que o conceito e a aprendizagem que, por sua vez, situam-se como mais relevantes entre as meninas.

A aprendizagem no quadro dos meninos está em $4^{\circ}$ posição, enquanto o comportando está em $1^{\circ}$, as faltas em $2^{\circ}$ e 0 'conceito' - que significa a nota obtida em provas - em $3^{\circ}$, lugar. $\mathrm{O}$ comportamento mencionado pelos membros do COC esta relacionado à indisciplina, desobediência à professora e à todas as formas de transgressão das regras estabelecidas para o funcionamento da sala de aula e da escola em geral.

A fala dos participantes nos conselhos de 2004 confirmam os resultados registrados no quadros anteriores. A cena com a seguinte sequencia, transcrita abaixo.

COORDENADORA PEDAGÓGICA: [...] Que nem o Maicon, [...] não faz as coisas. [...] Ele é muito chato. Eu vou compartilhar o sentimento com vocês. 
PROFESSORA RAQUEL: Ele é um dos piores. Quando até os piores estão fazendo trabalho ele vai lá

PROFESSORA ANALICE: Agora, a Dora e o Oscar faltam e têm o péssimo hábito de comer dentro da sala; você abre a mochila, tem um pão e um tênis junto, vem de chinelo, traz o pão e o tênis junto, eles entram sempre muito depois, pelo menos uma hora depois da turma, aí eles sentam, juntos, né, aí fazem assim (A professora abaixa a cabeça debaixo da mesa para demonstrar como os alunos comem).

PROFESSORA HELENA: Outro dia eu encontrei os dois, às 9 horas da noite andando a pé, ali embaixo, aí eu perguntei: Vocês não têm ido à aula, o que tá acontecendo? - A gente tamos doente, tia Helena; aí falei - Mas eu acho que vocês estão melhores, amanhã vocês já podem ir pra escola, a gente tá com saudades, mas não apareceram.

PROFESSORA RAQUEL: Aí quando vêm trazem todos os brinquedos de casa e juntam com o Fábio, que já é uma delicadeza de criança, (fala com ironia significado contrário) aí você imagina (COCs da E. M. Cesário, nos dias 30/04 e 22/07 de 2004).

No contexto das argumentações o aluno Maicon, de acordo com a professora, é percebido como chato, por atrapalhar durantes as aulas os outros alunos demonstrando comportamento indisciplinado e inadequado. Ela argumenta que ele tenta chamar a atenção da professora saindo do seu lugar, mexendo-se, não realizando as tarefas recomendadas e 'perturbando' os outros alunos. Enquanto os alunos Dora e Oscar são descritos como portadores de hábitos diferentes dos outros alunos pois, comiam durante as aulas e não se atinham aos horários de entrada e saída das aulas e da escola. Eles não seguiam as normas de horário de entrada e saída, faltavam em demasia e eram indisciplinados. 
O que essas falas têm em comum é que as características de transgressão às normas de sala de aula, de não aceitação da rotina escolar foram marcantes para as professoras que mencionaram o fato no conselho de classe antes da avaliação da aprendizagem desses alunos. A falas dessas professora demonstram que outras características se sobrepõem à aprendizagem dos alunos no momento da avaliação nos COCs como foi mencionado no caso acima sobre comer na sala de aula, chegar atrasado, misturar calçado com alimentos, ou seja, toda uma série de questionamentos são feitos antes de chegar à produção escolar do aluno.

Por sua vez, as meninas, por apresentarem um comportamento mais próximo do "modelo de aluno" esperado pela escola - mesmo que apresentem passividade diante das tarefas propostas - elas transgridem menos as normas da escola, recebem avaliações centradas no conceito, na aprendizagem, no comportamento e nas faltas pela ordem de menções pelas professoras. Elas são menos consideradas nas apreciações do que dos meninos. Pode-se verificar, que as ponderações atribuídas às meninas são, na sua grande maioria, fechadas, sem muito conflito, como pode ser unificado nas falas dos conselhos abaixo:

PROFESSORA: Fernanda Rozas, bola; [significa conceito B] (...) Tatiana, B.; (...) Paula, bola; (...) Fávia, bola; (...) Tamara, bola; (...) Liliane, bola; (...): Adriana bola; (...) Vanessa, bola (COC da E. M. Lázaro dia 30/09/2003).

PROFESSORA MARTA: Agora, só pra concluir, então, aqui, os alunos que se destacam positivamente são os meus alunos que têm conceito O e MB: Anita, Douglas, Catarina, Julimar, Caio, que é da residência, [significa que o aluno foi indicado pelo Conselho Tutelar para morar na escola] Melissa e Gleice (COC do CIEP C em de 06/10/2006).

PROFESSORA ADELINA: Brenda Cristina leu bem. 
COORDENADORA PEDAGÓGICA: A Carla também (COC do CIEP ÍCARO dia 14/07/2004).

PROFESSORA DA TURMA 302: Tem uns que sabem demais, tem outros que não sabem nada, a Cristiane, a Bruna. Agora tem outros que não sabem nada, o caso do (...), do Cristian não sabe nem ler direito (COC do CIEP ÍCARO dia 22/07/2004).

PROFESSORA ADELINA: A Juliana Medeiros já era uma boa aluna, só faltava direcionar. A Eduarda era "I", mas ela melhorou muito. Ela não estava nem fazendo as tarefas.

PROFESSORA SILVANA: Agora que a gente descobriu que ela tem uma letra bonita.

COORDENADORA PEDAGÓGICA: Eu estava surpresa com a Jéssica, porque ela sempre foi boa aluna (COC do CIEP ÍCARO dia 14/07/2004).

As menções às meninas, citadas acima, demonstraram que os elogios prevalecem entre as argumentações para a atribuição de conceitos, pois a percepção sobre o comportamento está pouco presente nestas argumentações. Neste quesito é dito que as meninas não dão muito trabalho. Da mesma forma as alunas não são mencionadas pela aprendizagem, embora não sejam consideradas pelas professores como "inteligentes". Esses dados são consubstanciados nos resultados das pesquisas de Carvalho (2003) que apontam que

as professoras têm me indicado é que os 'bons mesmos', os ótimos alunos, são meninos. Quase sempre quando me descrevem suas classes, elas colocam os meninos nos dois pólos, o dos 'excelentes' e o dos 'muito complicados', que têm muita dificuldade. E as meninas permanecem no círculo mediano: não são tão brilhantes, mas também não dão tanto problema. Isso mostra que há um grupo de meninos que tem conseguido articular algum tipo de afirmação da sua masculinidade com um desempenho escolar 
muito positivo do ponto de vista das professoras; indica também que precisamos ainda entender os múltiplos conceitos de masculinidade que circulam entre os nossos alunos (CARVALHO, 2003, p. 189).

Constatou-se ainda que nos dados analisados as argumentação utilizadas para conceituar os meninos pelos membros dos COCs, quando elogiosas, são permeadas por expressões mais comumente utilizadas para elogiar as meninas.

PROFESSORA: O Rubens é um aluno ótimo que nós temos na sala, né? Responsável, o melhor dos alunos! É... O pai dele veio de manhã aqui...

- Professora, professora, o Rubens veio? Falei assim - Veio. Ah, deixa eu dar uma olhadinha pra conversar com ele. Aí eu falei... Aí eu fiquei pensando, né? Provavelmente não moram juntos pai e mãe, né? Aí fiquei prestando atenção. Ai ele virou e falou assim, - Sabe, professora, tava tão preocupado que a mãe dele, minha esposa, ela tá internada e hoje ele ficou o dia todo sozinho, dormiu sozinho com o irmão de 10 anos... - É... e eu fiquei preocupada. Então, quer dizer, achei interessante, né? A preocupação no dia! Eu acho que isso parte dos pais mesmo. Melhor aluno da turma, a mãe está internada e ele que ficou cuidando do irmão de 10 anos (CIEP ÍCARO, entrevista com a professora).

PROFESSORA 1: Ah, falar do Patrick...

PROFESSORA 2: O Patrick é A;

PROFESSORA 1: Ah, Patrick é...

PROFESSORA 2: O Patrick é muito bom...

DIRETORA: O Patrick é aquele que frequenta a turma da... Elizabeth (COC da E. E. São Sebastião, em 1993). 
Expressões como 'ótimo aluno', 'o melhor dos alunos', 'muito bom', 'responsável', confirmam o que Carvalho (2003) demonstrou no resultado de sua pesquisa. Apesar de as meninas serem mais elogiadas que os meninos, elas são medianas, não são tão brilhantes quanto um ou outro menino que se encontra nessa posição. As professoras demonstram satisfação em ter alunos que se destacam entre os demais. Entretanto, a realidade é que são poucos os meninos que se encontram em posições favoráveis de destaque, a grande maioria, são os meninos tidos como 'complicados', 'difíceis', 'impossíveis'.

Entre os argumentos utilizados pelos membros dos COCs uma explicação para a diferença entre os sexos está no fato de que as meninas seriam consideradas mais aptas à escola pois esta possui uma tradição feminina (CARVALHO, 2003). Isso foi observado quando meninos e meninas, são mencionados em comportamento, disciplinados ou não, evidenciando posições diferentes entre os sexos. Este tipo de menção também está relacionada a uma hipótese francesa chamada "ofício de aluno", adotada por Perrenoud (2002, p.21) e utilizada também no Brasil por Silva et. al. (1999) ela diz:

Há que se considerar, ainda, que, ao ingressar na escola, a criança já traz uma representação dos papéis de aprendiz e professor, de homem e de mulher vivenciados nas relações familiares. Tal representação contempla uma diferença importante que é a de aluno e aluna. O que, por exemplo, os pais esperam de seu filho para que seja considerado um bom aluno? O que, para o pai, é mais significativo, que seu filho traga boas notas e um parecer de aluno "bem-comportado" ou que as notas sejam sofríveis ou até insuficientes, mas que ele se saia bem como aquele que "não leva desaforo para casa” e, por isso, não é chamado de maricas? (SILVA et al., 1999, p.222).

As implicações para o exercício deste ofício de aluno esteve representado em muitas das avaliações realizadas nos COCs analisados nesse estudo quando os professores indicam diferenças nas formas de mencionar os resultados escolares de meninos e meninas. 


\section{Considerações finais}

Pelos dados e pressupostos teóricos (MATTOS, 2010; CONNELL, 1995, 2000, 2008; CARVALHO, 2001, 2004; BRITO, 2006) apresentados nesse estudo, pode-se inferir sobre a existência de uma larga vantagem para os meninos entre as avaliações negativas, enquanto em todos os tipos de avaliação as meninas foram mais bem avaliadas; que os meninos cooperam menos do que as meninas e, desse modo, recebem avaliações negativas relativas ao comportamento inadequado em sala de aula.

Contrário a estes argumentos pressupõe-se que, através dos estudos realizados sobre o fracasso escolar (MATTOS, 2009), na percepção dos alunos eles não são diferentes das meninas. Os dados destas pesquisas leva a conclusão de que os meninos ao se comportarem desta forma em sala de aula e na escola, demonstram não se 'conformarem' com o tipo de aula oferecido. Agem no sentido de subverterem a ordem local, enquanto as meninas 'cooperam mais' e são menos argumentativas quanto a instrução que recebem.

Portanto, o fato de serem avaliados com notas mais baixas, serem mais reprovados, dentre outras características negativas, não sugere que eles sejam 'os piores', mas ao contrário, talvez possa ser uma indicação de que sejam 'melhores', visto que as meninas agem passivamente em relação ao 'tipo de aula quer recebem de modo a obter 'boas' menções. A qualidade da educação brasileira, de um modo geral, é considerada pouco qualificada para receber e formar bons alunos. Seria o caso de repensar as condições em que meninos e meninas vem sendo formados para então promover avaliações, especialmente nos COCs, que apresentassem argumentos relacionados aos processos educacionais como um todo e não somente quanto a bons e maus alunos e alunas. Entende-se que dessa forma poderia ser promovida uma mudança quanto os argumentos relacionados àqueles considerados maus alunos. 


\section{Referências}

BRASIL. Ministério de Educação e do Desporto. Referencial curricular nacional para a educação infantil. Brasília, DF: MEC, 1998.

BRASIL. Secretaria de Educação Fundamental. Parâmetros curriculares nacionais. Secretaria de Educação Fundamental. Brasília : MEC/SEF, 1997.

BRITO, R. S. Masculinidades e feminilidades: implicações para o fracasso /sucesso escolar de meninos e meninas nas séries iniciais. In: Anais 27 ${ }^{a}$ Reunião Anual da Anped, Caxambu - MG, 2004.

BRITO, $\mathrm{R}$ dos $\mathrm{S}$. Intricada trama de masculinidades e feminilidades: fracasso escolar de meninos. Cadernos de Pesquisa, v. 36, . 127, p. 129-149, jan./ abr., 2006.

CARVALHO, M. P. D. Mau aluno, boa aluna? Como as professoras avaliam meninos e meninas. Revista Estudos Feministas, v. 9, n. 2, p. 554-574, 2001.

CARVALHO, M. P. D. Quem são os meninos que fracassam na escola? Cadernos de Pesquisa, São Paulo, v. 34, n. 121, p. 11-40, jan./abr. 2004.

CARVALHO, M. P. D. Sucesso e fracasso escolar: uma questão de gênero. Educação e Pesquisa. São Paulo, v. 29, nº.1, p. 185-193, jan./jun, 2003.

CONNELL, R. W. The man and the boys. Cambridge: Polity Press, 2000.

CONNELL, R. W...[et.al.]. Estabelecendo a diferença: escolas, famílias e divisão social. $7^{\text {a}}$ ed. Porto Alegre: Artes Médicas, 1995.

CONNELL, R. W. Gender. $1^{\text {a }}$ ed. Cambridge: Polity Press, 2002.

FARAH, M. F. S. Gênero e políticas públicas. Estudos Feministas. Florianópolis, v. 1, nº 12, p. 47-71, jan/abr., 2004. 
FINCO, D. Socialização de gênero na educação infantil. Ciênc. let., Porto Alegre, n. 43, p. 261-274, jan./jun., 2008.

GILBERT, R; GILBERT, P. Masculinity goes to school. London: Routledge, 1998.

IBGE. PNAD - Pesquisa Nacional por Amostra de Domicílio, 2008.

MACHADO, L. Z. Perspectivas em confronto: relações de gênero ou patriarcado contemporâneo? Série Antropologia, $n^{\circ} 284$, Brasília, 2000.

MATTOS, C. L. G. de. Etnografia na Escola: duas décadas de pesquisa sobre o fracasso escolar no ensino fundamental. In: MATTOS, C. L. G. de; FONTOURA, H. A. da. Etnografia e Educação: relatos de Pesquisa. Rio de Janeiro: Eduerj, 2009.

MATTOS, C. L. G. de. Gênero e pobreza: práticas, políticas e teorias educacionais - imagens de escolas. Projeto de Pesquisa. Prociencia/UERJ: Rio de Janeiro, 2009.

MATTOS, C. L. G. de. O conselho de classe e a construção do fracasso escolar. Educação e Pesquisa, São Paulo, v. 31, nº 2, p. 215-228, maio/ago., 2005.

MATTOS, C. L. G. de.; CASTRO, P. A. de. Fracasso escolar: gênero e pobreza. Relatório de Pesquisa, CNPq/Edital Ciências Humanas: Brasília, DF, Julho 2010.

MATTOS, C. L. G. de.; CASTRO, P. A. de. Fracasso escolar: gênero e pobreza no Brasil. Relatório de Pesquisa, CNPq/Edital Universal: Brasília, DF, 2010.

MATTOS, C. L. G. de; CASTRO, P. A. de; MACIEL, S. A. Gênero e pobreza: a situação educacional dos filhos e filhas de mulheres presas e dos filhos e filhas de jovens infratoras no Estado do Rio de Janeiro. Relatório de Pesquisa. CNPq, Brasília, DF, 2011. 
MATTOS, C. L. G. de; BRAGANÇA, G. A. A produção do saber nas pesquisas sobre o fracasso escolar (1996-2007): um recorte de gênero. Anais do IX Encontro de Pesquisa em Educação da Região Sudeste. São Carlos - SP, 2009.

PERRENOUD, P. $O$ ofício de aluno e sentido do trabalho escolar. Lisboa: Porto Editora, 2002.

SILVA, C. D. et al. Meninas bem-comportadas, boas alunas, meninos inteligentes, mas indisciplinados. Cadernos de Pesquisa, São Paulo, n. 107, p. 207-225, jul. 1999.

WALKERDINE, V. O raciocínio em tempos pós-modernos.

Educação e Realidade. Porto Alegre, n.20, v.2, jul./dez., 1995. 


\title{
O absenteísmo escolar e sua regulamentação
}

\author{
Suziane Santana de Vasconcellos \\ Carmen Lucia Guimarães de Mattos
}

Como parte da pesquisa Fracasso escolar: gênero e pobreza (MATTOS, 2008-2010) este capítulo apresenta resultados de trabalho final de curso $^{1}$ desenvolvidos no interior do Grupo de Pesquisa Etnografia e Exclusão do Núcleo de Etnografia em Educação (netEDU/ ProPEd/UERJ). É uma pesquisa de abordagem etnográfica que observou durante o ano letivo de 2008 uma classe da $1^{\text {a }}$ série do ensino fundamental que era constituída por alunos e alunas repetentes e multirepetentes.

Na classe de repetentes da turma C, na Escola Municipal João Pedro II, a falta de alunos na sala de aula é um tema recorrente e este capítulo apresenta os estudos que abordam o absenteísmo de alunos (IRELAND, 2007; SOUSA, 2003; NOGUEIRA, 2006; SILVEIRA, 2007; VIANA et al 2007; SOUSA, 2004; CASTELEIRO, 2007); a regulamentação sobre o absenteísmo e suas implicações para o aluno; além dos dados empíricos que ilustram com as falas dos participantes os argumentos sobre o absenteísmo entre os alunos.

O termo absenteísmo é encontrado usualmente na área de administração e é empregado para avaliar a rotatividade de funcionários nas empresas, determinando assim o desempenho

1 Este capítulo foi modificado para fins de publicação neste livro, originalmente é parte da dissertação da mestrado intitulada "A classe de repetentes: um estudo etnográfico" defendida em 2010 pela autora e orientada pela co-autora. 
dos mesmos. Está associado ainda a possíveis problemas em um determinado segmento da empresa, espaços em que o absenteísmo é mais frequente entre os funcionários, servindo para identificar as falhas e os ajustes necessários ao segmento.

Embora ainda pouco comum no contexto educacional, esta expressão vem se tornando cada vez mais frequente na literatura da área. Não raro, o termo é utilizado como sinônimo para 'falta às aulas'. Entretanto, um olhar mais cuidadoso sobre o conceito revela que existem variações para o entendimento do mesmo.

De acordo com Faro (2007) o absenteísmo escolar

constitui por si um problema individual grave na medida em que representa um entrave ao sucesso educativo de cada aluno. Pode conduzir mais tarde a situações de abandono escolar e a situações de delinqüência e exclusão social levando o problema para a esfera da questão social. [...] O absenteísmo escolar, [é] entendido como a falta injustificada de comparecimento às aulas por parte de um aluno (REID, 1981). [...] quando estas faltas de assistência se sucedem de forma reiterada ou se prolongam no tempo, o ritmo de aprendizagem do aluno é afetado e, inevitavelmente, começam a surgir problemas de insucesso escolar que, se não forem solucionados rapidamente, podem conduzir a situações de abandono. [... ] o absenteísmo escolar [...] constitui um dos principais fatores que contribui para o aparecimento de situações de marginalidade, delinquência e analfabetismo (GALLOWAY; SEYD; BALL, 1978). [...] quando o absenteísmo escolar obedece a fatores de tipo social ou familiar, como ocorre na maioria dos casos, então a solução para o problema converte-se num assunto complexo e, por vezes, de difícil solução (Orr, 1987). [...] um aluno que convive num seio de uma família desestruturada, ou imerso num ambiente social onde coexistem problemas sociais graves, como dependências, 
prostituição, delinquência, miséria, tem uma maior probabilidade de vir a engrossar as estatísticas do absenteísmo escolar (FORTIN; ROYER; POTVIN; MARCOTTE; JOLY, 2001). Uma criança ou um adolescente, que tem que se preocupar diariamente por conseguir o seu próprio sustento ou que se desenvolve num ambiente onde o nível educativo ou formativo da pessoa não é valorizado, dificilmente pode sentir-se atraído pela escola, que não oferece resultados tangíveis em curto prazo (FORQUIN, 1985) [...] a maioria destes alunos provêem de ambientes marginais ou de zonas urbanas deprimidas e sofrem graves carências econômicas e sociais (FARO, 2007, p. 6).

Faro (2007) elenca fatores intrínsecos e extrínsecos que podem levar o aluno ao absenteísmo. Dentre os fatores intrínsecos são citados: a preparação acadêmica anterior, a saúde física e o equilíbrio pessoal, o grau de integração na escola e a satisfação acadêmica, as condutas problemáticas, o profundo desinteresse, dentre outros (idem p.12). Os extrínsecos, explica o autor, de acordo com Gilly (1986 apud FARO, 2007) envolvem:

Variáveis familiares: nível socioeconômico, cultural e acadêmico dos progenitores; qualidade da relação entre os membros da família, valor atribuído à escolaridade e ao trabalho, valores morais, interesse dos pais pela educação dos filhos;

Variáveis atribuíveis à dinâmica da própria escola: sistema organizativo e de coordenação, estilos de ensino dos professores, clima de convivência, ambiente percepcionado na turma e fora dela;

Variáveis referentes ao currículo: se este se apresenta atrativo na sua formulação, na sua prática, etc. (GILLY, 1986, apud FARO, 2007, p. 12). 
O absenteísmo escolar vem sendo citado, inúmeras vezes, por Abramovay, em seus estudos sobre a violência escolar (ABRAMOVAY; RUAS, 2002). Nesse contexto a autora destaca a origem do termo, definido a partir da área de administração, associando o absenteísmo às violências da e na escola para com os alunos; a dificuldade de registro e controle pelos professores e autoridades sobre as faltas às aulas; a preconceituosa correlação do problema à família do aluno e a relação direta entre faltas escolares e fracasso escolar, delinquência e pobreza. A autora afirma que:

riscos relacionados à violência simbólica, dos quais poderíamos destacar o absenteísmo e fatores relacionados ao fracasso escolar, tais como o abandono da escola. É importante ressaltar que o absenteísmo frente a uma condição de violência social manifesta, também se associa a fatores de desigualdade social, [...] Sob o ponto de vista administrativo, o absenteísmo vem sendo definido (CHOUQUET, 1993) como um comportamento centrado na repetição de faltas voluntárias às aulas. No caso brasileiro, o Ministério da Educação trabalha a questão de forma aleatória considerando absenteístas, os alunos com determinado número de falta às aulas registradas pelos diários de classe dos professores. [...] Devido às dificuldades sistemáticas de mensurar a incidência e manifestações do absenteísmo dentro da escola e suas possíveis correlações com o fracasso escolar, tem-se estabelecido uma tendência preconceituosa em buscar na família, em especial famílias de baixa renda, os verdadeiros culpados por seus maiores níveis de incidência, reproduzindo assim perspectivas simplistas entre pobreza, delinquência juvenil e fracasso escolar (ABRAMOVAY s/d, p. 13-14).

Uma pesquisa coordenada por Ireland (2007) aponta os desafios enfrentados pelas escolas em todo o Brasil para ensinar seus alunos a ler e escrever. Em sua apresentação o trabalho 
questiona a finalidade da reprovação e aponta a desistência, a repetição e o absenteísmo como parte do 'drama brasileiro' para escolarizar seus alunos. A autora questiona:

Como se poderá entender que uma criança de seis anos de idade, no atual Ensino Fundamental de nove anos, seja uma fracassada ao fim da primeira série? Como se poderá explicar a essa criança, aos seus pais e responsáveis e à sociedade o significado da reprovação, do insucesso e da necessidade de repetir todo o ano de estudos realizados? Esta é uma das faces do drama brasileiro que se manifesta, entre outros aspectos, na desistência dos alunos ao longo dos períodos letivos ou entre eles, na repetição e na perseverança dos estudos, em média por longo tempo, e pelo absenteísmo (IRELAND, 2007, p. 17).

Mais adiante a autora associa a reprovação, a evasão e o absenteísmo entre os alunos, como um indicador de exclusão social:

Sabe-se que dificuldades detectadas na educação básica estão relacionadas com problemas que vão se acumulando desde o início da escolarização de muitas crianças, aqui e ali reveladas por sinais como a reprovação, o abandono da escola e o absenteísmo, fenômenos esses que já se sabe serem também associados ao modo de funcionamento da escola e da sociedade que a comporta. Mas, na medida em que o aluno não consegue desenvolver, ao longo de sua trajetória escolar, determinadas habilidades que lhe permitam enfrentar as tarefas e exigências da sociedade e do mundo do trabalho contemporâneos, ele provavelmente será excluído da sociedade. Nesse sentido, a melhora do desempenho escolar tem uma conotação que vai muito além dos muros da escola (idem, p. 19). 
Portanto, o absenteísmo entre alunos e professores revelase como uma das dificuldades enfrentadas pelas escolas. Mecanismos de controle, tanto para os professores quanto para os alunos, não tem garantido a frequência desses alunos, nem um maior compromisso profissional por parte dos professores em relação às suas faltas. Entretanto, enquanto o absenteísmo entre os professores é interpretado pela escola como um problema a ser resolvido pelos sistemas de ensino (federal, estadual e municipal), entre os alunos, ele é entendido como um problema a ser resolvido pela escola, pelos pais e por instâncias do poder público judiciário.

A impressão que se tem é a de que a presença dos alunos nas escolas, por si só, poderia garantir a sua escolarização, independentemente da presença do professor. Os diversos mecanismos que regulamentam o absenteísmo entre os alunos têm sido impostos à escola, sem que a mesma possa efetivamente atuar para evitar que os alunos faltem às aulas. A mais recente forma de controle está associada à política assistencial, adotada com as famílias de baixa renda, maioria nas escolas públicas - a bolsa família. Esta política social tem como condicionante a presença do aluno, nesse caso, atrelada ao recebimento da bolsa família pelo seu responsável.

O que observamos, de modo geral, nas escolas pesquisadas pelo netEDU, em 2009 e 2010, é o fato de que as escolas estão 'maquiando' os dados de frequência de seus alunos, atribuindo-lhes uma frequência total, independente da registrada pelos professores. Como justificativa, o argumento é de que "não podem agravar ainda mais a situação de pobreza dessas famílias". A frequência assim declarada, nada tem a ver com a real presença do aluno às aulas, mostrando, mais uma vez, que políticas assistenciais inseridas no interior da escola contribuem para demonstrar a sua incompetência e fomentar um sistema de 'faz de conta', comumente atribuído à área da Educação.

Esta temática não é preocupação deste capítulo, foi citada apenas a título de ilustração, para salientar o modo como são exercidos os mecanismos de controle sobre o absenteísmo 
(faltas de alunos), assim como os 'novos' processos de avaliação, e/ou a qualidade das aulas oferecidas às classes menos favorecidas que frequentam as escolas públicas.

Isto evidencia, mais uma vez, que a escola ainda não se deu conta da entrada deste grupo socialmente desfavorecido. Ela continua a perpetuar um ideário elitista, de forma alienante, no qual interpreta o aluno e suas famílias como sendo os culpados pelas dificuldades e desencontros culturais existentes na mesma.

\section{Absenteísmo e instâncias reguladoras}

Estabelecida a relação entre o absenteísmo escolar, a repetência, a delinquência juvenil, o fracasso escolar e a exclusão educacional, podemos questionar: o que está acontecendo no universo escolar para prevenir ou inibir o absenteísmo entre os alunos?

Sobre o absenteísmo de alunos, a legislação brasileira estabelece, de acordo com a constituição, em seu Artigo 208, parágrafo $3^{\circ}$ que: "compete ao poder público recensear os educandos no Ensino Fundamental, fazer-lhes a chamada e zelar, junto aos pais ou responsáveis, pela frequência à escola" (BRASIL, 1988).

O Estatuto da Criança e do Adolescente (ECA), criado dois anos depois da carta constitucional, insere os Conselhos Tutelares Municipais (CTs) como instâncias a serem "comunicadas", em casos de faltas "injustificadas" e "elevados" níveis de repetência, uma vez "esgotados" os recursos escolares (BRASIL, 1990), o texto do ECA é o seguinte:

VII - Atendimento no Ensino Fundamental, através de programas suplementares de material didático-escolar, transporte, alimentação e assistência à saúde.

$\S 3^{\circ}$ Compete ao poder público recensear os educandos no Ensino Fundamental, fazerlhes a chamada e zelar, junto aos pais ou responsável, pela frequência à escola. 
Art. 55. Os pais ou responsável têm a obrigação de matricular seus filhos ou pupilos na rede regular de ensino.

Art. 56. Os dirigentes de estabelecimentos

de Ensino Fundamental comunicarão ao Conselho Tutelar os casos de:

I - maus-tratos envolvendo seus alunos;

II - reiteração de faltas injustificadas e de evasão escolar, esgotados os recursos escolares;

III - elevados níveis de repetência.

Ambos os textos, da carta magna e do ECA foram incorporados à Lei de Diretrizes e Bases da Educação Nacional, em 1996.

Lei $n^{\circ}$ 9.394/96.

Art. 24 - A educação básica, nos níveis fundamental e médio, será organizada de acordo com as seguintes regras comuns:

I - A carga horária mínima anual será de oitocentas horas, distribuídas por um mínimo de duzentos dias de efetivo trabalho escolar, excluído o tempo reservado aos exames finais, quando houver (BRASIL, 1996).

VI - o controle de frequência fica a cargo da escola, conforme o disposto no seu regimento e nas normas do respectivo sistema de ensino, exigida a frequência mínima de setenta e cinco por cento do total de horas letivas para aprovação;

Art. 12. Os estabelecimentos de ensino, respeitadas as normas comuns e as do seu sistema de ensino, terão a incumbência de:

VII - informar pai e mãe, conviventes ou não com seus filhos, e, se for o caso, os responsáveis legais, sobre a freqüência e rendimento dos alunos, bem como sobre a execução da proposta pedagógica da escola; (Redação dada a Lei $n^{\circ}$ 9.394/96 pela Lei $n^{\circ} 12.013$, de 2009). 
VIII - notificar ao Conselho Tutelar do Município, ao juiz competente da Comarca e ao respectivo representante do Ministério Público a relação dos alunos que apresentem quantidade de faltas acima de cinqüenta por cento do percentual permitido em lei. (Redação dada a Lei $n^{\circ}$ 9.394/96 pela lei 10.287/2001).

Portanto, para a aprovação, fica estabelecida a exigência mínima de setenta e cinco por cento (75\%) de frequência, do total de oitocentas (800) horas, ou duzentos (200) dias letivos. Isso dá ao aluno o direito de faltar às aulas até o limite de vinte e cinco por cento (25\%) do referido total, isto é, duzentas (200) horas ou cinquenta (50) dias letivos. Assim, é admitida para a aprovação, a frequência mínima de setenta e cinco (75\%) da frequência total às aulas e das demais atividades programadas pela escola. Da mesma forma, faltar cinquenta (50) dias letivos ou duzentas (200) horas de atividades implica na reprovação automática do aluno.

Entretanto, até atingir este limite, a lei determina que medidas sejam tomadas pela escola para prevenir a ausência do aluno. $\mathrm{O}$ controle da frequência dos alunos é uma delas, que geralmente ocorre durante o ano letivo. Bimestralmente, professores e dirigentes escolares discutem em Conselhos de Classe (COC) a frequência dos alunos. No COC verificamos que um tempo considerável da reunião é dedicado às análises da frequência de cada aluno e das possíveis implicações de suas faltas.

A atuação dos COCs dentro das escolas é regulamentada pelo Regimento Escolar. Neste caso, pela Secretaria Municipal de Educação do Rio de Janeiro (SME/RJ), que editou em abril deste ano (2010) a resolução que dispõe sobre o Regimento Escolar Básico de sua rede de ensino. O novo regimento, em seu Título V, regulamenta a organização pedagógica. No Capítulo VI trata da promoção e da frequência e logo a seguir, no Capítulo VII, trata do Conselho de Classe, dispondo sobre o seu funcionamento. $\mathrm{O}$ texto diz:

Art. 45. A promoção dos alunos dar-seá quando atingidos os padrões mínimos estabelecidos para cada série, relativos ao aproveitamento escolar e à frequência. 
Art. 46. O Conselho de Classe é o espaço democrático de tomada de decisões acerca do Projeto Político-Pedagógico da Escola, do fazer pedagógico na sala de aula e do desenvolvimento da aprendizagem do aluno.

Art. 47. Caberá ao Conselho de Classe:

I - realizar a auto-avaliação da unidade escolar, enquanto instituição social, possibilitando a revisão de seu Projeto Político-Pedagógico; II - realizar análise diagnóstica da turma;

III - discutir o processo pedagógico desenvolvido com as turmas, visando o seu aperfeiçoamento;

IV - analisar o desenvolvimento da aprendizagem dos alunos;

V - acompanhar o desenvolvimento das atividades pedagógicas propostas para potencializar o aproveitamento dos alunos;

VI - verificar a situação de frequência dos alunos, procurando-se estratégias para evitar a evasão e reprovação por esse motivo.

Art. 48. O Conselho de Classe é constituído por:

I - Direção da Unidade Escolar;

II - Equipe Pedagógica;

III - Todos os professores regentes de turma;

IV - Representantes do Conselho Escola Comunidade - CEC;

V - Representantes do Grêmio Estudantil;

Parágrafo único. O Conselho de Classe é autônomo, mas não é soberano.

(Resolução SME $N^{\circ} 1073$ de 14 de Abril de 2010)

Portanto, o COC é responsável, não somente pela decisão conjunta sobre a frequência do aluno, como também pelo seu acompanhamento e pela avaliação de seu aproveitamento. Assim, é nesse momento, que a decisão de comunicar aos pais e aos CTs sobre o absenteísmo dos alunos é tomada. 
Muito se tem discutido a respeito da função dos CTs, apontados como mais uma instância de "encaminhamento" de alunos considerados "problemas”, marcados pela ausência das aulas ou por problemas de outra natureza. Sobre a atuação do Conselho Tutelar, um estudo realizado por Sousa e seus colaboradores (2003) demonstra que:

uma das prerrogativas do ECA refere-se à responsabilidade conjunta da escola e do CT no que se refere às ausências de alunos à escola. A escola deve comunicar ao Conselho Tutelar os casos de crianças que estão faltando muito, fornecendo-lhe nome, série e endereço, para que seus pais sejam notificados, visando saber a razão das faltas. Quando os pais não comparecem ao $\mathrm{CT}$, os conselheiros podem realizar visitas domiciliares, visando esclarecer os motivos. Independentemente de qual seja a razão das faltas, os conselheiros esforçam-se para que a criança ou o jovem volte a frequentar as aulas, conscientizando-o e à sua família sobre a importância da escolarização. Se há algum problema específico com aquela classe ou aquela escola, o conselheiro pode transferir o aluno para outro estabelecimento de ensino (idem, p.73).

Sousa e os demais autores registram a insatisfação dos Conselheiros que reclamam sobre a displicência das escolas, em relação às faltas dos alunos. Segundo os mesmos a escola deveria encaminhar os dados dos alunos que apresentam faltas injustificadas, antes que eles atingissem o limite de vinte e cinco por cento (25\%). De acordo com os Conselheiros esta displicência está relacionada ao sistema de ciclos e à progressão continuada, situações nas quais “o aluno passa sem saber”. Este dado também é evidenciado pelas denúncias que o CT recebe sobre "alunos que frequentam o sexto e o sétimo ano e não sabem escrever” (p.75).

O estudo de Sousa e de seus colaboradores (2003, p.74) analisou $34,8 \%$ (trezentos e setenta e quatro prontuários) do total existente no CT pesquisado, $73 \%$ desses relatavam queixas 
provenientes de pais de alunos e, 27\%, queixas das escolas. Tal fato sugere que a procura dos pais para solucionar os problemas relacionados à escola é três (3) vezes superior ao da escola para resolver os problemas de seus alunos com os pais.

Ao analisar os gráficos subtraídos do estudo de Sousa (idem) visualizamos os motivos das queixas apresentadas aos CTs investigados, o quantitativo das mesmas, os níveis educacionais a que estão relacionadas, as relações de gênero, dentre outros.

Gráfico I - Frequência das demandas escolares no conjunto de prontuários com informações sobre escolaridade (amostra = 130).

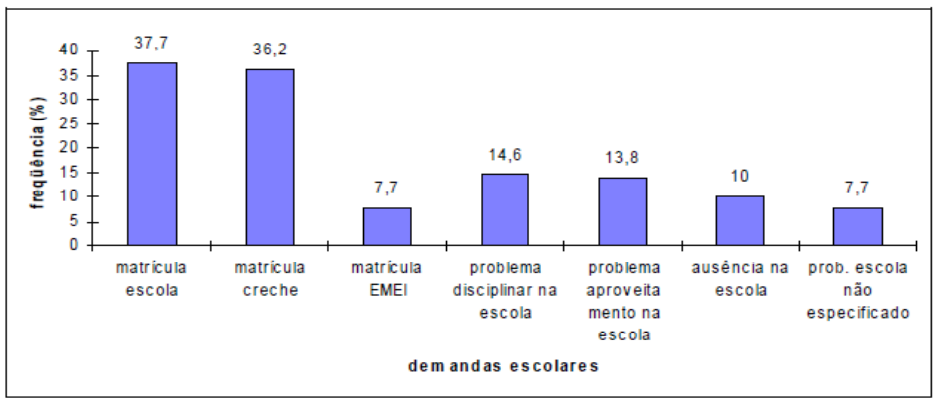

Fonte: Sousa e cols., 2003.

Gráfico II - Frequência de queixas relacionadas a aproveitamento na escola em função do gênero (amostra = 18).

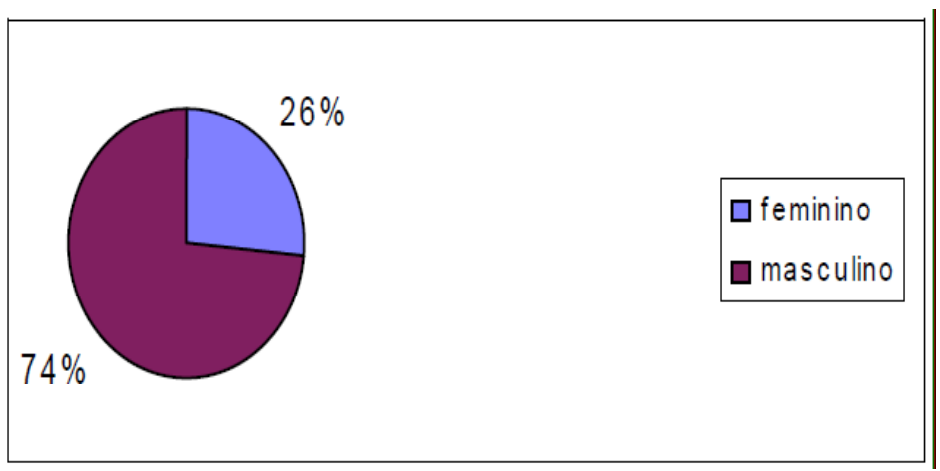

Fonte: Sousa e cols., 2003. 


\section{3}

Gráfico III - Frequência de queixas relacionadas a problemas disciplinares na escola em função do gênero (amostra =19).

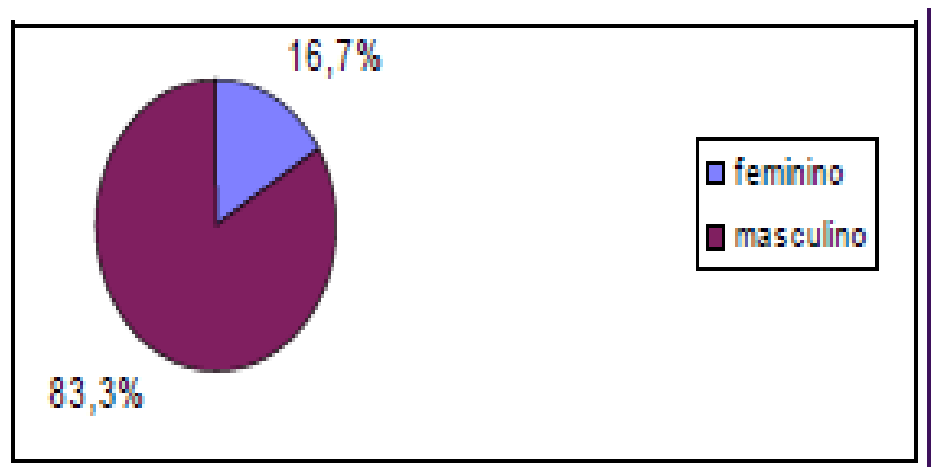

Fonte: Sousa e cols., 2003.

Gráfico IV - Frequência de modalidades de queixas referentes a problemas na escola

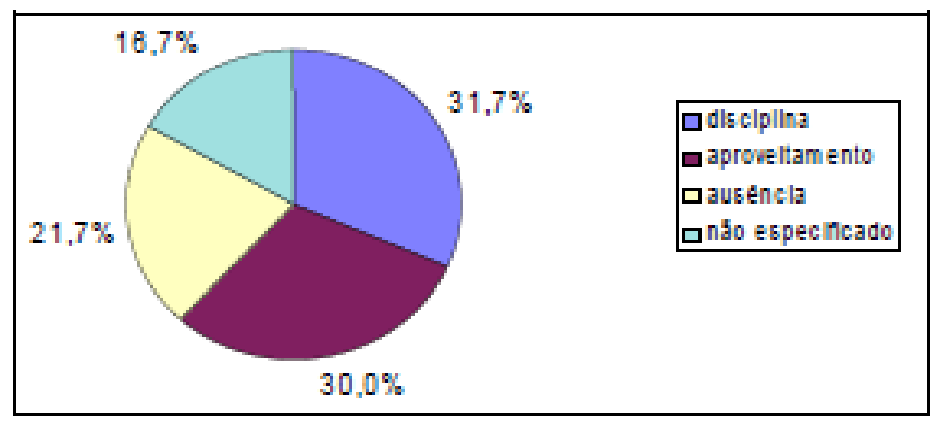

Os dados indicam que as faltas representam 10\% das queixas encaminhadas pelas escolas. As queixas disciplinares representam 14,6\%, do total dos prontuários analisados, deste total, 74\% estão relacionadas aos meninos e, $26 \%$, às meninas. Os problemas com aproveitamento escolar representam 13,8\% das queixas. Os meninos aparecem como responsáveis por $83,3 \%$, enquanto as meninas, por $16,7 \%$.

De um modo geral, no gráfico quatro (4), estão representadas as queixas quanto à disciplina (31,7\%); ao aproveitamento (30,0\%); à ausência (21,7\%) e por razões não especificadas $(16,7 \%)$. 
Estes gráficos demonstram o papel do CT como instância reguladora da escola, dos alunos e dos pais. Entretanto, verificamos em muitos casos que estes CTs também encontram dificuldades em lidar com os problemas que lhes são apresentados. Nas escolas pesquisadas pelo netEDU, alguns alunos referem-se aos membros dos CTs como 'os home', o que significa que têm medo destas pessoas, uma vez que se reportam a elas do mesmo modo que à presença dos policiais em seus locais de moradia (favelas). Nesta pesquisa foram ouvidos ainda diretores e professores, ressaltando a falta de qualificação e representatividade comunitária dos membros destes CTs.

No caso da classe de repetentes da turma C, os professores, em conselhos de classe, geralmente demonstravam preocupação com o excesso de faltas de seus alunos. Uma das professoras comenta:

Eu acho que seria uma responsabilidade muito grande da escola, uma responsabilidade muito grande nossa, né? Aprovar com esse número imenso de faltas.

Durante essas reuniões, a interpretação dos professores sobre o número excedente de faltas dos alunos variou muito. Vários foram os motivos apresentados, entre eles: as relações familiares, a higiene, a saúde e a violência. A família foi mencionada inúmeras vezes como culpada pela ausência do aluno, sendo também responsabilizada por não acompanhar os filhos na escola durante o ano letivo.

As queixas das escolas sobre a falta de envolvimento dos pais nas atividades escolares e nos problemas dos filhos são recorrentes nos estudos sobre a frequência e indisciplina dos alunos. Estas queixas, em sua maioria, refletem a justificativa dos pais sobre os horários disponíveis para este envolvimento, feito que exigiria dos mesmos a ausência ao trabalho.

Os pais, por outro lado, queixam-se das escolas pelo fato de que, quando são chamados, geralmente é para receberem alguma reclamação sobre os filhos. Aos olhos dos pais parece existir uma "soberania do saber escolar", espécie de poder que estaria acima deles e de seus conhecimentos a respeito 
dos filhos (SILVEIRA, 2007, p. 64). Esta soberania revela-se, em especial, através das orientações que a escola oferece à família, a respeito do comportamento das crianças e da ideia de que possuem um saber técnico e profissional sobre a educação da criança. Nesses encontros, chega-se a questionar a natureza das relações conjugais destes pais, muitas vezes interpretadas como fonte para os problemas de seus filhos.

Em sua tese a mesma pesquisadora salienta que, nas relações entre a família e a escola, os bilhetes são a forma mais usual de comunicação e que estes "possuem um caráter 'delator', queixoso e punitivo por parte do professor" (SILVEIRA, 2007, p. 64).

As relações entre a família e a escola foram analisadas por estudos realizados por Viana (2005; 2006; 2007 e 2009) e por Thin (2006): eles indicam que, muitas vezes, a escola da rede pública oferece um contexto social diferente daquele que o aluno vivencia com a família, esta exposição simultânea a culturas divergentes pode gerar uma crise cultural no aluno. Para Viana (2007) as dificuldades vividas pelo aluno podem se desenvolver em dois campos: "aquelas vividas no contexto da experiência escolar e as vividas no bojo das relações familiares" (p. 55). A autora acrescenta que o aluno pode autodeterminar o investimento que faz em sua escolaridade, quase sempre, contando com a colaboração dos familiares, pessoas que "participam da construção do sucesso escolar dos filhos de modo diferenciado, nem sempre facilmente visível e voltado explícita e objetivamente para tal fim" (VIANA, 2007, p. 58).

Além disso, o aluno também conta com a participação da escola para a construção do seu conhecimento. Viana (2006) explica que as três esferas: família, aluno e escola são diferenciadas e interdependentes, e podem contribuir para o sucesso escolar do aluno. Neste tópico, acrescenta-se a autoculpabização dos alunos e de seus pais sobre os seus resultados. Em relatório, Sousa e seus companheiros de pesquisa (2004 p. 36) explicam,

em síntese, as pesquisas que realizaram estudos de caso revelam a dificuldade dos professores para re-significar a avaliação da aprendizagem, mantendo como suas 
principais finalidades decidir quanto à aprovação dos alunos ao término dos ciclos e definir quais deles deverão fazer a recuperação paralela e de férias. A manutenção, na prática, do caráter punitivo e classificatório da avaliação, também se evidencia nas manifestações de alunos. A partir de entrevistas com alunos da rede estadual, Arcas (2003) assinala que estes se posicionam como responsáveis pelos resultados que obtêm na escola, considerando as eventuais notas baixas como decorrência do fato de que não estudaram ou do acompanhamento não satisfatório de sua trajetória escolar por parte da família (SOUSA, 2004 p. 36).

Um estudo de Ireland (2007) apresenta os casos de doença e as chuvas como às justificativas mais usadas pelos alunos e por seus pais para explicar as faltas à escola. Ao lado delas aparecem também: as questões familiares, a falta dos docentes e 0 trabalho doméstico que realizam. Percebemos, com isso, que os motivos são variados para justificar as faltas dos alunos. A análise realizada por este estudo acrescenta ainda que a falta dos alunos é justificada, por parte dos professores, por razões que passam pelas questões familiares, de higiene, de saúde e de violência.

\section{Justificativas e indicadores para o absenteísmo entre os alunos e alunas: evidências da pesquisa da pesquisa de campo realizada}

Mediante a fala dos sujeitos da pesquisa foi possível perceber que a família era constantemente responsabilizada pelos professores e dirigentes pelo baixo desempenho dos alunos, assim como pelas faltas às aulas. Em entrevista, a professora Carla afirma que são poucos os pais que demonstram interesse pelo desempenho escolar dos filhos, visto que muitos deles apresentam problemas sociais.

É... uma outra mãe que vem, que participa da reunião, para a mãe vir até a escola a gente teve que insistir muito ou impedir do aluno vir 
para a escola, são problemas sociais mesmo $e$, ás vezes, assim falta de interesse do pai mesmo, é.. falta de... é... Como é que eu vou dizer? Essa falta de interesse passa pela... falta de instrução dos pais também que é a questão social, né?

...famílias envolvidas com drogas tá, é... [...] crianças que moram com padrasto e é... brigas familiares com a mãe, com o pai, e com o padrasto, é... tem até um caso de prostituição, um caso de prostituição infantil na turma, é... tem casos de higiene seriíssimos, seriíssimos...

A exploração sexual infantil e a saúde, ligada à higiene, também são apontadas como possíveis causas da ausência de uma das alunas, da classe de repetentes da turma C. O nome da aluna (Cláudia, de 11 anos, quatro vezes repetente) foi levado ao COC, considerando o fato de que a mesma possuía noventa e sete (97) faltas. Na ocasião foi sugerido que a aluna buscasse tratamento para alguns problemas de saúde derivados da falta de higiene, tais como: piolho e sarna; motivo de suas faltas, agravadas pela vergonha, uma vez que foi obrigada pela família a cortar o cabelo muito curto, contribuindo com isso para que ela perdesse o interesse de voltar para escola.

De acordo com a professora Sônia, foi necessário ir à casa da aluna, conversar com a avó da menina, para que a mesma retornasse às aulas. A conversa sobre o tema foi a seguinte:

Eu fui buscar ela em casa, porque a escola sugeriu que ela ficasse em casa pra tratar do piolho e da sarna e não voltou nunca mais, tanto que deu 97 faltas e eu fui até a casa dela pra saber se ela tinha morrido né? Aí cheguei lá, conversei com a avó, falei, falei, falei, desde então, ela não faltou nunca mais.

Ela teve sarna e ela teve, não justifica as 97 ta, mas ela teve sarna e ela teve piolho. E nós sugerimos, foi até uma das falas na casa dela, ... mas não fomos nós que não deixamos ela ir na escola, foi a escola que sugeriu..., aí eu 
falei: 47 dias? Porque aí não é possível, ela tem um histórico também, eu já fui preparada pra isso. Mas a justificativa é que, não temos como atestar, eu não sei se isso serve também pra justificar, mas ela teve sarna e piolho e precisou ficar em casa pra se tratar, tanto que ela raspou a cabeça.

Evocê sabe também por que ela não está vindo, porque ela não tratou o piolho, ela raspou a cabeça, tanto que eu comprei umas xuxinhas pra ela, ela falou: tia, tá ridículo!, ela fica com aquela touca, eu falei: Larissa, pelo amor de Deus, larga essa touca, olha o cheiro.

Cláudia que ficou afastada é [...] ficou afastada da escola para tratar a sarna, que ela estava com sarna e com piolho, né! Teve até que raspar a cabeça, e está usando touca o tempo inteiro.

Mariane, uma aluna de nove anos de idade, da classe da turma $\mathrm{C}$, questionada se tinha problemas com faltas, respondeu sucintamente que não, passando a falar do caso da colega de turma. Ela disse "Não, quem falta muito é a Claúdia. [...] Ela tava com piolho, ela raspou a cabeça, por isso que ela fica com a touca. Vê só aquele negócio de chamada tem muita falta dela..."

Ao caso da menina Cláudia, a professora Cássia acrescenta o fato de que a mãe da aluna tem um histórico de surtos e responsabiliza a avó da menina pelos problemas da mesma. No mesmo encontro outras professoras mencionam a família de Cláudia, acrescentando que têm conhecimento de que a menina tem sido forçada pela família a se prostituir. A conversa foi a seguinte:

Ah, ela tem uma história. Em 2005: Crianças afastadas da escola por motivos de problemas familiares. Mãe apresentou surto psicótico pedindo a saída das crianças. As crianças estão com a avó (em 2005). Crianças estão sem uniforme porque a mãe rasgou o uniforme. [...] A mãe dela também tem um problema muito sério de.... de... é problemas neurológicos, 
ela surta de vez em quando né? E.... isso tudo afeta com certeza, com certeza, eu acho que isso né? Não tem dúvida. [...] Essa família, ela é completamente largada, jogada, a mãe não sabe nada, a avó não tem nenhum interesse, e eu não sei... [...] Fica eu e o pedreiro dali, a gente fica só olhando, é um velho de bicicleta que a mãe da Cláudia vai, pega o dinheiro com ele, aí essa semana eles estavam discutindo aqui na esquina porque o velho não queria dar o dinheiro, aí o vizinho também da frente está achando que esse senhor... ela tá usando a filha entendeu?Está vendendo. Prostituindo a filha..[... ] Tem até um caso de prostituição, um caso de prostituição infantil na turma.

Apesar dessa situação, a professora Maria defende a ideia de que a menina "tem conteúdo suficiente para ser promovida para a segunda série”. E mesmo com toda a discussão sobre as condições pessoais da vida da menina, termina por aprová-la. Embora a professora tenha sido questionada por alguns professores, com o argumento de que esta talvez não fosse uma “decisão acertada”, pois a família da menina continuaria desinteressada e isso poderia dar continuidade às faltas.

Pode-se inferir que embora existisse a possibilidade de reprovação automática da aluna Cláudia, pelo COC e pela professora Maria, a menina não foi reprovada, o que indica que as formas de avaliação não são pautadas nas regras legais, essas só se aplicam nos casos em que tanto a professora da classe quanto o COC tem intenção de usá-las como justificativa, como poderá ser visto em alguns casos que citaremos a seguir. No caso da classe da turma $\mathrm{C}$, o que contou para a promoção da menina foi o fato de que a mesma provavelmente dominava a leitura e a escrita, saindo-se melhor que os demais alunos. Portanto, neste caso, o mérito acadêmico prevaleceu.

As violências físicas e verbais na sala de aula contribuem, sobremaneira, para o absenteísmo entre os alunos. A aluna Amanda, de nove (9) anos de idade, foi um desses casos evidenciados na classe da turma $C$, no qual a violência motivou 0 desinteresse pela escola, resultando em cinquenta e dois (52) 
dias letivos de faltas. O nome de Amanda foi citado no COC, uma vez que se deveria decidir sobre o seu destino acadêmico, visto que a mesma ultrapassara o limite de $25 \%$ de faltas. A conversa no COC foi a seguinte: "Amanda, ela está com 52 faltas, mas ela... Ela lê, entende, ela escreve sobre sequência lógica”.

Durante o COC não foi mencionado o motivo do absenteísmo da Amanda, mas em entrevista ela justificou que os colegas batiam nela e a ameaçavam. A conversa com Amanda obteve as seguintes respostas:

É muito difícil. Minha mãe fala quando eu venho pra escola, que é pra eu não brigar. E eu não brigo. Porque senão outros podem me bater. [ mas] Pararam já. Quem batia era o João, Lúcio, Alexandre, Sandro. Só porque naquele dia sem querer, eu entornei um copo e molhei o celular da tia, eles estavam querendo me bater na rua. Saí correndo pra casa, porque eles falaram que iam me pegar.

Ao relacionar as faltas com a violência que sofre, a menina disse:

Eu faltava muito, mas agora eu tô vindo todo dia. Eu não gostava de vir pra escola não. Não gostava não, era muito ruim. Porque os garotos estavam querendo me bater, e minha mãe não mandava eu vir pra escola. Só às vezes quando os meninos não estavam na escola, ela mandava eu vir.

Da mesma forma que no caso anterior, as faltas de Amanda foram 'relevadas'; tanto pela professora Maria quanto pelo COC. Ela foi aprovada, apesar das considerações feitas pelas professoras sobre o caso da menina. A argumentação do COC foi a seguinte:

Gente, a mesma frequência do ano passado, ano passado ela foi reprovada porque tinha 51 faltas, $74 \%$. Mas aí também não foi só isso. Apresenta extrema dificuldade com a leitura, então não foi só por frequência, ela faz atendimento? [... ] Não, ô Cássia, Roberta irmã dela 
também foi reprovada por frequência, Roberta é irmã dela, foi reprovada por freqüência, e ela também tem problema de frequência. [...] 2004 ela foi reprovada na nível um, por frequência. Quando chegou em 2005 ela foi aprovada. Em 2006 ela foi reprovada, não por frequência, ela teve $75 \%$, mas ela foi reprovada por conteúdo, então esse ano já é o terceiro de escolaridade. $E$ aí ano passado ela ficou por frequência e... [...] Agora eu vou ficar mais com a fala da Professora Maria de que ela quer melhorar. Depois da conversa que você teve com ela, ela evita de faltar não é? É. Podia dar uma chance! Você acha que ela tem condições? Tem. Porque ela... leu razoavelmente bem... É, então... E ela tá com 52 faltas é muito pouco, ainda mais no histórico que ela tem.

Constatamos que a menina foi aprovada por ter ultrapassado o limite por "poucas" faltas, apenas cinquenta e duas (52). Vale a pena questionar o que pode ser considerado muito ou pouco, quando temos um mínimo a ser cumprido, ou descumprido, no caso das duas meninas mencionadas anteriormente, Cláudia e Amanda.

Alexandro, menino de dez (10) anos, assim como as alunas anteriores, foi mencionado no COC por ter faltado cinquenta e seis (56) dias letivos durante o ano. Neste caso, o número de faltas, contrário aos outros citados, foi considerado muito elevado. O motivo levantado pelo COC foi a indisciplina do aluno, em sala de aula, assim como a sua origem familiar, pois as professoras argumentaram que a convivência com uma família 'violenta' era responsável pelo mal comportamento do menino. A conversa sobre o caso de Alexandro pode ser transcrita assim:

Alexandro. Também tem 10 anos. É repetente. Ele está com 56 faltas, e ele vem pra escola, faz o que quer, e ele não aceita ser contrariado, bate na cadeira, se joga no chão. E ele lê? Ele lê, mas na hora de escrever... por exemplo, "balão" ele já escreve. Se falar bem pausado né. É, bem pausado. Também o que? Tem 11 anos! 10 ! E é o segundo ano dele, ta no segundo ano 
de escolaridade... Chato que já tem sérios problemas né. É. Quem é favorável à reprovação do Alexandre? (Todos os presentes levantam as mãos) [...] Com toda essa problemática familiar dele também. É, mudança também de... Pois é, e esses hábitos adquiridos que ele está né? De todo esse histórico está bastante... não, como vai ser ano que vem, não.

Em entrevista, as professoras relataram assim o caso de Alexandro:

A questão do Alexandro, o Alexandro na verdade perdeu mais por frequência né? Ele foi retido por frequência pela dificuldade dele, ele até sabe ler, sabe escrever, não está ainda, é vamos dizer assim é... como aluno de terceiro ano que é pra onde ele iria, mas a dificuldade no Alexandre, essa reprovação dele foi mais proveniente das faltas dele tá?”

"O Alexandro, ele é vive em um ambiente de... é... de drogas e é... roubo é...vive também a mãe com o padrasto, e a mãe esteve essa semana aqui na escola e disse que o pai ameaçou de matá-la com facas e ele com o irmão menor é que foram chamar a polícia. Acredito que todo esse é envolvimento familiar, essa... não ter um ambiente é... um ambiente tranqüilo não é, é.. isso faz com que o seu... e com certeza também ele apresenta algumas questões neurológicas que nós já.. já é... solicitamos que fizesse os exames e ela até hoje não fez né? E o papel da escola assim está sendo feito, tudo registrado, tudo assinado pela mãe também, todas as questões, é... o Alexandre já apareceu na escola com alguns objetos que foram roubados, nós solicitamos a presença da mãe e devolvemos nas mãos da mãe, acredito que tudo isso é...

Alexandro, entretanto, tem outra versão para o absenteísmo nas aulas da professora Maria. Em entrevista, tanto ele como seu colega de classe, Felipe, afirmaram muitas vezes que 
faltaram as aulas por conta do absenteísmo da professora. A fala dos meninos pode ser transcrita assim:

Ontem eu faltei porque eu fui pra minha tia e não trouxe meu material porque não tinha aula. Alexandro: A tia faltou. (Todos foram foi embora?) Sim. (tem outra professora para substituir?) Não. (Felipe tem alguma coisa que você gosta na professora?) Tem, porque ela falta aula. Às vezes.

Observamos nas discussões do COC que somente o absenteísmo dos alunos é levado em conta, a falta das professoras não foi mencionada. No caso do Alexandro, o que contou para a sua reprovação foi a associação de dois fatores: a indisciplina em sala de aula e o histórico familiar. Sobre problemas familiares, muitos casos foram mencionados no COC. Em entrevista, uma professora resume a percepção do grupo sobre o tema:

a maioria dos pais não tem interesse em acompanhar o desenvolvimento dos filhos. Acho que também tem, tem essa coisa da família, da família em casa procurar: meu filho tem algum dever de casa? Vamos sentar, vamos ver, vamos ler. Eu acho que esse apoio eles não tem em casa, a maioria, a maioria.

Ficou evidente nas análises derivadas desta pesquisa, no que tange ao absenteísmo escolar, que os estudos apresentados, de fato, puderam ser comprovados; pois as justificativas mais comuns para o absenteísmo foram: a pobreza, associada à falta de saúde e às questões de higiene e à violência aos problemas familiares.

Entretanto, apesar de existirem regras definidas, leis e órgãos reguladores sobre o absenteísmo escolar, as análises realizadas revelam que estes não são considerados. A "autonomia relativa dos COCs”, prevista no regimento escolar, foi transformada, nos casos analisados, em “ lei da escola”, uma vez que a soberania da decisão fica nas mãos dos professores, que justificam através do COC, com os mesmos argumentos legais, decisões diferentes. O caso desta escola assemelha-se 
muito às decisões judiciárias no Brasil, pois para quem tem capital econômico a lei é uma e para os pobres e desvalidos, a lei é outra. Tudo depende da vontade do poder público de gerenciar com 'justiça' e 'isenção' o caso que tem em mãos.

No presente capítulo, observamos que por conta de uma lei determinada pelo MEC, os alunos que não cumprirem $75 \%$ de frequência devem ser automaticamente reprovados. Entretanto, na classe de repetentes da turma C, a quantidade de faltas não é um fator que pode levar à reprovação, considerando que alunos com alto índice de absenteísmo foram considerados aptos ou inaptos para a série seguinte, tendo sido avaliados de formas diferentes pelo conselho de classe da Escola João Pedro II. Os critérios utilizados para a aprovação e/ ou reprovação não foram explicitados durante o conselho de classe, por isso, a pesquisadora não pôde definir claramente quais foram os critérios usados para aprovar ou reprovar um aluno, com um alto índice de faltas. 


\section{Referências}

BRASIL. Lei no 9.394. Estabelece as Diretrizes e Bases da Educação Nacional, de 20 de dezembro de 1996. Presidência da República. Brasília, DF

BRASIL. Constituição da República Federativa do Brasil. Presidência da República. 5 de outubro de 1988. Brasília, DF

BRASIL. Estatuto da Criança e do Adolescente, Câmera dos Deputados, Lei no 8.069, de 13 de julho de 1990. DOU de 16/07/1990 - ECA. Brasília, DF.

CANDAU, V. M. Direitos humanos, educação e interculturalidade: as tensões entre igualdade e diferença. In: Revista Brasileira de Educação, v. 13, n. 37, p. 45-56, 2008.

CHOUQUET, M.; HASSLER, C. Absentéisme au Lycée. Les dossier D'Education et Formations. Ministère de l'Éducation Nationale, de La Recherche et de la Technologie. Paris, France: 1993

FLETCHER, R.P., RIBEIRO, S.C. A educação na estatística nacional. In: SAWYER, D. O. (org.). PNADs em foco: anos 80. Belo Horizonte, Associação Brasileira de Estudos Populacionais - ABEP.

Galloway, D.; Seyd, R.; Ball, T. Absence from school and behavior problems in school therapeutic education. London: Pergamon Press, 1978.

GOUVÊA, G. F. P. Um Salto para o presente: a educação básica no Brasil. São Paulo em Perspectiva, v.14, n.1, 2000.

IRELAND, V. E. (coord.); CHARLOT, B.; GOMES, C.; GUSSO, D.; CARVALHO, L. C. R. de; FERNANDES, M; ENNAFAA, R.; GARCIA, W. Repensando a escola: um estudo sobre os desafios de aprender, ler e escrever. Brasília: UNESCO, MEC/INEP, 2007.

KAFURI, R.; RAMON, S. P. Pesquisa sobre evasão, repetência e fatores condicionantes: relatório $-1^{\circ}$ grau, casos e percalços. Goiânia: UFG: FAE, 1985. 
MAINARDES, J. Organização da escolaridade em ciclos no Brasil: revisão da literatura e perspectivas para a pesquisa. Educação e Pesquisa. São Paulo, v. 32, n. 1, p. 1129, jan./abr. 2006.

NERI, M. C.; COSTA, D. R. da. O Tempo das crianças. Rio de Janeiro: Fundação Getúlio Vargas, 2002 (Ensaios Econômicos, 468).

PAZELLO, E.T.; FERNANDES, R.; FELICIO, F. Incorporando o atraso escolar e as características sócio-demográficas nas taxas de transição educacional: um modelo de fluxo escolar. Anais do XXXIII Encontro Nacional de Economia, ANPEC, 2005.

REID, K. C. Alienation and persistent school absenteism.

Research in Education, v.29, p.31-40, 1981. 


\section{Autores}

Carmen Lúcia Guimarães de Mattos (Ph D in Education - UPENN) professora adjunta da Faculdade de Educação e do Programa de Pós-Graduação em Educação da Universidade do Estado do Rio de Janeiro e Procientista (SR2). Coordenadora do Núcleo de Etnografia em Educação e da linha de pesquisa Etnografia e Exclusão. Desenvolve estudos em etnografia, exclusão, gênero, pobreza e violência.

Paula Almeida de Castro (Doutora em Educação - ProPEd/ UERJ), professora da Faculdade de Formação do Professores da Universidade do Estado do Rio de Janeiro. Subcoordenadora do Núcleo de Etnografia em Educação. Pesquisadora associada do grupo de pesquisa Etnografia e Exclusão. Desenvolve estudos na área de etnografia, pertencimento e resiliência, processos de tornar-se aluno.

Maria Inês de Matos Coelho (Doutora em Educação-UFRJ), realizou estágio de pós-doutorado com Carmen de Mattos em 2008 pelo ProPEd/UERJ. Professora Emérita da Universidade do Estado de Minas Gerais e Consultora do Programa das Nações Unidas para o Desenvolvimento (PNUD).

Sandra Maciel de Almeida (Doutoranda em Educação - ProPEd/UERJ), professora da Faculdade de Educação da Universidade do Estado do Rio de Janeiro. Pesquisadora associada do Núcleo de Etnografia em Educação e do grupo de pesquisa Etnografia e Exclusão. Desenvolve estudos na área de educação de jovens e mulheres em situação de privação de liberdade. 
Tatiana Bezerra Fagundes (Mestre em Educação ProPEd/UERJ) professora da Secretaria Municipal de Educação do Rio de Janeiro e do Colégio de Aplicação da Universidade do Estado do Rio de Janeiro. Pesquisadora em Formação Básica do grupo de pesquisa Linguagem, Cognição Humana e Processos educacionais.

Daiane de Macedo Costa (Mestranda em Educação ProPEd/UERJ), pesquisadora associada do Núcleo de Etnografia em Educação. Desenvolve seus estudos sobre interações escolares.

Adriana Maria Ribeiro Gil Ferreira (Mestre em Educação - PUC/Rio), participou do grupo de pesquisa do Núcleo de Etnografia em Educação como bolsista de Iniciação à Docência (Cetreina/UERJ).

Suziane Santana Vasconcellos (Mestre em Educação ProPEd/UERJ), professora da Faculdade de Educação da Universidade do Estado do Rio de Janeiro. Pesquisadora associada do Núcleo de Etnografia em Educação e do grupo de pesquisa Etnografia e Exclusão. 




\section{LIVROS EDUEPB E LATUS}

1. Pluralismo Jurídico: Para além da visão monista - Raíssa de Lima e Melo

2. Mulher, corpo e cuidado - Maria de F. de A. Silveira; e Dulce M. Rosa Gualda

3. Avaliação de serviços: um olhar na qualidade da gestão - (Orgs) Maria José Cariri Benígna; e Maria A. Amado Rivera

4. Farmacêutico na Farmácia - Rosimary S. Cunha Lima; Maria do Carmo Eutálio; e Magnólia de L. S. Targino

5. Representações sociais e saúde - Aliana Fenandes; Maria. do R de Carvalho; e Moisés Domingos Sobrinho

6. EPI Info para iniciantes - (Orgs) Sonia Maria de L. Maciel; e Pedro Henrique de A. e S. Leite

7. Ensino de lingua: do impresso ao virtual - (Orgs) Antonio de Pádua Dias da Silva; Maria de L. L. Almeida; Simone Dália de Gusmão Aranha; e Tereza. N. de Farias Campina

8. A história da mídia regional - C. B de Souza; F. G. de Oliveira; e Gorete M. Sampaio de Freitas

9. Livro de resumo de monografias - Maria Dora Ruiz Temoche

10. Planejamento tributário no campo de incidência do ICMS - Alexandre H. S. Ferreira; e Ana Maria da P. Duarte

11. 1930 - A Revolução que mudou a História do Brasil - (Orgs) João M. L. Santos; Cláudo José L. Rodrigues; Inês Caminha L. Rodrigues; e José Octávio de A. Melo

12. Curso de Direito Constitucional - Lorivaldo da Conceição

13. Fragmentos - Juarez Filgueras de Góis

14. Gênero em questão - (Org) Antonio de Pádua Dias da Silva

15. Jogos eletrônicos - Eliane de M. Silva; Filomena M. G. da S. C Moita; e Robson Pequeno de Souza

16. Nascido do Fogo, Filho da Paz - Ket Jeffson Vasconcelos Leitão

17. Política Tributária e Justiça Social - Alexandre Henrique Salema Ferreira

18. Revista Sócio-Poética - Departamento de Letras da UEPB

19. O Sábio e a Floresta - Moacir Werneck de Castro

20. Universidade e o fazer poético em prosa e poesia - (Orgs) Fabíola Nóbrega; Marcelle V. Carvalho; e Tatiana Fernandes Sant'ana

21. Sustentabilidade - um enfoque sistêmico - (Orgs) Waleska S. Lira; Helio de L. Lira; Maria José dos Santos; e Lincon Eloy de Araújo

22. Bioquímica clínica - uma abordagem geral - Sandra Reis Farias

23. Mortalidade Geral - Epidemologia - Anthonyanny A. Silva Lima; Maria J. Cariri Benigna

24. Estudos Filológicos: Literatura - Cultura - Marinalva Freire da Silva

25. Dicionário de termos relativos a gestão de pessoas - Maria Dora Ruiz Temoche 
26. Práticas de Políticas Públicas - (Orgs) Marcelo A. Pereira; Maria da G. A. Pereira; Sandra. M. A de S. Celestino; Sueli Ramos de R. M. Cavalcanti; e Wíliam A. de Lacerda

27. Saúde Humana - (Org) Inácia Sátiro Xavier de França

28. O Segredo de Pergamo - Ket Jeffson Vasconcelos Leitão

29. A queda do meteorito - Giusone Ferreira Rodrigues

30. Trajetória empreendedora: estudo de casos numa realidade local e global - (Org) Vera Lúcia Barreto Motta

31. Identidades de gênero e práticas discursivas - (Org) Antonio de Pádua Dias da Silva

32. O lugar da Educação Física - Maria José de Figueirêdo Gomes

33. O papel político dos fóruns de educação de jovens e adultos - Eduardo Jorge Lopes da Silva

34. Pesquisa histórica - resumo de monografias - (Orgs) Luíra Freire Monteiro; e Flávio Carreiro de Santana

35. Anos de luta - Waldir Porfírio

36. Mulher e violência: histórias do corpo negado - Lígia Pereira dos Santos

37. Agricultura orgânica - José Geraldo R. dos Santos; e Emmanuelly Calina X. R. Santos

38. Sobre o diálogo: introdução a uma leitura filosófica de - Julio Cesar Kestering

39. Novos cenários da Administração - (Org) maria Dora Ruiz Temoche

40. 0 despertar da cultura - (Org) Marinalva Freire da Silva

41. Manual básico de Radiologia Odontológica - Maria de Fátima Cavalcanti Rodrigues

42. Formas de sociabilidade e instauração da alteridade - Inácia S. Xavier de França; Lorita M. Freitag Paghuca

43. Paremiologia nordestina - Fontes Ibiapina

44. Resistência indígena no Piauí colonial 1718 - 1774 - João Renor F. de Carvalho

45. Planejando o (des)envolvimento local - Roberto Alves de Araújo; e Ana Siqueira de Araújo

46. Deuses em poéticas: estudos de Literatura e Teologia - (Orgs) Salma Farraz; Antonio Magalhães; Eli Brandão; Waldecy Tenório; Douglas Conceição

47. Campina Grande em debate - (Org) Roberto Véras de Oliveira

48. História do Direito e da violência: recortes de uma abordagem interdisciplinar - Marcelo Alves Pereira Eufrásio

49. Contos jurídicos: normas de sobredireito da Lei de Introdução ao Código Civil - Ket Jeffson Vasconcelos Leitão

50. A Bacia do Rio Gramame: Biodiversidade, uso e conservação (Orgs) José Etam de Lucena Barbosa; e Takako Watanabe; e R. José da Paz

51. Ser criança - repensando o lugar da criança na educação infantil (Orgs) Glória M. de Souza Melo; Soraya. M. de A. Brandão; e Marinalva. da Silva Mota 
52. Estudos Sociais da Ciência e Tecnologia - (Org) Renato Dagnino

53. De portas abertas para o lazer - (Orgs) Elaine Melo de B. Costa Lemos; Eduardo Ribeiro Dantas; e Cheng Hzin Nery Chão

54. Gênero e práticas culturais - (Orgs) Charliton J. dos Santos Machado; Idalina M. F. Lima Santiago; e Maria L. da Silva Nunes

55. Da resistência ao poder - o (P)MDB na Paraíba (1965 / 1999) José Otávio de Arruda Mello

56. Políticas públicas e desenvolvimento regional - (Orgs) Carlos. A. Máximo Pimenta; Cecília Pescatore Alves

57. Histórias vividas e contadas no Bar do Brito - (Orgs) A. C. Barbosa de Souza; Antonio Guedes Rangel Junior; Clara M. Araújo Pinto; e Sonia Maria A. de Oliveira Brito

58. De memória e de identidade - (Orgs) Antonia M. M. da Slva; Francisco Paulo da Silva; Ivanaldo Oliveira dos Santos; e Maria Edileuza da Costa

59. A luz que não se apaga - Rômulo de Araújo Lima

60. Cálculo avançado - (Orgs) Aldo Trajano Louredo; e Alexandro M. de Oliveira; e Osmundo Alves Lima

61. Fisioterapia na gravidez - (Org) Maria do Socorro B. e Silva

62. Educação Universitária - Pedro Bergamo

63. Amora - Fidélia Cassandra

64. Educação em questão - recortando temas e tecendo ideias - (Pedro Lúcio Barboza)

65. Ciço de Luzia - Efigênio Moura

66. Zila Mamede - trajetórias literárias e educativas - Charliton José dos Santos Machado

67. A voz da infância e outras vozes - Calos Azevedo

68. A Educação da Mulher em Lima Barreto - (Jomar Ricardo da Silva)

69. Porta aberta à poesia popular - Almira Araújo Cruz Soares

70. Mulheres representadas na literatura de autoria feminina - Antonio de Pádua Dias da Silva

71. Residências terapêuticas - (Orgs) Maria de Fátima de A. Silveira e Hudson Pires de O. Santos Júnior

72. A nuvem de hoje - Braulio Taveres

73. Tecnologias digitais na educação - (Orgs) Robson Pequeno de Sousa; Filomena M. C. da S. C. Moita; e Ana Beatriz Gomes Carvalho.

74. A representação da sogra na obra de Leandro Gomes de Barros José Itamar Sales da Silva

75. Viagem aos 80 anos da Revolta de Princesa - Janduí Dantas

76. Cidadania glocal, identidade nordestina - José Marques de Melo

77. Uma nova ciência para um novo senso comum - Marcelo Germano Gomes

78. A feira - o trovador encantado - Maria de Lourdes Nunes Ramalho

79. Nordeste como inventiva simbólica - Geralda Medeiros Nóbrega

80. Era uma vez diferente - Aline Pereira

81. Colecionismo, práticas de campo e representações - Maria Margaret Lopes e Alda Heizer. 
Sobre o livro

Impressão Gráfica Universitária da UEPB

Formato $16 \times 23 \mathrm{~cm}$.

Mancha Gráfica $11,5 \times 18,5 \mathrm{~cm}$.

Tipologias Droid Serif 11/13

Miolo Papel Apergaminhado $75 \mathrm{~g} / \mathrm{m}^{2}$

Capa Cartão Supremo $250 \mathrm{~g} / \mathrm{m}^{2}$ 